UNIVERSIDADE DE SÃO PAULO

FACULDADE DE FILOSOFIA, LETRAS E CIÊNCIAS HUMANAS

DEPARTAMENTO DE HISTÓRIA

PROGRAMA DE PÓS-GRADUAÇÃO EM HISTÓRIA SOCIAL

\title{
O samba em pessoa: narrativas das Velhas Guardas da Portela e do Império Serrano
}


UNIVERSIDADE DE SÃO PAULO

FACULDADE DE FILOSOFIA, LETRAS E CIÊNCIAS HUMANAS

DEPARTAMENTO DE HISTÓRIA

PROGRAMA DE PÓS-GRADUAÇÃO EM HISTÓRIA SOCIAL

\section{O samba em pessoa: narrativas das Velhas Guardas da Portela e do Império Serrano}

Fernanda Paiva Guimarães

Dissertação apresentada ao Programa de Pós-Graduação em História Social do Departamento de História da Faculdade de Filosofia, Letras e Ciências Humanas da Universidade de São Paulo, para a obtenção do título de Mestre em História Social.

Versão corrigida

Orientador: Prof. Dr. José Carlos Sebe Bom Meihy 


\section{Catalogação na Publicação}

\section{Serviço de Biblioteca e Documentação}

Faculdade de Filosofia, Letras e Ciências Humanas da Universidade de São Paulo

Guimarães, Fernanda Paiva

O samba em pessoa: narrativas das Velhas Guardas da Portela e do Império Serrano. / Fernanda Paiva Guimarães ; orientador José Carlos Sebe Bom Meihy. - São Paulo, 2011.

219 f. : il.

Dissertação (Mestrado) - Faculdade de Filosofia, Letras e Ciências Humanas da Universidade de São Paulo. Departamento de História. Área de concentração: História Social.

1. História oral. 2. Samba. 3. Música popular - Brasil. 4. Memória social - história.

5. Escolas de samba. I. Título. II. Meihy, José Carlos Sebe Bom.

CDD 907.2

780.420981 
GUIMARÃES, Fernanda Paiva

O samba em pessoa: narrativas das Velhas Guardas da Portela e do Império Serrano

Dissertação apresentada ao Programa de Pós-Graduação em História Social do Departamento de História da Faculdade de Filosofia, Letras e Ciências Humanas da Universidade de São Paulo, para a obtenção do título de Mestre em História Social

Aprovado em: 16 de março de 2011

\section{Banca Examinadora}

Prof. Dr. José Carlos Sebe Bom Meihy

Universidade de São Paulo - USP

Prof. Dr. José Geraldo Vinci de Moraes

Universidade de São Paulo - USP

\section{Prof. Dr. Mauricio Barros de Castro}

Universidade do Estado do Rio de Janeiro - UERJ 


\section{AGRADECIMENTOS}

Agradeço, em primeiro lugar, a José Carlos Sebe Bom Meihy, meu orientador, que apostou na entrada deste projeto no Núcleo de Estudos em História Oral - NEHO/USP e acompanhou com atenção o desenvolvimento desta pesquisa.

Carlos Magalhães, Olga Futemma e Patricia de Filippi, diretores da Cinemateca Brasileira, apoiaram a minha presença no mestrado por palavras e por gestos de grande generosidade. Dentre os muitos colegas de trabalho aos quais sou grata, Lígia Farias foi quem me deu fundamental "cobertura" nos últimos meses do mestrado, com um bom humor quase alienígena.

Pela estimulante convivência, agradeço aos colegas do NEHO: Ricardo Santhiago, Maria Aparecida Blaz, Maurício Barros de Castro, Juniele Rabêlo de Almeida, Vanessa Generoso Paes, Cássia Milena Nunes de Oliveira, Marcel Diego Tonini, Marcela Boni Evangelista, Marta Rovai, Eduardo Meinberg, Fabíola Holanda Barbosa e Suzana Lopes Salgado Ribeiro.

Os colegas de Pós-Graduação, especialmente Ricardo Cardim e Rosane Pavam, bem como os Professores José Geraldo Vinci de Moraes, Elias Thomé Saliba e Sara Albieri, contribuíram para meu movimento de retomada dos estudos, no decorrer das disciplinas. Pelas importantes sugestões durante o exame de qualificação, agradeço aos Professores José Geraldo e Marcos Napolitano.

Miguel Soares Palmeira, meu lugar no mundo, com paciência e grandeza foi meu interlocutor constante e ajudou até quando não sabia que estava ajudando.

Meus pais, Roberto e Angela, e meus irmãos, Rodrigo e Juliana, estão em tudo que faço. José Guerra Neto chegou depois, mas assumiu com desembaraço uma posição de destaque no meu panteão de pessoas mais importantes do mundo. Daltony Nóbrega e Bia Peine, meu casal preferido de crianças em corpo de adulto, me encheram de música, humor e chocolate. Rita Palmeira e Flávio Moura, vizinhos “à moda antiga", são presença marcante, afetiva e intelectualmente.

Maria Izaias Guedes talvez seja a razão principal do meu interesse por cultura popular. Registro aqui o meu carinho e um especial agradecimento. A ela devo uma vida de trabalho.

Eduardo Gallotti, Aluízio Maranhão e Tutu têm grande influência no meu repertório musical. Deixo um agradecimento pelas muitas noites de samba que me enchem de alegria.

Contei, ao longo da pesquisa, com a ajuda dos "guias" Eli Briareu e Jorge Luiz Amaral (Doutor Bigu), que literalmente abriram caminhos para a pesquisa. Angela Paiva, Augusto Lima, Elielma Ayres, Fernando Paulino, Nely Silveira, Simone Dubeux e Roberto Guimarães ajudaram com indicações ou com os ouvidos. Agradeço a Carlos Monte pela esclarecedora entrevista e a Áurea Maria, Balbina, Ivan Milanez, Jussara, Lindomar, Monarco, Noca da Portela, Serginho Procópio, Surica, Wilson das Neves, Zé Katimba e Zé Luiz do Império Serrano pelas histórias de vida. Espero honrar o tempo e as palavras que me emprestaram. 


\section{RESUMO:}

A presente dissertação trata das narrativas de experiências pessoais de "velhos sambistas". O corpus documental é constituído de sambas e narrativas feitos por participantes dos conjuntos musicais chamados Velha Guarda da Portela e Velha Guarda do Império Serrano. As histórias de vida de sambistas e pastoras, produzidas adotando os procedimentos da história oral, expõem temas polêmicos afeitos à tradição e à modernização dos desfiles. Sambas gravados por essas duas "Velhas Guardas" funcionam como apoio e complemento, tomados como documentos que permitem acessar o discurso mnemônico vinculado a um discurso dominante sobre o samba no contexto cultural carioca dos anos 2000. A partir das vivências e das visões dessas pessoas sobre a "evolução" das escolas de samba, procura-se entender o papel dos grupos aos quais pertencem, localizados simbolicamente entre as "raízes" e os desafios da atualização das agremiações carnavalescas.

Palavras-chave: Samba, Velha Guarda, História Oral, Memória, Música popular brasileira.

\section{ABSTRACT:}

This dissertation deals with personal experiences narrated by "old sambistas". Its document corpus consists of sambas and narratives made by participants in musical ensembles called Velha Guarda da Portela and Velha Guarda do Império Serrano. The life stories of samba men and women, which were produced following oral history procedures, expose controversial issues that relate to the tradition and modernization of samba school parades. The songs that were recorded by those two samba "Old Guards" are regarded as complementary documents, that allow access to a mnemonic speech linked to a dominant discourse about samba in Rio de Janeiro's cultural context of the 2000s. By observing the life experiences and visions of those people about the "evolution" of samba schools, the purpose is to understand the role of the groups to which they belong, symbolically positioned between the "roots" and the challenges of the adjustment of carnival groups to new times.

Key-words: Samba, Old Guard, Oral History, Memory, Brazilian popular music. 


\section{SUMÁRIO}

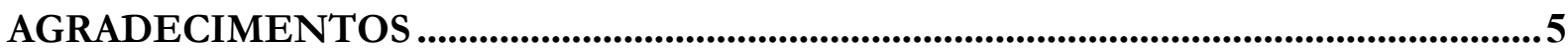

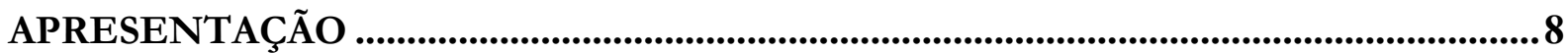

PARTE I

1. Histórico e procedimentos de pesquisa ....................................................................14

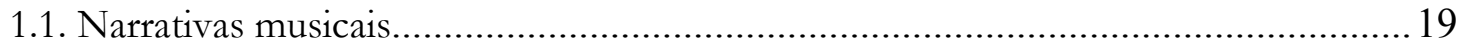

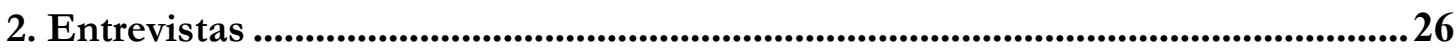

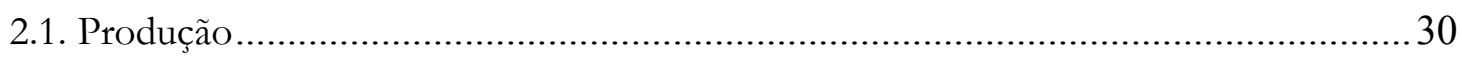

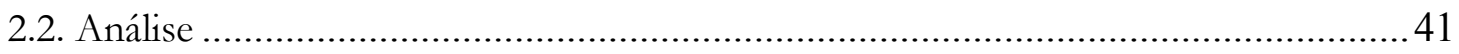

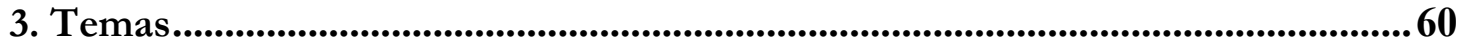

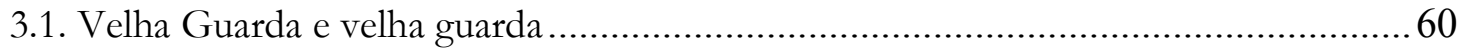

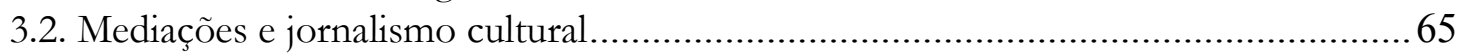

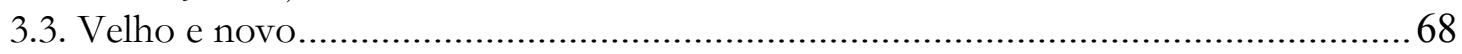

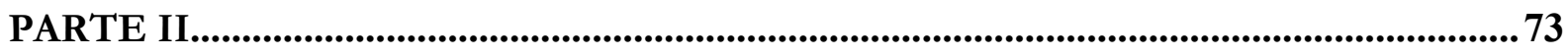

MONARCO

"O meu samba não tem agrotóxico, é um samba tirado do coração" .............................................75

SERGINHO PROCÓPIO

"A Velha Guarda é maior que a gente. Temos a responsabilidade de guardar os sambas dos antigos" 88 TIA SURICA

"Eu gosto é de ser independente".

ÁUREA MARIA

"Só tenho a aprender a cada dia".

WILSON DAS NEVES

"Vocêpode melhorar aquilo que está fazendo sem deturpar, como diž o Paulinho da Viola - não me mexe no samba tanto assim, né?"......

IVAN MILANEZ

"Agora quem vai falar de mim sou eu".

LINDOMAR

"Quero ter tempo para curtir mais a vida".

BALBINA

"Viver, você dá o teu exemplo. Se eles não quiserem, o problema é deles"..................................... 146

ZÉ LUIZ DO IMPÉRIO SERRANO

"Eu sempre tive essa atitude, ninguém vai me prender aqui"................................................. 170

NOCA DA PORTELA

"Os sambistas precisam de escola. A escola precisa de sambistas".

ZÉ KATIMBA

"Sou vitorioso, graças a Deus, ao samba e à mulher".

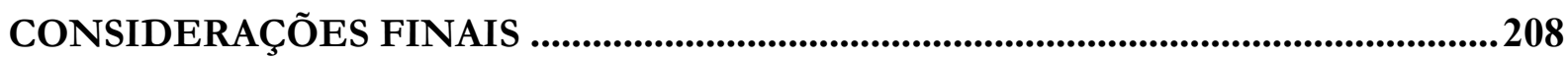

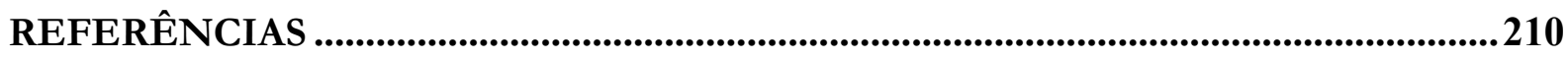

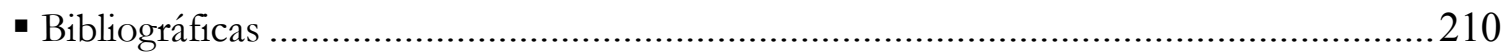

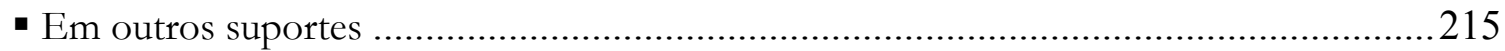

ANEXO - Vozes registradas (roteiro para escutas) ......................................................................218 


\title{
APRESENTAÇÃO
}

\author{
Sou velha guarda \\ Já provei pro mundo inteiro que sou bamba \\ Sou velha guarda \\ A espinha dorsal do samba \\ Fui mestre-sala, diretor e ritmista \\ Já puxei corda pra desimpedir a pista \\ Já corri da polícia, sem ser marginal \\ Já esquentei surdo com folha de jornal \\ E apesar de tudo eu estou numa boa \\ $A$ velha guarda é o samba em pessoa \\ Já fui carpinteiro, serralheiro e artesão \\ Até a minha casa já serviu de barracão \\ Já dei muito tapa em otário vacilão \\ Só pra defender meu pavilhão \\ Já namorei passista, mulata e porta-bandeira \\ Fui apaixonado por baiana e costureira \\ E essa juventude que começa a desfilar \\ Será a velha guarda de amanhã \\ Dicró e Pongá, Velha Guarda. [faixa 1 do CD anexo]
}

Na madrugada do dia 7 de fevereiro de 2005, no Rio de Janeiro, pela primeira vez na história do Grêmio Recreativo Escola de Samba Portela, a velha guarda deixou de desfilar com a escola, em função do tempo que deveria ser cumprido para que o Sambódromo - como é conhecida a Passarela Professor Darcy Ribeiro, na Avenida Marquês de Sapucaí - fosse percorrido. Além disso, houvera um incêndio no carro abre-alas no dia anterior e a águia, símbolo da escola, entrara na avenida sem as asas, por problemas com a remontagem depois do fogo. Apesar de não ter encerrado a apresentação da Portela, a velha guarda foi muito aplaudida ao percorrer a passarela em seguida ao desfile da escola cantando, sem o acompanhamento da bateria, o samba-enredo Nós podemos: oito idéias para mudar o mundo, daquele ano. Depois de a Liga Independente das Escolas de Samba do Rio de Janeiro (LIESA) cogitar fazer um desfile inteiro para a velha guarda da Portela no desfile das campeãs, a Beija-Flor de Nilópolis, vencedora da competição, convidou-a para desfilar junto à sua própria velha guarda ${ }^{1}$.

\footnotetext{
${ }^{1}$ A Beija-Flor é afilhada da Portela, com quem compartilha as cores azul e branco. Ver, a respeito da situação da velha guarda da Portela, registros de notícias veiculadas pelos telejornais da Rede Globo: no dia 8 de fevereiro de 2005, foram ao ar as matérias "Tristeza em Madureira", no RJTV 1ª edição, "Velha Guarda de luto", no RJTV 2a edição, "Tristeza e decepção", no Jornal Nacional e "De cortar o coração", no Jornal da Globo; no dia 9
} 
O desfile da Portela de 2005 pode ser considerado simbólico sob diversos aspectos. O mais evidente deles é que a velha guarda - departamento composto por integrantes mais antigos, que ajudaram a fazer os carnavais pregressos da escola - foi deixada de fora do momento mais importante do calendário anual das escolas de samba cariocas na atualidade, por uma questão de agilidade. Caso a velha guarda entrasse na avenida, a escola perderia pontos, porque seria ultrapassado o tempo regulamentar, de 65 a 80 minutos. A Portela ficou em $13^{\circ}$ lugar - duas posições acima do rebaixamento - e, apesar do desgosto inicial, integrantes da velha guarda ponderaram ${ }^{2}$ que, naquelas condições, a exclusão evitou que escola deixasse, pela primeira vez, o Grupo Especial ${ }^{3}$. A imagem da águia do abre-alas sem as asas é igualmente digna de registro: ao ser idealizado, em 1926, por Antonio Caetano, o símbolo da escola expressava o mais alto vôo.

É curioso observar que, como para encerrar o episódio de cinco anos antes, em 2010, a Velha Guarda da Portela ${ }^{4}$ desfilou junto com a águia no carro abre-alas ${ }^{5}$. O prejuízo à velha guarda no desfile de 2005 pode ser lido como sintoma das mudanças nos desfiles de escolas de samba a partir da década de 1950, quando passaram a gerar receitas cada vez mais volumosas e pessoas "estranhas" às comunidades começaram a se envolver no desfile ${ }^{6}$. Essas mudanças são amplamente discutidas por aqueles que acompanham, academicamente ou não, o samba e o carnaval carioca ao longo do tempo. Mas cabe também notar que o episódio gerou para a velha guarda um destaque nos noticiários do carnaval de 2005 e no universo do samba que de outra forma não seria experimentado, e que culminaria em 2010, com a Velha

de fevereiro, "Dupla expectativa", no Bom Dia Brasil, "Preocupação em Madureira", no RJTV 1 edição, "Festa e Tristeza", no Jornal Hoje e "Alívio em Madureira", no RJTV 2a edição; no dia 10 de fevereiro, "Madureira amarga resultado", no RJTV 2a edição. No dia 11 de fevereiro, "Troca-troca no samba", veiculada no RJTV $2^{\mathrm{a}}$ edição, comentava, entre outras notícias, a presença da velha guarda da Portela no desfile das campeãs, junto à Beija-Flor. Disponível on-line no acervo Globo.com: http://www.globo.com/. Último acesso em 10 jan. 2011.

${ }^{2}$ Na reportagem "Madureira amarga resultado", comenta-se que as três escolas de samba do bairro de Madureira - Portela, Império Serrano e Tradição - ficaram nas três últimas posições do Grupo Especial, tendo sido rebaixada a Tradição. Nessa mesma reportagem, Tia Surica é citada afirmando que, se a velha guarda entrasse no desfile, a escola teria descido.

${ }^{3}$ Nomenclatura adotada a partir da criação da LIESA, em 1984, para caracterizar o grupo das escolas que apresentam os melhores resultados em cada carnaval.

${ }^{4}$ Adotarei Velha Guarda da Portela, com letra maiúscula, para designar o grupo de cerca de 12 pessoas que integram o conjunto musical assim chamado.

${ }^{5}$ O jornal Extra do dia 20 de janeiro de 2010 noticiava: “A decisão de abrir o desfile portelense com os baluartes foi da dupla de carnavalescos Amauri Santos e Alex de Oliveira. Por considerarem a águia e a velha guarda as peças mais valiosas da Portela, os artistas resolveram unir o útil ao agradável no próximo carnaval da agremiação, que vai falar sobre a tecnologia".

${ }^{6}$ Sérgio Cabral considera uma fotografia de jovens da Zona Sul cheirando lança-perfume na quadra da Mangueira, intitulada "Mangueira pede socorro" e publicada pelo Jornal do Brasil no dia 11 de fevereiro de 1958, como "o primeiro documento demonstrando que o sucesso que as escolas começavam a fazer entre o pessoal da Zona Sul não era tão importante para elas” (1974, p. 128). 
Guarda no carro abre-alas em vez de ao final do desfile. A exclusão no desfile, ao repercutir, funcionou como reforço do valor simbólico da velha guarda.

O tempo que cada escola teria para passar pela avenida foi pela primeira vez um quesito de julgamento no carnaval de 1960, quando Portela e Estação Primeira de Mangueira, respectivamente em $1^{\circ}$ e $2^{\circ}$ lugar na apuração, foram penalizadas por atrasos, ficando o título com o GRES Acadêmicos do Salgueiro, que estava em $3^{\circ}$ lugar. Depois de um violento conflito entre polícia e sambistas, ficou decidido que o título de campeã deveria ser dividido entre as cinco primeiras colocadas: Portela, Salgueiro, Mangueira, Unidos da Capela e Império Serrano (CABRAL, 1974, p. 134). Há também o registro de sete pontos perdidos por cronometragem pelo Império Serrano em 1964, quando a escola desfilou com o samba-enredo Aquarela brasileira, de Silas de Oliveira (VALENÇA \& VALENÇA, 1981, p.65). As mudanças no julgamento dos desfiles, aliadas à dinâmica trazida pela incorporação dos sambas-enredo no mercado fonográfico e à entrada em cena de novos atores nas escolas - em especial os carnavalescos, os banqueiros de bicho e a classe média ${ }^{7}$ - inspiraram movimentos de resistência como a fundação, em 1975, do Grêmio Recreativo de Arte Negra e Escola de Samba (GRANES) Quilombo.

Nas páginas iniciais de $O$ samba, na realidade... a utopia da ascensão social do sambista, o pesquisador e compositor Nei Lopes (1981), um dos fundadores do Quilombo, apresenta a letra de Quesitos, parceria sua com Wilson Moreira, inédita em disco, em que, criticando os critérios de julgamento de escolas de samba, recupera-lhes um significado alternativo (grifos do autor):

\author{
Ao compasso desta melodia \\ Lembro o velho samba-enredo \\ Samba de mais harmonia \\ Samba de valentia, sem medo \\ Samba mistério e segredo \\ Depois que se apagou a gambiarra \\ Virou moda, virou farra \\ O que foi religião \\ Hoje o samba está no alto \\ Sem ter os pés no chão \\ Se a realidade é esta \\ Eu prefiro a fantasia \\ Esta evolução não passa de ilusão \\ É bolha de sabão, é alegoria
}

Iaiá, ioiô

\footnotetext{
${ }^{7}$ Frente à complexidade da questão, talvez uma nomenclatura alternativa fosse necessária. O que se pode afirmar é que, a partir do final da década de 1950, há registros de aumento significativo no número de componentes das escolas que vinha de regiões mais abastadas da cidade.
} 
Samba exige muito amor

Amizade e devoção.

Vamos empunhar nossa bandeira

Levantar essa poeira

Sem tirar os pés do chão

Aparece aí a idéia de um samba sagrado, vinculado a valores religiosos, feito no passado, em oposição ao novo, que virou moda desprovida de significação. Essa composição encerra em imagens poéticas o argumento central do livro de Nei Lopes: o gênero se tornou bem de consumo amplamente requisitado, mas o sambista não ascendeu social ou economicamente.

A história do samba carioca é marcada por controvérsias, lacunas e negociações. Sua elevação a objeto "digno" de estudos deve muito aos esforços de jornalistas diretamente envolvidos no universo da música popular urbana a partir da década de $1930^{8}$. Deve-se levar em conta, ao iniciar uma dissertação que tratará das Velhas Guardas musicais de duas escolas de samba fundadas na primeira metade do século XX que, se o gênero musical e o universo do samba são tão novos na história do Rio de Janeiro quanto difíceis de apreender em sua totalidade, o estudo sobre música popular no Brasil é um campo ainda mais recente entre historiadores ${ }^{9}$.

A abordagem escolhida para este trabalho, a da oralidade, deve-se à observação de que a matéria-prima do samba e do carnaval carioca tem na expressividade musical popular seu ponto central. Um trabalho de história oral parece adequado ao estudo de um gênero cujas expressões - as canções - sobrevivem, por assim dizer, na performance renovada, ou na reprodução de sons gravados. Considerando que a sociedade brasileira se modernizou, mas sem abolir a herança de um modelo escravista, oral e iletrado, a música popular funcionaria como forma de expressão para a esmagadora maioria da população, transmitindo todo tipo de "recado", chegando a toda parte sem intermediários ${ }^{10}$.

Perguntar o que teria mudado nas escolas de samba dos anos 2000 parece uma falsa questão, pois induz pensar num modelo "original” bem definido. Em grande parte das análises sobre sua constituição e desenvolvimento em diferentes momentos, o que se nota é um gênero

\footnotetext{
${ }^{8}$ Carlos Sandroni, em "Adeus à MPB" (2004), identifica o surgimento de um tipo novo de produção intelectual sobre a música a partir das publicações de Alexandre Gonçalves Pinto e Francisco Guimarães (Vagalume).

${ }^{9}$ Cf. José Geraldo Vinci de Moraes (2007), que diagnostica que a partir dos anos 1980 teria havido um esforço para ampliar os estudos sobre música popular para além da crônica jornalística, de biografias e da crítica musical, sendo que entre historiadores de ofício apenas muito lentamente se abriu esse campo.

10 Essas idéias foram discutidas no curso "História, memória e música popular: dilemas, impasses e possibilidades de construção do conhecimento histórico", ministrado pelo Professor José Geraldo Vinci de Moraes no Programa de Pós-Graduação em História Social da FFLCH/USP, ao longo do $1^{\circ}$ semestre de 2009.
} 
musical em constante mudança, um universo de valores e categorias que em momento algum chega a se encerrar num círculo bem delimitado de referências. É possível, no entanto, procurar identificar como são as escolas de samba da primeira década do século XXI em relação a períodos anteriores, observando que elas passaram por um processo de adaptação ao longo do tempo, na medida em que novos atores entravam em cena. A partir da indagação sobre o que estaria diferente no samba em relação à primeira metade do século passado é que se chega ao assunto principal deste trabalho: se as escolas de samba estão em constante transformação, que muito se relaciona ao fato de terem sido incorporadas ao modelo de exploração comercial próprio do capitalismo, qual seria o lugar das velhas guardas, reconhecidas como guardiãs da tradição ${ }^{11}$, para as escolas de samba? O que se observa é uma relação entre velha guarda e escola de samba marcada por uma dinâmica própria dos olhares de cada uma como "entidade": se o objetivo manifesto da escola de samba é competir para vencer os desfiles - uma realização “exterior”, já que pressupõe o julgamento a partir de fora - e sendo sua perspectiva a da permanente inovação, a característica da velha guarda seria justamente a de olhar para o passado, valorizando a história e os integrantes da escola, o seu aspecto "interior".

Seria necessário, para bem avaliar a questão, uma pesquisa que abarcasse todas as velhas guardas existentes, sua trajetória, repertório musical e narrativas de seus componentes. Para dar início a esse esforço, proponho, timidamente, começar por uma aproximação das Velhas Guardas musicais: os grupos de pouco mais de uma dezena de compositores, cantores e músicos, em geral integrantes das velhas guardas "amplas" de suas escolas, destacados para levar, em apresentações musicais e gravações, o repertório dos antigos compositores da agremiação a um público abrangente. A Velha Guarda da Portela, que se organizou como conjunto musical a partir do disco Portela, Passado de Glória (1970), produzido por Paulinho da Viola, afigurou-se um bom ponto de partida para adentrar os incertos e abissais caminhos do samba. Como forma de pormenorizar a pesquisa, pareceu pertinente iniciar o levantamento de narrativas e repertório da Velha Guarda do Império Serrano, escola vizinha à Portela geograficamente, que com ela disputou, a partir de sua fundação (1947), as primeiras colocações no carnaval e, a partir da "modernização" das escolas, por volta da década de 1970, experimentou sucessivas crises.

\footnotetext{
${ }^{11}$ As referências principais adotadas para pensar a tradição foram Hobsbwam (1984) e Napolitano (2007).
} 
Velha guarda, no mundo do samba ${ }^{12}$, é necessariamente um conjunto de sambistas e pessoas envolvidas no cotidiano do samba e do carnaval, que reivindica um lugar no presente das escolas de samba e, mais que qualquer outro, está em constante relação com o passado. Quando o modelo que se adota é o do consumo e da padronização ou, como lembra Hobsbawm, quando se vive em sociedades nas quais o passado é cada vez menos importante (1984, p. 20), observar de que maneira se constroem narrativas voltadas para a preservação da tradição - o que já indica uma ruptura de continuidade - ajuda a fazer aflorar contribuições para entender o que vem a ser essa tradição.

A presente dissertação divide-se duas partes. Na primeira, são apresentados e desenvolvidos temas em torno do problema: descrevo o histórico do projeto e os procedimentos de pesquisa adotados, acrescentando a isso, como forma de iniciar as análises sobre o tema, narrativas em forma de letras de sambas, propondo seu uso como documentos (capítulo 1); relato o processo de produção das entrevistas e aponto questões a partir de sua análise individual e em conjunto (capítulo 2); e apresento três temas que foram particularmente marcantes ao longo da presente pesquisa (capítulo 3). Na segunda parte, encontram-se as narrativas na íntegra; nos encaminhamentos finais, procuro dar continuidade aos questionamentos apresentados como ponto de partida para a dissertação e apontar caminhos para desenvolvimentos futuros dos temas que mereceriam aprofundamento.

O CD anexo reúne arquivos de áudio com os sambas citados ao longo da dissertação, junto com breves trechos das entrevistas, como forma de apresentar em sua materialidade alguns dos documentos usados como corpus documental.

\footnotetext{
12 José Sávio Leopoldi (1977) fala sobre o mundo do samba como o universo resultante de um processo em que se destacam os aspectos étnico, musical e urbano, que "recobre o conjunto das relações sociais de um grupo considerável de agentes, cuja especificidade reside na valorização coletiva de um gênero musical - o samba - e, conseqüentemente, na sua importância em face da matriz de significados culturais do referido grupo" (p. 13). As escolas de samba seriam o locus por excelência dos padrões comunitários envolvidos nesse mundo.
} 


\section{PARTE I}

\section{Histórico e procedimentos de pesquisa}

O projeto com o qual se iniciou a produção desta dissertação originou-se do trabalho desenvolvido como conclusão do curso de Graduação em Jornalismo da PUC-Rio, em 2003. Formulavam-se, ali, indagações sobre a memória que sambistas e moradores das favelas do Rio de Janeiro guardariam da Ditadura Militar (1964-1984), procurando exercitar um olhar atento à predominância de uma análise política sobre a análise social na compreensão do período.

A partir do ingresso no Programa de Pós-Graduação em História Social da FFLCH/USP, em 2007, o projeto passou por uma série de leituras críticas e reformulações, passando o interesse a se concentrar nos sambistas. Desde o princípio, as narrativas dos colaboradores ${ }^{13}$ foram consideradas como os fios condutores para a análise, que seria tecida priorizando as entrevistas e as canções gravadas. Quatro marcas no tempo serviram como referência para a proposta reformulada: a gravação do primeiro LP de sambas de enredo, em 1968; a gravação do disco Portela, passado de Glória, em 1970; a inauguração da Marquês de Sapucaí, em 1984; e a criação da LIESA, no mesmo ano.

A análise apontaria, principalmente, para o ser sambista: como se definiam ou não os compositores e intérpretes do gênero, como se dava a sua ligação com as escolas - estando essas redes inseridas em uma "geografia" - e como, por fim, se construía uma história não "formal" (ou não escrita) da escola e do samba carioca. O momento de escutar as narrativas que esses artistas formulassem sobre si mesmos, assim como as canções que compunham e escolhiam cantar, exigiria uma discussão sobre como lidar com a memória ao buscar informações que não ficaram de outra forma registradas. Tratava-se de valorizar a memória, no tempo "presente", dos colaboradores com os quais se trabalharia, sendo o interesse principal da pesquisa ouvir sambistas ligados a escolas de samba do Rio, procurando traçar junto com eles o "mapa" de suas trajetórias de vida e das de suas escolas. A partir da observação das entrevistas e do repertório musical desses colaboradores, seria possível estabelecer ligações entre as narrativas e chegar a compreensões acerca da memória coletiva dessa comunidade de destino ${ }^{14}$.

\footnotetext{
${ }^{13} \mathrm{O}$ conceito de "colaborador" é proposto para se pensar a relação entrevistador - entrevistado, entendendo que se trata de um trabalho compartilhado, do qual participam ativamente ambas as partes (Cf. Meihy, 2005).

${ }^{14}$ A comunidade de destino é o coletivo que carrega uma experiência compartilhada, a partir da qual se origina e à qual se destina a pesquisa (Cf. Mehiy e Holanda, 2007).
} 
Foi a partir do trabalho de campo e das primeiras entrevistas gravadas que optei por estudar as Velhas Guardas musicais da Portela e do Império Serrano, como ponto de partida para o estudo das velhas guardas.

Os procedimentos adotados pelo Núcleo de Estudos em História Oral podem ser resumidos nas seguintes etapas: elaboração de um projeto, estabelecimento do "ponto zero", desenvolvimento de redes, realização de entrevistas, tratamento do texto resultante das entrevistas - nas três etapas de transcrição, textualização e transcriação ${ }^{15}$-, validação das entrevistas e devolução. Cada um desses momentos demanda tempo e dedicação com os quais nem sempre pude contar. Por isso, quando foi preciso estabelecer prioridades, concentrei esforços na produção e no tratamento das narrativas.

Paralelamente ao período de reformulação do projeto, em que o interesse principal da pesquisa começou a ser mais claramente expresso, dei início à pesquisa de campo. O ponto de partida foi o encontro com José Inácio dos Santos, ou Zé Katimba, meu "ponto zero", sambista que participou da fundação da Imperatriz Leopoldinense e passou, alguns anos depois de seu afastamento da escola, a conviver com a Velha Guarda da Portela. As relações, identificações, e os cuidados ao entrar no espaço da escola que não é a sua "de coração" ficaram presentes desde o primeiro dia de convivência, em agosto de 2008, numa feijoada na Portela.

Nessa primeira ida a campo, a caminho da quadra, Zé Katimba explicou como a Portela o acolheu, levando-o para desfilar junto com a Velha Guarda. No Portelão ${ }^{16}$, onde acontecia a feijoada, estava sendo comemorado o aniversário de Candeia e de Monarco - e para quem não soubesse, não pareceria que Candeia tinha morrido 30 anos antes. Zé Katimba, do lado de fora da quadra, era cumprimentado por todos os integrantes da Velha Guarda que passavam e, mais de uma vez, sua presença foi registrada ao microfone. Mas quando perguntei se ele não ia entrar, disse que não, explicando depois que não queria parecer oportunista e roubar o lugar de outros sambistas que estavam lá, que eram da comunidade. Essa ética do samba, de "chegar devagar" em terras dos outros, ficou muito visível.

Em outubro de 2008 acompanhei a entrevista coletiva que o jornalista Fernando Paulino organizou em forma de feijoada no Candongueiro, casa de samba de Niterói, a partir

\footnotetext{
${ }^{15} \mathrm{O}$ conceito de trascriação proposto por Meihy (2005) é inspirado no adotado pelos irmãos Campos no campo da Lingüística. A partir da observação de que a mera transcrição reduz significativamente aquilo que se passa durante uma entrevista, propõe-se essa espécie de "tradução" do oral para o escrito. Na transcriação devem estar presentes elementos que não se manifestam na enunciação de palavras, como as emoções e os silêncios.

${ }^{16}$ Nome da sede da escola inaugurada em 1972, em Madureira.
} 
da qual finalizou o livro Zé Katimba - que grande destino reservaram para você! (2009). A partir dessa e de outras situações, ficou clara a crítica de Zé Katimba ao modelo adotado nas últimas décadas pela escola que ajudou a fundar, além de se marcarem os valores que considerava fundamentais para um sambista: a autenticidade, a inspiração, a verdade. Também é contundente a crítica ao limitado reconhecimento dispensado ao compositor de samba, que muitas vezes expressa com ironia: "preciso ficar cantando pedacinho de música para saberem quem eu sou", ou "tenho que ganhar dinheiro, nem que seja honestamente".

A partir dos contatos com Zé Katimba, conheci Eli Briareu, grande conhecedor de Madureira, apreciador do bairro, do samba e da boêmia, atualmente motorista de táxi, que exerceu dupla função de guia: pelas ruas da cidade e pelos "caminhos" do samba. Foi Eli quem me levou à casa de Wilson das Neves em outubro de 2009. As conversas com ele foram sempre esclarecedoras, porque permitiam entender se algumas das idéias em que eu pretendia investir reverberariam na prática.

Considero como meu segundo "ponto zero" Jorge Luis Amaral, o Doutor Bigu, médico da Santa Casa de Misericórdia do Rio de Janeiro e admirador de samba que, por ser médico da rede pública, mas não apenas por isso, é muito próximo de diversos sambistas ${ }^{17}$. Fora ele quem me levara, ainda em 2003, à casa de Noca da Portela para a gravação da única entrevista que fiz no contexto da pesquisa de Graduação. As entrevistas com Monarco, Ivan Milanez e Noca da Portela feitas no final de janeiro e começo de fevereiro de 2010, assim como as com Zé Luiz do Império Serrano, Tia Surica, Serginho Procópio, Balbina, Áurea Maria e Lindomar, em julho do mesmo ano, foram realizadas literalmente graças ao seu aval. Muitas vezes, quando eu telefonava para me apresentar ou, posteriormente, falar sobre a validação, "amiga do Doutor Bigu” eram como palavras mágicas, que levavam a conversa para um nível de familiaridade e interesse que não sei se seria possível alcançar nos limitados encontros de uma pesquisa de mestrado.

Em mais de um episódio com os colaboradores desta pesquisa deparei-me com dificuldades em torno dos preceitos da história oral. A mais marcante foi constatar que grande parte de meus colaboradores me considerava como jornalista. Passei a questionar se seria possível firmar uma efetiva colaboração com alguém que não está a par da especificidade do trabalho proposto - como dizer que trabalharei junto com alguém que não sabe no que estou trabalhando, ou de que maneira? A situação foi importante para depurar o conceito de

\footnotetext{
${ }^{17}$ No blog Meu Lote, o compositor e pesquisador Nei Lopes define: "Brasileiro, socialista e de gosto refinado, Bigu há muito que fez sua opção preferencial pelo Samba. E aí, juntando o útil ao agradável, carregando na maletinha preta um estetoscópio e um agogô, ele se tornou o anjo-da-guarda do samba". Disponível em http://www.neilopes.blogger.com.br/2008_07_01_archive.html, último acesso em 11 jan. 2011.
} 
colaboração, torná-lo mais amplo: no momento em que se propõe uma entrevista de história oral e a outra parte aceita, a colaboração se estabelece. Talvez eu esperasse uma modalidade mais participativa, mas foi importante entender que é a possibilidade de participação que qualifica esse contato.

Outro tema que passou a ser de meu interesse foi o do "formato-entrevista". Por mais disposta que eu estivesse a deixar o colaborador narrar sua história como desejasse, minha simples presença e a situação da entrevista já representaria um condicionamento das possibilidades do que seria dito. Até em função de me considerarem jornalista, alguns dos colaboradores falavam como se já estivessem sendo instantaneamente publicados. Isso limita as possibilidades da história de vida, mas parece claro que o colaborador, longe de ser inocente em sua narrativa, diz o que quer, também em função das expectativas e da empatia estabelecidas com o pesquisador.

O momento de transcriar foi trabalhoso, mas recompensador, principalmente ao devolver os textos para aprovação: mais de uma vez recebi comentários de colaboradores surpresos com o quão interessante era a sua narrativa; como se depois de organizada em forma de texto sua vida tivesse ganhado um novo brilho. 
O quadro abaixo representa a execução das tarefas percorridas com a pesquisa:

\section{ETAPAS DA PESQUISA}

\begin{tabular}{|c|c|c|c|c|c|c|c|c|c|c|c|c|}
\hline 2008 & $\begin{array}{c}\text { Mês } \\
1\end{array}$ & 2 & 3 & 4 & 5 & 6 & 7 & 8 & 9 & 10 & 11 & 12 \\
\hline \multicolumn{13}{|l|}{ Curso de 3 disciplinas na Pós-Graduação } \\
\hline \multicolumn{13}{|l|}{ Contatos e pesquisa de campo inicial } \\
\hline \multicolumn{13}{|l|}{ Reformulação do projeto } \\
\hline 2009 & $\begin{array}{c}\text { Mês } \\
1\end{array}$ & 2 & 3 & 4 & 5 & 6 & 7 & 8 & 9 & 10 & 11 & 12 \\
\hline \multicolumn{13}{|l|}{ Curso de 1 disciplina na Pós-Graduação } \\
\hline \multicolumn{13}{|l|}{ Pesquisa de campo e entrevistas } \\
\hline \multicolumn{13}{|l|}{ Transcrição e transcriação de entrevista } \\
\hline \multicolumn{13}{|l|}{ Reformulação do projeto } \\
\hline 2010 & $\begin{array}{c}\text { Mês } \\
1\end{array}$ & 2 & 3 & 4 & 5 & 6 & 7 & 8 & 9 & 10 & 11 & 12 \\
\hline \multicolumn{13}{|l|}{ Pesquisa de campo e entrevistas } \\
\hline \multicolumn{13}{|l|}{ Preparação de relatório de qualificação } \\
\hline \multicolumn{13}{|l|}{ Transcrição e transcriação de entrevistas } \\
\hline \multicolumn{13}{|l|}{ Validação de transcriações } \\
\hline \multicolumn{13}{|l|}{ Elaboração e redação da dissertação } \\
\hline 2011 & $\begin{array}{c}\text { Mês } \\
1\end{array}$ & & & & & & & & & & & \\
\hline \multicolumn{13}{|l|}{ Transcrição e transcriação de entrevistas } \\
\hline Validação de transcriações & & & & & & & & & & & & \\
\hline Elaboração e redação da dissertação & & & & & & & & & & & & \\
\hline
\end{tabular}




\subsection{Narrativas musicais}

Sendo o interesse deste trabalho observar como se constroem as narrativas de integrantes das Velhas Guardas musicais da Portela e do Império Serrano, reproduzirei nas próximas páginas letras de sambas de compositores ligados a ambas as escolas. Faço aqui o exercício de tomar uma canção gravada como um documento, que, além de expressar idéias e sentimentos, defende "teses".

Um dia, tu fostes à Lapa ver a malandragem

Perdestes o tempo e a viagem

Como teu samba diz

Eu fui à Portela ver os meus sambistas

Mas consultando a minha lista

Também não fui feliz

Lá falaram-me sobre um terreiro

Onde eles passam o dia inteiro

Num lugar qualquer de Oswaldo Cruz

Fica lá perto de Bento Ribeiro

Aonde Paulo e seus companheiros

Faziam samba que até hoje seduz

Procurando na localidade

Encontrei mano Alvaiade

Nosso antigo diretor de harmonia

Deu-me a sua dica valiosa

É uma casa formosa

Que reúne paz, amor e alegria

Daí, vi os sambistas de fato

Manacéia e Lonato e outros mais

Juro que fiquei boquiaberto

Nunca me senti tão perto

Da Portela dos tempos atrás

Monarco, Homenagem À Velha Guarda da Portela. [faixa 2 do CD anexo]

A referência inicial à canção de Chico Buarque de Hollanda (Homenagem ao Malandro) indica ao mesmo tempo uma resposta ao "gênero" MPB, de que não é na Lapa que o samba está. É mais: o narrador no samba tampouco encontrou os sambistas na escola de samba. Foi então que ouviu falar sobre o terreiro, em um lugar qualquer, mas especificamente de Oswaldo Cruz, que pode estar também no passado, visto que é onde Paulo e seus companheiros, os fundadores da Portela, faziam seus sambas. 
Prosseguindo sua trajetória, o narrador encontra Alvaiade, antigo diretor de harmonia e integrante da Velha Guarda da Portela, que indica o lugar onde encontrar os sambistas "verdadeiros". Parece tratar-se de um dos quintais da Velha Guarda que aparecem no livro de Carlos Monte e João Baptista M. Vargens, caracterizados pelos autores como "espaços de reunião social para as tarefas cotidianas e para os momentos lúdicos” (2001, p. 51), que acabaram se transformando nos lugares onde a Velha Guarda ensaiava. Na casa de Manacéa ficava um desses quintais, sendo os outros três apontados no livro o de Tia Doca, o de Argemiro Patrocínio e o de Surica. O contato com a Velha Guarda da Portela, o grupo já organizado, aproxima o narrador, enfim, do passado como lugar ${ }^{18}$. O mapeamento das localidades e nomes importantes do samba da Portela serve para registrá-los, documentá-los, nessa matéria intangível que é a canção, e a referência aos "tempos atrás" indica um elemento de melancolia e de um passado de consagração e tradição que se repete em muitos outros sambas.

A temática dos sambas de quadra contrasta com a exaltação nacional dos sambasenredo, ao contar histórias que dizem respeito ao comportamento individual ou à identidade coletiva da comunidade à qual pertencem seus compositores. Nos sambas gravados pela Velha Guarda da Portela isso é marcante: muitas vezes ao terminar de cantar o samba, o cantor comenta alguma informação, como se estivesse falando com quem escuta, contextualizando. Um exemplo está no disco Grandes Sambistas: Velha Guarda da Portela (1986), em que o compositor Casquinha, ao final de Para o bem do nosso bem, de Alvaiade, comenta:

Rapaziada, era assim que, no domingo de manhã, lá na Portelinha ${ }^{19}$, a gente fazia aquele pagode. Uma garrafinha de cana - uma garrafa de cana não, algumas garrafas de cana - cabrito frito, e a gente, tomando cana e cantando esses pagodes da antiga. Que saudade, minha gente. Que saudade!

[faixa 3 do CD anexo]

Esse recurso de gravar com a voz informações que registram o ambiente em que se produziu o samba ou nomeiam aqueles que estão presentes na gravação aparece também em sambas que contam a história do gênero. Como uma nota de rodapé.

O samba nunca foi de arruaça

Quem sabe é Carlos Cachaça, testemunha ocular

Ele viu nos tempos de menino,

Com Cartola e Marcelino, coisas de fazer chorar

Existia um certo preconceito

\footnotetext{
${ }^{18}$ Lembro a frase de LP Hartley: "o passado é um país estrangeiro: eles fazem as coisas de um jeito diferente lá", que inspira o título do livro de David Lowenthal.

${ }^{19}$ Sede da Portela inaugurada na década de 1950.
} 
Que nos tirava o direito de sambar com liberdade

Mas, apesar do preconceito, o sucesso era perfeito

Quando o samba ia pra cidade

Certos sambistas de agora

Não sabem que outrora o samba sofreu

Desconhecem o passado que lhes deu o apogeu

Dizem que pagode é moda, o samba de roda, o partido alto

Mas isso já vem da antiga

A onda de briga é coisa do asfalto

Monarco e Ratinho, O samba nunca foi de arruaça. [faixa 4 do CD anexo]

Esse samba rememora os primeiros momentos do gênero musical, quando, como conta Sérgio Cabral na apresentação a Escola de samba: árvore que esqueceu a raiz (CANDEIA \& ISNARD, 1978), as classes sociais se dividiam como em guetos, o que se comprovava pelo tom de espanto dos jornais quando as escolas começaram a desfilar na Praça Onze: "Os repórteres davam conta das escolas como se surgissem de outro mundo e não da mesma cidade" (p. ix $)^{20}$. Está presente a imagem de que o samba é tão intrinsecamente nobre que, apesar de toda a repressão e o preconceito, prevaleceria mesmo no gosto dos que lhe eram estranhos, os da cidade, os do asfalto, responsáveis pela "onda de briga".

Aparece também a necessidade de lembrar a "certos" sambistas que o passado foi sofrido para que se chegasse no apogeu experimentado por eles, o que reforça a dívida em relação ao passado e aumenta o seu valor. Na gravação desse samba, no LP - também lançado como CD - Samba pras moças (1995), Zeca Pagodinho registra ao final a presença da Velha Guarda da Portela, saúda Oswaldo Cruz e informa que o samba é de autoria de Monarco e Ratinho homenageando Carlos Cachaça, "o grande poeta da Mangueira".

\author{
Menino de 47 \\ De ti ninguém esquece \\ Serrinha, Congonha, Tamarineira \\ Nasceu o Império Serrano \\ $O$ reizinho de Madureira \\ Só se falava da Portela \\ Da Estação Primeira de Mangueira \\ Seu padrinho São Jorge, Santo Guerreiro \\ Que lhe deu prestígio e glória \\ Pra sambar o ano inteiro
}

Molequinho e Nilton Campolino, Menino de 47. [faixa 5 do CD anexo]

\footnotetext{
${ }^{20}$ Matéria d'O Globo citada por Cabral nessa mesma apresentação, declarava depois do desfile promovido pelo jornal em 1933: 'Estamos satisfeitos por termos proporcionado à cidade o espetáculo mais estranho deste ano' (Candeia \& Isnard, 1978, p. ix).
} 
Esse samba comenta o contexto da fundação do Império Serrano, em 1947, como resultado da fusão das agremiações das comunidades da Serrinha, Congonha e Tamarineira. O fato de ter acabado com a supremacia de Portela e Mangueira confere um sinal de legitimidade e grandeza para a escola.

\section{O meu lugar}

É caminho de Ogum e Iansã

Lá tem samba até de manhã

Uma ginga em cada andar.

O meu lugar

É cercado de luta e suor,

Esperança num mundo melhor

E cerveja pra comemorar.

O meu lugar

Tem seus mitos e seres de luz

É bem perto de Oswaldo Cruz,

Cascadura, Vaz Lobo, Irajá.

O meu lugar

É sorriso, é paz e prazer

O seu nome é doce dizer,

Madureira, lá, laiá.

Ah! Que lugar

A saudade me faz relembrar

Os amores que eu tive por lá

É difícil esquecer.

Doce lugar,

Que é eterno no meu coração

E aos poetas traz inspiração

Pra cantar e escrever.

Ai, meu lugar

Quem não viu Tia Eulália dançar

Vó Maria o terreiro benzer

E ainda tem jongo à luz do luar.

Ah! Que lugar

Tem mil coisas pra a gente dizer

$O$ dificil é saber terminar

Madureira, lá, laiá.

Em cada esquina um pagode, um bar

Em Madureira.

Império e Portela também são de lá

De Madureira.

E no Mercadão você pode comprar 
Por uma pechincha você vai levar

Um dengo, um sonho pra quem sonhar

Em Madureira.

E quem se habilita até pode chegar

Tem jogo de ronda, caipira e bilhar

Buraco, sueca pro tempo passar

Em Madureira.

E uma fezinha até posso fazer

No grupo dezena, centena e milhar

Pelos setes lados eu vou te cercar

Em Madureira.

Arlindo Cruz e Mauro Diniz, Meu lugar. [faixa 6 do CD anexo]

Apesar de ser de compositores do Império Serrano e da Portela que não participam das Velhas Guardas musicais, esse samba foi escolhido por sintetizar uma percepção comum a todos os colaboradores da pesquisa, que qualificam Madureira e adjacências como "terra de sambistas". Cria-se uma atmosfera que alia as tradições do jongo ao cotidiano das ruas, o jogo do bicho, o Mercadão, Portela e Império Serrano.

O esquecimento e a vulnerabilidade da memória (e da oralidade, que precisa estar sempre viva) são fatores marcantes para a história do samba. Há histórias emblemáticas como a de Cartola com o jornalista Sérgio Porto, que o teria "salvo" do esquecimento ao reconhecêlo, em 1956, lavando carros em uma garagem de Ipanema e trabalhando à noite como vigia de edifícios $^{21}$; o exemplo do compositor Manacéa, da Portela, que ensinava à filha seus sambas, fazendo com que os decorasse, como forma de gravá-los ${ }^{22}$, e diversas outras imagens que podem ser evocadas para elaborar questões ligadas à condição (social e material) em que são produzidos os sambas.

Marcos Napolitano (2007) identifica nas primeiras décadas do século XX e até os anos 1960 a presença da polêmica com relação ao "lugar" apropriado para o samba, que estaria permanentemente enfrentando a questão de se tornar nacional (não-comunitário), procurando ao mesmo tempo se preservar sócio-culturalmente. Essa negociação seria a marca das escolas e dos compositores de samba e, nesse contexto, a compreensão sobre a tradição representada pelas Velhas Guardas poderia dar as indicações sobre o panorama atual das escolas de samba,

\footnotetext{
${ }^{21}$ Em A síncope das idéias (2007), Marcos Napolitano interpreta a "redescoberta" de Cartola como "elo simbólico" entre duas épocas, reposicionando-o como agente mediador entre o samba e a MPB.

${ }^{22}$ Ver entrevista de Áurea Maria no documentário O Mistério do samba, de Lula Buarque de Hollanda e Carolina Jabor, e transcriação, produzida no âmbito desta pesquisa, reproduzida mais adiante.
} 
todas apoiadas em uma "tradição" e em um "passado glorioso", apesar de recentíssimas em termos históricos.

O trânsito dos sambistas de uma escola para outra é marcado por restrições e trocas que mudam de uma época para a outra. Paulo da Portela, por exemplo, se afastou em 1941 da escola que fundou justamente por buscar uma aproximação entre as diferentes agremiações ${ }^{23}$, o que indica os mecanismos de coesão interna e diferenciação externa entre as escolas. Como forma de expressar o episódio, compôs:

\author{
O meu nome já caiu no esquecimento \\ O meu nome não interessa a mais ninguém \\ E o tempo foi passando \\ $A$ velhice vem chegando \\ Já me olham com desdém \\ Ai, quanta saudade \\ Do passado que se vai lá no além \\ Chora cavaquinho, chora \\ Chora violão também \\ O Paulo no esquecimento \\ Não interessa a mais ninguém \\ Chora Portela, minha Portela querida \\ Eu que te fundei, serás minha toda a vida
}

Paulo da Portela, O meu nome já caiu no esquecimento.

Ao fazer o samba, o compositor garante que essa situação ficará gravada na memória e que o esquecimento será revertido. Mais uma vez, a saudade do passado que não volta é mencionada. Na gravação feita pela Velha Guarda da Portela no disco Homenagem a Paulo da Portela (1988), Monarco "puxa uma nota" ao final (como Casquinha no samba citado antes), falando sobre a desavença de Paulo com a Portela, deixando registrada junto com a música a lembrança do contexto que levou a esse afastamento:

Esse samba o Paulo fez com o coração cheio de mágoa, cheio de saudade da sua querida Portela. Sofreu uma grande ingratidão em pleno desfile da Praça Onze e, (...) dois dias após essa grande paixão, fez esse lindo samba que vocês estão acabando de ouvir. Obrigado, meu professor.

[faixa 7 do CD anexo]

\footnotetext{
${ }^{23}$ Marília Trindade Barboza da Silva e Lygia dos Santos Maciel (1979) esclarecem que havia mais do que os figurinos em jogo naquele episódio. O relato difundido é o de que Paulo da Portela, tendo acabado de chegar de São Paulo com Heitor dos Prazeres e Cartola, os três vestidos com o figurino da apresentação paulistana, se recusou a sair na escola porque Manoel Bam-Bam-Bam exigiu que os dois companheiros trocassem de roupa para desfilar com a Portela. As autoras, no entanto, mostram que havia uma antiga desavença entre Manoel e Heitor, e que o figurino teria sido apenas um pretexto para "barrar" sua entrada. Não obstante, na atitude de Paulo (e no retrato do sambista concebido por essas duas autoras) fica muito marcado o propósito de fortalecer e enobrecer, por meio das trocas entre escolas, o gênero "samba".
} 
Assim, a Velha Guarda, trazendo passagens da história da escola, traz para si a missão e o poder de representar aquilo que identifica como a tradição, de que a um só tempo é tributária e credora.

Ao observar o que canta e, principalmente, como se narra ${ }^{24}$ a Velha Guarda, é possível contribuir para entender o samba nos anos 2000. Entende-se por samba, a esta altura, algo mais amplo do que um gênero musical - todo um universo, ou um mundo, como define Leopoldi (1978), chamado de "misterioso" por pelo menos um antropólogo e dois documentaristas que se dispuseram a desvendá- $10^{25}$.

\footnotetext{
${ }^{24}$ Penso tanto na narrativa de cada colaborador sobre a Velha Guarda de que participa quanto na tradição inventada coletivamente.

${ }^{25}$ Tanto o livro de Hermano Vianna (1995) quanto o documentário de Lula Buarque de Hollanda e Carolina Jabor se chamam $O$ mistério do samba.
} 


\section{Entrevistas}

Foram produzidas, ao todo, onze entrevistas entre maio de 2009 e julho de 2010:

\begin{tabular}{|c|c|c|c|c|c|c|c|}
\hline \multirow{2}{*}{ Colaborador } & \multicolumn{7}{|c|}{ Etapas } \\
\hline & Gravação & Duração & Transcrição & Textualização & Transcriação & Validação & Observações \\
\hline Zé Katimba & $9 / 5 / 2009$ & $65 \mathrm{~min}$. & jul/2009 & jul/2009 & jul/2009 & $\operatorname{mar} / 2010$ & \\
\hline Wilson das Neves & $11 / 10 / 2009$ & $63 \mathrm{~min}$. & $\mathrm{fev} / 2010$ & $\mathrm{fev} / 2010$ & $\operatorname{mar} / 2010$ & jul/2010 & \\
\hline Noca da Portela & $29 / 1 / 2010$ & 99 min. & jul-set/2010 & set/2010 & out/2010 & $\operatorname{dez} / 2010$ & $\begin{array}{c}\text { Parte do áudio foi } \\
\text { prejudicado por mau } \\
\text { contato do microfone }\end{array}$ \\
\hline Monarco & $29 / 1 / 2010$ & 48 min. & jul-nov/2010 & nov/2010 & $\operatorname{dez} / 2010$ & $\mathrm{jan} / 2011$ & \\
\hline Ivan Milanez & $2 / 2 / 2010$ & $80 \mathrm{~min}$. & nov/2010 & nov/2010 & $\operatorname{dez} / 2010$ & $\mathrm{jan} / 2011$ & \\
\hline Zé Luiz do Império & $17 / 7 / 2010$ & $81 \mathrm{~min}$. & $\operatorname{dez} / 2010$ & $\operatorname{dez} / 2010$ & $\operatorname{dez} / 2010$ & $\mathrm{jan} / 2011$ & \\
\hline Tia Surica & $19 / 7 / 2010$ & $20 \mathrm{~min}$. & $\operatorname{dez} / 2010$ & $\operatorname{dez} / 2010$ & $\operatorname{dez} / 2010$ & - & $\begin{array}{c}\text { Ainda não foi obtida a } \\
\text { aprovação final do } \\
\text { texto } \\
\end{array}$ \\
\hline Serginho Procópio & $20 / 7 / 2010$ & $49 \min$. & $\operatorname{dez} / 2010$ & $\operatorname{dez} / 2010$ & $\operatorname{dez} / 2010$ & $\mathrm{jan} / 2011$ & \\
\hline Balbina & $21 / 7 / 2010$ & $158 \mathrm{~min}$. & $\begin{array}{c}\mathrm{dez} / 2010- \\
\mathrm{jan} / 2011\end{array}$ & $\mathrm{jan} / 2011$ & $\mathrm{jan} / 2011$ & $\mathrm{jan} / 2011$ & $\begin{array}{c}\text { A validação foi feita } \\
\text { com Jussara, filha de } \\
\text { Balbina } \\
\end{array}$ \\
\hline Áurea Maria & $27 / 7 / 2010$ & 13 min. & $\begin{array}{c}\text { dez/2010- } \\
\text { jan/2011 }\end{array}$ & $\mathrm{jan} / 2011$ & $\mathrm{jan} / 2011$ & $\mathrm{jan} / 2011$ & \\
\hline Lindomar & $27 / 7 / 2010$ & $53 \mathrm{~min}$. & $\begin{array}{c}\mathrm{dez} / 2010- \\
\mathrm{jan} / 2011\end{array}$ & $\mathrm{jan} / 2011$ & $\mathrm{jan} / 2011$ & $\mathrm{jan} / 2011$ & \\
\hline
\end{tabular}

\section{REDES ESTABELECIDAS}

\begin{tabular}{|c|c|c|}
\hline $\begin{array}{c}\text { Homens da } \\
\text { Velha Guarda }\end{array}$ & $\begin{array}{l}\text { Mulheres da } \\
\text { Velha Guarda }\end{array}$ & $\begin{array}{c}\text { Sambistas } \\
\text { "independentes" }\end{array}$ \\
\hline $\begin{array}{c}\text { Monarco } \\
\text { (Portela) } \\
\end{array}$ & $\begin{array}{c}\text { Tia Surica } \\
\text { (Portela) }\end{array}$ & $\begin{array}{c}\text { Noca da Portela } \\
\text { (Portela) }\end{array}$ \\
\hline $\begin{array}{l}\text { Serginho Procópio } \\
\text { (Portela) }\end{array}$ & $\begin{array}{c}\text { Áurea Maria } \\
\text { (Portela) }\end{array}$ & $\begin{array}{c}\text { Zé Katimba } \\
\text { (Imperatriz Leopoldinense) }\end{array}$ \\
\hline $\begin{array}{l}\text { Wilson das Neves } \\
\text { (Império Serrano) }\end{array}$ & $\begin{array}{c}\text { Lindomar } \\
\text { (Império Serrano) }\end{array}$ & $\begin{array}{l}\text { Zé Luiz do Império } \\
\text { (Império Serrano) }\end{array}$ \\
\hline $\begin{array}{c}\text { Ivan Milanez } \\
\text { (Império Serrano) }\end{array}$ & $\begin{array}{c}\text { Balbina } \\
\text { (Império Serrano) }\end{array}$ & \\
\hline
\end{tabular}


Houve ainda, no dia 19 de julho, uma entrevista de pouco mais de 70 minutos com Carlos Monte, admirador de samba que passou a fazer parte do Departamento Cultural da Portela entre 1972 e 1975 e escreveu, em parceria com João Baptista M. Vargens, A Velha Guarda da Portela, publicado pela Manati em 2001. Essa entrevista funcionou como um importante complemento em relação às demais. Merecem registro as histórias e as idéias principais expressas por ele, que lamento não ter aproveitado melhor em função das limitações de tempo para finalizar a pesquisa, mas que espero poder desenvolver com mais propriedade futuramente.

Carlos Monte chegou à Portela "pelo ouvido", por ser fascinado por música. A qualidade dos sambas da Portela o impressionou, levando-o a viver um momento singular da escola, em que os mais antigos - Ventura, Armando Santos, Alcides Malandro Histórico, entre outros - ainda estavam ativos, mas já tinha chegado uma nova geração, a partir da década de 1950, que trazia nomes como Candeia, Zé Keti, Paulinho da Viola e Waldir 59. De apaixonado, a partir da convivência iniciada na década de 1960, passou a participante. O Departamento Cultural foi criado com a motivação, entre outras, de formar um acervo de informações da Portela. À época, estavam vivos Antonio Caetano e Antonio Rufino, dois dos três principais fundadores da escola (Paulo da Portela completando o trio). Conversava com os dois e com Lino Manoel dos Reis, que ajudou a construir a Portelinha com o dinheiro de uma indenização ganha graças à perda de um dedo na fábrica onde trabalhava.

Havia também, no entanto, uma vontade de modernizar a escola a partir do Departamento Cultural, o que provocou o afastamento de Carlos. A meta de vencer o carnaval, que para ser alcançada muitas vezes leva a ações que não condizem com os preceitos que historicamente deram notoriedade à escola, é outro fator apontado por ele como complicado. Embora não mais no Departamento Cultural, continuou acompanhando a escola de longe, principalmente freqüentando os shows da Velha Guarda da Portela. Em 2004, apoiou a candidatura de Nilo Figueiredo que, ao ser eleito presidente da Portela, o tornou Diretor Cultural, um tanto à revelia do nomeado. Carlos afirma que gostaria de deixar uma marca, de levar adiante o museu da Portela, que deveria ser também virtual, mas a informação, hoje, é muito difícil de ser recuperada.

Há 35 anos, explica, era possível conversar com os fundadores e extrair, se não a verdade, algo próximo disso. Quanto mais tempo passa, mais árdua é a tarefa, que se agrava pelo desinteresse de alguns dos filhos do pessoal da velha guarda, eles próprios já idosos. Também o registro do carnaval é mais complicado quanto mais antigo: sabe-se o samba dos primeiros carnavais, mas não se sabe muito mais, porque na época não se pensou em guardar. 
É uma memória que perece rapidamente. Até o toque da bateria mudou: pouca gente sabe tocar como antigamente; os novos só sabem de ouvir dizer.

Carlos observa ter havido uma mudança, a partir dos anos 1970, na forma como se ingressava na ala de compositores da escola, cujos sambas não mais saíam do "ventre" da escola, citando a expressão de Monarco. Em décadas anteriores, os compositores que queriam se somar à ala de compositores enfrentavam um período de iniciação: começavam acompanhando as reuniões da ala e escutavam atentamente, esperando a sua vez. Assim, ao entrar na Portela, sempre pelo crivo dos mais antigos, já traziam uma forma de tocar e compor que incorporava os valores e o estilo da escola.

Comenta haver três personagens importantes nas comunidades: a parteira ou curandeira, que era quem transmitia experiência da medicina popular; o pai-de-santo, que cumpria o papel de conselheiro social, lidando com o bem e o mal; e o compositor, intérprete do sentimento popular vigente na comunidade. Os compositores eram mais ou menos benquistos em suas escolas na medida em que seus sambas ecoassem os sentimentos das pessoas. A escola de samba era o lugar da apresentação dessas músicas, e quem as aprovava eram as mulheres, a quem o compositor se dirigia. Quando as mulheres não gostavam, o samba morria. Carlos percebe três temas principais para os sambas de quadra: a localidade (o compositor fala bem por estar em seu lugar, ou com saudades, quando sai); a vida amorosa (amor e desamor); e os acontecimentos do cotidiano.

Observa que, até a década de 1950, não se dava muita importância ao samba-enredo. Quando, a partir dessa época, o samba-enredo começou a crescer, apareceu a "turma do muro", na qual se destacou Candeia - que aos 16 anos ganhou o samba-enredo da Portela, com Seis Datas Magnas, em parceria com Altair Prego - ao lado de Waldir 59, Picolino e vários outros. Esses constituíram a Ala dos Impossíveis e passaram a compor sambas-enredo, com o apoio dos antigos, que eram até então os responsáveis por esse tipo de composição.

Considera notável o disco produzido por Paulinho da Viola em 1970 porque registrou, além das composições, as vozes dos antigos. Do ponto de vista formal, a Velha Guarda se constituiu nesse momento, e a organização do grupo se deu gradualmente, tendo sido decisivo para o sucesso do grupo, segundo João Baptista M. Vargens, um show no Teatro João Caetano. As pastoras, naquele momento, eram Vicentina, irmã de Natal, e Iara. Carlos destaca o papel de "ministro da justiça" de Manacéa, qualificação que aparece também em seu livro sobre a Velha Guarda. Era Manacéa quem entrevistava os possíveis "guardiões da música", tarefa para a qual observava também o comportamento dos compositores. 
A velha guarda, ou seja, todos os veteranos portelenses - presidida pelo Seu Vieira e em seguida pelo Seu Marinho - passou a se reunir na Portelinha graças à iniciativa de Armando Santos, que solicitou o espaço a Carlinhos Maracanã, então presidente da escola, quando houve a mudança para o Portelão, inaugurado em 1972.

Como fatores que levaram às transformações observadas diretamente na escola, Carlos Monte destaca o momento em que o samba-enredo passou a render dinheiro. Há movimentos de resistência, como a promoção de concursos de samba de quadra, tanto dentro quanto fora da escola, e há compositores defendendo a instituição de regras, como a de que só possa fazer samba-enredo o compositor que tenha mostrado pelo menos um samba feito sozinho, sem relação com o enredo; e que haja um período mínimo de um ano de vida na escola antes que se adquira o direito de concorrer com samba-enredo.

Um processo que vê com extremo interesse é o de artistas que não necessariamente são da escola, mas que têm se dedicado ao samba como forma de apresentação musical, que cada vez tocam mais o repertório da Velha Guarda. O samba de quadra cada vez aparece menos na escola, mas os sambas antigos são cada vez mais pesquisados, um fenômeno que não se restringe ao Rio de Janeiro: os grupos Terreiro Grande e Batalhão de Sambistas, de São Paulo, por exemplo, fazem sambas que considera maravilhosos e tocam o repertório antigo do Rio. Essa memória vai ficar também por conta dessas pessoas, que trazem para suas apresentações e discos novas composições de antigamente.

Essa "renovada admiração" pela Velha Guarda irá ajudar a preservar o que foi feito no passado. Marquinhos de Oswaldo Cruz, Tuco, Eduardo Gallotti, Sururu na Roda, Pedro Miranda e Teresa Cristina são exemplos de artistas que cantam não só Velha Guarda, mas que certamente a incluem em seus repertórios. Carlos conta que ele mesmo participou da organização, com o grupo Sururu na Roda, de um show em homenagem ao centenário de Haroldo Lobo. Perguntado sobre o que identificaria como elementos constituintes do talento dos sambistas da Portela, não hesita: "o dom do samba é inteiramente inexplicável”.

Com essas referências na bagagem, passo a falar do percurso das entrevistas feitas com os colaboradores deste projeto. 


\subsection{Produção}

A escolha dos colaboradores se deu em função de critérios pré-estabelecidos, mas também, logicamente, da oportunidade de realizar as entrevistas. Ainda que as Velhas Guardas musicais sejam grupos menos numerosos que a velha guarda "geral" das escolas, não houve tempo suficiente para entrevistar todos os integrantes das Velhas Guardas da Portela e do Império Serrano. Ao todo, foram entrevistados quatro integrantes (dois homens e duas mulheres) de cada Velha Guarda, além de três compositores que têm relação com as escolas, mas não - ou não mais, no caso de Zé Luiz do Império - pela via da participação na Velha Guarda.

Todos os colaboradores receberam a transcriação impressa, o CD com o áudio da entrevista e uma pequena carta explicitando os procedimentos da pesquisa. Com todos, exceto Tia Surica, foi finalizada a validação.

\section{Zé Katimba - José Inácio dos Santos}

Foi estabelecido como "ponto zero" e primeiro entrevistado desta pesquisa em virtude da sua proximidade com a Velha Guarda da Portela, ao lado da qual desfilou em 2008, durante um período de afastamento da Imperatriz Leopoldinense. Pareceu pertinente, para dar início à produção de entrevistas, escutar alguém que, ainda que não fosse efetivamente da Velha Guarda da Portela, tivesse sido acolhido por ela. Mais tarde, no livro contando a história do sambista leopoldinense, Monarco apareceria definindo-o como integrante do seu "time de guerreiros", acima das disputas entre escolas, mas com lugar permanente junto à Velha Guarda da Portela (PAULINO, 2009, p. 116).

No carnaval de 2009, em que se comemoravam os 50 anos da fundação da Imperatriz Leopoldinense, Zé Katimba voltou à sua escola "de coração" como homenageado, desfilando no carro da velha guarda. A sinopse para o enredo Imperatriz... Só quer mostrar que faz samba também!, formulada pela carnavalesca Rosa Magalhães, dava destaque ao episódio em que o sambista inspirou o personagem que levava seu nome na novela Bandeira 2, de Dias Gomes, que usava como trilha sonora o samba-enredo Martim Cererê, composto por ele em parceria com Gibi e defendido pela Imperatriz em 1972. No samba-enredo efetivamente apresentado na Marquês de Sapucaí em 2009, aparecem referências à novela, a Martim Cererê e a $O$ teu cabelo não nega (só dá Lalá), outro samba-enredo feito por Zé Katimba em 
parceria com Gibi e Serjão em homenagem a Lamartine Babo, com o qual a Imperatriz desfilou em 1981.

Apesar de meu primeiro contato com Zé Katimba ter acontecido em agosto de 2008, a entrevista foi gravada apenas em maio de 2009. Ao longo desse período, foram diversos encontros: o primeiro, quando fomos juntos, recém-apresentados, para a Portela; alguns dias depois, fomos à Rádio MEC, para assistir, do auditório, ao programa de Adelzon Alves; em outubro de 2008, estive na entrevista coletiva em forma de feijoada organizada por Fernando Paulino na casa de samba Candongueiro; em janeiro de 2009, junto com Nely Silveira e Eli Briareu, conversamos num bar em frente à Praça São Salvador, em Laranjeiras.

Um episódio curioso foi minha visita, ainda em agosto de 2008, ao Museu da Imagem e do Som (MIS) do Rio de Janeiro, onde listara os "depoimentos" pelos quais tinha interesse. Ao assistir à primeira parte do depoimento de Zé Katimba, gravado em 2001, ficou bastante claro que seu discurso, altamente articulado, era uma narrativa já bem fixada. Tinha estado com ele durante praticamente duas tardes inteiras e todas as histórias que ele contara estavam contidas naquelas quase três horas de entrevista. Foi interessante observar que, como sói acontecer com figuras públicas, muito freqüentemente instadas a falar sobre suas trajetórias, essa grande narrativa talvez se sobrepusesse a outras "secundárias", mas nem por isso menos significativas para o compositor.

A entrevista foi gravada no dia 9 de maio de 2009, em Santa Rosa, Niterói, na casa de Jubert e Rita de Cássia, um casal de amigos de Nely, logo depois de um almoço preparado pela anfitriã.

As principais marcas da entrevista são a gratidão e a sabedoria. Zé Katimba é grato ao samba, que lhe deu, junto com as mulheres, as maiores alegrias de sua vida. Destaca o valor do conhecimento, que deve ser sempre compartilhado e aberto, com isso reforçando sua própria história, marcada por grandes adversidades e um acesso restrito à educação formal, mas em que se mostra um interesse muito grande pelo mundo e pelo ser humano.

A transcriação, concluída em julho de 2009, foi enviada para apreciação por correio e autorizada sem alterações em março de 2010. Essa aprovação sem emendas, como pude verificar depois, expressava algo como um "voto de confiança" no meu trabalho.

\section{Wilson das Neves}

O segundo entrevistado, dando início à rede da Velha Guarda do Império Serrano, foi Wilson das Neves, a quem fui apresentada por Eli Briareu. Sua entrevista interessava-me por se tratar de alguém da Velha Guarda, seguramente, mas também por se tratar de músico 
considerado um dos "grandes" da MPB, não se restringindo ao samba. Havia ainda a sua produção como compositor, cujo samba talvez mais conhecido e regravado tenha sido $O$ samba é meu dom, em parceria com Paulo César Pinheiro ${ }^{26}$.

A edição de janeiro/fevereiro de 2010 da revista Continuum, do Itaú Cultural, trazia a entrevista intitulada "De pajé para curumim", em que Wilson era entrevistado pelo também baterista Curumin. O parágrafo inicial o apresentava assim:

Nascido na Glória, no Rio de Janeiro, bisneto de escravos e com 55 anos de trabalho como baterista, Wilson das Neves tem na carreira gravações com mais de 600 músicos do Brasil e do exterior. Prestes a lançar o terceiro trabalho solo, Para a Gente Fazer Mais um Samba, é definido pelo amigo Chico Buarque, com quem toca há 26 anos, como "o pulso da banda, termômetro, técnico do time, rei da anedota e pajé", conforme escreveu o poeta no texto da contracapa do CD. Colecionador de plantas, pai de quatro filhos, marido de Silvia, avô de quatro netos e bisavô de João, Wilson é também inspiração para bateristas e cantores da nova geração (...). (p. 16).

O primeiro contato com ele aconteceu no dia 11 de outubro de 2009, a mesma data da entrevista. Eli me acompanhou até a residência de Wilson, no Jardim Guanabara. Conversamos rapidamente, expliquei do que se tratava o projeto e iniciamos a gravação. Suas respostas eram sempre diretas e simples, mas capazes de transmitir uma compreensão profunda sobre o que observa na escola.

O principal argumento expresso na entrevista foi o de que a escola de samba não é mais escola, porque não forma mais ninguém. Fica muito marcada a oposição entre passado e presente, amor e dinheiro, permanecendo o amor pela escola apenas na velha guarda, na bateria e alguns compositores. Não se diz contrário à idéia de modernização, mas sim à deturpação dela decorrente.

A transcriação, produzida no início de 2010, foi também enviada por correio para aprovação. Num primeiro momento, Wilson não sentiu necessidade de ler, dizendo que se eu tinha escrito o que tinha sido dito durante a entrevista não haveria maiores complicações. Insisti um pouco e, após a leitura, ele acabou fazendo correções pontuais que de fato tornaram algumas informações mais precisas.

\footnotetext{
${ }^{26}$ Essa canção aproxima-se do processo de colaboração na história oral: Pinheiro escreve "em nome de" das Neves, sendo que este último canta a música, em primeira pessoa. Está presente na letra o tributo a grandes nomes, os que fizeram "samba bom", que como que avalizam a importância do compositor para o mundo do samba. Além de associá-lo à bateria, seu instrumento, e ao Império Serrano, sua escola, também é reforçada a sua importância como sambista, no verso final: "Pois quem é do samba meu nome não esquece mais não". Paulo César Pinheiro (2010, p. 174) comenta: "E digo nela o que ele diria se escrevesse versos. É um autobiográfico, em mim incorporado, como se eu fosse seu cavalo, seu veículo".
} 


\section{Noca da Portela - Oswaldo Alves Pereira}

Para dar início ao contato com integrantes da Velha Guarda da Portela e continuar a rede de compositores da Velha Guarda do Império Serrano, recorri à ajuda do Doutor Bigu, que prontamente intermediou - e, como foi dito antes, avalizou - o contato com os três colaboradores entrevistados no início de 2010: Noca da Portela, Monarco e Ivan Milanez.

Noca da Portela fora escolhido pela característica de ser um compositor antigo, muito associado - a começar pelo nome - com sua escola, mas que não participava da Velha Guarda musical. Ou seja, permitiria complementar o olhar dos que por definição exercem a função de sentinelas da escola. Sua carreira musical também transcende o universo da Portela, tendo tido forte relação com a comunidade do Tuiuti e a Paraíso do Tuiuti, escola de samba que ajudou a fundar, além de com o Cacique de Ramos, bloco carnavalesco da zona da Leopoldina. Junto com Colombo e Picolino da Portela, formou o Trio ABC da Portela na década de 1960. Compôs músicas em parceria com Candeia, Mauro Duarte, Toninho Nascimento, Dona Ivone Lara, Délcio Carvalho e Nelson Rufino, entre outros ${ }^{27}$.

O contato com Noca da Portela foi, na verdade, retomado, passados pouco mais de sete anos desde a realização da única entrevista feita durante a minha pesquisa de Graduação. Com a ajuda do Doutor Bigu, agendei a entrevista e fui direto à sua casa, no dia 29 de janeiro de 2010, no Engenho de Dentro, mais uma vez acompanhada por Eli. Expliquei brevemente a diferença de abordagem entre a pesquisa passada e a presente e conversamos algum tempo antes de acionar o gravador.

Foi durante essa entrevista que tive meu único, mas inesquecível, problema técnico. Usava um gravador de cassete com microfone acoplado, para melhorar o áudio. Aos cerca de 20 minutos de entrevista desconfiei de alguma coisa errada, e de fato o microfone estava com mau contato. Uma boa parte foi salva, mas o principal mecanismo de segurança foi escrever, imediatamente, com o máximo de detalhes possível, o que Noca tinha narrado até aquele momento. Desconectei o microfone e passei a gravar usando diretamente o microfone do gravador para terminar a entrevista. Mesmo com o problema, foi possível retomar o clima tranqüilo e a concentração.

O ponto central, ao qual Noca voltou mais de uma vez, foi o de que não há mais convivência entre compositores na escola, principalmente porque não se fazem mais sambas de quadra, mas também por uma questão de atitude dos mais novos. Com naturalidade, contou

\footnotetext{
${ }^{27}$ Cf. verbete "Noca da Portela" no Dicionário Cravo Albin da Música Popular Brasileira: http://www.dicionariompb.com.br/noca-da-portela. Último acesso em 23 jan. 2011.
} 
episódios que fazem dele um sambista talentoso, com boa formação - na "escola da vida" assim como na escola de samba -, consciente e politizado.

A transcriação de Noca ficou pronta em outubro de 2010 e foi enviada por e-mail e correio. Noca telefonou antes mesmo de receber o impresso, dizendo que estava muito feliz com a sua história de vida e que certamente minha "matéria" iria "bombar". Mais uma expressão de aprovação ao trabalho.

\section{Monarco - Hildemar Diniz}

Monarco é fortemente identificado com a Velha Guarda da Portela, sendo inúmeras as suas aparições na mídia como representante ou líder do grupo, a começar pelo samba que foi escolhido para integrar e dar nome ao disco da Velha Guarda em 1970: Passado de glória. Àquela época, apesar da pouca idade (menos de 40 anos), já era considerado continuador da tradição. $\mathrm{O}$ interesse em sua colaboração com esta pesquisa estava apoiado nessa qualificação, além de se tratar de compositor de sambas vistos como "tipicamente portelenses" e de sua carreira individual ser indissociável da trajetória e do repertório do grupo.

O encontro com Monarco aconteceu em seguida à entrevista de Noca da Portela, no mesmo dia 29 de janeiro, na Cinelândia. Foi bastante rápida a conversa inicial, em que expliquei o projeto e a abordagem. Ao ligar o gravador, tive uma sensação semelhante à da visita ao MIS, nos primeiros meses da pesquisa: o "formato-entrevista", de tão acionado, produziu uma narrativa fixa linear, quase sem hesitação, de tal modo que durante os primeiros 20 minutos de gravação não houve pausas longas nem foram necessários novos estímulos de minha parte.

Uma das marcas da narrativa de Monarco foi a da qualidade dos sambas. Essa categoria está presente tanto no tom vital (frase central para a compreensão da entrevista) quanto na visão sobre o que deve ser preservado pela Velha Guarda. Estiveram presentes, também, o sinal da gratidão aos antigos e as oposições entre velho (bom, desinteressado) e novo (vazio, comercial).

A validação da transcriação, também enviada por correio no final de 2010, aconteceu no dia 7 de janeiro de 2011, quando nos encontramos novamente na Cinelândia e pude ouvir ainda outra variação do sinal de aprovação: ao assinar a autorização, Monarco comentava que era uma pesquisa feita com boa intenção. 


\section{Ivan Milanez}

Ivan Milanez, o segundo colaborador da Velha Guarda do Império Serrano, foi entrevistado por sua participação no grupo e por ser conhecido como percussionista "purosangue" da Serrinha ${ }^{28}$. Sua narrativa traria os elementos da tradição da sua escola, à qual estava fortemente conectado.

O primeiro contato com Ivan Milanez aconteceu no dia 27 de janeiro de 2010, no Beco do Rato, na Lapa. Depois de Eli e Bigu terem falado que eu o procuraria, encontrei Ivan e Romana, sua mulher, e expliquei com calma a pesquisa. No dia 2 de fevereiro, nos encontramos na Rádio Nacional, onde assistimos ao programa Dorina Ponto Samba, apresentado pela cantora Dorina e o jornalista e compositor Rubem Confete. De lá, como Ivan não indicou um lugar específico para a gravação, partimos o Sindicato dos Médicos, no Centro, onde Bigu conseguiu uma sala vazia.

Uma das atitudes que me chamou atenção durante a entrevista foi que em alguns momentos Ivan se dirigiu a mim como a uma platéia, ou em tom de denúncia. Há mais de uma passagem em que mostra sentir-se prejudicado pela falta de reconhecimento, por exemplo, a iniciativas pioneiras, como o nome escolhido para os grupos musicais que integrou como percussionista, ou a promoção de rodas de samba que teriam sido responsáveis pela revitalização da Lapa nos anos 2000. Mas esse não foi o tom predominante: em muitos outros momentos expressava-se com doçura e simplicidade, procurando sempre se fazer entender de maneira clara.

A validação aconteceu no dia 11 de janeiro de 2011, em Madureira, num bar ao lado de sua casa. Ivan fez correções pontuais ao texto e se interessou pelo tipo de circulação que poderia ter.

\section{Zé Luiz do Império - José Luiz Costa Ferreira}

Passados alguns meses desde as entrevistas de janeiro e fevereiro, quando pude novamente dedicar maior atenção à pesquisa, permanecendo por todo o mês de julho de 2010 no Rio de Janeiro, tratei de ampliar as redes. Foi mais uma vez graças ao Doutor Bigu que entrei em contato com Tia Surica, Zé Luiz do Império Serrano e Serginho Procópio.

No verbete dedicado a Zé Luiz no Dicionário Cravo Albin da Música Popular Brasileira $^{29}$, destaca-se que ele foi o fundador do Pagode da Resistência, "uma das primeiras rodas de samba para revitalização do gênero na década de 1970". Suas parcerias com Nelson

\footnotetext{
${ }^{28} \mathrm{http}: / /$ www.samba-choro.com.br/artistas/ivanmilanez. Último acesso em 10 jan. 2011.

$29 \mathrm{http} / / /$ www.dicionariompb.com.br/ze-luiz-do-imperio. Último acesso em 20 jan. 2011.
} 
Rufino Tempo ê, Prece a Xangô e Todo menino é um rei, gravadas na segunda metade da década de 1970 por Roberto Ribeiro, tornaram-se muito conhecidas. Outras composições citadas são Malandros maneiros, feita em parceria com Nei Lopes, e Nosso nome: resistência, em parceria com Sereno e Nei Lopes, que deu título ao disco de Alcione lançado na década de 1980. Seu primeiro disco solo foi lançado em 2005 pelo Selo Candongueiro. Entre seus parcerios, além dos citados acima, estão Agenor de Oliveira, Nelson Sargento, Ratinho, Wanderley Monteiro e Wilson Moreira.

O primeiro contato com Zé Luiz foi por telefone, primeiro intermediado por Bigu, em seguida direto para marcar a entrevista, que aconteceu em sua residência, em Oswaldo Cruz, no dia 17 de julho de 2010. O interesse em escutá-lo para esta pesquisa dava-se em função tanto de sua carreira como compositor quanto de sua participação na organização da Velha Guarda do Império Serrano. Embora não mais fizesse parte do grupo, certamente teria contribuições importantes a fazer.

A entrevista de Zé Luiz foi agradável, tendo sido forte a impressão de franqueza em seu discurso. Pude observar com maior nitidez o que seria a "personalidade" imperiana, presente nas entrevistas de Wilson das Neves e Ivan Milanez, vinculada à resistência e à valorização da cultura de raízes africanas. Houve consenso em muitas das críticas à escola, mas Zé Luiz enxergava a posição da velha guarda ao final do desfile como positiva, distinguindo-se da opinião de Wilson.

A transcriação foi enviada por correio em dezembro de 2010 e finalizada no dia 5 de janeiro de 2011, quando nos encontramos na Cinelândia. Zé Luiz complementou passagens e juntos fizemos um trabalho de edição, para deixar o texto mais fluido e sucinto. Enviei o texto refeito por e-mail e, no dia 14 de janeiro, por telefone, foi dada a aprovação final.

\section{Tia Surica - Iranette Ferreira Barcellos}

A rede de mulheres de cada Velha Guarda permitiria dar atenção às particularidades do discurso feminino, observando as marcas de cada tipo de narrativa pelo viés do gênero. Tia Surica é a pastora mais antiga em atividade na Velha Guarda da Portela, o que fundamentou a sua escolha como colaboradora.

O Dicionário Cravo Albin afirma que Tia Surica “é uma das legendas vivas da escola de Madureira, além de cozinheira afamada. Organizou em sua casa rodas de samba regadas a quitutes e feijoadas, sempre freqüentada por pessoas da comunidade e artistas da MPB”30.

\footnotetext{
${ }^{30} \mathrm{http}: / / \mathrm{www}$. dicionariompb.com.br/surica. Último acesso em 20 jan. 2011.
} 
O primeiro contato com Surica foi feito por telefone, marcando a entrevista para o dia 16 de julho. No caminho para Madureira, a bordo do trem, telefonei confirmando que chegaria dentro de pouco tempo, mas fui surpreendida com a notícia de que houvera uma confusão e ela não estaria mais pronta para me receber. Ela concordou com a minha ida lá, apenas para que eu já aprendesse o caminho, já que estava perto. Recebeu-me com muita simpatia e decidimos fazer a entrevista na segunda-feira seguinte, dia 19 de julho. Ao telefonar na segunda-feira, antes de pegar o trem, novamente um desencontro de informações parecia ter acontecido. Combinamos que eu chegaria uma hora depois do que tinha anotado, e que seria uma entrevista rápida.

Apesar de ter sido breve, sua narrativa traz novos elementos em relação às demais, principalmente pela referência à feijoada e à festa.

Esta foi a única entrevista que, transcriada em dezembro de 2010 e enviada por correio, não foi ainda validada.

\section{Serginho Procópio - Sérgio Procópio da Silva}

Pareceu importante, já que não seria possível entrevistar todos os integrantes da Velha Guarda, escolher pessoas que tivessem características "representativas". Assim, Serginho Procópio entrou na pesquisa por ser o mais jovem dos integrantes masculinos da Velha Guarda da Portela, que ingressou no grupo em substituição a seu pai, o falecido Osmar do Cavaco.

Além de cavaquinista, é também compositor, tendo sido gravado por Zeca Pagodinho, Beth Carvalho e Fundo de Quintal, entre outros, e fez em parceria com Casquinha $O$ último recado. "A incorporação de Serginho à Velha Guarda é mais uma demonstração de que os laços familiares exercem papel importante na perpetuação das tradições portelenses", afirmam Carlos Monte e João Baptista M. Vargens (2001, p. 133).

O contato inicial com Serginho se deu por telefone. Expliquei os propósitos da pesquisa e marcamos a entrevista, gravada no dia 20 de julho de 2010 em sua casa, em Bangu.

O ponto de partida para a sua narrativa é uma viva memória como criança. Esse parece ser o tom predominante mesmo quando não se trata de rememorar a infância: Serginho fala com uma delicadeza inocente e sempre do ponto de vista de um aprendiz. Essa condição foi evidenciada inclusive pela sua apreciação da entrevista transcriada: em tom de surpresa, afirmou que achou interessante a sua história.

A validação aconteceu por telefone no dia 4 de janeiro de 2011 , tendo sido feita uma única correção pontual à transcriação enviada por correio. 


\section{Balbina - Balbina de Oliveira Thomé}

Foi Zé Luiz quem forneceu os contatos de Balbina e Lindomar, as duas pastoras da Velha Guarda do Império Serrano que também passaram a ser colaboradoras deste projeto. A vontade de entrevistar Balbina vinha de quando conheci o CD Império Serrano: um show de Velha Guarda (2006) e li o parágrafo biográfico em que se destacava que a sua família era a dos fundadores da escola. Sua narrativa, portanto, interessava-me como mulher, mas também como herdeira direta da tradição familiar.

Contatei Balbina por telefone e a entrevista foi realizada em sua residência, no Irajá, no dia 21 de julho de 2010. Sua filha Jussara acompanhou a entrevista, mesmo quando não estava no mesmo ambiente que nós. Era comum, em alguns momentos, quando Balbina elevava um pouco a voz procurando uma confirmação, escutar a voz de Jussara de dentro da casa, respondendo.

$\mathrm{O}$ encontro com Balbina foi fascinante. Ela falava com uma alegria e um vigor fora do comum, e cantou muitos trechos de sambas na medida em que "puxava" suas lembranças, com uma voz muito bonita. Estava com o fêmur quebrado, esperando para receber uma prótese. Imaginei que estivesse sentido muita dor, mas sua firmeza e vibração não deixavam espaço para qualquer sentimento de pena. Era pura admiração.

Um dos momentos mais tristes da pesquisa foi a notícia de seu falecimento, quase dois meses depois da entrevista gravada, no dia 14 de outubro de 2010, por negligência ou imperícia médica. Apenas quando telefonei para informar que em breve enviaria a transcriação para aprovação, em dezembro, foi que Jussara me deu a notícia. A validação foi feita com Jussara, no dia 8 de janeiro de 2011.

Além da erudição de Balbina e da desenvoltura com que citava sambas e episódios da história do Brasil, principalmente na segunda metade do século XX, pareceu-me curiosa a maneira como ela dizia "jogar" o samba na quadra. Isso dava uma condição muito material para o samba, que ela dominava e tinha o poder de difundir. Balbina não apenas viveu no samba ou para o samba, como também os sambas-enredo e sambas de deboche pontuaram sua memória e pareceram funcionar como os fios de sua coerência.

O último que se ouve de Balbina na gravação é a sua voz colorida acompanhando a de Jamelão na gravação que fez questão de me mostrar, compartilhando a beleza de Primavera (Cântico à Natureza), dos mangueirenses Alfredo Português, Nelson Sargento e Jamelão.

Prefiro esse final para ela. 


\section{Áurea Maria - Áurea Maria de Almeida Andrade}

Adotando para a rede de mulheres da Velha Guarda da Portela a mesma orientação pela qual escolhi "o mais novo" e "o mais antigo" dentre os homens, pareceu lógica a escolha de Áurea Maria, filha e parceira do compositor Manacéa, a mais jovem das pastoras do grupo. Seu contato foi fornecido por Serginho Procópio.

A entrevista foi bastante curta, em decorrência do lugar onde nos encontramos: o Circo Voador, na Lapa, na madrugada do dia 27 de julho de 2010. A Velha Guarda da Portela esperava para fazer uma participação no show de Moyseis Marques, então além do barulho, havia a sensação de que a qualquer momento eles poderiam ser chamados ao palco. Mesmo sem ter tido a oportunidade de fazer uma entrevista mais demorada, essa narrativa trouxe elementos importantes.

Áurea foi também muito doce e receptiva, demonstrando de alguma forma a condição da humildade de aprendiz que percebi em Serginho. Sua entrevista transcriada foi validada por telefone no dia 7 de janeiro de 2011, quando solicitou correções que aperfeiçoavam o texto, eliminando algumas das marcas do discurso falado.

\section{Lindomar - Lindomar Ferreira Fraga}

Lindomar apareceu como uma voz complementar às demais vozes femininas e foi a última colaboradora entrevistada para a pesquisa. Não sendo "geneticamente" vinculada à escola, mas tendo sido escolhida para integrar a Velha Guarda musical, tive interesse em escutá-la para buscar esse outro tipo de vivência, que não se inscreve na herança "natural".

Entrei em contato por telefone e Lindomar se dispôs a me receber em sua residência, na Taquara, já no dia seguinte, 27 de julho de 2010. A entrevista foi gravada em meio a tecidos, máquinas de costura e uma grande mesa, em que Lindomar espalhou algumas das matérias e fotografias que conserva sobre a Velha Guarda.

Sua narrativa é ativada pela costura, com que trabalha desde criança. Ao falar dos desfiles, chamou atenção a importância atribuida às fantasias que ajudou a confeccionar para os desfiles. Sua transcriação foi validada por telefone no dia 10 de janeiro de 2011. 
O mapa abaixo representa os trajetos percorridos ao longo da pesquisa, para a gravação das entrevistas. Estão representadas as onze localidades onde aconteceram as entrevistas, sendo o ponto de partida o bairro de Laranjeiras.

Os pontos 3 e 4 são conectados diretamente porque foi esse o trajeto: no mesmo dia, saí de uma entrevista, no Engenho de Dentro, para outra, na Cinelândia.

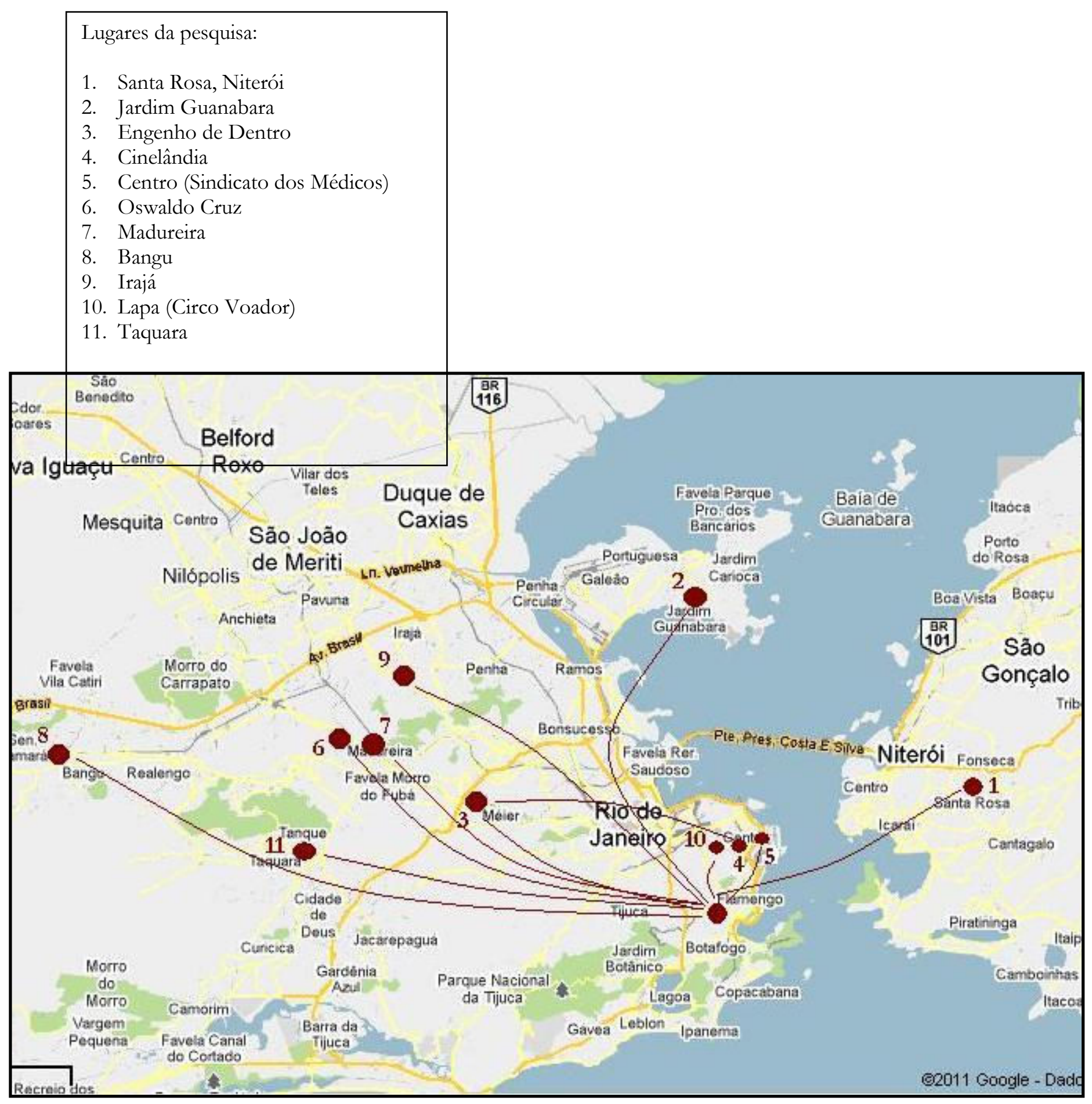




\subsection{Análise}

Observando as narrativas a partir de uma abordagem que poderíamos dizer "interna" para não cometer o sacrilégio acadêmico de chamar de "internalista" - pode-se apontar traços presentes em cada uma, fazendo-as "dialogar", para em seguida delinear as feições do que pode ser chamado de memória coletiva, ou, mais precisamente em alguns casos, percepção coletiva.

Aqui o "efeito entrevista" deve ser avaliado: aquilo que cada um escolheu dizer pode estar relacionado com a sua percepção do que seria o interesse principal desta pesquisa. Sem ignorar o fato de que a presença da pesquisadora instiga essa organização homogênea dos discursos, pretende-se identificar as especificidades da construção das narrativas individuais e das relações de cada colaborador com a sua escola.

Se fosse preciso sintetizar em poucas palavras ou imagens os momentos mais expressivos das entrevistas, o fio particular que me pareceu marcar as narrativas seria, na de Monarco, o "baú" musical; na de Serginho, a deferência; na de Tia Surica, a feijoada; na de Áurea, a memória; na de Wilson, o atabaque do candomblé; na de Ivan Milanez, a inovação não reconhecida; na de Lindomar, as fantasias; na de Balbina, os sambas; na de Zé Luiz, a resistência; na de Noca, a convivência; e na de Zé Katimba, a superação. Pensei essas associações a partir da percepção muito forte, no caso de Lindomar, de que a memória se ativa pela lembrança das fantasias, que ela descreve em detalhes, associando à satisfação com relação à Velha Guarda o fato de ficarem todos impecáveis, bem vestidos. Essa marca de estar "bem vestido" é enunciada em outras falas, mas Lindomar parece organizar-se, de fato, pelo universo da costura. Não são, por certo, as únicas marcas das narrativas, e evitarei reduzi-las: trata-se, antes de mais nada, de histórias de vida ricas, que prefiro não limitar demais nestas análises. Mais adiante, na Parte II, as narrativas aparecem na íntegra, para permitir uma apreciação menos fragmentada.

Um primeiro traço comum aos colaboradores é que todos nasceram em contextos sócio-econômicos localizados entre a classe média e a pobreza, sendo predominantes as histórias de vida que se iniciam em estratos considerados "classe média baixa" "31. Cinco deles

\footnotetext{
${ }^{31}$ Trata-se de uma definição complicada, mas que serve para entender que em grande parte dos casos parece ter havido, se não uma efetiva "ascensão", pelo menos melhoria das condições de vida. Por exemplo, quase todos os colaboradores têm casa própria e, quando não estão aposentados, estão vivendo de profissões escolhidas (músicos ou, no caso de Lindomar, costureira). As denominações eram atribuídas pelos próprios colaboradores ao falarem especificamente da infância: "pobreza", "pobreza com dignidade", "humilde", "vida com dificuldade" e "não tinha muita regalia" são algumas maneiras de expressar essa condição. O extremo mais
} 
perderam o pai (Ivan Milanez e Zé Luiz) ou pai e mãe (Tia Surica, Balbina e Zé Katimba) ainda durante a infância. O mundo da música, ou especificamente o do samba e do carnaval ainda que não fosse "para crianças" -, aparece como referência já nos primeiros anos de vida de todos. Lindomar, Noca e Zé Katimba, apesar de terem nascido fora do Rio de Janeiro, tiveram contato com o samba até por volta dos 10 anos. Assim, todos aparecem como pessoas que, desde muito cedo, tiveram referências musicais mais tarde transformadas em vivências do samba.

Serginho Procópio: Minha história na música vem desde pequenininho; meu pai era músico, meu avô também foi músico, compositor de chorinhos.

Tia Surica: Meu pai morreu, eu estava com 12 anos; quando minha mãe morreu, eu estava com 7 anos. E eles é que me levaram pro samba. Comecei a sair na Portela com 4 anos, e é onde eu estou até hoje. Fui carregada por eles...

Aurea Maria: A minha casa sempre foi uma casa festiva. Meu avô participava de um grupo que tocava chorinho, e nos finais de semana ele reunia esse grupo em casa. Aos domingos, eu já amanhecia ao som do bandolim.

Wilson das Neves: Digo sempre que nasci imperiano, apesar de o Império ser mais novo que eu: em 1947, quando foi fundado, eu tinha mais ou menos 8 anos, mas não era muito ligado. Minha mãe se tornou baiana da escola, então aquilo veio, só se falava em Império Serrano e acabei gostando, como clube de futebol.

Ivan Milanez: A minha trajetória no samba começou praticamente de berço, porque minha mãe não era passista nem nada, mas ela fazia fantasia para o Império Serrano.

Lindomar: Assim que eu cheguei de Recife, com 11 anos, fui para o Império. Era lá em cima. Lembro que era numa casa na Serrinha, a casa da Tia Eulália. Aí, às vezes, quando minha tia ia pra lá, eu ia junto.

Balbina: Ah, mas eu ficava doida quando se falava no Império Serrano, lá no colégio... Mas a gente não podia nem olhar, negócio de samba, porque era religioso, católico, não é? Eu ainda novinha, com 10 anos, não podia desfilar, porque antigamente criança não desfilava. (...) Quando eu fiz 14 anos é que eu pude sair, quando saí do colégio interno, com o primário completo.

Zé Luiz do Império: Nos meus dez primeiros anos de vida, morei em Santa Teresa e era muito próximo ao carnaval do Rio. Era só descer com o bondinho, em cinco minutos eu já estava na Avenida Rio Branco, no Tabuleiro da Baiana, e tudo acontecia ali.

pobre seria o da infância de Zé Katimba, que dividia a água para beber com o gado, imagem que evoca tanto na entrevista por mim gravada quanto no livro de Fernando Paulino (2009). 
Noca da Portela: Eu não sou carioca, sou de Minas Gerais - Leopoldina, Minas Gerais - e fui morar no bairro do Catete, no Rio de Janeiro, ainda criança, com 5 anos. Ali tinha uma escola de samba e com 14 anos eu concorri pela primeira vez, e não é que eu ganhei?

Zé Katimba: Era para eu fazer forró, mas tive contato com o samba. Descendo o morro para pegar água na lata, carregando a lata d'água na cabeça, feito a Maria - "lá vai Maria..." - a gente, a molecada, ia batucando na lata, cantando samba - esse foi meu primeiro contato e a partir dai nunca mais eu me afastei do samba, nem o samba de mim.

Ao dizerem que foram levados para o samba, ou que a trajetória no samba começou, ou que nunca mais se afastaram do samba, Tia Surica, Ivan Milanez e Zé Katimba deixam entrever também a idéia do samba como algo mais que um gênero musical. José Sávio Leopoldi define:

O mundo do samba é expressão corrente que circunscreve um conjunto de manifestações sociais e culturais que emergem nos contextos em que o samba predomina como forma de expressão musical, rítmica e coreográfica. Daí dizermos, inicialmente, que o samba é a matéria-prima desse universo (...) (LEOPOLDI, 1978, p. 34).

É ainda Leopoldi quem identifica que a participação constante em atividades ligadas ao samba se traduz pela expressão da intimidade. Ao observar diferentes formulações dadas por participantes de escolas de samba com relação à categoria "sambista", Leopoldi indica que o contato intenso e contínuo seria a base para o conjunto de relações sociais circunscritas no mundo do samba (p. 42). Essa questão é importante, porque a vivência da escola parece ser determinante para o ingresso na velha guarda, que seria como uma coroação, um reconhecimento, pela trajetória de intenso convívio na escola de samba, considerada o locus por excelência para a sociabilidade do mundo do samba.

Em termos da formação e das trajetórias profissionais, seria difícil entender o grupo usando categorias estabelecidas a partir da ocupação, que não significa, em muitos destes casos, aperfeiçoamento da formação e crescimento numa profissão escolhida ou pela qual se tinha inclinação. Serginho Procópio, Áurea Maria, Wilson das Neves e Lindomar, respectivamente músico, assistente social, músico e costureira, apresentam as trajetórias profissionais mais "lineares" nesse sentido, em que parece ter havido uma conjugação de formação e escolha vinculadas a vocação. Áurea Maria é a única dos colaboradores que concluiu o ensino superior.

Há ainda, no grupo de colaboradores, dois ex-funcionários públicos (Balbina e Zé Luiz), uma costureira (Lindomar), dois ex-feirantes (Monarco e Noca) e três trabalhadores informais que tiveram diferentes empregos (Tia Surica, Ivan Milanez e Zé Katimba). Essa 
caracterização não deve ser vista como uma marca "absoluta": no caso de Balbina, por exemplo, houve o trabalho na fábrica de tecidos ou em "casa de família"; Monarco foi também contínuo; Zé Luiz começou trabalhando numa oficina de metalurgia; e por aí vai. O que parece importante notar é que em algumas das narrativas, na falta de uma formação profissional, ou de uma educação formal, considera-se a escola de samba ou as passagens difíceis da vida como importantes para a formação moral, muito valorizada na apresentação pessoal de quase todos. Talvez esse elemento só não apareça explicitamente na fala de Lindomar, que sintomaticamente é quem se apresenta como mais "distante" da personalidade de sambista. Para os demais, a vida ou a escola de samba, aliadas a uma predisposição individual para prestar atenção ao ambiente, aparecem como responsáveis por uma sólida formação moral. Deus também aparece muitas vezes vinculado ao "não sei quê", como sendo fonte de força ou talento.

Esse cultivo de valores como a honestidade, a consideração e a humildade, entre muitos outros, pode estar associado à questão da adequação ao grupo: fica evidente que, para ingressar na ala de compositores da Portela, por exemplo, devia-se aprender o "procedimento", ter "respeito", conhecer a história; mais tarde, para fazer parte das Velhas Guardas tanto da Portela como do Império Serrano, ter uma história na escola seria a chave fundamental.

Além dos caminhos que levam cada um ao samba, quase sempre relacionados com a família ou com a proximidade física de escolas ou blocos, emerge das narrativas uma relação que se distingue por um duplo movimento: o indivíduo chega ao samba, mas é também levado por ele a lugares que não conheceria de outra forma. Ivan Milanez, Lindomar, Noca da Portela e Zé Katimba explicitam isso, atribuindo à música ou ao samba qualidade de pessoa:

Ivan Milanez: ... a música me levou a alguns lugares que acho que se eu não fosse músico não teria chegado... Não trabalharia com pessoas, nem alcançaria lugares que alcancei, nessas minhas andanças ai. Com o dinheiro, por mais dinheiro que eu tivesse, eu não batia com essas pessoas que eu consegui trabalhar, muita gente com grana não conseguiu entrar.

Lindomar: O samba me ajudou muito, não só na Velha Guarda, porque no samba nós temos muitas oportunidades de conhecer lugares onde o pessoal comum não vai. Por exemplo, fui a teatros, fui a shows, convidada, assim... Porque o pobre mesmo não anda em determinados lugares, a não ser que seja convidado. Então com o samba, a gente vai.

Noca da Portela: Hoje eu tenho coisas, essa casa é minha, comprei. Foi o samba que me deu. Tudo isso que está aqui, essa familia grande, essa coisa toda, tudo isso, esses troféus, essas medalhas, está faltando espaço na parede. Eu não posso ser ingrato ao samba, sabia? 
Zé Katimba: O samba e a mulher têm me dado as maiores alegrias da minha vida: através do samba conheci pessoas que me deram filhos, e filhos que fazem samba, que são da música também. Sou uma pessoa muito feliz. Quando fico um pouco triste, vou fazer um samba.

À formação da personalidade de sambista corresponderia também a capacidade de discernir entre "bom" e "mau" samba, defendendo a cultura "pura" contra as influências externas: tornar-se um autêntico sambista dependeria da legitimidade conferida por quem veio antes e permitiria que o indivíduo passasse a avaliar quem mais poderia ingressar nessa "Academia", como diz Noca. Ivan Milanez ironiza a entrada em escolas, casas de samba e projetos como o Pagode do Trem de pessoas "formadas", dizendo não se lembrar de os antigos da escola de samba terem tido que adquirir educação formal.

Outro corte que interessa nestas considerações é o de gênero, que foi o definidor das duas redes principais formadas ao longo da pesquisa. A via de entrada das mulheres entrevistadas em suas escolas difere da dos homens: as quatro cresceram no ambiente das escolas, tendo acontecido o primeiro contato entre os 4 e os 14 anos. Os homens entraram pelo trabalho como compositores ou ritmistas, desempenhando variados papéis nas escolas, em poucos casos tendo sido levados "exclusivamente" pela família ${ }^{32}$.

O tom vital, como se chama na história oral a espécie de "mensagem principal" enunciada em cada discurso, ajuda a perceber as entrevistas naquilo que têm de particular. $\mathrm{Na}$ entrevista de Monarco, por exemplo, a idéia que me pareceu mais marcante foi a do samba "puro", que seria a base para uma identidade que é missão da Velha Guarda defender; na de Serginho Procópio, ficou evidente a grandeza atribuída à Velha Guarda, aos antigos, com quem os que chegaram depois devem aprender, cujas "lições musicais" devem transmitir; na de Tia Surica, destacava-se a força e a autonomia com que identifica a sua trajetória; na de Áurea Maria, de forma semelhante à de Serginho, aparece a condição de aprendiz. Wilson das Neves critica a descaracterização resultante das transformações no samba, enfatizando que modernizar não significa deturpar; a fala de Ivan Milanez parece ser marcada pelo tom de "acerto de contas", aliado à idéia de que do talento e do reconhecimento não decorreu o retorno financeiro; a entrevista de Lindomar parece a de alguém que observa mais do que participa ativamente, sendo os elementos centrais o trabalho e a vontade de aproveitar a vida; a de Balbina relaciona-se com a quantidade de informação e conhecimento que ela detém sobre a escola, dando-lhe ares de erudita e testemunha, que viu a história acontecer. Zé Luiz

\footnotetext{
${ }^{32}$ Seria importante aprofundar essa observação aliando-a às formas de socialização típicas da vida do subúrbio, onde quase todos os colaboradores residiram ou residem.
} 
aparece associado com a consciência e a defesa de valores independentes da coesão do grupo, o que se associa com a fundação da escola de samba Quilombo; Noca da Portela fala como alguém da velha guarda do samba, defendendo que tanto a escola precisa de sambistas bem "formados" - ou seja, que tenham passado pelas diversas etapas de convivência e aperfeiçoamento junto aos mais velhos - como os sambistas precisam de uma escola que lhes ensine a ser sambistas; e Zé Katimba aparece como sambista bem-sucedido, que enfrentou todo tipo de dificuldade graças ao samba, à inspiração (a mulher) e ao seu talento (Deus).

É comum a todos o diagnóstico de que a escola de samba piorou, mas os principais “culpados” variam: o poder do dinheiro (Monarco, Wilson das Neves, Zé Luiz e Zé Katimba), a centralidade do samba-enredo (Serginho Procópio, Ivan Milanez, Zé Luiz e Noca da Portela), a perda do aspecto familiar (Tia Surica) e a chegada dos banqueiros de bicho (Balbina) são alguns. Um dado curioso foi que, em mais de uma oportunidade, ao validar as transcriações, referências nominais a banqueiros de bicho foram suprimidas. Apenas alusões gerais permaneceram. A referência a traficantes de drogas, que não apareceu nas entrevistas, mas sim em conversas informais, é percebida como um elemento preocupante: em determinadas comunidades de sambistas, os traficantes não teriam - como alguns banqueiros de bicho antigos tinham - respeito pelos sambistas, fazendo-lhes ameaças. Uma situação relatada foi a de um traficante que teria abordado um sambista sugerindo querer conhecer melhor sua filha, o que o teria levado a abandonar quase imediatamente a comunidade. A esse tipo de situação estaria correspondendo a evangelização de cada vez mais pessoas ligadas ao samba, como forma de "proteção", já que os evangélicos são poupados desse tipo de intimidação.

Quase todos comentam de forma negativa os desfiles das últimas três décadas, principalmente no que se refere àquilo que é valorizado pela mídia, alguns abordando também a questão da rapidez e da cronometragem.

Wilson das Neves: Coisas importantes da escola a televisão não mostra, só mostra o que interessa a ela, o artista da novela, pra promover a novela; não mostra mestre-sala e porta-bandeira, a dança deles, o momento mais importante do desfile. E a bateria é o que segura, não tem baile sem orquestra, tem? Se a bateria parar, vira o quê? Mas eles dão valor à rainha de bateria. Será que lá no morro não tem uma crioula que era só dar um banho de loja nela e botar ela lá? Na hora que ela pode ser rainha, ela vira escrava de novo.

(...)

Escola de samba desfila feito boi: toc-toc-toc-toc-toc, e vamo, vamo, vamo, como relógio, as escolas não evoluem. Na evolução, as alas entravam umas nas outras, isso é que era evolução, e não tem mais. Então pra mim acabou, ou melhor, virou outra coisa. É tudo muito igual, a única coisa que muda de uma escola para outra é a cor da bandeira. Antigamente se uma escola era 
verde e branco, tudo era verde e branco. Um tom de verde mais claro, mais escuro, mas era tudo verde e branco. Hoje é um arco-íris...

Balbina: Eu não acho graça naquilo. Eu vou porque eu sou Império e a minha voz faz falta. A escola de samba, não pensa que é só roupa bonita e bunda, não. É harmonia, a pessoa cantar.

Zé Luiz: ... a ala das baianas, por exemplo, é uma ala que está entrando em extinção, porque não tem mais baiana com velocidade para disputar, desfilar numa correria de samba.

(...)

Hoje todo mundo quer ver é bateria e rainha de bateria. É o que interessa à mídia. É tudo a mesma coisa (...). [É] o que o turista quer ver. A ele não interessa que a ala tal tenha 50 anos, ou que a baiana, ou que aquele lá é o Seu Zé das Couves, que fez o primeiro bloco para virar escola...

Talvez um dos pontos mais ricos de se discutir seja o da superioridade do antigo em relação ao novo no âmbito das Velhas Guardas, movimento que se opõe frontalmente à idéia da inovação constante, que marca o modo de produção capitalista. Ao revalorizar o antigo, que enfrentou a incompreensão, a censura e o preconceito, cria-se no presente um campo de disputas que opõe "velho" a "novo" como "desinteressado" a "comercial", "de fora" a "de dentro" da escola, ou "amor" a "dinheiro". Como voz que ecoa o passado, que lhe dá legitimidade para cobrar uma dívida simbólica, a Velha Guarda seria a portadora da verdade do samba. Nesse contexto, aparecem também as alusões à riqueza de linguagem, à beleza da poesia, em oposição às limitadas condições materiais ou à falta de educação formal ${ }^{33}$. A citação às rimas ricas como sinais de qualidade aparece nas narrativas de Monarco e Noca da Portela.

Monarco: Podem fazer coisas lindíssimas aqui, no universo deles, que nós também não vamos fazer, compreendeu? Mas eles não vão fazer igual a um compositor ali que pouco freqüentou bancos escolares, mas que tem aquela linha, que parece que é uma dádiva divina, ajudada por Deus.

(...)

Cartola, que pouco estudou, pra fazer "as rosas não falam, simplesmente exalam" - olha que rima rica - "o perfume que roubam de ti", uma coisa linda.

Noca da Portela: Agora os caras fazem samba com 22 linhas, mas ninguém canta mais porque não faz sentido. É rir pra não chorar. Não tem melodia, não tem sentido, não tem poesia, não tem nada, ai só serve pro cara passar no desfile, depois na quarta-feira de cinzas, alguém pede:

- Canta o refrão do teu samba, da tua escola?

-Ih, rapaz, esqueci, não lembro!

\footnotetext{
${ }^{33}$ Esse discurso é muito cristalizado na história do samba, e parece fundado em uma percepção quase mítica do sambista como nobre de alma, mas rodeado pela pobreza material, talvez por isso mesmo aproximando-se da "pureza" e do verdadeiro "valor", merecedor de recompensa simbólica. Essa percepção, ao mesmo tempo em que valoriza o sambista, conforma-o à situação da pobreza.
} 
(...)

Lógico, tem que harmonizar a letra! Ter noção de rimas, e se possivel rimas ricas. Tem que ter uma noção musical, pra fazer uma melodia correta, para não criar um choque entre duas notas, entendeu? A poesia bem rimada, com sabedoria; precisa saber usar as palavras.

Serginho Procópio: O samba de terreiro é aquele samba livre (...). E hoje em dia as escolas de samba não têm isso, é muito só ligado ao sambaenredo. As coisas só acontecem na escola de samba quando começa negócio de samba-enredo.

Tia Surica: O samba perdeu um pouco a sua essência. Porque naquela época, o samba era uma família.

Wilson das Neves: É marchinha! Primeira, segunda e acabou, vem o refrão... É fácil, todo mundo aprende, mas não guarda. Aprende na hora, pra cantar, mas na hora de lembrar, vai cantar o quê? O de 1950.

Ivan Milanez: Naquela época, os caras que faziam samba-enredo, a gente via aqueles caras fazendo realmente com carinho, e um compositor não saía de uma escola para ir pra outra. Depois que veio esse problema do LP de samba-enredo é que mudou muita coisa. Veio história de cronometragem, que a escola não tinha cronometragem para desfile, o pessoal saía descontraído, com prazer, ficava lá dando volta. Aí passou a ter...

(...)

Infelizmente, dizem que a mola-mestra do mundo é o dinheiro, e o dinheiro mexe com as pessoas. Começou o compositor também a gravar com outros interesses.

Balbina: A escola de samba, agora, é o dinheiro, é isso. Dinheiro e a posição, de aparecer. A pessoa não está na escola porque gosta da escola, não, quer aparecer! Eu não, gosto da minha escola, foi lá na minha casa que eles fundaram, eu não quero aparecer! Se vem uma câmera de televisão, eu saio correndo! E eu digo, meu Deus, o que é isso? Nada, agora... É tudo vaidade. Não é mais aquilo de dentro da gente.

(...)

Escola de samba, antigamente, os sambas ficavam na história. Agora você não sabe o samba-enredo do ano passado.

Zé Luiz do Império: A freqüência nas escolas de samba começou a ser só a partir de junho, voltada para o samba-enredo. Mais um motivo para cada vez afastar mais o pessoal da comunidade. Não fazia mais sentido você ir para as escolas de samba, porque sabia que tudo estava voltado para o enredo ser escolhido. Começou aquele negócio de disputa de samba-enredo.

Zé Katimba: Antigamente o samba não dava dinheiro, e era feito tudo na base do amor. Quando não tem dinheiro, a coisa fica um pouco mais... Controlada.

A manipulação da disputa de samba-enredo de hoje merece registro, aparecendo uma percepção praticamente idêntica de uma "receita de fazer samba" na narrativa de vários colaboradores: 
Serginho Procópio: ... nem todo mundo que compõe samba-enredo, que tem o seu nome lá, nem todo mundo compõe... São seis, mas dois correm atrás da grana, dois fazem o samba, os outros são responsáveis pela torcida, entendeu?

Wilson das Neves: Não é mais aquilo, e nem vai voltar atrás, se já tem escritório fazendo samba. De encomenda! Samba hoje é encomenda.

(...)

Porque não é compositor, é comprôsitor.

Ivan Milanez: Aí é que começou a aparecer parceria com o fulano que era o dono fábrica de sabão, aí botava, Seu Manoel Português, dono da padaria, agora é parceiro. E um cara, também, por si só, não tinha outro jeito. Os outros entravam, ele também tinha que entrar.

(...)

Então hoje em dia os critérios são diferentes. Ou vocêfaz ou não faz, porque ou tem que ter um cantor bom, ai tem que ter dez ônibus... E você não tem dinheiro... Na época desse pessoal anterior, acho que não existia pagamento para se inscrever samba-enredo.

Noca da Portela: Ai o Cabana, que era compositor do samba concorrente, chegou, alugou dois ônibus, encheu a quadra lá da Portela, deu dinheiro a eles...

Zé Katimba: Para fazer um samba, ficou mais ou menos assim: dois compositores se juntam e fazem o samba. Ai entra um sujeito para pagar a carne e a bebida, para fazer festa nas comunidades, nos bares, para juntar uma torcida e levar para a quadra. Entra outro para pagar os prospectos e o aluguel dos onibus; outro que paga o ingresso, a entrada do pessoal na quadra e a cerveja lá dentro. E todo mundo entra na composição. Então hoje é normal você pegar um samba e ter seis, oito compositores, porque aqueles que entram, entram pra aparecer.

Noca da Portela e Serginho Procópio apontam para soluções que poderiam ajudar a retomar os princípios e valores das escolas, que passam pelo incentivo à convivência entre antigos e novos compositores, a valorização do samba de quadra e a organização de feijoadas $^{34}$.

Serginho Procópio: Agora está até mudando, por causa desse negócio das feijoadas. Até fomos nós que começamos com isso, e a feijoada da Portela foi justamente para isso, para a gente poder cantar os sambas de terreiro, para não ficar morto, e acabou que até esse processo as escolas de samba foram jogando de lado, e já estavam desaparecendo outras coisas, que eram típicas das nossas culturas.

Tia Surica: Ah, porque o samba, sem uma comida e sem uma bebida, e uma roda de samba bem legal, não é samba, não é?

\footnotetext{
${ }^{34}$ As feijoadas merecem um estudo aprofundado tanto do ponto de vista da sua produção quanto das regras e valores nela envolvidos, a distribuição dos papéis e o tipo de socialização que proporcionam.
} 
Noca da Portela: Infelizmente não está mais presente nas escolas essa tradição. Samba de quadra era uma aprendizagem pro cara ser realmente um grande compositor.

(...)

Pra você fazer o samba-enredo, nas escolas dos tempos idos, você tinha que passar pelo samba de quadra. E através do samba de quadra, tinha conhecimentos da escola.

\section{Velha Guarda da Portela}

As entrevistas de Monarco, Serginho Procópio, Tia Surica, Áurea Maria e Noca da Portela, ao serem observadas em conjunto, demonstram uma coesão muito forte com relação ao pertencimento à Portela e à Velha Guarda, que aparece como uma realização central em suas vidas.

Monarco: Devo muito à Portela, porque foi nela que eu iniciei meus primeiros passos...

Serginho Procópio: Então agora eu fico vendo, eu participava disso aí tudo e não sabia qual era o valor que tinha; já gostava, mas não sabia que isso ia ser a minha vida. É muito grande, poxa...

Tia Surica: Devo muito à Velha Guarda da Portela, e ao nosso saudoso Manacéa, que foi quem me encaminhou para a Velha Guarda. Abriram-se as portas, hoje eu tenho um disco gravado, gravo com vários artistas, e a Velha Guarda pra mim é tudo, sabe?

Aurea Maria: ...participar da Velha Guarda da Portela é um orgulho muito grande pra mim. Só tenho a aprender a cada dia.

Noca da Portela: Eu aprendi muito com a Velha Guarda, quando eu cheguei lá estavam se organizando, então eu tive a honra, o prazer e a felicidade de conhecê-los no auge da sua força de compor.

Isso pode resultar, como foi dito antes, do "efeito entrevista", mas pretende-se avançar nas especificidades que qualificam essa centralidade para cada um. Monarco, por exemplo, associa-se a uma linhagem de continuadores da tradição da Velha Guarda. Sua entrada na ala de compositores da escola acontece por meio, primeiro, da observação dos mais velhos, depois pela aceitação por parte dos antigos:

Monarco: ...eu fui me aperfeiçoando ali, menino, mas tinha que me aperfeiçoar mais, vendo aqueles bambas fazendo aquelas coisas lindas, na roda, cantando, então eu ficava de longe, olhando, sonhando, armazenando na minha cabeça o desejo de um dia fazer um samba para a Portela. Isso veio acontecer aos meus 17 anos, quando fiz o meu primeiro samba, e fui aprovado pelos bam-bam-bãs (...). Dali é que as coisas foram começando, ai eu fui me tornando parceiro daqueles antigos... Aqueles grandes sambistas dali, grandes compositores, foram me dando primeiras partes pra botar a segunda, eu botava direitinho, fui me tornando parceiro dos que eu olhava 
assim de longe, e admirava, então o sonho foi virando realidade e, graças a Deus, se hoje eu tenho alguma coisa, na vida artística, o meu aprendizado foi com eles.

(...)

Ventura, que foi o primeiro responsável pela Velha Guarda (...). Depois do Ventura, passou para a mão do Manacéa, do Manacéa passou para a minha mão.

O fato de ter sido ele o mais jovem compositor da Velha Guarda a ingressar no grupo como compositor - Serginho Procópio e Áurea Maria entraram principalmente pela condição de substitutos ou representantes dos pais -, aliado a um profundo conhecimento do repertório dos "antigos", lhe dá essa ascendência sobre os demais. Ao iniciar a sua narrativa, parece ter sido predestinado à Portela:

Monarco: Depois fui morar em Oswaldo Cruz e as coisas se encaixaram melhor, porque ali pertinho tinha a Portela. Eu já ouvia falar de Oswaldo Cruz através do samba do Noel Rosa, da Aracy de Almeida, já rolava alguma coisa com o nome do Paulo da Portela, então, quando eu cheguei em Oswaldo Cruz, eu me senti, assim, como se tivesse chegado... Num lugar certo.

Outra forma de se aliar aos sambistas dos primeiros tempos se dá ao citar, na letra do seu samba Velhas companheiras, uma expressão cunhada por Cartola, além de responder, tanto em letra quanto em melodia ${ }^{35}$, à composição $O$ meu nome já caiu no esquecimento, de Paulo da Portela.

Para Tia Surica, o momento mais decisivo na escola é a sua participação da apresentação de Memórias de um sargento de milícias no carnaval de 1966. Ela identifica naquele momento o começo de uma participação como cantora na escola, que culminaria com a entrada na Velha Guarda, em 1980. Surica registra que foi graças à Velha Guarda que iniciou sua carreira solo, nos anos 2000.

Já Serginho Procópio e Áurea Maria vinculam o ingresso na Velha Guarda ao falecimento dos pais, o que indica uma relação ao mesmo tempo mais independente e mais previsível com a Velha Guarda: independente por serem mais jovens; previsível porque, dada a sua relação de berço com o grupo e o envolvimento com a música desde cedo, seriam os "candidatos ideais", pelo menos no que se refere à compreensão sobre a missão da Velha Guarda e à seriedade necessária para aceitar representá-la.

Nas entrevistas de Serginho Procópio, Tia Surica e Áurea Maria, Monarco aparece respectivamente como guru, referência e líder:

\footnotetext{
${ }^{35}$ Apesar de não ter sido possível desenvolver a análise para além da letra na presente dissertação, vale deixar registrada a intenção de fazê-lo futuramente. No caso específico da resposta a $O$ meu nome já caiu no esquecimento, basta ouvir as duas melodias (CD anexo).
} 
Serginho: O Monarco tem uma memória... Que é impressionante, ele sabe o ano que foi e tudo. Daqui a pouco ele força a cabeça dele aqui, lembra a música, lembra um pedaço, daqui a pouco ele vai lembrar a música toda.(...) Naquela época não tinha [gravador], então precisava da memória, o Monarco ai é... É o nosso guru, também porque ele era o mais novo deles.

Surica: É conforme Monarco fala: para vestir aquele fardão, você tem que ter um passado. E eu fui cria da escola, não é?

Aurea: Seu Monarco até quer fazer uma reunião para buscarmos as "músicas do baú", como ele fala:

- Vamos buscar, que a Velha Guarda tem um baú muito rico, vamos nos unir pra lembrar.

Já Noca da Portela destaca a velha guarda do samba como uma "profissão de guerreiros", que se sacrifica para levar adiante a história do samba, enaltecendo o grupo Velha Guarda da Portela e incluindo-se na tradição:

Noca: Eu aprendi muito, virei - modéstia à parte - um compositor consagrado, até porque eu prestava atenção, e aprendi realmente, com Chico Santana, Alberto Lonato, Manacéa, Monarco, Casquinha, e tantos outros da Velha Guarda, que me ensinaram bastante. Serei eternamente agradecido a eles. Eu mesmo não participo dos shows da Velha Guarda da Portela, mas é claro que estou entre os compositores que têm história na escola.

(...)

Eu, quando cheguei na Portela, tive que bater continência pra mais de vinte - hoje quem entra na escola não bate continência pro Noca, pro Monarco.

A tradição iniciada por Paulo da Portela e herdada pela Velha Guarda aparece mencionada principalmente na entrevista de Surica.

Surica: E não podemos, também, esquecer do nosso saudoso Paulo da Portela, que foi o fundador da Portela. Hoje em dia, essa disciplina que a Velha Guarda tem, isso tudo nós agradecemos ao nosso professor, Paulo Benjamin de Oliveira.

Serginho e Áurea Maria, provavelmente por terem crescido na condição de observadores-participantes da Velha Guarda, mencionam os nomes que para eles talvez fossem os mais próximos representantes da tradição:

Serginho: Lembro muito de um vizinho nosso, o Seu Alvaiade, que na Portela ele era como se fosse o substituto do Paulo da Portela.

Aurea: ...Lincoln foi um dos parceiros de Paulo da Portela, participava da velha guarda. Do início, da primeira formação, meus tios participavam, então a lembrança é bem presente.

Monarco, Serginho e Surica se preocupam em ressaltar que a Velha Guarda musical está contida na velha guarda da escola: 
Monarco: Porque a velha guarda do samba sempre existiu, os mais velhos já eram chamados pela gente de "velha guarda"(...). Mas o grupo musical não existia.

Serginho: ... a velha guarda, no geral, não é só a musical, são aqueles que trabalharam na escola, por isso são chamados de velha guarda. Vieram muito antes, trabalharam, foram diretores de harmonia, ou mestres-salas, ou da ala das baianas, esses todos antigos são chamados de velha guarda (...). Esses que são chamados de Velha Guarda musical, ou Velha Guarda show, além de trabalharem, (...) compunham sambas, digamos assim, aqueles sambas desinteressados, sem aquela forçação que tem hoje em dia, da gravação, era um samba para ser cantado, ali dentro, no dia a dia, numa brincadeira...

Surica: Porque velha guarda só existe uma, só que o Paulinho [da Viola] destacou a Velha Guarda show, com os compositores da Portela, mais antigos, então ele montou esse grupo. Mas a velha guarda é uma só, também um palco não comporta todo mundo.

Quanto à função da Velha Guarda e à sua especificidade, definem:

Monarco: ... a Velha Guarda é sentinela de tudo. É na Velha Guarda que você ainda ouve um samba que era cantado na comunidade, sem ser sucesso de rádio nem nada, mas uma coisa pura...

(...)

... a nossa Velha Guarda se preocupa em manter a nossa linha. Cantamos as coisas de nossos ancestrais. Coisas lindissimas que ficaram. E deixa quem quiser falar! (...) A rádio não quer tocar? A gente canta na esquina!

Serginho: Na Velha Guarda tem uma coisa, que é muito maior que a gente... Ali a gente não tem a vaidade de... Eu não tenho a vaidade de chegar ali, cantar sambas meus, mas tenho a responsabilidade de guardar os sambas daqueles antigos, que ficaram. Porque a nossa responsabilidade é mostrar a nossa cultura, aquilo ali é que eles mostraram antes, e aquilo ali não pode morrer.

Surica: A espinha dorsal de qualquer escola é a velha guarda, então, não pode excluir a velha guarda. E o relacionamento da velha guarda com a escola é igual até hoje. Nós somos independentes da escola, então nada nos atinge.

Aurea: Eu acredito que a Velha Guarda, na sua trajetória, passou e passa uma mensagem muito forte, cultiva a raiz do samba.

Outra particularidade apontada por Monarco a respeito da velha guarda é o amor à escola: alguém da velha guarda não muda de escola, como acontece com puxadores, mestresala e porta-bandeira. Também a geração antiga, que teve que defender a escola e lutar por ela, é destacada por Monarco e Surica.

Monarco: Aquela disciplina, todos bem vestidos. Na escola de samba, a Diretoria tem respeito por eles, que sabe que eles ali representam os que começaram tudo, não é? Os coroas da antiga aí, que muitos correram de polícia, e tudo, pra hoje a escola de samba estar aí. Portela é uma, 
Mangueira é outra, as outras não chegaram a pegar isso, pegaram já o filé mignon...

(...)

O samba sofreu muito. Hoje é o patrimônio cultural do nosso país, mas a gente sofreu horrores.

Surica: Sabe que o samba naquela época era muito discriminado, e eu fui uma delas, eu fui muito discriminada por sair em escola de samba. Hoje em dia todo mundo está dentro do samba, né?

(...)

O pessoal tinha mais amor ao samba, eles vestiam a camisa, hoje em dia não, todo mundo agora é sambista. Eu sei que não sou como todo mundo, eu sei, porque eu sou sambista, visto a camisa, mas agora não, todo mundo agora sai em escola de samba. Na época era bem discriminado. Agora todo mundo sai.

Serginho incorpora essa visão, falando da sua geração como tendo encontrado mais facilidade do que a anterior:

Serginho: Eu posso dizer que hoje em dia eu estou comendo o filé mignon, porque os outros ralaram lá atrás. Antigamente, quase não tinha nenhum show da Velha Guarda, era um show por ano, e eles ralaram pra criar aquele nome, para agora a gente estar com o filé. Mas alguém tinha que fazer isso, e nada mais justo do que a gente também, que foi criado ali dentro, eu, Áurea, Mauro Diniz... A gente acompanhou a nossa vida toda a Velha Guarda da Portela. Então eu acho que ninguém ia dar mais valor do que a gente ali, que viu, e que considera isso a nossa raiz.

$\mathrm{Na}$ Velha Guarda estariam os sambas "verdadeiros", que nascem do "ventre" da escola e que são os que ficam:

Monarco: Às vezes o rádio faz sucesso numa mentira, mas tem um prazo de validade, que de repente você procura - e quedê? E o nosso está aí.

Serginho: E é uma coisa natural, essa música [Esta melodia], a história dela, não foi feita para tocar no rádio, não foi feita para nada, mas é de uma energia tão grande... A gente, quando canta essa música lá, principalmente na Portelinha, (...) parece que todos os deuses da Portela estão ali naquele momento, todos os orixás, é de uma energia...

Monarco, Serginho e Noca abordam também a diferença entre culturas de dentro e de fora da escola, indicando que cada um tem a sua especificidade, devendo-se preservar o samba das influências externas:

Monarco: Mas saiu dali, do ventre da Portela. Não é pegar as coisas lá do rádio, que já são de outra cultura, e trazer pra dentro do nosso, que é onde a nossa cultura já é de raiz, ali, de nascença. Teve uma época em que andaram deturpando muita coisa, teve diretores lá chamando pessoas do rádio pra fazer samba na Portela. Eles não vão fazer igual ao sambista, o humilde ali. 
Serginho: A nossa cultura, ali dentro, ai vai cantar a cultura do outro? Nada contra o Rebolation, eles têm o espaço deles, até se eles forem lá, à Portela, para a gente também vai ser um orgulho, eles cantando a música deles. A gente ali dentro do nosso terreiro, a nossa cultura, a nossa raiz, a gente não vai cantar Rebolation.

Noca: Os caras estão indo pra um samba desses, fácil de ganhar dinheiro, esquecendo que a poesia é que tem que prevalecer. A poesia, a coisa mais bela do mundo é a poesia do samba de verdade, a poesia pura, sem mistura.

É importante notar, na narrativa de Tia Surica, que a segunda situação que destaca como mais gratificante, junto com ter cantado o samba de Paulinho da Viola em 1966, é a do desfile, mesmo nos dias atuais.

Surica: O que mais me dá satisfação é o dia de carnaval, o desfile. Quando eu vejo aquela minha águia entrando na Marquês de Sapucaí, eu esqueço tudo. Até hoje. Aquela águia pra mim é tudo, aquela águia altaneira. Infelizmente o samba mudou muito, mas mesmo com isso ai quero estar presente.

Isso serve para pensar que, ao contrário do que poderiam fazer supor as críticas gerais à situação atual das escolas de samba e do desfile, pelo menos para uma das pastoras da Velha Guarda da Portela o desfile ainda se liga ao sentido pleno de pertencimento à escola. Zé Katimba também menciona que continua apaixonado pela escola, porque não tem como se desvincular: "é como boca e batom, peixe e mar".

\section{Velha Guarda do Império Serrano}

As narrativas associadas ao Império Serrano mostram um tipo de articulação em torno do grupo que reflete características de uma identidade coletiva fortemente associada à idéia de resistência. Aliada à disciplina observada pelos fundadores do Império, está a preservação de uma raiz cultural muito ligada ao jongo e ao candomblé.

Uma letra de samba, de cuja autoria Zé Luiz do Império participa, complementa as narrativas que serão apresentadas em seguida:

Olha nosso povo ai

Conjugando no presente o verbo resistir

Nossos corpos densos resistindo à opressão

Nossos nervos tensos suportando a humilhação

O olho cresceu, tumbeiro chegou

O couro comeu, o pau roncou

Mas o negro é aroeira

Envergou, mas não quebrou 
Preto velho tem mandinga

De amansar feitor

Nega mina tem um dengo

De matar de amor

Palmares, balaios, malês, alfaiates

Fugas, guerrilhas, combates

Mão na cara, dedo em riste

Teatros, fundos de quintal, candomblés,

Blocos, jongos, afoxés

Assim também se resiste

Negritude resplandecente

Consciente a se reconstruir

O nosso nome é resistência

Olha o nosso povo aí

Nei Lopes, Sereno e Zé Luiz do Império, Nosso nome: resistência. [faixa 8 do $\mathrm{CD}$ anexo]

Apesar de não ser diretamente dirigido ao Império Serrano, nesse samba estão presentes idéias que se fizeram sentir em algumas das entrevistas:

Wilson: Ai é que eu digo: é uma covardia. Na hora que o negro lá do morro pode ser rei, ai você fala:

- Não, tu vai empurrar a minha alegoria, cara.

É assim. E quem construiu aquilo? Foi ele, e ele não tem direito a coisa nenhuma.

Ivan: Na minha época, o pessoal já acordava mais, porque a gente se ligava mais no assunto dos escravos, escutava as histórias do tempo em que roubavam samba, roubavam música...

Balbina: Quando era eleição a gente saía pro Getúlio, Eduardo Gomes nunca foi eleito. Ele era racista, de pobre e de negro. Negro não votava nele...

Zé Luiz: O Império continua mantendo essa religiosidade dele, um pouco distribuida entre umbanda, candomblé e um pouco do jongo, que não chega a ser uma religião, mas é um tipo de procedimento de quem vem mais do norte do Estado, aquela coisa mesmo de escravo, bem africana, realmente... E essa mistura deu no Império Serrano, então você sente na batida, no tipo de andamento, muita africanidade.

(...)

Aí a gente já vai cair num outro problema, do negro, de ser subserviente e achar que chegou um cara que sabe mais do que ele, então o cara é que é o bom, e ele, coitado, não sabe nada, então precisa ser obediente a ele, essas coisas.

O diagnóstico é semelhante ao apresentado antes: o samba mudou, se modernizou, mas com isso perdeu suas características originais. 
Wilson: Se perdeu aquele prazer, aquela honra de carregar a bandeira da sua escola. Culpado disso é quem paga, não é? Quem começou com isso de importar foi o Natal da Portela. Ele levou uns dois mestres-salas do Império, contratava, pagava, e isso foi crescendo, foi mudando e as escolas todas começaram a fazer a mesma coisa para poder concorrer. Então esse amor pela escola morreu, só existe na velha guarda, na bateria e alguns compositores.

Zé Luiz: Eu não acho que o que está aí melhorou em nada. Virou circo, aquilo ali para mim não quer dizer nada, se o cara sair de dentro de uma caixa... Aquilo não é samba, é outro espetáculo. Vale para ponto e é bonito, tem certas coisas que são, plasticamente. Hoje o que interessa é o tamanho do carro, a rainha de bateria, a melhor comissão de frente, isso são os quesitos mais respeitados. Sou contra, mas vou fazer o quê?

Ao mencionar a formação da Velha Guarda do Império Serrano, suas atribuições e missão, aparece também a diferenciação entre a velha guarda e sua representante musical:

Wilson: Velha Guarda é o seguinte: existe a velha guarda da escola e a Velha Guarda "show"... O que eles dizem que é Velha Guarda da Portela, com o Monarco, aquilo ali é a Velha Guarda show. Mas velha guarda mesmo é a que sai na avenida com setenta, oitenta coroas dançando, entendeu? Não é porque é velha guarda que é compositor, às vezes não toca nada, mas desfila na escola, entendeu? É o mesmo amor, mas no show são dez, no máximo doze pessoas. No Império também tem, gravou um disco bonito, tem um repertório muito bom.

(...)

A comissão de frente da escola de samba antigamente, na Portela até pouco tempo, quem é que vinha na frente? Era a velha guarda. Antes, escola de samba tinha o livro de ouro, que era a contribuição dos comerciantes do bairro, que ajudavam com aquela importância pra fazer o carnaval, eles eram a comissão de frente. Porque eles tiravam o chapéu e diziam pro povo: - Esse é o carnaval que nós pudemos fazer.

Essa era a finalidade da comissão de frente, não é isso que está aí. Por isso que eu digo a você: mudou tudo. (...). Hoje bota mulher grávida, bota mulher não sei aonde, o cara entra com uma caixa de som, é comissão de frente, mas não é autêntica. Você pode melhorar, mas não deturpar desse jeito.

Ivan: Então nós somos a Velha Guarda, mas representando o lado musical desses que foram os fundadores. Quer dizer, nós somos a parte, como se fosse, uma espécie de uma segunda geração da fundação do Império.

(...)

Velha Guarda show é diferente da velha guarda, eles acabam sendo a velha guarda para quem tá chegando também, sem dúvida.

(...)

...a velha guarda de uma escola de samba, de uma agremiação, não necessariamente tem que ser idoso, não. Até porque, você de repente começa com 10 anos, até ajuda na fundação de escola, mas com 40 anos você está jovem ainda e já é um cara da velha guarda, porque começou com 10 anos. É um exemplo, para a pessoa entender.

(...) 
É claro que a idade influi, sem a menor dúvida. Mas na realidade o que conta é o tempo que você tem na agremiação. Porque tem gente que começou tarde.

O critério é que tem que ter história na escola, por isso que eu falo: não basta ter 50, 60, 70 anos para ser Velha Guarda show.

Lindomar: ... as pessoas que estão fora dizem que Império é a única escola que tem três velhas guardas: velha guarda da escola, ala dos Cabelos Brancos e ala musical. Mas no fim é uma coisa só, é Império Serrano.

Balbina: Velha guarda é aquele que tem história, tem um histórico no meio, porque se não você não pode estar numa Velha Guarda show da escola. Que história você vai contar? Você quando nasce não tem um histórico? Não tem que ter?

Zé Luiz: Então elas se visitam - a velha guarda tradicional, que eu acho muito mais importante até do que a Velha Guarda musical. A Velha Guarda musical é importante pelo registro... Mas essa velha guarda, ela é muito mais forte, muito mais... Quer dizer, veste mais a camisa, você vê, os senhores e as senhoras fazem questão de estarem muito bem vestidos... É muito bonito.

Em quatro das cinco narrativas do Império Serrano, aparecem críticas ou questões que permitem pensar em percepções heterogêneas a respeito do grupo:

Wilson: A Velha Guarda é complicada, de vez em quando as pessoas não levam muito a sério. E dirigir Velha Guarda é um problema: velho é cheio de mania. Eu não quero dirigir; se tem show, eu vou, mas tomar conta é complicado. Velho é pior que garoto. Pergunta pro Monarco!

Lindomar: Quem me conhece há muitos anos sabe quem eu sou, mas não que eu viva dentro do Império. Mas fiquei na Velha Guarda, e sempre que tem reunião estou, nunca faltei, a não ser em caso de doença. Quando tem apresentação, show, ensaio, eu estou, não falto, não posso faltar...

(...)

Gosto de cantar, mas não penso em cantar sozinha. Só com a Velha Guarda, penso em cantar sempre junto com eles, e continuar com minha vida, porque eu estou com a carteira da Ordem dos Músicos, mas não sou uma artista. Eu faço parte de um grupo. E todo grupo tem que ter consciência de que aquilo ali é um elo. Aquela rodinha, fora do elo, não é nada.

Balbina: Então, uma velha guarda, até a comum, tem que saber se aquela pessoa desde moça estava na escola, é uma história. Vem gente estranha, que não tem nada a ver com a escola, nunca foi da escola e entra para a Velha Guarda. Isso não está certo!

(...)

Mocinhas, mulheres, na hora do ensaio, quando chovia, para poder ensaiar, ficavam com vassoura tirando água, para a gente poder ensaiar. São essas que lutam pela escola! Pessoas que chegam, sem mais nem menos, ainda querem chutar a pessoa antiga! Quer ser mais na escola que a pessoa antiga, não pode.

Zé Luiz: Já estava começando esse tipo de confronto que eu não queria. Porque algumas pessoas achavam que fazer parte da Velha Guarda já era 
um status que se dava a eles, e é, mas não passaram pela coisa como deveria ter sido historicamente:

- Ó, eu comecei daqui, fui, fui...

Comecei a ver, assim, não chegava a ser insubordinação, mas:

- Não, a gente sabe fazer...

Quer dizer, começou a se criar um desgaste normal, e eu, não querendo defender nem atacar ninguém, ficava na minha.

Uma última modalidade de comparação merece registro. A partir de uma provocação de Wilson das Neves, que mencionei na entrevista com Zé Luiz do Império, criou-se um diálogo direto entre duas entrevistas:

Wilson: Por que é que eles botam a velha guarda no fim da escola? Pra não verem as coisas erradas, senão eles iam reclamar.

Zé Luiz: ...existe ai uma controvérsia. Não é bem assim, não, porque a velha guarda vinha como comissão de frente da escola, como quem diz:

- Eu estou aqui apresentando o que eu fiz.

Vinham os veteranos da velha guarda. Isso era a função da velha guarda. Mas ai começou a valer ponto a comissão de frente. Mas se vem todo mundo sendo a mesma coisa, vai ter que dar 10 pra todo mundo, não é?

(...)

...então essa coisa da velha guarda ir lá pra trás foi legal, e bem representada, que hoje essa velha guarda tradicional vem em cima de carro, e eles gostam de brincar, então acho que tem esse lado também. Quer dizer, perdeu uma coisa, essa representatividade de ser o primeiro a ser mostrado, mas em compensação ganhou lá atrás, de brincar...

É claro que esse tipo de estímulo induz o tema, mas ao mesmo tempo a resposta não parece ter sido improvisada, indicando tratar-se de assunto que pode ter sido objeto de prévia reflexão. Considerando-se que houve uma fase posterior de validação e reformulações, mesmo provocado diretamente por mim esse trecho pareceu coerente com o restante da narrativa.

Encerrando estas análises, reflito sobre a riqueza das entrevistas e as infinitas possibilidades de diálogos entre elas. Chego à conclusão de que este trabalho de observação a partir das entrevistas só é possível quando os próprios colaboradores exercem um olhar "sociológico" ou distanciado sobre a realidade em torno de si. Aquilo que é naturalizado, não sendo enunciado com clareza, mais dificilmente será percebido no discurso. Ainda que a função do estudo das narrativas seja justamente exercitar a atenção para os diversos elementos, verbalizados ou não, presentes na construção de uma história de vida, parece haver uma relação direta entre as possibilidades de interpretação e a sensibilidade do colaborador. 


\section{Temas}

Seguem desenvolvidas abaixo três divisões temáticas que foi possível elaborar no decorrer da pesquisa, com base nos contatos com os colaboradores e nas narrativas resultantes das entrevistas. Assinalo desde já a pertinência de um aprofundamento das referências que possibilite dar-lhes maior sustentação.

\subsection{Velha Guarda e velha guarda}

Eric Hobsbawm inicia A Era das Revoluções (1977) afirmando: “As palavras são testemunhas que muitas vezes falam mais alto que os documentos" (p. 17). Para dar dimensão à profundidade da transformação que marcou o período entre 1789 e 1848, o historiador arrola termos como "classe média", "classe trabalhadora", "nacionalidade", "capitalismo" e "socialismo", que se vinculam a coisas e conceitos cuja ausência no mundo do século XX seria inimaginável.

O termo "velha guarda" não é exclusivamente usado no Brasil: vieille garde, old guard e vieja guardia são usados, por exemplo, nos países francófonos, anglófonos ou hispânicos, respectivamente, para designar desde um grupo conservador até os mais antigos integrantes de diversos segmentos sócio-econômicos. O termo parece ter sido cunhado no contexto do século XVIII, havendo pelo menos dois registros que vale mencionar: o primeiro é a existência, durante o Primeiro Império Francês (1804-1814), da Guarda Imperial, unidade que reunia os mais valorosos soldados do Exército de Napoleão Bonaparte e que se subdividia em Jovem Guarda, Guarda e Velha Guarda, esta última formada pelos primeiros veteranos das Guerras Napoleônicas ${ }^{36}$; o segundo vem do exército estadunidense, que estabelece o dia 3 de junho de 1784 como a origem da sua Old Guard, unidade militar criada como resultado do Tratado de Paris, que reconhecia a independência dos Estados Unidos ${ }^{37}$.

\footnotetext{
${ }^{36}$ Em Napoleão, Paul Johnson (2002) refere-se à Guarda como a força de elite do Exército e informa que os integrantes da Velha Guarda eram escolhidos por sua estatura e pela experiência mínima de cinco anos de serviços prestados. O autor narra o episódio da Batalha de Waterloo em que, ordenados a recuar - pela primeira vez -, dois batalhões da Velha Guarda francesa teriam sido arrasados pelos canhões inimigos por terem se recusado a aceitar a retirada (p. 185).

${ }^{37}$ A fixação do nome também estaria associada às disputas na Europa e a Primeira Infantaria, depois da paz selada entre EUA e Grã-Bretanha em 1815, se tornou Terceira Infantaria, a única com descendência direta da primeira formação do Exército. Disponível na página da Velha Guarda do Exército Norte-Americano: http://www.army.mil/info/organization/unitsandcommands/commandstructure/theoldguard/. Último acesso em 20 jan. 2011.
} 
O verbete "vieux" ou "vieil" do dicionário Le Robert pour tous (1994) registra a expressão "un vieux de la vieille [um "velho da velha"]: de la vieille garde, un vieux soldat (sous le Premier Empire); un vieux travailleur", aludindo a um velho soldado que pertenceu à Velha Guarda do Primeiro Império ou a um velho trabalhador. Já no Merriam-Webster's Collegiate Dictionary (1996) há dois significados para "old guard". "1: a group of established prestige and influence [grupo de prestígio e influência reconhecidos] 2: the conservative members of an organization (as a political party) [os integrantes conservadores de uma organização (como um partido político)]". Guardia Vieja é como se chama o primeiro período de gestação e desenvolvimento do tango como gênero central para a identidade nacional da Argentina; e em outros países da América Latina são freqüentes as referências a velhas guardas como grupos de "veteranos" de profissionais.

A origem do termo no Brasil parece também aproximar-se do período histórico em que surgiram as unidades de veteranos franceses e norte-americanos. A Guarda Nacional foi criada em agosto de 1831, adotando-se o modelo da Revolução Francesa ${ }^{38}$. José Ramos Tinhorão (2005) afirma que o Jardim da Guarda Velha, no Rio de Janeiro, existia desde 1882, tendo sido assim chamado por sua localização, próxima do antigo posto de guarda do Largo da Carioca. Lá se instalou também a Fábrica de Cerveja Guarda Velha, que custeava aos domingos música de banda para seus freqüentadores. "Nada mais natural, pois" - escreve Tinhorão - "que logo se tornasse necessário construir algum palanque ou pequeno palco para a apresentação de artistas populares, não sem alguma ressonância de escândalo (mas também de muita curiosidade) por parte das famílias cariocas (...)” (p. 162). O Maxixe da Guarda Velha, que em 1899 integrava o primeiro ato da revista Gravoche, mostrava a importância do jardim. Tinhorão reproduz os versos de Artur Azevedo para música de Nicolino Milano:

\footnotetext{
"Eu não sou d'espalhafato,

Eu não sou d'imposturia,

Não me falta freguesia,

E o meu chope é o mais barato

Se vocês me olham d'esguelha,

Esse olhar não me acovarda:

No Jardim da Guarda Velha

Tenho a minha Velha Guarda.

Toda a noite em quantidade,

Se acham lá velhos e moços,

Que vão abrindo à vontade

Com punhados de tremoços.
}

\footnotetext{
${ }^{38}$ Cf. Carlos Guilherme Mota. História do Brasil: uma interpretação. São Paulo, Editora Senac São Paulo, 2008.
} 


\author{
E quando o freguês se entope \\ Tais tremoços a engolir \\ Pede sempre mais um chope \\ Para se desentupir" (pp. 163-164).
}

Pode-se imaginar, a partir dessa referência a um lugar de convivência popular trazendo o nome de Guarda Velha, uma dentre muitas possíveis fontes para a adoção do termo "velha guarda". Dando mais alguns passos no caminho de volta ao tema da Velha Guarda musical nas escolas de samba, temos em 1947:

Aquele que disse que não gosta dos nossos ritmos é porque na verdade nunca ouviu nossos ritmos. Não sabe a gostosura que vem da junção da pancadaria dos pandeiros, dos ganzás, dos tamborins, dos recorecos, das cuícas, dos surdos, dos omelês, dos pratos, dos surdos, dos chocalhos, etc. Temos visto muita gente que diz detestar o som bárbaro desses instrumentos de percussão acompanhar horas e horas pelas ruas no carnaval os grupos ou escolas de samba quando desfilam com o seu material completo tangido por mão de legítimos virtuoses. Foi para provar a riqueza dos nossos ritmos, e a possibilidade de certos instrumentos de percussão que Pixinguinha compôs para orquestra a peça que ele denominou "Concerto para Bateria". Depois que foi executada a primeira vez, essa composição tem sido insistentemente pedida pelos ouvintes. Como se trata de um curto completo de ritmos brasileiros, ela vai servir para encerrar a audição de hoje do Pessoal da Velha Guarda (transcrição de locução de Almirante em $O$ Pessoal da Velha Guarda, Programa No. 1, que foi ao ar em 8 de outubro de $1947^{39}$ ).

Como bem observa Marcos Napolitano, "as locuções de abertura de quase todos os 20 programas da série veiculam alguma crítica à cena musical dos anos 1940 e início dos anos 1950, para elogiar a grandeza da música popular do passado, leia-se aquela feita até o final dos anos 1930" (2007, p. 61). Almirante teria desempenhado um papel importante não só na cristalização do termo "velha guarda" aplicado à música popular brasileira, como também na consolidação do "panteão de compositores-heróis [como Noel Rosa, Ismael Silva, Cartola e Pixinguinha] que os anos 1960 consagrariam de uma vez por todas, incorporando-os à tradição da MPB culta" (p. 62).

Partindo de todas essas caracterizações de velha guarda, volto àquela que me foi apresentada pelos colaboradores desta pesquisa: de designação geral, atribuída aos fundadores das escolas de samba - como a qualquer outra categoria de "veteranos" -, que saíam na "linha

\footnotetext{
${ }^{39}$ Os textos transcritos de todos os programas, veiculados pela Rádio Tupi entre outubro de 1947 e maio de 1952, estão disponíveis em http://daniellathompson.com. Último acesso em 23 jan. 2011.
} 
de frente" 40 da escola nos primeiros carnavais, velha guarda passou a ser a ala, como é até hoje, em que se reúnem os "antigos" da escola (ver a letra de Dicró na apresentação desta dissertação para algumas dentre as várias atribuições que um "velha guarda" pode ter). A partir dos anos 1960 teriam começado a se constituir as Velhas Guardas musicais ${ }^{41}$, reunindo, dentre os participantes da velha guarda, os compositores, músicos e cantores que levariam aos palcos a "história viva" da escola.

Seguindo a linha das palavras como sinais de constituição histórica sugerida pela citação a Hobsbawm, deve-se apontar para alguns aspectos do vocabulário da escola de samba, ainda que de maneira pontual. Além de congregar pessoas com "títulos" familiares incorporados ao nome - Tia Surica, Tio Hélio, Mano Décio da Viola, Carlinhos Vovô, Vovó Maria Joana, Mano Elói Antero Dias, para citar alguns - e da adoção de figuras da realeza em sua organização, é comum a referência à disputa entre escolas na avenida como uma batalha: a escola defende o seu enredo. Nesse contexto, a velha guarda como sentinela aparece como que resgatando o sentido original de velha guarda, de unidade que reúne os mais "valorosos guerreiros", que irão zelar pela preservação da tradição que lhes dá sustentação.

A referência à velha guarda e à Velha Guarda (musical) foi citada por nove dos onze colaboradores, embora com pequenas variações quanto a serem os grupos musicais considerados independentes da escola ou não, ou separados da velha guarda "geral" ou não. Como dizem Lindomar, Zé Luiz, Monarco e Serginho Procópio, trata-se de um "elo", que perde o sentido sem a consciência dessa dimensão; de um nome que está acima de qualquer um; de um grupo que tem a missão de manter acesa a chama, levar adiante o nome dos antigos. Há uma dimensão interessante no que se refere à relação entre indivíduo e coletividade: integrar uma Velha Guarda musical pode dar a impressão de anulação dos indivíduos em prol da fixação do nome da escola, mas o trabalho na Velha Guarda pode servir como impulso ou estabelecimento de uma carreira e um reconhecimento individual.

Em suma, "velha guarda" ganhou acepção específica graças ao samba. Literalmente: a locução é definida pelo Houaiss como "1. os mais antigos em determinado grupo de pessoas;

\footnotetext{
${ }^{40}$ Ver esquema de desfile dos anos 1930 desenhado de acordo com relato de Ernani Rosário, em Silva \& Santos, 1979 , p. 52.

${ }^{41}$ De acordo com os verbetes dedicados a velhas guardas no Dicionário Cravo Albin, a constituição formal das Velhas Guardas musicais seguiria a seguinte ordem: Portela (1970), Mangueira, Salgueiro e Império Serrano (década de 1980) e Vila Isabel (anos 1990). Há, em outras páginas da internet, referências a uma formação da Velha Guarda da Mangueira em 1956 que não pude confirmar em bibliografia (no estudo sobre a escola feito por Maria Julia Goldwasser em 1975, por exemplo, não há informações que ajudem a esclarecer isso). Levando em conta o lançamento de discos com o nome Velha Guarda, a ordem seria: Portela (1970), Mangueira (1989), Salgueiro (2003), Vila Isabel (2005) e Império Serrano (2006). Esse critério, embora impreciso em termos de indicação efetiva sobre a primeira organização dos grupos, ao menos lhes traz alguma "concretude".
} 
1.1. Regionalismo: Brasil. o conjunto dos componentes mais antigos e importantes de uma escola de samba. 2. a geração de mais idade". A diferença é que, na vida, a locução é freqüentemente substantivada: Monarco lembra, por exemplo, que "um velha guarda" não muda de escola, reforçando mais uma vez a dimensão principal do pertencimento ao grupo antes de qualquer definição individual. Melhor dizendo: a personalidade individual é importante na medida em que o indivíduo deve demonstrar trazer introjetadas as regras de conduta, as habilidades e os valores que norteiam o grupo, mas sendo um desses valores a disposição em carregar o nome do grupo à frente do seu próprio. 


\subsection{Mediações e jornalismo cultural}

Uma das questões provocadas pelo contato com os colaboradores desta pesquisa, a respeito da qual pude refletir brevemente, foi a relação entre jornalismo cultural e samba. Penso haver três movimentos interligados nessa relação: a forma como se caracterizou a produção historiográfica sobre a música popular urbana no Brasil, no começo do século XX (a importância do registro jornalístico); o trânsito do jornalista entre mundos sócio-culturais diversos (a mediação); e o poder de nomear, que se vincula à questão do reconhecimento, da valorização de um assunto ou personagem quando divulgado.

Registro, mediação e valorização são três aspectos que marcam a atuação do jornalista em geral, mas que têm uma especificidade quando se trata de jornalismo cultural e - o que me interessou mais diretamente - quando se trata do jornalismo cultural vinculado à música popular. Essas três dimensões podem ser entendidas como formadoras do "tipo" jornalístico de atuação, que estava presente no imaginário dos colaboradores - ou no meu próprio - em situações vividas ao longo da pesquisa.

O jornalista como registrador de fatos aparece na própria configuração da música popular urbana como objeto de estudo e campo de investigação, já mencionada, mas que vale pormenorizar. José Geraldo Vinci de Moraes identifica, no artigo "História e historiadores da música popular no Brasil”, uma primeira geração (em sentido amplo) de historiadores (também em sentido amplo). Almirante, Vagalume, Jota Efegê, Lúcio Rangel, Orestes Barbosa, Mariza Lira, Edigar de Alencar, entre outros, foram responsáveis pela constituição de coleções que se tornariam importantes acervos de registros da música popular urbana e registraram seus "primeiros tempos", na primeira metade do século XX.

Fosse com aspirações "científicas" ou em forma memorialística, esse grupo de pesquisadores - e praticamente apenas esse grupo - deu início à historiografia da música popular urbana, que era marginalizada pela elite intelectual e pelas instituições de ensino e pesquisa do país. O fato de serem todos atuantes não na academia, mas nos meios de comunicação - jornal, rádio e revistas - indica como se constituiu um lugar social alternativo ao normalmente autorizado a produzir conhecimento; assim também, o fato de eles estarem presentes nas situações e universos que descrevem (rodas de samba e outros cenários da boêmia carioca) forja credibilidade e autoridade, ainda que numa prática empírica e amadora. Eles constituíram, enfim, uma narrativa própria, organizando um autêntico discurso historiográfico sobre a música popular. Moraes desenvolve seu artigo adotando a operação 
historiográfica de Michel de Certeau, fundada nas relações entre um lugar social, uma prática e o texto. Observa que as obras desses cronistas ainda hoje são tratadas como fontes primárias e fidedignas, dando autoridade a investigações mais recentes.

Apesar de os estudos sobre a história da música popular não terem sido iniciados por historiadores de ofício, podem ser percebidas nos primeiros tempos desses estudos as influências do paradigma historiográfico tradicional - de costurar uma história feita de grandes nomes, dando uma sensação de progressão linear - em oposição à visão mais alinhada com a Nova História, buscando perceber as condições sociais em que essa tradição se inventa e se estabelece ${ }^{42}$.

O conceito de mediação proposto por Gilberto Velho ajuda a entender o segundo aspecto da atuação do jornalista cultural. Diz ele que o papel de mediador cultural é “desempenhado por indivíduos que são intérpretes e transitam entre diferentes segmentos e domínios sociais" (1994, p. 81), não sendo desenraizados ou marginais, mas que desenvolvem a capacidade de lidar com mais de um código, disso dependendo seu sucesso profissional e pessoal. Maria Laura Viveiros de Castro Cavalcanti (2008 [1994]) analisou, por exemplo, os carnavalescos como mediadores entre o mundo tradicional das escolas de samba e outros segmentos e domínios.

Hermano Vianna, ao elaborar suas indagações sobre $O$ mistério do samba, identifica a existência de "agentes mediadores" entre grupos sociais, e também de espaços onde se dava a interação entre esses grupos. Ele observa como a "naturalidade" do encontro entre músicos populares e intelectuais é construída (como acontece com os "mitos fundadores"). O mistério do samba estaria, assim, relacionado ao mistério da definição do que era ser "brasileiro" e da valorização da mestiçagem. A transformação do samba em música nacional teria sido, então, o "coroamento de uma tradição secular de contatos (...) entre vários grupos sociais na tentativa de inventar a identidade e a cultura popular brasileiras" (1995, p.34).

O caráter divulgador da atividade jornalística está dado pela própria natureza de seu ofício, mas seu sucesso como mediador depende de uma série de atitudes pessoais. Os jornalistas culturais não necessariamente são mediadores de acordo com a formulação de Gilberto Velho, principalmente porque muitas vezes não se estabelece um trânsito de mão dupla: o jornalista pode relatar aquilo que está no mundo do samba para um público difuso de

\footnotetext{
42 O curso ministrado pelo Professor José Geraldo foi particularmente importante para acompanhar os movimentos marcantes a cada período do século XX e observar as influências dessas duas correntes historiográficas em funcionamento.
} 
leitores, sem necessariamente participar do cotidiano desse mundo. O que parece curioso é que o seu sucesso como mediador está intrinsecamente ligado à sua atitude pessoal.

O terceiro eixo que caracteriza a atuação do jornalista em relação ao samba, o da valorização, relaciona-se com o fato de estar implicada a todo momento, no ato de selecionar, a necessidade de valorar o objeto a ser noticiado. Isso leva aos binômios "bom" e "mau", em geral fortemente associados aos critérios "verdadeiro" e "falso", ou "autêntico" e "ilegítimo". Essa terceira abordagem é a marca mais definidora da atividade jornalística, decorrendo, entre outras coisas, da característica do jornalismo de precisar apresentar novidades sempre e rápido, criando a necessidade de constantes descobertas. Também se relaciona com o destaque que se dá ao que se noticia, que empresta notoriedade ao assunto.

Há uma prática comum tanto àqueles jornalistas que foram os "primeiros historiadores" da música popular urbana do século XX quanto ao jornalismo cultural dos dias atuais, em que se atribui um valor àquele que "descobre" um artista. O jornalista cultural se confunde com o artista que retrata, como se compartilhasse do seu talento por ser capaz de distingui-lo, mas também o artista entra no jogo, ao “eleger" o jornalista. É como se o poder de um fosse transferido para o outro, e vice-versa, já que um ajuda o outro a nomear a si mesmo.

Uma passagem específica que vivi na gravação da primeira entrevista produzida para este projeto ilustra essa questão. No fim da entrevista, Zé Katimba (ver transcriação adiante) oferece uma música inédita, em primeira mão, para mim. Essa atitude corresponde ao jogo: é como se ele estivesse me dando um presente, um poder. Eu, como jornalista, estaria em posição de vantagem em relação a colegas, com o poder de me colocar como "descobridora", ouvinte privilegiada ou mesmo participante do valor atribuído à música dele. 


\subsection{Velho e novo}

"Quando a memória amadurece e se extravasa lúcida, é através de um corpo alquebrado: dedos trêmulos, espinha torta, coração acelerado, dentes falhos, urina solta, a cegueira, a ânsia, a surdez, as cicatrizes, a íris apagada, as lágrimas incoercíveis” (BOSI, 1994, p. 39). Com essa imagem, que aparece na introdução de Memória e sociedade: lembranças de velhos, Ecléa Bosi mostra as limitações físicas muitas vezes encontradas pelos narradores com os quais conviveu.

Munida de conceituações que vão da fenomenologia da lembrança de Henri Bergson ao convencionalismo adotado por Frederic Charles Bartlett a partir de W. H. R. Rivers, passando pela função social da atividade mnêmica observada por Maurice Halbwachs, a autora delineia o contexto histórico e social que encerra a velhice daqueles a quem ouviu, em seguida apresentando as lembranças desses narradores, em forma de histórias de vida para, por fim, tentar visualizar a substância social da memória.

Considero que será útil pormenorizar algumas das idéias desenvolvidas pela autora, que servem de referência para esta dissertação em dois sentidos: na maneira de produzir as narrativas e na caracterização que faz da velhice na sociedade industrial. Parece-me, no entanto, que a caracterização do papel dos velhos feita nesse contexto não se aplica inteiramente aos colaboradores das Velhas Guardas, como se verá ao final.

A autora começa por informar que não houve preocupação em confrontar as histórias narradas com outras versões, nem com relação a erros e lapsos, já que o interesse estava naquilo que foi escolhido por cada narrador para ser perpetuado em sua história de vida, que chama de "memória-trabalho". Ao tratar das análises sobre a memória por Bergson e Halbwachs, chama atenção para a impossibilidade de reviver o passado tal e qual, “impossibilidade que todo sujeito que lembra tem em comum com o historiador (...). Posto o limite fatal que o tempo impõe ao historiador, não lhe resta senão reconstruir, no que lhe for possível, a fisionomia dos acontecimentos” (p. 59, grifo da autora). Aponta para a confusão entre a lembrança da infância e aquilo que se "ouviu dizer" como indicação do caráter grupal ou social da memória.

Em seguida aplica essa "hipótese psicossocial da memória" ao estudo de pessoas idosas, perguntando se seria ela uma evocação pura do passado ou um trabalho de refação. Utilizando-se da comparação, feita por Halbwachs, do adulto com o velho, observa que, para o adulto ativo, a memória se distingue da vida prática como lazer ou contemplação, enquanto 
o velho "está se ocupandoconsciente e atentamente do próprio passado, da substância mesma da vida" (p. 60). Assim, ao chegar ao momento da velhice social, resta ao idoso a função de lembrar. A autora afirma que, na sociedade em que vivemos, o homem ativo se ocuparia menos de lembrar, enquanto o menos envolvido em afazeres cotidianos se dedicaria mais à refação de seu passado.

Passando a considerar idéias desenvolvidas por Bartlett, Bosi associa o que se lembra a como se lembra, levando em conta que, no momento de recordar, a relevância tanto existencial como social do fato exerceria influência.

A elaboração grupal comum seria, portanto, decisiva. Sem ela, tende a reproduzir-se com mais força o teor da 'primeira impressão', matéria daquela lembrança-imagem e da 'memória pura' de Bergson. Com ela, ao contrário, a primeira impressão ficaria cancelada e substituída pelas representações e idéias dominantes inculcadas no sujeito (hipótese de Halbwachs), ou apenas amortecida no inconsciente, de onde poderia sair durante o sonho e nos raros momentos de livre evocação (hipótese de Bergson) (p. 67).

Por fim, traz para a análise as observações de William Stern, que adota um modelo metodológico combinando a psicologia tradicional com a objetiva, conciliando as suposições da memória "pura" do inconsciente com a refação seguindo os valores do presente. A conclusão disso tudo é que, para bem avaliar a forma predominante de memória de um indivíduo, ele próprio deve fazer sua autobiografia. "A narração da própria vida é o testemunho mais eloqüente dos modos que a pessoa tem de lembrar. É a sua memória" (p. 68, grifo da autora).

Além dessa importante contribuição sobre por que escrever narrativas e memórias, a autora se dedica a entender o espaço da velhice na sociedade industrial, na qual os defeitos não são tolerados, nem tampouco os erros dos velhos. Com sensibilidade, percebe, no tom protetor com que as pessoas se dirigem aos velhos, estranheza e recusa.

Passando a falar, então, sobre a velhice como categoria social, Ecléa Bosi adverte: “A sociedade industrial é maléfica para a saúde" (p. 77). A partir desse ponto, observa como o velho é rejeitado: "A moral oficial prega o respeito ao velho mas quer convencê-lo a ceder seu lugar aos jovens, afastá-lo delicada mas firmemente dos postos de direção. (...) Quando se vive o primado da mercadoria sobre o homem, a idade engendra desvalorização” (p. 78).

Essa parece ser a marca mais determinante das relações na sociedade capitalista: a necessidade de uma produção constante de mercadorias, que se associa à valorização do novo, daquilo que pode ser usado ou consumido. Bosi então aponta para a possibilidade de reverter essa desvalorização: 
Durante a velhice deveríamos estar ainda engajados em causas que nos transcendem, que não envelhecem, e que dão significado a nossos gestos cotidianos. Talvez seja esse um remédio contra os danos do tempo. (...) A degradação senil começa prematuramente com a degradação da pessoa que trabalha. Esta sociedade pragmática não desvaloriza somente o operário, mas todo trabalhador (p. 80).

Ao perguntar o que seria necessário a uma determinada sociedade para que o homem, na velhice, permanecesse um homem, cita a resposta de Simone de Beauvoir: 'Seria preciso que ele sempre tivesse sido tratado como homem' e acrescenta: “o velho não tem armas. Nós é que temos que lutar por ele" (p. 81).

Fornecendo mais uma indicação sobre o interesse de que se origina sua pesquisa, declara que o ancião desempenha, ao rememorar, a função religiosa de unir o começo ao fim. "Um mundo social que possui uma riqueza e uma diversidade que não conhecemos pode chegar-nos pela memória dos velhos" (p. 82). A conversa evocativa de um velho se assemelharia a uma obra de arte, desalienadora para quem sabe ouvi-la, "pois contrasta a riqueza e a potencialidade do homem criador com a mísera figura do consumidor atual” ( $\mathrm{p}$. 83). Ao indagar o que teria levado ao declínio da arte de contar histórias, cujo veio épico é oral (não se confinando aos livros), pondera que talvez se deva à desvalorização da arte de trocar experiências. A sabedoria teria sido substituída pela opinião: “A informação pretende ser diferente das narrações dos antigos: atribui-se foros de verdade quando é tão inverificável quanto a lenda. Ela não toca no maravilhoso, se quer plausível. A arte de narrar vai decaindo com o triunfo da informação" (p. 86).

A narrativa aparece, assim, como uma forma artesanal de comunicação: "Hoje, a função da memória é o conhecimento do passado que se organiza, ordena o tempo, localiza cronologicamente. $\mathrm{Na}$ aurora da civilização grega ela era vidência e êxtase. $\mathrm{O}$ passado revelado desse modo não é o antecedente do presente, é a sua fonte” (p. 89). A arte de narrar seria, ademais, uma relação "alma, olho e mão", pela qual o narrador transformaria sua matéria, a vida humana.

O narrador é um mestre do ofício que conhece seu mister: ele tem o dom do conselho. A ele foi dado abranger uma vida inteira.

Seu talento de narrar lhe vem da própria experiência; sua lição, ele extraiu da própria dor; sua dignidade é a de contá-la até o fim, sem medo.

Uma atmosfera sagrada circunda o narrador. (p. 91)

Não sendo possível abarcar nesta breve síntese do livro de Ecléa Bosi as histórias de vida por ela produzidas - construídas com delicadeza e complementadas pela reprodução de documentos, fotografias e pela anotação de frases melódicas de pregões citados por um dos 
narradores -, procurarei apontar, na sofisticada análise elaborada ao final, elementos que vejo como especialmente importantes para a minha pesquisa.

A autora desenvolve, a partir das narrativas que ajudou a produzir, uma tipologia da memória, observando os espaços e objetos envolvidos nas narrativas, atentando para a memória política e a do trabalho. Com relação à lembrança individual, em sua relação com a memória coletiva, indica: "Somos, de nossas recordações, apenas uma testemunha, que às vezes não crê em seus próprios olhos e faz apelo constante ao outro para que confirme a nossa visão: "Aí está alguém que não me deixa mentir"' (p. 407). Com isso, voltando a citar Halbwachs, menciona que para o sociólogo francês cada memória individual é um ponto de vista sobre a memória coletiva, sendo essa memória marcada pelo movimento e a multiplicidade de "fios". Mais adiante, destaca: "O grupo é o suporte da memória se nos identificamos com ele e fazemos nosso seu passado. (...) As lembranças grupais se apóiam umas nas outras formando um sistema que subsiste enquanto puder sobreviver a memória grupal" (p. 414).

Uma apreensão do tempo dependente da ação passada e da presente, diversa para cada pessoa, seria o que formaria a substância da memória. "À resistência muda das coisas, à teimosia das pedras, une-se a rebeldia da memória que as repõe em seu lugar antigo" (p. 452).

A chave que leva de volta à pesquisa sobre a Velha Guarda está na página final de Memória e sociedade, na aproximação entre memória e conselho: "memini e moneo, 'eu me lembro' e 'eu advirto', são verbos parentes próximos” (p. 481). A memória do trabalho seria, enfim, o sentido e a justificação de toda uma biografia, que Bosi ilustra com o oferecimento, por um dos narradores, do conselho de tolerância para com os mais velhos, sintetizado na frase: 'Eles também trabalharam' (p. 481).

Essa frase lembra bem a definição de velha guarda exposta no começo deste capítulo, já que permite pensar o valor da velha guarda como o reconhecimento de que se trata de pessoas que "também trabalharam". A idéia de conselho acima pode ser aplicada aqui por supor a existência de uma figura que detém uma espécie de moral ou sabedoria, que a coloca em posição de ensinar àqueles que ainda não possuem conhecimentos ou experiências suficientes para discernir a melhor maneira de agir em determinadas situações. Esse papel pode ser identificado com as Velhas Guardas da Portela e do Império Serrano: ao se posicionar como legítimos continuadores da tradição inventada pelos fundadores das escolas, esses grupos estariam lutando por suas memórias e procurando transmitir, tanto pelos sambas quanto pelos "procedimentos", os valores do grupo. 
Nas tribos primitivas, os velhos são os guardiães das tradições, não só porque eles as receberam mais cedo que os outros mas também porque só eles dispõem do lazer necessário para fixar seus pormenores ao longo de conversações com os outros velhos, e para ensiná-los aos jovens a partir da iniciação (HALBWACHS ${ }^{43}$ apud BOSI, p. 63).

Assim, as Velhas Guardas ocupariam, mesmo na sociedade industrial que despreza ou anula o velho, um lugar central, pela via da manutenção da originalidade que teria feito das escolas de samba, escolas de samba. A decorrência física disso é que, diferentemente das restrições e fraquezas identificadas por Ecléa Bosi ao descrever seus narradores, no caso dos colaboradores desta pesquisa - ainda que se trate de pessoas idosas e que já tiveram problemas de saúde -, a atitude e a performance em nada se parecem com as de pessoas fracas ou envoltas em solidão:

Lindomar: É bom, porque é uma idade em que as pessoas pensam que a pessoa está no final e realmente não está. A pessoa está continuando, vivendo, é como agora, que eu escutei falar que é a melhor idade, e realmente. É uma idade que não tem compromisso de casa, de marido, tudo aquilo. É um compromisso com ela mesma, com o samba, e não é só mulher, tem homem e mulher.

Noca da Portela: Eu costumo dizer, estou com 77 anos, puxa, mas bem de saúde. Se o samba alimenta o meu corpo e a minha alma, eu sou um cara saudável. Dificilmente eu vou ao médico, quando eu vou lá, ele diz assim:

- Tá fazendo o quê aqui, rapaz? Abre vaga pra outro, você tá ótimo!

Eu digo:

- Doutor, você não tá me enganando não?

- Não, que nada, rapaz, você tá beleza pura, vai embora!

Então isso é uma felicidade, a saúde é uma coisa preciosissima do ser humano. Não adianta você ser milionário, riquíssimo, coisa e tal, e faltar o principal, que é a saúde.

Zé Katimba: Quando fico um pouco triste, vou fazer um samba. Começo a cantarolar e aí a tristeza vai embora, às vezes até aparece um amor. Não sei se eu suportaria as coisas todas que suportei - doença, câncer, disritmia, diabete - se eu trabalhasse em outro ramo.

Nesse contexto, o respeito aos mais velhos, em que pese a falta de convivência que se observa estar na raiz das críticas à descontinuidade da tradição, aparece também com força de dívida, mais do que de conselho.

\footnotetext{
${ }^{43}$ Halbwachs, Maurice. Les cadres sociaux de la mémoire. Paris, Félix Alcan, 1925.
} 


\section{PARTE II}

Nas próximas páginas são apresentadas as transcriações, na íntegra, acompanhadas de fotografias e mapas indicando os lugares principais onde cada colaborador residiu.

A ordenação das entrevistas se deu em três níveis: pela lógica do pertencimento aos grupos; pelo critério do gênero, que norteou a formação das redes; e pelo tempo de participação nos grupos (os mais "antigos" primeiro). Assim, estão dispostos os integrantes da Velha Guarda da Portela (homem mais antigo, homem mais novo, mulher mais antiga, mulher mais nova), em seguida Velha Guarda do Império Serrano (com a mesma lógica para a sua ordenação "interna", por assim dizer). Em seguida às oito entrevistas com integrantes dos grupos, foram incluídas as com sambistas que estavam, no momento da entrevista, "fora" desses grupos, embora relacionados a eles de alguma forma.

Os mapas foram feitos usando a ferramenta Google Maps, estando as localizações apontadas de maneira aproximada, para ilustrar os lugares onde cada colaborador residiu. Trata-se de um complemento visual à história de vida de cada um, que não deve ser confundido com os lugares nos quais se estabeleceram as principais relações pessoais. Isso poderia ser objeto de uma segunda abordagem, futura, que permitirá mapear os lugares considerados fundamentais para a socialização e a formação ${ }^{44}$ dos colaboradores. Caso o critério fosse o da vivência, muito provavelmente a região em torno de Madureira apareceria com destaque para todos.

As fotografias foram produzidas com a intenção de complementar a apresentação dos colaboradores. Monarco, Tia Surica, Áurea Maria, Ivan Milanez e Lindomar aparecem "em ação", representando as Velhas Guardas às quais pertencem; Serginho Procópio aparece também “em ação", mas no espaço "alternativo" da roda de samba ${ }^{45}$; Wilson das Neves está em sua residência, no quarto onde se concentram fotos e reportagens pela parede e em cima das mesas (há fotos suas e também de sua família, sendo uma que o mostra ao lado de sua mãe como baiana do Império Serrano das que mais chama atenção); Balbina, que já falecera quando voltei para validar a transcriação, aparece "em ação" pela sua escola em 1975, transmitindo o mesmo vigor com que a encontrei no dia da entrevista, em julho de 2010; Zé Luiz, que não fotografei porque ambos ficamos desconfortáveis com a idéia de uma foto "posada", é mostrado em foto do acervo da família de Balbina, caracterizado como integrante

\footnotetext{
${ }^{44}$ Ivan Milanez, por exemplo, ao informar seus endereços, frisava a todo instante que, onde quer que estivesse, sua "fortaleza sentimental" era sempre a Serrinha (informação verbal, em 08 jan. 2011).

45 Vale notar que o convidado especial naquela noite foi Monarco, o que mostra a Velha Guarda sendo incorporada nesse outro espaço, em que não se apresenta com exclusividade, mas como referência da "ascendência", da "raiz".
} 
da Velha Guarda do Império Serrano; Noca da Portela está em frente à sua residência recémpintada com as cores da escola; e Zé Katimba aparece como figura "independente" da Imperatriz Leopoldinense, sem referências imagéticas à escola - o que revela o próprio motivo de sua escolha como "ponto zero" - numa das muitas mesas em torno das quais nos sentamos para conversar desde agosto de 2008. 
Monarco durante apresentação da Velha Guarda da Portela no Portelão. Acervo pessoal da autora, dez. 2010

\section{MONARCO}

"O meu samba não tem agrotóxico, é um samba tirado do coração"

Lugares de Monarco:

1. Cavalcante

2. Nova Iguaçu

3. Oswaldo Cruz

4. Jacarezinho

5. Riachuelo
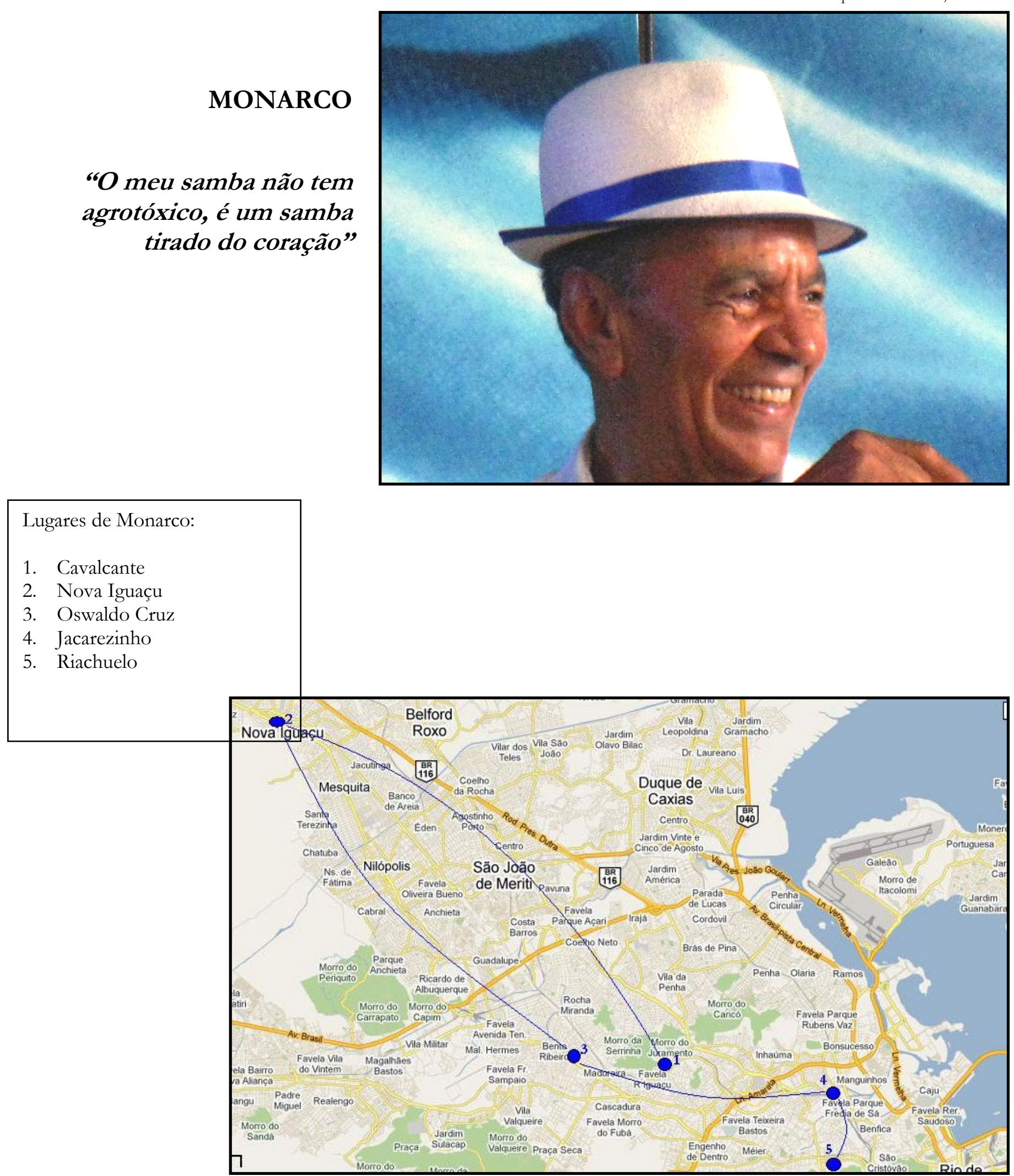
Meu nome é Hildemar Diniz. O apelido de Monarco veio da minha infância, quando eu tinha uns 5 ou 6 anos, mas era Monaco, sem o " $r$ ". Foi um dia em Nova Iguaçu, um camarada lendo um gibi de super-herói, que tinha uns negócios... Não sei o quê do monaco, aí eu achei gozado e comecei a rir. Aí ele:

- Tá rindo por que, seu monaco?

Aquilo bateu, ficou. Todo mundo vinha, os garotos batiam nas minhas costas: "Monaco!", pegou. Meu irmão me chamava de Naco, mas depois, em Oswaldo Cruz, entrou o " $r$ " e me tornei Monarco.

Nasci em Cavalcante, fui para Nova Iguaçu bem menino e fiquei lá até os 12 anos de idade. Depois vim morar em Oswaldo Cruz. Em Nova Iguaçu eu já fazia umas brincadeirinhas, umas paródiazinhas sobre samba, de brincadeira, com os meus colegas... Mas bobagem, coisas mal-acabadas.

Creio que essa parte da rima eu devo ter herdado do meu velho pai, que fazia versos. Era mineiro de Ubá e tinha o dom de fazer poesias, com rimas ricas. Algumas chegaram a ser publicadas no Jornal das Moças, que na verdade era uma revista, não um jornal. Ficava ali perto da Praça Mauá, as pessoas mandavam e a revista peneirava e publicava, e colocaram até um retrato dele junto. Então a parte poética eu herdei do meu velho pai, e em menino já fazia, de brincadeira.

Depois fui morar em Oswaldo Cruz e as coisas se encaixaram melhor, porque ali pertinho tinha a Portela. Eu já ouvia falar de Oswaldo Cruz através do samba do Noel Rosa, da Aracy de Almeida, já rolava alguma coisa com o nome do Paulo da Portela, então, quando eu cheguei em Oswaldo Cruz, eu me senti, assim, como se tivesse chegado... Num lugar certo. Aí eu fui me aperfeiçoando ali, menino, mas tinha que me aperfeiçoar mais, vendo aqueles bambas fazendo aquelas coisas lindas, na roda, cantando, então eu ficava de longe, olhando, sonhando, armazenando na minha cabeça o desejo de um dia fazer um samba para a Portela. Isso veio acontecer aos meus 17 anos, quando fiz o meu primeiro samba, e fui aprovado pelos bam-bambãs, que disseram:

- Esse garoto aí, vamos aproveitar, nós temos que aproveitar essa garotada... Esse aí... Tá bom, canta de novo. Ó, tá vendo, que coisa bonita?

Eu vi, em 1950, a Portela desfilando na cidade com um samba meu, Retumbante vitória, um samba-exaltação a ela. Aquilo pra mim foi uma alegria muito grande, eu ficar atrás de um poste assim, vendo as baianas rodando e cantando meu samba na Praça Onze. Dali é que as coisas foram começando, aí eu fui me tornando parceiro daqueles antigos... Aqueles grandes sambistas dali, grandes compositores, foram me dando primeiras partes pra botar a segunda, eu botava direitinho, fui me tornando parceiro dos que eu olhava assim de longe, e admirava, então o sonho foi virando realidade e, graças a Deus, se hoje eu tenho alguma coisa, na vida artística, o meu aprendizado foi com eles.

Devo muito à Portela, porque foi nela que eu iniciei meus primeiros passos, e... Em 1970, quando formaram a Velha Guarda, eu era bem novo ainda, tinha 37 anos... Inclusive um jornal publicou uma vez: "Monarco, o mais jovem dos patriarcas". Isso causou até polêmica, teve gente que questionou:

- Mas o Monarco, aí?

E alguém defendia: 
- Não, mas ele sempre gostou de compor com os mais velhos, as coisas que ele faz são boas, deixa ele aí com a gente.

O Paulinho da Viola fez aquele disco Passado de Glória e escolheram um samba meu, e o samba inclusive deu nome ao disco. O nome do meu samba era Passado de Glória, o do disco era Portela, Passado de Glória:

Portela, eu às vezes meditando

Acabo até chorando

E não posso me lembrar

Teu livro tem

Tanta página bela

Se eu for falar da Portela

Hoje não vou terminar

A Mangueira é de Cartola, velhos tempos de apogeu

O Estácio de Ismael, dizendo que o samba era seu

Em Oswaldo Cruz

Bem perto de Madureira

Todos só falavam Paulo Benjamim de Oliveira...

Esse samba foi o que entrou no disco... Então, a Velha Guarda se agrupou aí, a partir de 1970, e foi formado um grupo Velha Guarda. Porque a velha guarda do samba sempre existiu, os mais velhos já eram chamados pela gente de "velha guarda". Quando passava um velho, como Seu Antonio Caetano ou Seu Antonio Rufino, que foram fundadores da escola:

- Ih, ó lá, aquele é da velha guarda, aquele é velha guarda...

Mas o grupo musical não existia. A Portela foi uma das primeiras, depois todas as outras escolas copiaram, no que fizeram muito bem, porque a Velha Guarda é sentinela de tudo. É na Velha Guarda que você ainda ouve um samba que era cantado na comunidade, sem ser sucesso de rádio nem nada, mas uma coisa pura... Inclusive o sonho do Paulinho era registrar essas coisas, que estavam se perdendo, muita coisa bonita estava morrendo com os autores. Ele, preocupado com isso, fez esse disco, pra poder registrar essas coisas bonitas, que se faziam espontaneamente, sem pensar em gravar, sem pensar em sucesso, sem pensar em nada, em levantar a galera. Nada disso. Fazia-se com o coração, cantava-se na comunidade e, depois, por ali mesmo morria... Então o sonho do Paulinho era registrar aquelas coisas do Paulo da Portela, do Heitor dos Prazeres, do Manacéa...

Dizia Juarez Barroso, um jornalista que já faleceu: “os sacerdotes do samba de Oswaldo Cruz, que estão vigilantes, contra os perigosos desvios", e não sei o quê, e tal. Ele gostava de falar isso. Eu achava bonito, essas palavras. Apesar de que já desviaram muita coisa aí... É o poder do vil metal, se rouba muita coisa. Mas o papel da Velha Guarda é um papel bonito, de manter acesa essa chama. Desse samba que não é cantado no rádio, é cantando por aí, mas são coisas lindíssimas, que eram feitas lá por aqueles compositores, pessoas modestas, mas que eles tiravam do coração aquelas coisas bonitas... Que muitas até foram para o disco, aí, se comportaram maravilhosamente bem e hoje até virou sucesso por aí. É uma coisa bonita, ela sair dali pra ir pro estrelato. Não é vir de lá de fora pra dentro. Não, não, não. É bonito ela sair dali e as pessoas depois ouvirem:

- Ih, esse samba é lá da Portela, aí, foi gravado pelo Paulinho da Viola, o Zeca Pagodinho tá cantando no rádio. 
Mas saiu dali, do ventre da Portela. Não é pegar as coisas lá do rádio, que já são de outra cultura, e trazer pra dentro do nosso, que é onde a nossa cultura já é de raiz, ali, de nascença. Teve uma época em que andaram deturpando muita coisa, teve diretores lá chamando pessoas do rádio pra fazer samba na Portela. Eles não vão fazer igual ao sambista, o humilde ali. De maneira nenhuma, não vão fazer igual! Podem fazer coisas lindíssimas aqui, no universo deles, que nós também não vamos fazer, compreendeu? Mas eles não vão fazer igual a um compositor ali que pouco freqüentou bancos escolares, mas que tem aquela linha, que parece que é uma dádiva divina, ajudada por Deus. Fazer aquelas coisas lindíssimas, que muitas até vieram pro disco, se tornaram sucesso... Você vê o Passarinho ${ }^{46}$ :

Quero viver como um passarinho

Cantar, voar sem direção

Quando quiser construir o ninho

Hei de encontrar um coração

Por enquanto eu quero viver

Com toda a liberdade

Cantando aqui

Pousando ali

Essa é a minha vontade

Uma coisa pura, do compositor dali do nosso meio, compreendeu? Que, como eu acabei de dizer, pouco freqüentou bancos escolares, mas tem... Uma coisa própria, sei lá... Cartola, que pouco estudou, pra fazer "as rosas não falam, simplesmente exalam" - olha que rima rica - "o perfume que roubam de ti", uma coisa linda. Isso aí é a vantagem que o pessoal do morro teve, a ponto de ser reverenciado, idolatrado, pelo povo, que quis correr para a Praça Onze pra ver essa gente humilde, modesta, desfilar, cantando aquele samba tirado do coração.

Foram surgindo as escolas de samba, encantando a cidade, encantando os olhos do povo, tornando-se uma alegria de graça, sem precisar pagar nada. Naquela época, as pessoas se acotovelavam pra ver as escolas de samba passar, era a alegria do povo, e hoje está aí também, muito embora hoje seja um espetáculo riquíssimo, mas está aí uma festa mundialmente falada, que o carnaval brasileiro não tem igual, os hotéis já começam a superlotar, os barracões cheios de pessoas trabalhando...

Essa é a escola de samba que foi perseguida pela polícia. Eu, garoto, eu ouvia os velhos falar, eu nem cheguei a pegar. Quando eu cheguei na Portela em 1946 as coisas já estavam se acomodando, o Pedro Ernesto já tinha dado subvenção, parece que foi o primeiro Prefeito a dar. As escolas já passaram a ter uma subvenção, uma ajuda, mas que não era grande. Faziam do bolso, pagavam do bolso, aquelas pessoas trabalhadoras, que trabalhavam a semana toda e, quando chegava domingo, o lazer era uma rodada de samba. E a polícia chegava, dissolvia aquilo, a porradas e tudo, e metia dentro do camburão, porque aquilo era negócio de vagabundo.

- Eu vou ali e voltar, se encontrar essa vagabundagem aqui, essa bagunça, já sabe como é que vai ser!

Não era bagunça nenhuma, estavam assim, cantando e brincando, batucando ali, e as moças sambando, aquela coisa toda. Então, eles achavam que aquilo era coisa de vagabundo. Aí a sociedade, as autoridades, começaram a acordar, vendo que

\footnotetext{
${ }^{46}$ Composição de Chatim.
} 
aquilo era uma cultura popular, bonita, que não dava nem despesa, uma coisa pura, começaram a chegar ali perto para pesquisar, pra ver de perto, como na Portela teve o Edison Carneiro, que era o irmão do senador, que era... Folclorista, e foi lá para a Portela. Eu era menino quando Natal mandou buscar o cavaquinho:

- Tem um doutor, aí, que vai vim, aí...

Fazer não sei o quê, não me lembro.

- Tá bem.

Até quem foi junto com ele foi o Lan, o cartunista, que passou em várias escolas, mas quando chegou ali, escolheu a Portela, pela disciplina que ele encontrou lá, pela maneira como foram recebidos. Ele tinha passado no Salgueiro, já tinha passado na Mangueira, ali ele escolheu:

- Não, eu gostei daqui, vou ser Portela.

Aí escolheu a Portela. O Lan é nosso convidado, da Velha Guarda: sai todo ano com a gente. Então a escola de samba passou a ter um "GRES" na frente, Grêmio Recreativo Escola de Samba. Passou a ser um grêmio recreativo, com isso as pessoas já começam a ver no fundo do túnel uma luz:

- Pô, isso aqui é bonito...

O gringo nem tem isso, não tem. Veio uma duquesa da Inglaterra. Quando chegaram aqui, o Itamaraty queria dar balé pra ela, e não sei mais o quê, mas ela disse:

- Não, não quero isso. Eu queria que vocês me trouxessem -

Aí o intérprete:

- Ela quer samba! A gringa quer samba, ela quer sair no samba!

E tiveram que levar a escola de samba lá, a Portela foi lá. O Itamaraty era aqui no Centro, na rua larga, agora é um prédio pequeninho, ainda está lá até hoje. Foi ali que a nêga Pelé sambou, lá, o pessoal sambou para a gringa. Pra você ver o que o nosso samba faz!

E o papel da Velha Guarda é esse, é manter acesa essa chama desse samba humilde, o samba ingênuo, que não é comercial, não é nada disso, não pensa em comercial, nem fazer pra vender. A pessoa tira de dentro do coração... Tem alguma desilusão amorosa, ou uma coisa que ele viu, ali, acontecer, como se fosse um repórter da noite. O Geraldo Pereira:

Você só dança com ele

E diz que é sem compromisso

É bom acabar com isso...

Isso Geraldo viu acontecer mesmo, o camarada chegar com uma mulher no baile e ela se engraçar com o outro cara, só dançava com o cara, e o cara:

- Porra, o que é que há? Vamo dançar...

- Não, peraí, peraí, deixa eu dançar com ele aqui..

- Pô!

- Mas é sem compromisso...

E quando parava pedia bis:

- Mais uma vez!

Aí o cara, pô, perdeu, ela pediu... Aí o Geraldo, no dia seguinte, fez esse samba, uma coisa bonita, verdadeira. Então o papel da velha guarda é manter acesa essa chama. Com velha guarda você não vê correr de escola em escola. Dificilmente você vê um velha guarda sair da Portela pra ir para a Mangueira, ou da Mangueira 
para a Portela, como acontece com os puxadores, mestre-sala e porta-bandeira, que trocam de camisa, de escola, não têm aquele amor que tem um velha guarda, de terninho, direitinho... Aquela disciplina, todos bem vestidos. Na escola de samba, a Diretoria tem respeito por eles, que sabe que eles ali representam os que começaram tudo, não é? Os coroas da antiga aí que, muitos correram de polícia, e tudo, pra hoje a escola de samba estar aí. Portela é uma, Mangueira é outra, as outras não chegaram a pegar isso, pegaram já o filé mignon, mas a Portela já teve ocasião de eles cantarem lá, o tintureiro - a viatura - chegar e:

- Quem é que tá cantando samba? Entra aqui, um por um...

O Alvaiade, por exemplo, correu. Alvaiade era um escurinho de cabelo esticado, Alvaiade correu e aí disseram para ele:

- Ih, Alvaiade, tão procurando um crioulinho de cabelo esticado!

Ele aí raspou a cabeça, para confundir... Tudo isso aconteceu na Portela. Teve outra vez que o Cartola foi reclamar que Mangueira não tinha desfilado, porque o delegado tinha mandado arrancar as bandeirinhas todas, que depois de meia-noite acabava tudo. Carnaval era até meia-noite, hoje vai até de manhã, mas na Praça Onze, tudo embandeirado...

- Acaba com isso! Arranca aquelas ali!

Foram arrancando as bandeirinhas, aí Cartola foi reclamar com o delegado de polícia:

- Mas a Mangueira ainda não desfilou...

E rasgaram a roupa do Cartola, ele saiu triste... Tudo isso contado pelo Carlos Cachaça, um velho que morreu com uma dignidade, aos 97 anos, com um passado limpo, com uma conduta, idolatrado até por Carlos Drummond de Andrade, que disse uma vez que gostaria de fazer um verso que fez o Carlos Cachaça. Heitor VillaLobos! Idolatrava essa gente, a Carlos, a Cartola, Paulo da Portela... Algum valor tem que ter, não é? Senão, não ia ter Villa-Lobos idolatrando.

Veio um maestro polonês, não sei quem, sei que era polonês, que veio fazer um disco no Brasil de folclore, teve chorinho, teve samba, o samba foi o do Cartola, Quem me vê sorrindo, dele e do Carlos Cachaça. Eles gravaram num navio uruguaio, em 1940, por indicação do Villa-Lobos. Ele morava aqui na Graça Aranha e em 1947 eu trabalhava aqui atrás, na ABI - Associação Brasileira de Imprensa. Villa-Lobos jogava bilhar francês ali, um jogo de carambola, sem caçapa, numa mesa, e eu escovava a mesa. Ele tinha o taco dele guardado lá. Todo dia ele estava lá, Nássara também não saía dali, o Barão de Itararé, Aparício Torelly, que é o homem do "entre sem bater"... Essa história é boa: a polícia entrava empastelando o jornal comunista, ali perto da Praça Tiradentes, numa ruazinha que tinha ali. Era o Tribuna Popular, parece, do Pedro Motta Lima, de uma família de comunistas, que a polícia perseguia, e o Barão de Itararé pôs isso: "entre sem bater". Compreendeu? Mas era sem bater, sem dar porrada. Hoje você vê em consultório médico, mas aquilo era pra não bater mesmo, que eles andavam acabando com tudo.

O Barão de Itararé andava com a perna meio presa, parrudão, gostava muito de ler. Ele sentava, ficava lendo, não jogava sinuca, nem ia lá perto da sinuca, só ficava lá na parte do jornal. A ABI era alegre. Eu conheci ali pessoas... O Abdias do Nascimento, que é um líder negro, não saía de lá, Austregésilo de Athayde, que foi presidente da Academia Brasileira de Letras. Eram pessoas que depois é que eu fui 
vendo que eram homens importantes, quando eu era garoto não sabia da importância deles. O pai do Collor, Arnon de Mello, gordinho, baixo, Governador de Alagoas; Vivaldo Palma Lima, falei isso em Alagoas um dia desses, e um sujeito falou:

- Ih, tem um estádio ali, Monarco, o Vivaldão, é em homenagem ao velhinhozinho...

Raul Pederneiras, era do Jornal do Brasil... Pessoas importantíssimas do nosso jornalismo. Eu, garoto, não sabia onde estava entrando. O Villa-Lobos, para mim, era um homem qualquer, depois é que eu fui entender, tem gente que não acredita, mas estava lá na $\mathrm{ABI}$, eu levo lá no décimo andar, e aponto:

- É essa mesa aqui, ó.

Tinha uma mesa de sinuca aqui, o bilhar francês no meio, e outra mesa de sinuca aqui; a dele ficava no meio... Charuto, cansei de buscar charuto pra ele, Havana, do bom, contava baralho pra eles jogarem pôquer ou buraco, sei lá, aqui no Jóquei Clube. Teve um jornalista que disse:

- Olha, eu vou te ensinar um truque pra tu ganhar um dinheiro: tu compra esse baralho, vai no Jóquei Clube....

Que ali eles jogavam uma vez só, e trocavam de baralho, ficava aquele baralho novinho. Aí, custava oito pratas, eles me davam dez, eu ficava com dois mil réis, uma coisa lícita. Eles mesmos falavam pra mim, mandavam comprar:

- Não compra, não! Vai lá no Jóquei Clube, você ainda vai ganhar duas pratas.

Aí eu ganhava, comprava três baralhos e ganhava seis mil réis... Seis mil réis é muito dinheiro, o bonde era duzentos réis, por aí, ainda me sobrava um dinheirinho pra almoçar e jantar, às vezes ainda levar um pãozinho pra ajudar a minha velhinha.

Então aí, voltando à escola de samba: o papel da Velha Guarda é esse: é um papel honesto, sincero, de manter a tradição da escola. Foram eles que começaram tudo na época da maré braba, quando ninguém queria saber de escola de samba. Hoje, você vê a escola de samba, é Suzana Vieira, e não sei mais o quê, todo mundo querendo aparecer... Mas antigamente, se namorasse uma moça e fosse de escola de samba, o pai já entrava:

- Cuidado, hein? Esse cara anda metido em escola de samba...

Então a escola de samba, pra eles, era uma coisa do mal. Você cantava um samba, no meio da gozação, samba de morro:

- Ih, esse cara anda metido com negócio de samba, cuidado!

Tocador de cavaquinho, essas coisas, não tinha. O samba sofreu muito. Hoje é o patrimônio cultural do nosso país, mas a gente sofreu horrores. Estou feliz, hoje eu tenho um certo reconhecimento, já me chamam pra fazer show em Alagoas, agora vim de São Luiz, me chamam para Fortaleza, aí para fora... Já estou com 76 anos. A caminhada foi longa, mas estão me dando um reconhecimento. Não sei se é pela minha obra que tem aí... Porque eles escutam o meu samba, mas não sabem que é meu. Quando eu canto:

- Mas isso é dele? Isso também é dele? Isso também é dele?! Pô!

Aí passam a acreditar mais no taco, porque tudo precisa de qualidade. Não adianta, o camarada compra este copo aqui:

- Ah, ele pagou 50 merréis naquele copo, pra quê? Esse foi cinco mil réis, quase a mesma coisa! 
Depois quando ele vai pegar o copo... Opa! Quebrou todinho. Alguma coisa tem aquele, é a qualidade. O meu samba não tem agrotóxico, é um samba tirado do coração, e eu me preocupo, ao compor. Vulgarizar a minha obra, não gosto; ir pro modismo, também não vamos, a nossa Velha Guarda se preocupa em manter a nossa linha. Cantamos as coisas de nossos ancestrais. Coisas lindíssimas que ficaram. E deixa quem quiser falar! Deixa quem quiser falar. A rádio não quer tocar? A gente canta na esquina! Traz os pandeiros, o violão, vamos ali para a esquina e começamos a cantar, a brincar, daqui a pouco está todo mundo brincando. Às vezes o rádio faz sucesso numa mentira, mas tem um prazo de validade, que de repente você procura - e quedê? E o nosso está aí. Eu faço show aí, canto samba de 1930, 1940, Paulo da Portela:

Serei teu ioiô

Tu serás minha Iaiá...

Isso é de 1932.

Quitandeiro

Leva cheiro e tomate

Na casa do Chocolate

Que hoje vai ter macarrão

Isso também o Paulo fez idolatrando um amigo que pediu a ele pra levar uma turma lá pra fazer uma roda de samba na casa dele, e ele fez isso como reverência, como brincadeira, para chegar lá cantando isso. É uma coisa verdadeira, uma coisa bonita:

Prepara a barriga macacada

Que a bóia tá enfezada...

Chega só trinta litros de uca

Pra fechar a butuca

Desses negro beberrão...

Coisas assim, feitas com o coração. Então o nosso samba, graças a Deus, está aí, não é? Está no caminho dele, e está bom.

Os discos da Velha Guarda da Portela? Todos os dois, o disco de 1970 e o de 2000, são bons. O Paulinho teve o cuidado na garimpagem, de gravar aquelas coisas bem antigas. O Paulinho é um... Cabeça. Ele ouviu e escolheu, ele mesmo escolheu o repertório, e todos os compositores cantaram no disco: Alcides, João da Gente, que já se foram, Ventura, que foi o primeiro responsável pela Velha Guarda, que dizia:

- Olha, vamos, mas é com o blusão de bolinha, hein?

Depois do Ventura, passou para a mão do Manacéa, do Manacéa passou para a minha mão. Eles foram se indo... Foi o Alvaiade, que foi o diretor de harmonia da Portela, Alcides, João da Gente, Ventura, Alberto Lonato, todos já se foram... Vicentina, que era a única pastora nossa, papai do céu levou. Então, está difícil, o grupo musical da Velha Guarda está diminuindo, nós perdemos agora cinco baluartes. Perdemos a Doca, perdemos o Casemiro da Cuíca, perdemos Jair do Cavaquinho, perdemos Argemiro Patrocínio... E Casquinha está no estaleiro, Cabelinho está no estaleiro, Eunice está no estaleiro. Então nós estamos aí com 10 pessoas. Botar no lugar, nós só podemos botar pessoas que tenham um passado glorioso, não é qualquer um. A renovação é difícil. Era mais fácil antigamente. Porque agora estão morrendo as pessoas, e a gente tem que ter cuidado com os que estão lá, porque o camarada não pode chegar lá pra cantar coisa que não tem nada a 
ver com a gente. Vai descaracterizar, e nós temos uma identidade, tem que estar com muito cuidado. Para não chegar amanhã:

- Pô, mas isso é que é a Velha Guarda? Poxa!

Nós cantamos aquilo que a gente sente que deve cantar, que faz bem à gente. Quando chega alguém querendo mudar, a gente fala logo:

- Não, num vai cantar isso aqui não. Aqui não. Canta pra lá.

Então não se mistura com a gente, não pode se misturar.

Mulher ingrata? Ah, sim, tem muita mulher ingrata nos sambas da Velha Guarda. Tem, mas como tem. Não é tudo real. A gente inventa bastante. Tem coisa que é história. Algumas coisas são verídicas, mas a maioria também é história, porque muita coisa a gente faz, assim, que não aconteceu. Ou se retrata, às vezes uma pessoa também está passando por aquilo, você faz como se estivesse acontecendo contigo, compreendeu? Então a gente tem que estar sempre criando, realmente. E são mais as desilusões amorosas... O Juarez Barroso falava isso:

- Monarco é gozado: a mulher vai embora, ele faz um samba; vem outra, ele enaltece a chegada daquele novo amor.

E... Então eu gosto de falar essas coisas, que o samba é lamento, a gente lamenta, tem aquela dor de cotovelo. Também de enaltecer a Portela. A gente inventa, tem que criar, com organização, direitinho, para que as pessoas gostem. A gente fazia aquilo para poder cantar e as pessoas gostarem, e a gente levar aquilo à frente. E o samba, quando é bom, a música quando é boa, ela vai caminhando sozinha, um escuta aqui, fala pro outro ali, fala pro outro ali, o outro fala pro outro lá, quando vê:

- Pô, como é aquele samba que tu cantou? Me falaram que tu tava com um samba bonito, canta... Ih, rapaz, que bonito!

Então é assim, o artista, alguém fala, ele aí já quer ouvir, aí você passa pro artista, o artista gostou, canta, vai pro disco. É um processo bonito, vai pro disco, se comporta bem ali, vai pro ouvido das pessoas, que aprendem. E às vezes mexe com a sensibilidade de uma pessoa que está passando por aquilo, eu às vezes estou parado aí na cidade, e alguém diz:

- Poxa, Monarco, a tua música, eu vou te dizer uma coisa. Você tem um samba que parece que você fez pra mim...

Eu digo:

- Ah, muito obrigado!

A gente tem o cuidado, de fazer direito, fazer... A melodia forte... Num momento inspirado, quando dá sorte de vir uma inspiração, nascer, é muito bom, muito gratificante, você fazer um samba e mostrar pra uma pessoa, e aquela pessoa gostar:

- Pô, gostei, tá bonito, hein?

E aquilo vai andando, vai andando, e quando vê... Aí você começa a cantar, as pessoas vão aprendendo, aí chega até no disco, vira sucesso nacional. Já aconteceu comigo, de músicas minhas serem tocadas, assim. Antes a gente fazia lá na Portela, fazia por ali, guardava por ali mesmo. Quando o samba começou a ter uma vêzinha, uma colher de chá, aí eu comecei a meter a mão no baú, tirando aquelas coisas. Que a música não envelhece. Uma música, quando é bonita, ela não envelhece. Você pondo uma roupagem nela assim, um jeitinho ali, bota um arranjozinho aqui, e ela vai pro 
disco de novo e ela continua a ser aceita pelos ouvidos, pelas pessoas, e assim sucessivamente. Que a música é uma coisa bonita. É divina, não é? E o lamento nosso, a queixa, é através de um samba:

Perdi meu grande amor

Não sei o que será de mim

Quando é aquela coisa que a gente faz, se lamentando...

Numa estrada dessa vida

Eu te conheci, oh flor

Vinhas tão desiludida

Mal-sucedida

Por um falso amor

Dei afeto e carinho

Como retribuição

Procuraste um outro ninho

Em desalinho

Ficou meu coração

Meu peito é só paixão

Meu peito agora é só paixão...

Essa eu fiz com Ratinho. Isso aí, o que é? O camarada encontra uma criatura tristonha, da vida, ele pega, ajeita, dá tudo, apoio, e ela amanhã se vai com outro, e aquele fica triste, diz:

- Poxa, chegou aí, num tinha nada, eu fiz, eu pus lá...

Aí ele se queixa, através do samba. Ah, isso aí acontece muito, na vida da gente. Como também às vezes uma ingratidão da parte nossa, também, acontece. Depois cai e lamenta:

- Eu não devia ter feito assim, ela num merecia!

Aí... Tem uma canção que eu gosto muito:

Se Deus um dia olhasse a Terra

E visse o meu estado

Na certa compreenderia

O meu trilhar desesperado 47

As coisas bonitas que foram feitas pelo pessoal do rádio, aquelas canções, aqueles sambas-canção que Orlando Silva cantava, daquela turma boa que tinha aí, Mário Lago, Custódio Mesquita, sem falar nos bem antigos mesmo, de lá de trás, Cândido das Neves, que minha mãe cantava aquelas coisas. Eu ficava assim, vendo minha mãe cantar aquilo, lavando roupa, tadinha, ali, cantando:

Eu ontem rasguei teu retrato

Ajoelhado aos pés de outra mulher

Achava aquilo bonito...

Eu sei também ser ingrato

Meu coração também já não te quer

Eu ontem rasguei o teu retrato

Ajoelhado aos pés de outra mulher

$\mathrm{Eu}$ achava aquilo bonito. E uma vez papai quis bater nela, porque ela cantou, até fui saber mais tarde que era do Custódio Mesquita, mamãe estava sofrendo muito

\footnotetext{
${ }^{47}$ Caprichos do destino, de Pedro Caetano e Claudionor Cruz.
} 
com meu velho pai, que Deus ilumine os dois onde eles estiverem. Aí ela cantou... Porque a mulher, também, não é mole, quando ela quer machucar o coração, com o jeitinho dela... Ela está sofrendo daqui, mas quando chega a vez de ela espezinhar o homem... Hahn! Para mulher não tem malandro, não tem nada disso, não. Aí mamãe cantou lá no tanque de roupa, e ele estava lá na plaina dele fazendo a marcenaria dele. No que ele escutou, ele parou tudo, quis bater nela, que ela cantou...

Junte tudo que é teu

Teu amor, teus trapinhos

Teus trapinhos, olha!

Junte tudo que é teu

E saia do meu caminho

La lá la la

Aí...

- Pô, você tá cantando isso pra quem? Cê tá cantando isso pra mim!

- Não... José, tô cantando porque toca no rádio!

Mentira! Ela estava cantando era pra ele mesmo, mas aproveitou o ensejo. E ele ficou agoniado, quis bater nela e tudo, eu era pequeno, ela contava pra gente depois. Ela cantou isso, mas ela cantou pra alfinetar. A mulher sabe machucar.

Às vezes um tem uma desilusão com a escola, mas o sambista é democrático. O samba tem um negócio muito bonito. Zé Katimba? É meu amigo, saiu com a gente num carro. O sambista de uma escola se dá com o sambista de outra, aí quando chega um momento desses, às vezes uma escola acolhe mesmo outra. Chegou:

- Ah, sofri uma desilusão lá, tô chateado..

- Fica aqui com a gente, rapaz. Cê quer sair com a gente?

Então é como se fosse uma guarida, num momento difícil, um ombro amigo, uma coisa qualquer.

- Fica aqui com a gente.

Aí ele pegou e disse

- Ah, Monarco, eu aceito sim, eu vou sair com vocês.

Depois voltou à Imperatriz Leopoldinense. Eu falei mesmo pra ele:

- Katimba, fica à tua vontade. As portas aqui estão abertas, mas se você quiser voltar pra tua casa, volta que aquilo ali é teu também. Cê tem um quinhão ali, de luta, já é da fundação, esquece algumas coisas, faz vista grossa pra alguma coisa e volta novamente.

E ele voltou, diz o ditado, "o bom filho à casa torna". Voltou, mas ele encontrou na Portela um apoio num momento difícil da vida dele, compreendeu? Como outros foram para a Mangueira, muitos mangueirenses foram para a Portela. Por uma questão, às vezes, de se aborrecer, de não aceitar certas coisas. Mas não é atrás de dinheiro, não tem passe. É por uma questão de aborrecimento. E aí, depois ele aparece na cidade, com uma roupa daquela outra escola, alguém vê e vai dizer lá:

- Poxa, fulano saiu na Portela..

Então, na volta dele, já foi recebido com mais respeito. Ele reclamava muito da Imperatriz, que estavam tratando ele mal lá. Aí eu peguei e ofereci apoio. A Beth Carvalho, quando aconteceu aquele negócio do carro, que o camarada expulsou ela no desfile da Mangueira, eu lá no barracão falei com o presidente. E o presidente:

- Você tem o telefone da Beth aí, Monarco?

Eu digo: 
- Tenho.

- Liga pra ela, convida ela pra sair na Portela.

Aí eu liguei.

- Não, Monarco, agora não, deixa isso pra mais tarde. Eu ainda tô de cabeça quente, mas muito obrigada, eu agradeço de coração.

Convidamos ela pra sair na Portela com a gente, que ela gravou muito a gente. Gravou mais a Velha Guarda da Portela do que a Mangueira, a Beth. Ela gosta da Portela.

Os sambistas se dão muito, muito embora sejam de outras escolas. Ontem mesmo fui lá no barracão da Grande Rio, com Zeca Pagodinho. Fui recebido com o maior carinho, pelo Helinho, presidente lá, e o Jarbas. Me trataram com muito carinho, almocei com eles lá, depois vim-me embora. Não vou sair lá porque eu sou Portela, mas eles sabem que minha intenção também não é maligna, de ir bater no barracão deles pra fazer nada errado, nem comentar nada contra, nem sair por aí falando. Eles sabem do meu procedimento no samba, graças a Deus, todos eles me respeitam. E tive parceiro, por exemplo, na Mocidade Independente de Padre Miguel, o Toco, e no Império Serrano, o Hélio.

O sambista tem isso, ele é de uma escola, mas ele tem música com o de outra. Acaba o desfile, uns se abraçam, vamos beber juntos e tudo. Só na hora, cada um luta pela sua, mas acabou ali, não tem briga. Tem uma coisa pura, uma coisa bonita, que não existe no futebol. No futebol estão se matando. Escola de samba, não. Uma escola visita a outra, sabe? Mangueira vai à Portela, Portela vai à Mangueira, isso já vem, essa relação já vem do Paulo com o Cartola. Eu cheguei a fazer Velhas Companheiras inspirado nisso. Eu passei em frente à Mangueira mesmo, olhei para a quadra da Mangueira, aí bateu a idéia na minha cabeça e eu fiz:

Quando passo em frente à Estação Primeira

Me lembro da velha Mangueira

Lindos sambas, tudo enfim

Me lembro dos meus tempos de menino

Quando o Paulo e o Rufino, Marcelino e Gradim

Trocavam toda a cordialidade

Estreitando os nossos laços de amizade fraternal

Por isso que Portela e Mangueira são as grandes pioneiras

Das escolas no Carnaval

Em noitadas lindas, já presenciei

Os sambistas com emoção

Como já dizia o bom Cartola

Ponto alto da escola, "sala de recepção"

Tremulavam juntas nossas bandeiras

Velhas companheiras semeando a paz

Por isso que Portela e Mangueira

Sempre foram as primeiras

Dos idos Carnavais

De ver a amizade da Portela com a Mangueira, eu faço um samba. É uma coisa bonita, não é? Eu uso aí uma palavra do Cartola, mas cito que foi ele que disse. Eu não uso aquilo pra mim, não: "como já dizia o bom Cartola, ponto alto da escola, sala de recepção". "Mangueira é uma sala de recepção, aqui abraça-se o inimigo como se 
fosse o irmão", compreendeu? O Cartola fez, quando o Paulo esteve por lá. Paulo se aborreceu na Portela, foi para a Mangueira, ficou lá com o Cartola, uns dias, mas o Cartola insistia que ele devia voltar, que a Portela era dele, ele quem criou, foi ele quem deu tudo, que embalou a Portela. Então o Cartola insistia, mas o Paulo estava muito chateado e não voltou mesmo não... É, ele fez:

O meu nome já caiu no esquecimento

É verdade, é lindo. E para não ser esquecido, justamente, foi uma maneira. Ele fez:

O meu nome já caiu no esquecimento...

A velhice vem chegando

Já me olham com desdém

Olha: desdém!

Ai, quanta saudade

De um passado que se vai lá no além

Chora cavaquinho, chora

Chora violão também

O Paulo no esquecimento não interessa a mais ninguém

Chora Portela, minha Portela querida

Eu que te fundei, serás minha toda a vida

Aí eu faço:

O teu nome não caiu no esquecimento, nem cairá

Fiz esse samba dolente pra te adorar

Paulo seja sempre iluminado por nosso Senhor

Aqui na Terra te adoramos com fervor

E lá no reino da glória descansa em paz

Que a tua Portela não te esquecerá jamais

Não gravei isso, não. Está no meu baú guardado. Esse eu cheguei a botar num festival, mas fui classificado com outra música e esse ficou de lado. Mas quando eu canto todos gostam... Tem a segunda parte, mas isso aí eu vou botar numa fita direitinho. E guardar pra mim, pro meu baú.

Deu pra fazer alguma coisa? 
Serginho Procópio em roda de samba. Acervo pessoal da autora, dez. 2010.
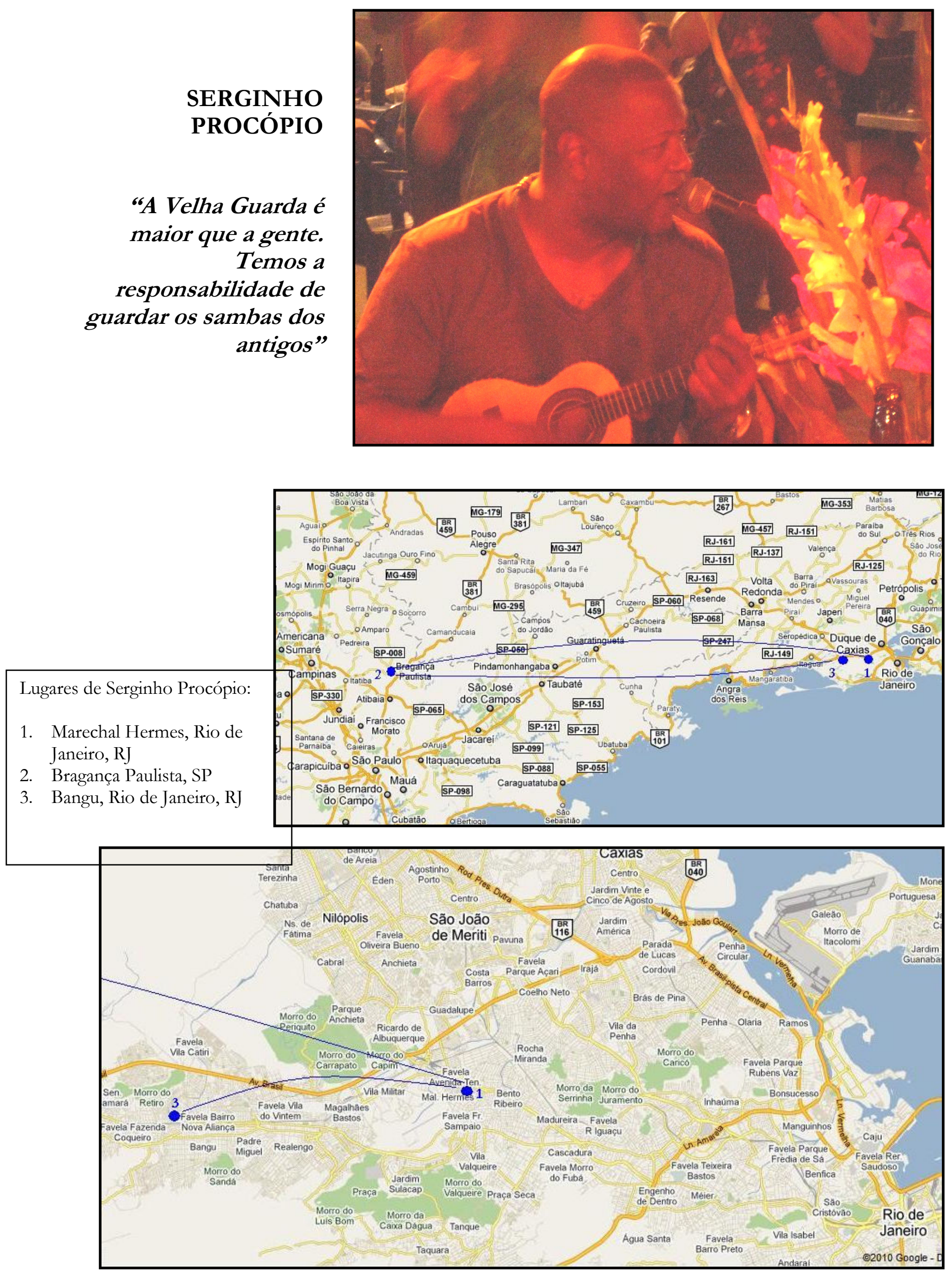
Minha história na música vem desde pequenininho; meu pai era músico, meu avô também foi músico, compositor de chorinhos. Alguns gravados, como Gadu Namorando, que foi gravado pelos Carioquinhas e mais um montão de gente. A minha história na música vem por aí, meu pai tocou com Candeia muitos anos, pertencia à Velha Guarda da Portela e, depois do falecimento dele, me convidaram pra entrar no lugar dele, porque eu já era músico, já era compositor também, já tinha músicas gravadas e tocava por aí. Eles me convidaram pra entrar e eu aceitei.

Mas até lá, ainda teve minha história como pequenininho, minha mãe conta que quando eu era pequeno, eu sempre arrastei um cavaquinho, e meus tios falavam:

- Quê que cê quer tocar quando crescer, rapaz?

- Eu vou tocar ca-vaco...

Tinha até uma tia minha que só me chamava de Cavaquinho, era meu apelido na família, e essas coisas de criança, sambar com o braço cruzado:

- Samba aí!

Aí tinha que - ha! - tinha que sambar, era coisa muito engraçada. A minha vida foi, mais ou menos, crescendo em torno da música, do samba, né? Com meu pai, sempre acompanhando os mais velhos.

Eu também fui seminarista, eu queria ser padre, porque eu freqüentava muito a igreja católica e, durante uma parte da minha vida, eu achei que era a minha vocação, então resolvi entrar no Seminário. Fui seminarista durante dois anos e meio. Terminei o $2^{\circ}$ grau lá e ainda fiz meio período de Filosofia, quando eu desisti. Mas nesses dois anos, a música, o cavaquinho, sempre me acompanharam. Tinha uma viola lá no Seminário, com um montão de cordas, uma viola espanhola, e dali eu fiz um cavaquinho, botei a viola com quatro cordas e fiz um cavaquinho... E nas missas, a música de Ação de Graças era um samba do Luiz Carlos da Vila, Por um dia de graça. Era uma revolução dentro do Seminário, isso em... 1982, 81, por aí. Era:

Um dia, meus olhos ainda hão de ver

na luz do olhar do amanhecer...

Era a música de Ação de Graças da gente lá. Dali eu desisti, e aí a música, o samba, foi tomando mais corpo na minha formação.

Sempre morei em Marechal Hermes, no mesmo endereço. Mas, nessas minhas andanças aí, morei no Seminário, em Bragança Paulista... Eu vinha para cá nas férias. É até engraçado: acho que meu pai pensava que eu ia ser meio afeminado, então, quando eu chegava e ia com ele pro samba, ele queria me apresentar tudo quanto é mulher ao mesmo tempo. Ele pensava que o filho dele ia jogar pro outro time...

Eu nunca tive medo de me arriscar na vida, e o Seminário foi uma coisa nova. $\mathrm{Eu}$ participei de um encontro vocacional e descobri que ali as pessoas eram exatamente do jeito que eu era, então eu achei que era a minha vocação. Acho que foi a primeira grande decisão da minha vida, comecei a caminhar com as minhas próprias pernas a partir dali. No Seminário eu vinha pouco em casa. Morava e estudava lá, mas eu aprontava, também, bastante. Aprontava muito, muita coisa. Achava que era a minha vocação, mas depois eu fui descobrindo que, além de não ser, eu estava tirando vaga de alguém. Aí eu resolvi desistir.

Para entrar no Seminário, na minha época, você participava de um encontro vocacional, decidia se queria ser, ou não, e ia ver conforme as vagas que dessem na 
sua faixa de escola, pela sua escolaridade. Lá dentro a gente tinha os horários: horário de acordar, oração, café da manhã, horário da escola, horário de trabalho, horário para tudo. Isso no Seminário Menor, que é até o $2^{\circ}$ grau. Já no Seminário Maior, você começa a participar de outras coisas, você tem as aulas de Filosofia e fica mais ligado aos trabalhos dentro da comunidade. Se bem que, no Seminário Menor, você tem as suas responsabilidades com a comunidade, com a igreja, mas no Seminário Maior, você já fica mais ligado a outros tipos de trabalho dentro da comunidade. Conforme você vai avançando na sua formação, seriam quatro anos de Filosofia, depois quatro de Teologia. Aí você vai se aprofundando mais, dentro da sua religião, da Ordem a que você pertence. Minha Ordem era agostiniana, eu pertencia aos seguidores de Santo Agostinho. Aí você ia se aprofundando mais, ia aprendendo mais coisas e, depois disso, você ainda tinha um ano de noviciado. Até ver se realmente queria ser padre, dava uns dez anos, por aí.

Minha mãe é ao contrário, minha mãe é mãe de santo, ligada à umbanda. E ela nunca foi contra, ela sempre me levou para a igreja. Eu não sei como é, é engraçada essa junção entre essas culturas. Não sei explicar isso aí. Mas eu acho que vem... Essa formação das pessoas serem umbandistas, ou religiosas de espiritismo, junto com a igreja... Todo mundo é batizado, quase todo mundo é batizado na igreja católica. Mas depois se criou um conflito dentro da minha casa, porque depois de um tempo meu pai passou a ser crente. Aí ele com minha mãe - eles sempre moraram juntos entravam em discussões por causa de religião, mas os dois se gostavam, se davam bem. Mas quando tinha alguma coisa:

- Você adora imagem!

Esse tipo de coisa. Acho muito engraçado, mas não sei explicar. Minha mãe é viva, e está sempre procurando os centrinhos dela lá, de umbanda.

Freqüentar a Portela era uma coisa mais do meu pai, minha mãe ficava mais em casa com a gente. Ele saía muito, minha mãe não, minha mãe nunca foi de sair muito. Ia às vezes num show da Velha Guarda, no Teatro João Caetano... Meu pai, além da Velha Guarda, tocou com muita gente, Candeia, Elza Soares, Clara Nunes, João Nogueira, um montão de gente, então, às vezes, nos shows que ele ia, a gente, minha mãe ia junto. Quando era essa coisa mais teatral, assim. Negócio de clubes, grandes festas; de noite, ela não acompanhava.

Minha mãe só aprecia música. O meu avô, pai dela, era responsável por Folia de Reis. Minha mãe é de Miguel Pereira e o pai dela tinha, lá em Miguel Pereira, a Folia de Tião Costa. Diz ela que, quando as pessoas viam a Folia de Tião Costa, nêgo corria por dentro do mato; se viesse outra Folia, eles corriam, porque o meu avô, eu não sei como é que é isso, mas acho que quem cantasse primeiro num sei o quê lá, a outra Folia tinha que saudar todos os santos para poder passar. E meu avô tinha muita coisa, assim, de reza. Ele tinha reza para a dona da casa abrir a porta para a Folia dele tomar café, tinha muita coisa. Minha mãe era muito ligada a isso aí. Até acho que a minha formação musical também é por causa disso. Meus dois avôs músicos, ligados a cultura, meu pai... O meu outro avô também tocava violão, tocava cavaquinho, o pai dela. E a minha mãe é mais ligada a essa cultura aí. E ela não gosta de dizer, mas eu tenho certeza que minha mãe canta bem. Ela canta os pontos... Eu lembro mais ela cantando pontos de macumba, mas ela cantava bem. Até hoje em dia quando eu estou perto dela eu forço para ela cantar, ela: 
- Ah, eu não!

Fica meio com vergonha. Mas eu tenho certeza que ela seria uma boa cantora. Certeza.

Eu não continuo sendo católico, mas tenho uma religião, eu sou espírita também, sou muito mais freqüentador de candomblé... Não posso nem dizer que hoje em dia eu tenho uma religião, mas tenho alguma religião ainda. O brasileiro não tem só uma religião. Eu sou muito ligado, eu gosto de freqüentar o León Denis ${ }^{48}$, eu freqüento candomblé e também a igreja católica, nem sempre nessa mesma disposição um ou outro, e nem sempre, sempre. Mas eu sou muito mais ligado a isso, hoje em dia.

Tenho três filhos, duas meninas e um menino. E uma neta, né? É, essa minha mais velha, ela já, também não está mais morando aqui. Ela teve uma menina há pouco tempo, ela está com... 16 anos. Não foi o que a gente queria para ela, mas foi o que ela achou para vida dela. Deus nos deu essa pequenininha e a gente está ajudando no que pode.

Desde criança, eu sempre ia à Portela com meu pai. Lembro de Natal, meu pai naquela maré braba, pedia dinheiro emprestado ao Natal. Depois ele ia pagar, mas o Natal não queria receber, não recebia. Mas meu pai sempre com aquele negócio de ir lá pagar, falava com aquela voz assim:

- Tenho que pagar o Seu Natal...

E me lembro desde pequenininho, freqüentando a Portela. Mais em dias de festa, porque eu era pequeno... Eu sou o penúltimo de uma família de seis; abaixo de mim, só tem meu outro irmão. E meus irmãos mais velhos freqüentaram mais a Portela, negócio de ir à noite, eu ia mais em dia de festa, lembro da Dona Vicentina... A gente chegava, já ia por trás - meu pai era muito olho grande, comia muito - então a gente ia por trás para já almoçar, e depois participar da festa. Eu me lembro mais da casa do Candeia, onde a gente ia mais. E ele estava sempre lá, na porta de casa, chamando meu pai. Parava com o carro lá na porta, eu brincando ali na frente, e ele:

- Osmarzinho, vai lá chamar teu pai!

Eu já sabia que era pra sair, então ficava perturbando meu pai:

- Pai, deixa eu ir com o senhor!

Meu pai nem respondia.

- Deixa eu ir com o senhor!

Aí me fazia levar:

- Leva meu cavaquinho.

Até lá na frente, eu levava o cavaquinho dele, aí ele saía e eu ficava chorando. Às vezes eu ia com ele, lá para a casa do Candeia, muitas vezes, aí, participava daquela roda de samba, via as coisas acontecerem, Casquinha, Seu Jorge do Violão, eu lembro muito disso, eles cantando partido-alto, versando, isso é uma das coisas que eu lembro. Fui crescendo nesse ritmo.

Depois do Seminário eu, por intermédio do meu pai, conheci um músico chamado Paulão 7 Cordas, que hoje é o diretor da banda do Zeca Pagodinho. E esse músico, Paulão - isso foi em 1987, 1988, quando eu estava entrando na faculdade -, eles estavam fazendo um disco em homenagem a 10 anos sem Candeia, esse disco saiu até pela Funarte, onde eu conheci Tuninho Galante. E eu fui com meu pai,

\footnotetext{
${ }^{48}$ Centro Espírita León Denis, em Bento Ribeiro.
} 
porque meu pai era um dos maiores conhecedores da música do Candeia, pela afinidade que ele tinha com o Candeia, de tocar junto. O Candeia fazia uma música e ligava logo pro meu pai ir para lá, pagava um...

- Ô Osmar, pega um táxi aí, pega o Jorge e vem pra cá.

Então, quase que diariamente ele ligava lá pra casa. Meu pai também era estofador, então estava trabalhando lá, aí parava o que ele estava fazendo e ia lá para a casa do Candeia, quase sempre. Na semana, vamos supor, a semana de segunda a sexta, são cinco dias, em quatro dias acontecia isso. Então ele estava sempre lá, e essa afinidade fez com que a gente fosse convivendo com os bambas, né? Aí quando foi fazer esse disco, o meu pai, como grande conhecedor, foi passando as músicas, até para passar pros produtores, como é que era a música, o ritmo, a letra, a melodia... Então meu pai, como conhecedor, passava para eles, e numa dessas reuniões, que foi lá na casa do Carlinhos Vergueiro, lá no Jardim Botânico, o Paulão estava. Estavam o Paulão, a Cristina Buarque, o Carlinhos Vergueiro, eu e meu pai. Acho que foi até a última vez que eu vi o meu pai tomando um copo de cerveja na vida. Meu pai bebia muito, e quando saía com o Candeia, então... Todos eles, naquela época, bebiam muito. E meu pai resolveu que ia parar de beber, nesse dia foi a última vez que eu vi ele beber, ele parando e eu começando. Nesse dia a gente parou no bar, ele aí:

- Ó, vou pagar a do Serginho aqui.

Ele tomou um, meio copo de cerveja. Daí eu nunca mais vi meu pai bebendo. Acho que ele parava ali e eu começava... Hoje em dia eu também não estou bebendo. E eu lembro que o Paulão estava lá, me deu o telefone dele e falou que ia me ensinar a tocar. E realmente aprendi música com o Paulão, violão... Eu já tocava cavaquinho, mas não era nada profissional, tocava de ouvido. Aliás, o que eu sei de cavaquinho, apesar de eu ter aprendido violão com o Paulão, muitas coisas, no cavaquinho, eu aprendi sozinho, vendo, ouvindo... E através da música que eu tinha aprendido com o Paulão - porque a música é uma coisa só - eu aprendi e passei pro cavaquinho, fui descobrindo, acabei aprendendo a tocar. E daí minha vida começou a andar, eu toquei com o Agepê durante 10 anos...

E Serginho Procópio foi começando a caminhar sozinho. Porque muito tempo da minha vida eu fui o filho do Osmar, mas aí eu comecei a aparecer sozinho, conheci o Zeca Pagodinho, por intermédio da Velha Guarda também, na casa do Argemiro, a gente começou a fazer música, aí eu comecei a gravar, apareceram outros parceiros... E antes eu assinava só como Serginho, mas por causa de negócio de direito autoral - Serginho tem um montão aí, na hora de você receber seus direitos autorais, nem sempre pode vir pro Serginho, só. Coloquei meu sobrenome, como meu nome artístico, Serginho Procópio, foi aparecendo, fui gravando, dando seguimento à minha vida.

E eu sempre fui fã da Velha Guarda. Lembro muito de um vizinho nosso, o Seu Alvaiade, que na Portela ele era como se fosse o substituto do Paulo da Portela. Mas ali eu sempre me lembro daquele senhor que todo dia de manhã chamava meu pai lá em casa, Seu Alvaiade. E a minha casa era sempre freqüentada por eles ali. Antigamente não tinham muitos músicos que tocavam cavaquinho, então como meu pai tocava, e tocava bem, a maioria dos compositores, para fazer fita, procurava meu pai. Iam à minha casa com gravadorzinho, pro meu pai acompanhar, e a gente estava sempre acompanhando, era Wilson Moreira, Alvarenga, Alvaiade, e a gente foi 
crescendo nesse meio musical, eu e meus irmãos. Eu mais, porque além de tudo eu tinha aquela vocação natural para a música, né? Da minha família, dos meus irmãos, fui o único músico, apesar de sermos seis. Tenho outro irmão que toca, mas não profissionalmente. $\mathrm{O}$ único que levou a vida da música como profissional fui eu. $\mathrm{E}$ dali, a gente foi crescendo, sempre acompanhando a Velha Guarda, por causa do meu pai também, e sempre crescendo... O Monarco, essas pessoas, nos viram pequenos. Eu então, que estava sempre acompanhando o meu pai, e depois fui ser músico...

O meu pai era também autodidata, então, depois de eu ter estudado com o Paulão, muitas gravações que apareciam, principalmente quando era o Paulão que produzia, ele já mandava as cifras, aí eu explicava ao meu pai como é que era, para quando chegasse na hora de gravar, não perdesse muito tempo, entendeu? E assim fui crescendo, aí, infelizmente eu vim a perder meu pai. Por mim ele estaria tocando até hoje lá, na Velha Guarda, mas eu também me sinto muito orgulhoso de poder têlo substituído. Que ali, parece que é uma coisa de família, eu tenho muito orgulho de dizer que, apesar da pouca idade, eu pertenço à Velha Guarda. E aí fui crescendo nesse meio musical, fui aparecendo para a música, já não era mais o filho do Osmar do Cavaco, já era o Serginho Procópio, e as coisas apareceram naturalmente, não foi nada forçado, fui crescendo naturalmente, conforme as pessoas da minha idade iam aparecendo, assim.

A gente morava em Marechal Hermes, praticamente perto da Portela, que fica ali entre Madureira e Oswaldo Cruz. Aquela região é dominada por portelense. É Oswaldo Cruz, Bento Ribeiro, Marechal, essa região é região da Portela.

O meu pai apareceu na Portela porque o meu tio desfilava lá, na Ala dos Impossíveis, onde o Candeia também desfilou. E o meu pai, como aprendeu a tocar cavaquinho, por causa do meu avô... Meu avô tocava aquele banjo tenor. Reza a lenda que meu vô não queria que meu pai saísse para tocar por aí, porque músico, naquela época, era tido como cachaceiro, essas coisas, e meu avô não queria que meu pai bebesse cachaça. Quando ele percebeu, meu pai já estava tocando, às escondidas, aí ele falou pro meu pai, com a voz grossa assim:

- Ah, você já tá tocando bem, agora vê se não vai beber, sair por aí bebendo cachaça, hein rapaz?

Foi tudo que ele fez. Tudo que ele fez.

E meu pai começou, a primeira escola em que ele desfilou foi Império Serrano, não sei como, mas ele já estava ligado no pessoal da música. E meu tio era quem desfilava na Portela. Então, por intermédio do meu tio, meu pai começou a aparecer na Portela, tinha irmão que tocava cavaquinho, e dali conheceu Casquinha, esse pessoal, Candeia, e daí foi ficando, ficando... E ficou. Quando foi ver, já era um coração portelense. Não é que ele fizesse parte da fundação da escola, não foi nada disso, ele apareceu na escola, como tantos outros também apareceram, e dali foi ficando.

Na época em que foi formada a Velha Guarda, em 1970, meu pai já desfilava na escola, então aquela formação, muitos bambas ali já poderiam ter integrado a Velha Guarda, mas nem todo mundo fazia parte daquele grupo de show. O Paulinho da Viola foi que montou mais ou menos aquele grupo, e convidou meu pai, porque o Jair do Cavaquinho, que era pra ser o cavaquinista da Velha Guarda, tinha outro 
grupo, outros compromissos. Ele tocava muito com Zé Keti, lá para baixo, então não tinha tanto aquele compromisso de estar ali, e o Paulinho da Viola convidou meu pai para fazer parte. Como já estava na Portela mesmo, foi ficando, e já tocava com Candeia... E fez parte desse seleto grupo de acompanhantes.

A velha guarda tem uma convivência de respeito... Eu fico vendo: a velha guarda, no geral, não é só a musical, são aqueles que trabalharam na escola, por isso são chamados de velha guarda. Vieram muito antes, trabalharam, foram diretores de harmonia, ou mestres-salas, ou da ala das baianas, esses todos antigos são chamados de velha guarda. São pessoas antigas dentro da Portela, por isso são chamados de velha guarda. Esses que são chamados de Velha Guarda musical, ou Velha Guarda show, além de trabalharem, tinham um outro trabalho, que eles compunham sambas, digamos assim, aqueles sambas desinteressados, sem aquela forçação que tem hoje em dia, da gravação, era um samba para ser cantado, ali dentro, no dia a dia, numa brincadeira, entendeu? E esses criaram, como eles chamam, samba de terreiro. Era o Seu Manacéa - o Monarco era o mais novo deles - Alvaiade, Mijinha, irmão do Manacéa, e tantos outros que também faziam parte daquele grupo ali, mas não se integraram ao grupo show... Chico Santana fazia parte, Alcides Malandro Histórico, que todo mundo hoje canta o samba dele aí:

Eu vivia

isolado do mundo...

Também era desse grupo e da formação da Portela, mas não fazia parte da Velha Guarda show. O que era mesmo que eu ia dizer?

Então esses aí, que trabalharam e ainda criaram coisas, eram chamados de Velha Guarda show, porque eles cantavam a criação deles, o Manacéa cantava Quantas Lágrimas era, muito bonito:

Ah, quantas lágrimas...

Não tinha coisa mais bonita. Então eles, além de trabalharem ali dentro, eles ainda criaram coisas. Agora, a outra velha guarda é o pessoal que trabalha mais, dentro da escola, tem uma função ali dentro. Eu posso dizer que hoje em dia eu estou comendo o filé mignon, porque os outros ralaram lá atrás. Antigamente, quase não tinha nenhum show da Velha Guarda, era um show por ano, e eles ralaram pra criar aquele nome, para agora a gente estar com o filé. Mas alguém tinha que fazer isso, e nada mais justo do que a gente também, que foi criado ali dentro, eu, Áurea, Mauro Diniz... A gente acompanhou a nossa vida toda a Velha Guarda da Portela. Então eu acho que ninguém ia dar mais valor do que a gente ali, que viu, e que considera isso a nossa raiz.

O Mauro Diniz pode fazer parte da Velha Guarda, ainda não está, mas ele sabe que é, ele já fez parte, uma época. Aí depois, ele tem os projetos dele, tem a vida dele, particular, o Mauro é um maestro, é compositor também, tem o disco dele, então não dá para ele sempre estar com a gente, mas sempre que pode, e sempre que a gente também precisa dele, ele está ali. O Mauro é um reserva de luxo, digamos assim, que não é reserva. A hora que ele quiser ser titular, ele é.

Hoje em dia, o que mais me deixa triste é saber que um dos nossos não está podendo mais trabalhar, não está podendo ir, ou então que a gente está perdendo, como perdemos Jair do Cavaquinho, perdemos Argemiro... Durante muito tempo na escola, não foram criados sucessores pra eles. Não apareceram, porque a geração deles era uma formação natural. Infelizmente, digamos assim, foram aparecendo 
todos numa mesma geração... Hoje em dia a gente não vê sucessores para eles, não tem. Quem tinha, a gente já aproveitou, foi o Edir, que agora também faleceu... Não tem craques, que nem eles, ali.

Agora, pode ser que esteja aparecendo aí uma nova geração, eu digo, essa nova geração da qual eu também faço parte, porque eu tenho 42 anos. Estou na Velha Guarda, mas eu sei que a minha geração não é essa, eu estou substituindo alguém, entendeu? Mas tem o Wanderley Monteiro, que está surgindo aí, é um bom compositor, um bom músico, pode ser, futuramente, uma boa aquisição para a Velha Guarda. No momento eu acho até que não, mas futuramente, tenho certeza que vai fazer parte, que é uma pessoa que vai saber respeitar aquilo ali.

Na Velha Guarda tem uma coisa, que é muito maior que a gente... Ali a gente não tem a vaidade de... Eu não tenho a vaidade de chegar ali, cantar sambas meus, mas tenho a responsabilidade de guardar os sambas daqueles antigos, que ficaram. Porque a nossa responsabilidade é mostrar a nossa cultura, aquilo ali é que eles mostraram antes, e aquilo não pode morrer. Eu acho o seguinte: quando a gente não tiver mais o que mostrar deles, aí é que a gente começa a mostrar nossa história, porque foram eles que fizeram isso aí, então a gente não pode deixar morrer aqueles sambas. Quando a gente não tiver mais o que mostrar deles - até paralelamente a gente pode ir também mostrando coisas nossas - mas a gente tem que mostrar essas coisas que ficaram lá para trás, que estão sendo esquecidas, esses verdadeiros sambas.

Infelizmente não tenho fita com meu pai tocando, porque as pessoas gravavam, mas eles levavam a fita. Meu pai ia lá, acompanhava. Eles gravavam, porque os interessados eram eles, era música deles para eles mostrarem. Era uma coisa natural, a gente não tinha esse pensamento, que hoje tem "poxa, se pudesse ter gravado isso...". Hoje em dia era uma riqueza, mas a gente na época não tinha esse pensamento que poderia acontecer com a música. Até então, o samba não era nem tão valorizado assim, né? A gente não sabia que... Hoje em dia tocam no rádio, essas músicas, como essa que a gente está ouvindo aí, isso aí tem época para acabar, são coisas que a gente sabe que não vai passar dois anos e a gente não vai cantar isso aí mais. Se a gente soubesse que essas coisas que a gente escutou iam durar, a gente ia guardar, muito mais.

Para fazer o repertório da Velha Guarda tem muitas coisas gravadas. A pessoa que mais lembra as coisas da Velha Guarda é o Monarco. O Monarco tem uma memória... Que é impressionante, ele sabe o ano que foi e tudo. Daqui a pouco ele força a cabeça dele aqui, lembra a música, lembra um pedaço, daqui a pouco ele vai lembrar a música toda. Esse documentário, $O$ mistério do samba, mostra isso, ele lembrando um samba do Manacéa, daqui a pouco ele lembra mais, daqui a pouco ele lembra o samba todo. Ele é impressionante, e coisas que ele ouviu, e que ele viu, naquela época, também não tinha onde guardar. O Manacéa, por exemplo, guardava música dos irmãos dele, para os irmãos não esquecerem, cantavam pra ele, que não tinha gravador, essas modernidades que a gente tem agora, né? A tecnologia nos ajudou muito nesse sentido, agora não tem como a gente deixar uma música perdida, não fica. Mas naquela época não tinha, então precisava da memória, o Monarco aí é... É o nosso guru, também porque ele era o mais novo deles. 
Eu gosto mais de fazer a música, mas a gente, quando compõe junto, acaba fazendo letra e música. A gente dá idéia daqui, com parceiros ou também sozinho, dependendo do sentimento que a gente tem, alegria ou outra coisa, a gente acaba fazendo os dois. Eu fui compondo mais música de rádio. Teve uma época em que eu acabei assinando contrato de exclusividade, então tinha que apresentar um trabalho, era muito mais cobrado, porque eu fiz um contrato com uma editora, então tinha que apresentar trabalhos para eles... Nesse contrato eu peguei um dinheiro adiantado, e eu tinha que pagar aquilo ali. Então nessa época, eu estava sempre compondo, sempre compondo. Vamos supor, em um dia, eu tinha que compor de manhã, de tarde e de noite, porque, também não vou dizer que era uma música que fosse guardar, não, era uma música passageira, porque eu era cobrado nisso, mas tinha muitas coisas ali, quando não era cobrado, que já fluíam bem melhor.

Hoje em dia as escolas de samba ficaram muito ligadas ao negócio do sambaenredo, as pessoas só se interessam em fazer o samba-enredo, por quê? Porque o samba-enredo dá aquele dinheiro, então o interesse ficou muito grande nisso aí. Tanto é que nem todo mundo que compõe samba-enredo, que tem o seu nome lá, nem todo mundo compõe... São seis, mas dois correm atrás da grana, dois fazem o samba, os outros são responsáveis pela torcida, entendeu? Então o samba-enredo é muito isso, já o samba de quadra não, você fazia um samba, tipo um samba exaltação, pra você cantar antes do desfile, antes do ensaio, era um samba mais, falando da escola, aquela alegria toda. O samba de terreiro é aquele samba livre, que você não estipula o tema, você pode falar da escola ou não, é um samba livre. E hoje em dia as escolas de samba não têm isso, é muito só ligado ao samba-enredo. As coisas só acontecem na escola de samba quando começa negócio de samba-enredo.

Agora está até mudando, por causa desse negócio das feijoadas. Até fomos nós que começamos com isso, e a feijoada da Portela foi justamente para isso, para a gente poder cantar os sambas de terreiro, para não ficar morto, e acabou que até esse processo as escolas de samba foram jogando de lado, e já estavam desaparecendo outras coisas, que eram típicas das nossas culturas. Nada contra, mas lá na nossa feijoada, nêgo estava cantando Rebolation. Pô, o quê que é o Rebolation pra nós? A nossa cultura, ali dentro, aí vai cantar a cultura do outro? Nada contra o Rebolation, eles têm o espaço deles, até se eles forem lá, à Portela, para a gente também vai ser um orgulho, eles cantando a música deles. A gente ali dentro do nosso terreiro, a nossa cultura, a nossa raiz, a gente não vai cantar Rebolation. Aí, agora, a gente teve uma reunião, já tivemos outra feijoada voltando àquela idéia antiga, que é a gente resgatar, porque as pessoas estão indo lá para isso, as pessoas querem ouvir essa cultura, querem ver isso aí. Isso das feijoadas começou em 2004, 2005, por aí.

As mulheres, historicamente, pelo que eu ouvi falar, é que eram responsáveis pelo samba pegar na escola. Quando alguém dessa época, antiga, ia apresentar um samba, e as mulheres estavam lá, se o samba caísse no gosto das mulheres, o samba estourava, arrebentava, mas se não caísse, o samba ficava pra lá. Então, as mulheres é que eram, digamos, as pastoras, eram responsáveis pelo samba pegar na escola. Se as mulheres cantassem o samba, aí o samba ia, se não... Não adiantava forçar que não pegava. Então, dentro da Velha Guarda também se criou isso, as mulheres eram, as pastoras, aquelas vozes femininas, que faziam o coro, essas coisas todas. Isso historicamente, mas agora eu já tenho outra visão: como elas também presenciaram 
muitas coisas, eu já vejo que elas também fazem parte dessa história, não só como divulgadoras do samba, mas elas presenciaram, elas sabem o que é, e sabem até o samba que não pegou, entendeu? Elas fazem parte dessa história, digamos assim.

Dentro da Velha Guarda principalmente, porque a gente não tem mais aqueles grandes compositores de antigamente, eles mesmos cantavam a música deles junto da Velha Guarda. Era bonito, principalmente pra mim, que era fã, ficar assistindo ali, vendo o Seu Manacéa cantar, Chico Santana, Alberto Lonato... E a gente não tem mais isso... E hoje em dia, na Velha Guarda da Portela, as coisas estão muito em cima do Monarco, e ele também já está com uma idade, já está cansado, até a voz dele, não dá para ele cantar tudo, então a gente tem que dividir, entre as pessoas que tem ali dentro, porque os que mais ficaram na Velha Guarda são músicos, compositores não tem mais. O Casquinha, que até pouco tempo estava com a gente, já está cansado, tem os problemas dele, de doença, não pode acompanhar a gente sempre. Para que as coisas, os shows, digamos assim, não fiquem muito em cima do Monarco, é preciso que as mulheres cantem também. Elas conhecem a história, conhecem os sambas, então as mulheres estão aparecendo mais, estão cantando mais, entendeu? Dentro da nossa Velha Guarda da Portela, esse está sendo o papel das mulheres.

Geralmente, o Monarco sugere o repertório e a gente escolhe junto. Eu, principalmente na parte musical, que é a parte em que eu me sinto mais responsável. Eu vejo com Monarco, de acordo com o show, o quê que é legal a gente cantar, o que o público vai curtir, porque tem música para tudo quanto é espaço. Tem sambas que é legal a gente cantar: Coração em Desalinho, que o Zeca Pagodinho gravou, do Monarco, que a gente sabe que o público vai participar, vai estourar; tem outros shows, mais intimistas, em teatro, por exemplo, aí a gente procura rebuscar algumas coisas do Paulo da Portela, Cidade mulher:

Cidade, quem te fala é um sambista...

A gente procura rebuscar certas coisas para também não ficarem sendo esquecidas lá atrás.

Ah, eu gosto de lembrar dos encontros da Velha Guarda, as reuniões, os ensaios. Eram muito legais, principalmente quando estava a maioria, eu era pequeno, e ia lá para Oswaldo Cruz, nos fundos da casa da Tia Doca. Ali eles se reuniam, acho que era domingo ou sábado à tarde, eu não lembro bem, mas estavam sempre lá cantando, ali estava a essência mesmo da Velha Guarda, a maioria deles estava vivo - Alvaiade, Seu Manacéa, Chico Santana - pra mim, eles, ali, eram... O topo de linha, sabe?

Então agora eu fico vendo, eu participava disso aí tudo e não sabia qual era o valor que tinha; já gostava, mas não sabia que isso ia ser a minha vida. É muito grande, poxa... Engraçado que dali, a Velha Guarda quando parou de ensaiar, ali acabou virando uma roda de samba que hoje em dia eles dizem que é o Pagode da Tia Doca, mas na época era o Terreirão da Tia Doca, eu lembro que tinha esse nome e meu pai também era sócio dela, nessa época.

Depois dos ensaios da Velha Guarda, acabou virando marca, então eles começaram a botar cerveja para vender, Tia Doca fazia, sopa de ervilha, negócios assim, e acabou virando roda de samba, então todo domingo, durante o final dos anos 1970, início dos 1980, ali lotava. Foi mais ou menos nessa época que surgiu o Fundo de Quintal, que o samba começou a aparecer mais, teve o primeiro grande 
estouro, assim. Zeca Pagodinho ia para lá, Jovelina Pérola Negra, mas tudo meio informal, não era nada marcado, eles iam lá porque gostavam e eles estavam começando. E dali começaram a surgir novos nomes, que hoje em dia estão aí, Zeca Pagodinho - grande Zeca - e outros nomes, e a gente acompanhou isso aí tudinho. Eu e Luizinho, que hoje em dia é quem faz o pagode da Tia Doca, um dos filhos dela... A gente ficava lá catando garrafa. Nossa função lá era catar garrafa, as garrafas ficavam jogadas no terreiro, aí a gente tinha que catar garrafa.

Ah, tem uma música, lá da Portela, que acho que marcou e marca até hoje, até que o filme, no Mistério do Samba tem essa música aí, e quando ela é cantada, ela é de uma energia, que eu não sei te dizer. Deixa eu lembrar o nome...

Quando vem rompendo o dia

eu me levanto, começo logo a cantar

Essa doce -

Doce melodia, o nome da música ${ }^{49}$.

Essa doce melodia...

E é uma coisa natural, essa música, a história dela, não foi feita para tocar no rádio, não foi feita para nada, mas é de uma energia tão grande... A gente, quando canta essa música lá, principalmente na Portelinha - e justamente no filme é lá -, onde estão todas as vitórias da Portela, todas as grandes vitórias da Portela foram ganhas ali naquela Portelinha... Então parece que todos os deuses da Portela estão ali naquele momento, todos os orixás, é de uma energia... Nossa, que eu nem sei falar, dá vontade de chorar, dá vontade de tudo, o corpo arrepia... Até hoje quando a gente canta essa música eu sinto isso. Eu não sei o que dizer, é uma grande música da Portela... E Quantas Lágrimas também. É outra que arrepia o corpo que a gente não sabe... Falando vêm lágrimas nos meus olhos, nossa. A gente não sabe dizer o quê que é.

Eu nasci em 1967 e a Portela mudou para o Portelão em 1971, 72, onde é até hoje, então eu já sou da época do Portelão. Hoje em dia, a Portelinha não tem grandes atividades, então as pessoas ficaram só ligadas, realmente, ao Portelão. Mas eu acho que, se o caminho da Portela, para ganhar um Carnaval, for mudar para a Portelinha, acho que tem que mudar, porque ali tem muito mais chão, a energia é outra. Não sei se é a cabeça de dirigente, sei lá. Sei que a Portelinha tem uma energia natural, sei lá o quê que é.

\footnotetext{
${ }^{49}$ Composição de Bubú da Portela e Jamelão.
} 
Tia Surica durante apresentação da Velha Guarda da Portela no Portelão. Acervo pessoal da autora, dez. 2010.

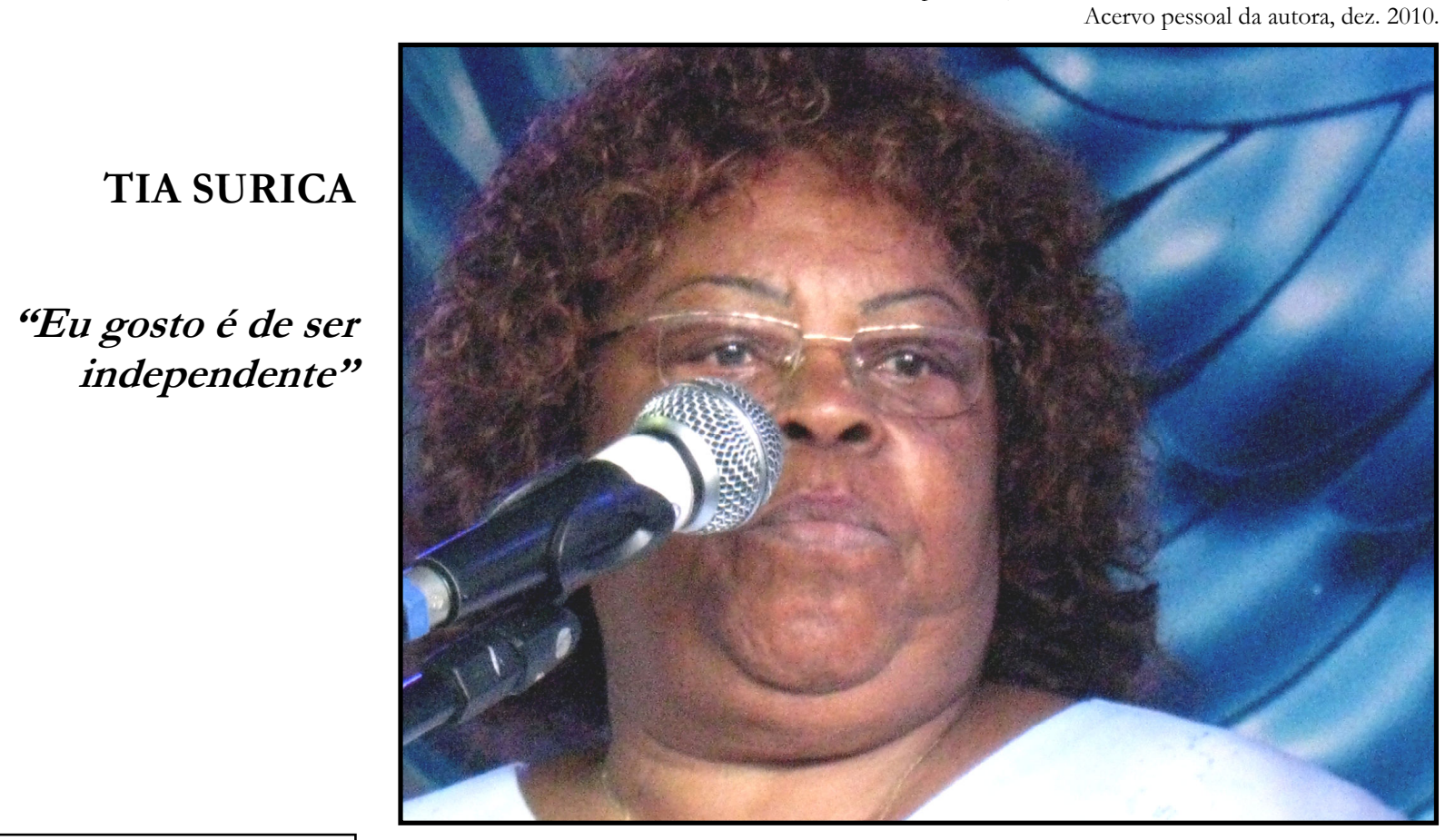

Lugares de Tia Surica:

1. Madureira (Rua Iguaçu)

2. Madureira (Rua Firmino Fragoso)

3. Quintino Bocaiúva

4. Inhaúma

5. São João de Meriti

6. Madureira

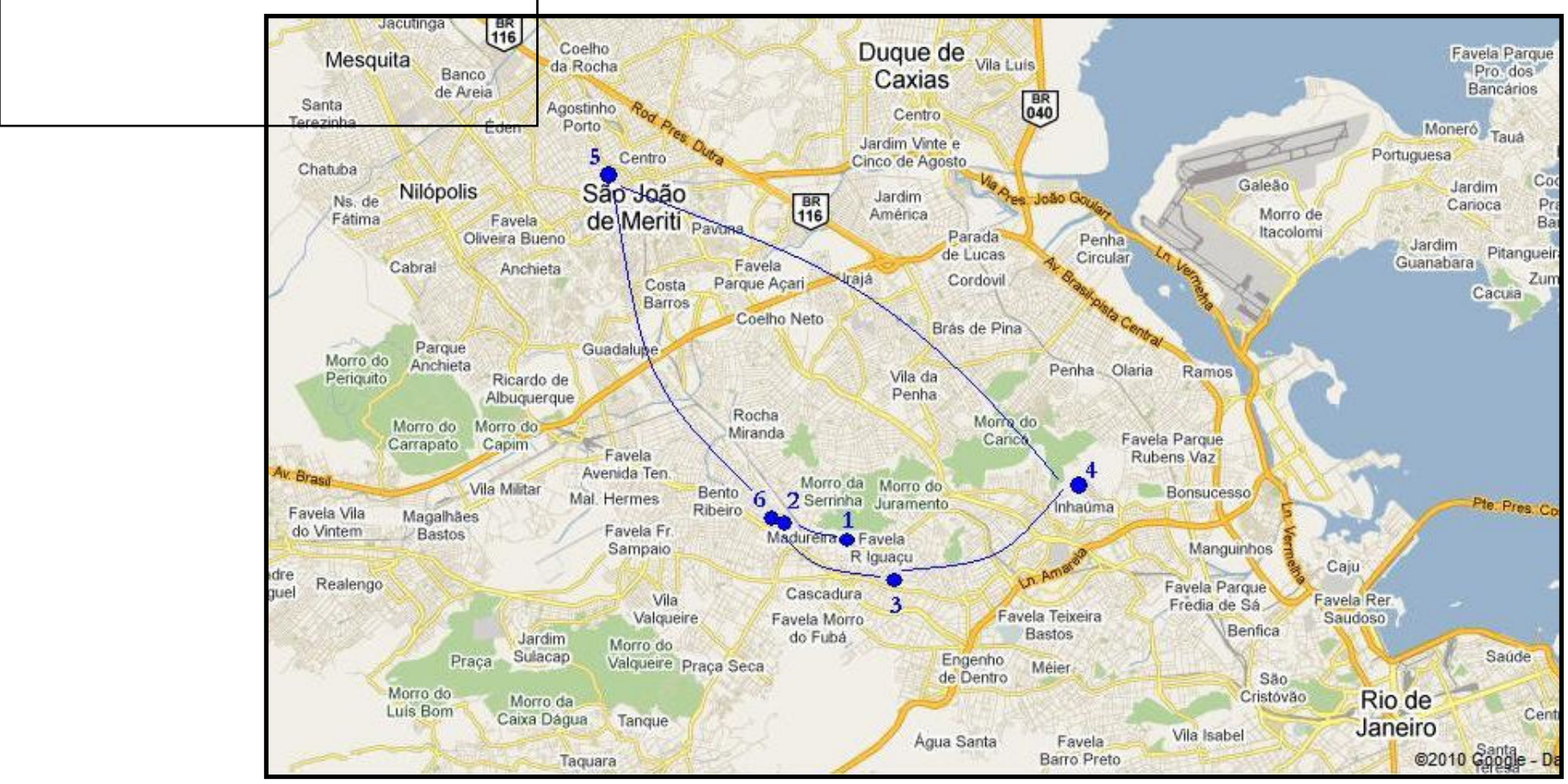


Meu nome é Iranette Ferreira Barcellos. Minha infância foi um pouco atribulada, mas graças a Deus eu consegui superar. Eu perdi meu pai criança, perdi minha mãe também criança... Meu pai morreu, eu estava com 12 anos; quando minha mãe morreu, eu estava com 7 anos. E eles é que me levaram pro samba. Comecei a sair na Portela com 4 anos, e é onde eu estou até hoje. Fui carregada por eles; eu não tinha noção naquela época. Eles faleceram e eu dei continuidade, é na Portela que eu estou até hoje.

Já saí na ala do coro, saí de baiana, saí em ala, fui intérprete, em 1966, do samba do Paulinho da Viola, Memórias de um sargento de milícias... Foi o primeiro e último samba-enredo dele, e eu tive a honra e o prazer de ser intérprete. E em 1980 eu me integrei na Velha Guarda.

Devo muito à Velha Guarda da Portela, e ao nosso saudoso Manacéa, que foi quem me encaminhou para a Velha Guarda. Abriram-se as portas, hoje eu tenho um disco gravado, gravo com vários artistas, e a Velha Guarda pra mim é tudo, sabe? Porque eu faço show independente, mas procuro conciliar pra não deixar de participar dos shows da Velha Guarda. Tudo eu devo à Velha Guarda da Portela.

A lembrança da minha infância foi como eu digo. O meu episódio mesmo, principal, foi quando eu fui convidada pra ser a intérprete do samba do Paulinho da Viola. Isso aí foi uma coisa marcante da minha vida, eu estava com vinte e poucos anos. Então ali, também, eu acho que eles viram - modéstia à parte - o meu talento, e eu fui caminhando.

Fui criada por meus avós, que me deram uma boa formação. Sabe que o samba naquela época era muito discriminado, e eu fui uma delas, eu fui muito discriminada por sair em escola de samba. Hoje em dia todo mundo está dentro do samba, né? Aí, é aquele negócio, meus...

Ih, meu Deus do céu, me deu um branco. É porque quando eu falo nessas coisas me dá muita emoção, sabe? O samba perdeu um pouco a sua essência. Porque naquela época, o samba era uma família. Inclusive o falecido Natal, ele tinha um carinho muito grande, se preocupava com as crianças, e tudo. Hoje em dia você não vê mais isso. E não podemos, também, esquecer do nosso saudoso Paulo da Portela, que foi o fundador da Portela. Hoje em dia, essa disciplina que a Velha Guarda tem, isso tudo nós agradecemos ao nosso professor, Paulo Benjamin de Oliveira.

Eu nasci aqui em Madureira, depois saí, fiquei uns tempos fora, mas voltei. Madureira é um reduto... Você sabe que a nossa vida tem altos e baixos, não é? Depois que meus avós faleceram, eu fui morar com irmã, e tudo... Fui morar em Quintino, morei em Inhaúma com outra irmã também, depois eu resolvi fazer minha independência e, graças a Deus, sempre com a minha cabeça erguida. Cheguei aonde eu cheguei por causa da minha personalidade, e de uma coisa que meus avós me deram: uma boa formação moral.

Eu fui trabalhar depois que meus avós morreram. Nunca trabalhei antes disso, que meus avós nunca deixaram. Eu acho que isso foi um erro muito grande, sabe? Você tem que começar a ser independente, saber o que é a vida. Eu estava com 30 e poucos anos, então é que eu vim ver o outro lado da moeda. Aí fui, aos trancos e barrancos, daqui, dali, mas consegui superar isso tudo. Trabalhei na Gillette, trabalhei na GE, fui promotora de vendas, já botei barraca na porta do Portelão para 
sobreviver, isso tudo. E tenho um orgulho muito grande de dizer que eu já ralei muito. Mas Deus olhou pra baixo, botou a mão em cima de mim, e eu, graças a Deus, agora, estou tendo uma vida tranqüila.

Sou muito religiosa. Porque, se não fosse aquele lá de cima... Triste da gente se não fosse Deus, e acima dele não tem ninguém. Não freqüento igreja... Eu sou espírita, não sou fervorosa. Mas agora, eu acendo minha velinha, quando eu vou fazer meus shows, faço meu sinal da cruz, rezo, e - pá - ataco no palco.

A partir daquele episódio, em 1966, comecei a fazer coro no disco do Zeca Pagodinho, do Paulinho da Viola, da Dona Ivone Lara, da Alcione, da Beth Carvalho, e assim sucessivamente. Aí um amigo que eu tenho, Paulinho Itacolomy, junto com o falecido Duarte, resolveram fazer o meu CD. Só que não deu certo, sabe? Tive uma decepção muito grande... Depois Paulão 7 Cordas e Ruy Quaresma trabalharam no meu disco, que saiu pela Fina Flor. Aí, em 2003 ou 2004, gravei meu CD. Ficou um disco muito bom, e agora estou me preparando, esperando só uma coisa aí, para fazer meu segundo CD, e vou conseguir, se Deus quiser, e Ele há de querer.

Olha, pra fazer parte da Velha Guarda da Portela, é aquele negócio, é a postura que o Paulo deixou. Você tem que ter uma história, você tem que ter um passado, tem que ter um passado pela escola. É conforme Monarco fala: para vestir aquele fardão, você tem que ter um passado. E eu fui cria da escola, não é?

O que mais me dá satisfação é o dia de carnaval, o desfile. Quando eu vejo aquela minha águia entrando na Marquês de Sapucaí, eu esqueço tudo. Até hoje. Aquela águia pra mim é tudo, aquela águia altaneira. Infelizmente o samba mudou muito, mas mesmo com isso aí quero estar presente.

Isso de a velha guarda ter passado a sair atrás, é uma coisa que... O negócio é a velha guarda estar presente, ou na frente, ou atrás, do lado, o importante é eles não esquecerem a espinha dorsal que é a velha guarda da Portela, de qualquer escola. Mas eu falo da minha escola. A espinha dorsal de qualquer escola é a velha guarda, então, não pode excluir a velha guarda. E o relacionamento da velha guarda com a escola é igual até hoje. Nós somos independentes da escola, então nada nos atinge.

Para definir quem vem depois, é aquele negócio, a gente tem uma reunião, pra ver se a pessoa...

- Fulano, quê que você acha? Você acha que fulano tem condições de participar da Velha Guarda show?

Porque velha guarda só existe uma, só que o Paulinho destacou a Velha Guarda show, com os compositores da Portela, mais antigos, então ele montou esse grupo. Mas a velha guarda é uma só, também um palco não comporta todo mundo. Nós somos destacados porque nós temos compositores, nós gravamos... E é isso. No palco, em qualquer lugar, nós representamos a velha guarda. A Velha Guarda já é conhecida até internacionalmente.

Tem um grupo, esse que eu estou dizendo, é o grupo da Velha Guarda show. No disco Passado de Glória as coristas eram a Tia Vicentina, a Tia Lourdes e a Tia Iara. Depois era eu, Doca e Eunice. Eunice se afastou porque está doentinha, a Doca faleceu, então agora tem a Áurea, a Neide e eu. Tem o Monarco, o Guaracy, a percussão, e os grupos de corda.

Áurea já está há quase 10 anos. Eunice ficou doente e Monarco, conversando comigo: 
- Surica, nós temos que arrumar uma pessoa pra botar, que a Eunice não tá tendo condições.

E eu me lembrei dela, que ela é filha do Manacéa, então é a continuidade. Ela entrou e está até hoje.

Do livro de ouro não lembro, não, porque foi na época do Natal que faziam. O Pedro e o Jibóia é que percorriam as lojas, pra assinar, pra botar o carnaval na rua, mas o samba evoluiu muito, não é? Era a época de dinheiro daqui e dali, e o samba era muito melhor. O pessoal tinha mais amor ao samba, eles vestiam a camisa, hoje em dia não, todo mundo agora é sambista. Eu sei que não sou como todo mundo, eu sei, porque eu sou sambista, visto a camisa, mas agora não, todo mundo agora sai em escola de samba. Na época era bem discriminado. Agora todo mundo sai.

Depois que eu fiz minha independência, fui morar sozinha, e hoje eu moro com a minha irmã. Mas minha casa está sempre cheia, minhas patroas estão sempre aqui comigo, com negócio de feijoada... Ontem mesmo teve. Sábado que vem também tem outra pra fazer, e tem também a roda, a feijoada do Teatro Rival, que é todo último sábado de cada mês.

Ah, porque o samba, sem uma comida e sem uma bebida, e uma roda de samba bem legal, não é samba, não é?

Eu já dei muita festa aqui, muita mesmo. Quando eu fiz 50 anos, um amigo que eu tenho chamado Fernando começou com isso, tinha uma prancheta, com o pessoal que vinha para participar, enfim, era uma coisa muito engraçada. De lá pra cá, esse quintal aqui, você não andava, meu aniversário, aniversário dele, audição de disco de amigos meus:

- Surica, posso fazer lá?

- Pode!

O lançamento do Tudo Azul, também, foi uma feijoada aqui, teve um evento do Paulinho da Viola, foi um peixe, também aqui... Eu sou festeira, eu gosto. É que agora, a idade vai chegando, você já vai se acomodando... E é muito puxado, você trabalha antes, durante e depois. Com a idade, você já vai ficando meio caidinha... Mas eu gosto. E graças a Deus, tem gente ajudando!

É aquele negócio: já trabalhei muito, agora, graças a Deus, eu nem administro, porque elas não são crianças, elas sabem o que elas estão fazendo...

- Surica, aqui, o quê que cê acha?

Eu digo:

- Vocês sabem, eu não quero saber não, o que vocês fizerem tá bom.

Porque a pior coisa que tem é você estar fazendo uma coisa e chegar:

- Ah, isso aqui num tá bom não, hein?

Se é assim, eu vou fazer. Aí não, elas fazem, tem dado certo, tem a minha prima, a outra irmã dela, também minha prima, tem a minha irmã, e tem umas três ou quatro... Eu sei que lá no Rival é um total de 10 ou 11 pessoas. Não só fazendo a feijoada, também tem que servir, tem que repor... Mas eu já levo pronta daqui. Aí tem a Kombi que leva, são duas Kombis.

A feijoada de sábado começa a ser preparada na quinta-feira, que a gente tem que tirar, limpar os salgados, tem que tirar o sal. O problema todo da feijoada é o sal. Mas graças a Deus, é só vitória. 
A minha vida... Acho graça que eu perdi um casamento por causa de Portela. Eu era noiva, foi nesse ano, em 1966, eu puxando o samba com o Maninho e o falecido Catoni. Só que eu esqueci que naquela época já existia televisão. Quando meu ex-noivo me viu na televisão, ele disse:

- Olha mamãe, a dama com os dois valetes ao lado!

Veio e desmanchou o casamento. Mas Deus sabe o que faz.

E graças a Deus eu nunca me casei. Fui noiva duas vezes, mas não casei. Não tenho arrependimento. Eu tenho minha vida livre, não tem ninguém que diga assim

- Você não vai ali.

Não. Eu sou independente. Minha vida é tão boa, minha vida é tão preciosa, não é? 
Áurea Maria durante apresentação da Velha Guarda da Portela no Portelão. Acervo pessoal da autora, dez. 2010.

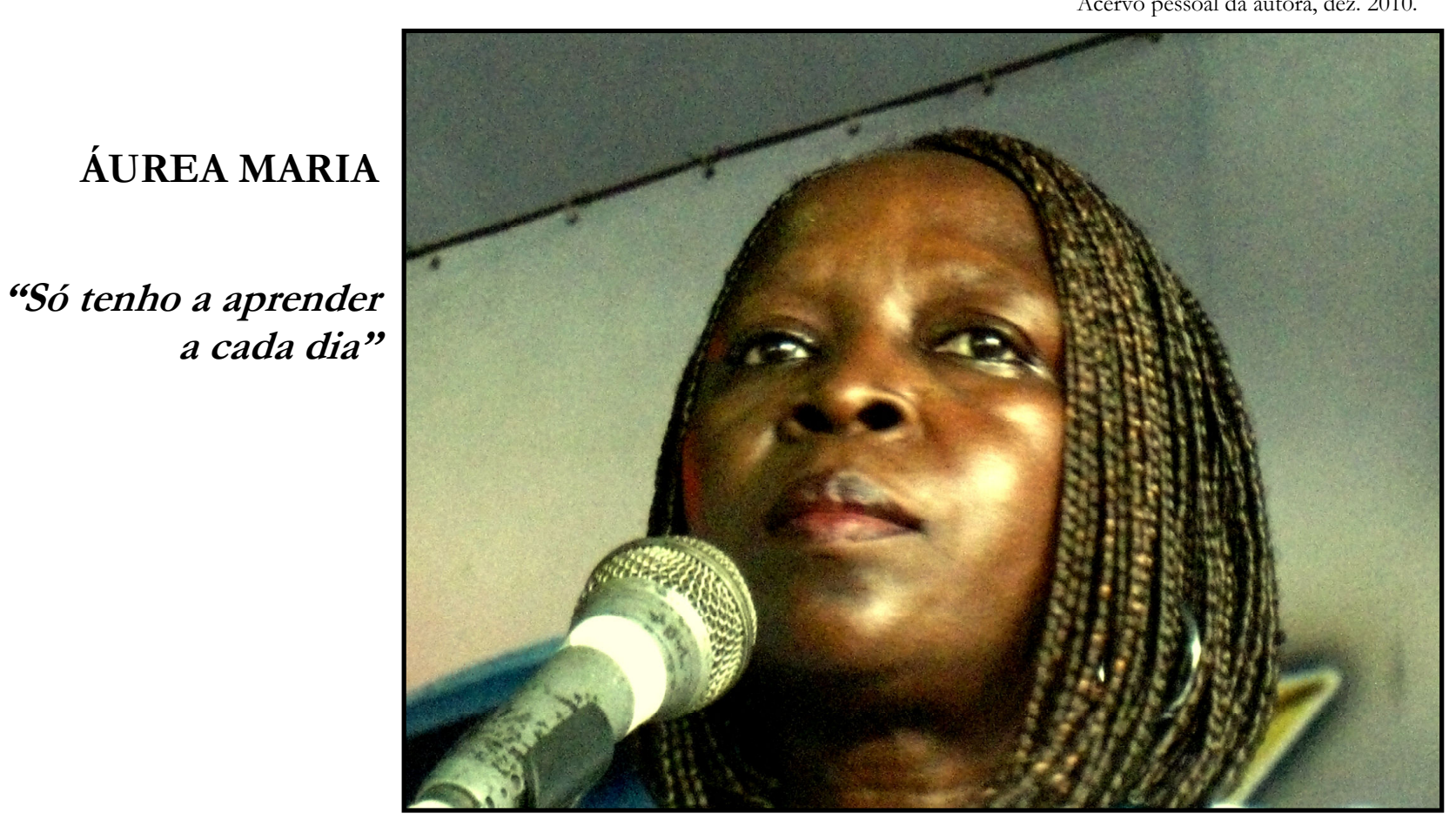

Lugares de Áurea Maria:

1. Madureira

2. Rocha Miranda

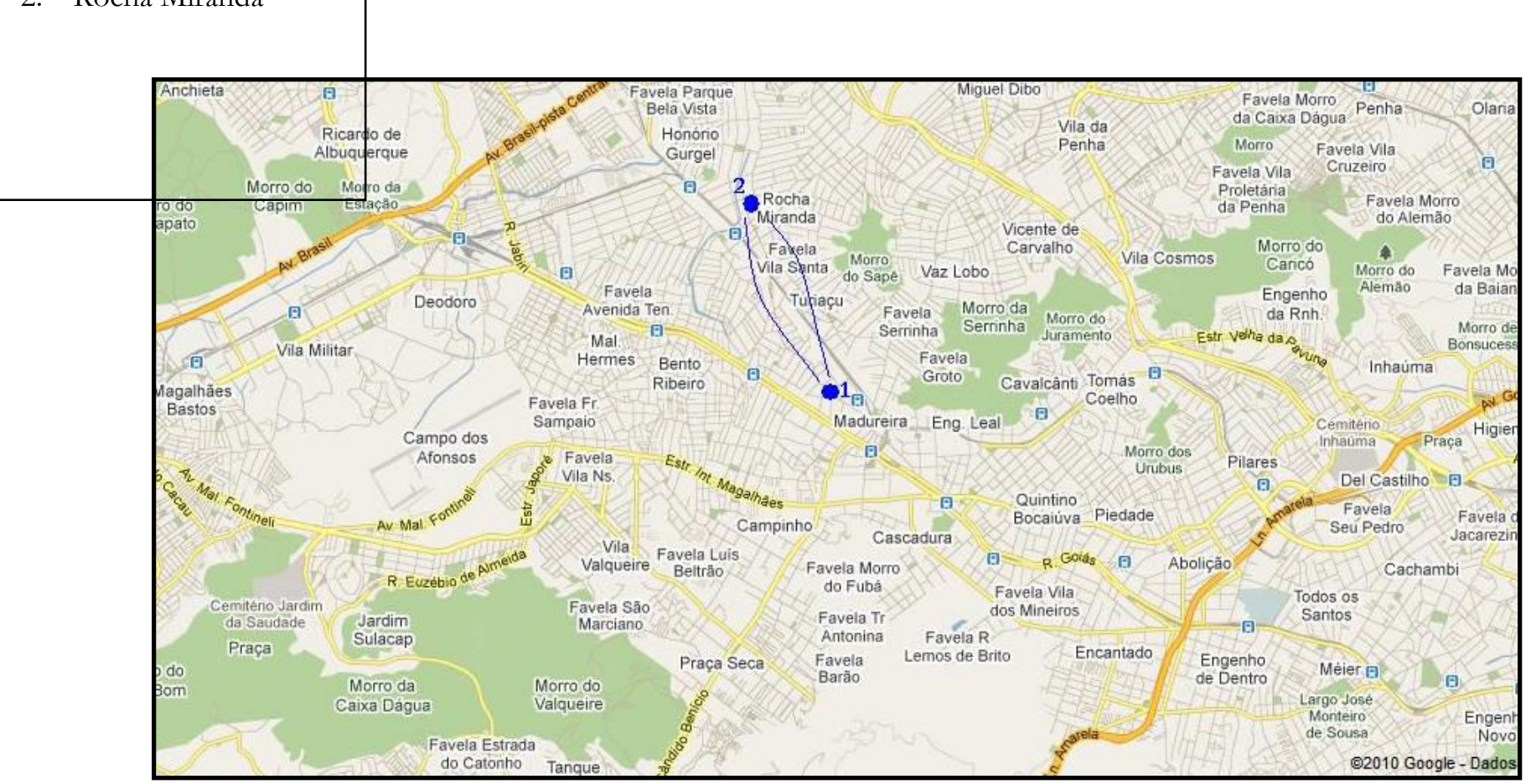


Eu nasci entre os bairros de Oswaldo Cruz e Madureira, onde estou até hoje. Sempre convivi com meus pais, na minha infância, adolescência... Depois de adulta, logicamente, me casei. Minha infância é sem grandes coisas surpreendentes. Eu estudava e sempre ajudava minha mãe. Porque a vida era difícil, então criança tem que ajudar mesmo. Tenho duas irmãs, que também colaboravam. Brincávamos, não tinha nada, assim, de diferente da infância de outras crianças.

Com bastante dificuldade, talvez isso seja um traço diferencial. Uma infância com bastante dificuldade para estudar, e depois, no decorrer da vida, também. Depois que nós saímos da escola pública, que terminamos o ensino primário, nós continuamos a estudar, que era a nossa vontade e a vontade dos nossos pais.

Comecei a trabalhar pra me auto-sustentar, fiz primeiramente o curso de auxiliar de enfermagem e depois a faculdade de Serviço Social, na Universidade Gama Filho. Sempre trabalhei na área da saúde, em unidade federal, e me aposentei como assistente social. Atualmente, vivo para a Velha Guarda, gosto demais. Vivo pra cantar.

Meu pai realmente fazia isso que eu comentei no filme ( $O$ mistério do samba), porque na época não tinha gravador, não tinha essa tecnologia avançada. E quando ele fazia música, para não esquecer, ele nos chamava:

- Olha, guarda essa música pra mim, não esquece!

Cantava e fazia a gente repetir, para fixar. Quando ele precisasse, já tinha reserva na memória. Algumas a gente lembra, outras eu já esqueci.

A minha casa sempre foi uma casa festiva. Meu avô participava de um grupo que tocava chorinho, e nos finais de semana ele reunia esse grupo em casa. Aos domingos, eu já amanhecia ao som do bandolim. E depois, papai também, envolvido com a Portela, continuou, então sempre tinha movimento de música lá em casa, e eu sempre ficava muito atenta a tudo. Atenta ao chorinho, atenta ao samba, e fui me envolvendo, não tinha como deixar de me envolver. E depois comecei a acompanhar meu pai, ficar mais perto dele. Até compus uma música com ele, Volta meu amor. Tem outras, mas essa chegou a ser gravada.

Não foram muitas, porque não deu tempo. Às vezes eu o chamava:

- Papai, fiz uma música!

- Ah, me deixa descansar, depois eu vejo.

E assim ia, e às vezes, quando ele pegava, eu já tinha muitas, não dava pra ver tudo. Mas depois ele adoeceu, não deu tempo de compor muito mais. Mas o que ficou, o que foi feito, foi muito bom, muito bom. Talvez se tivéssemos feito muitas, não teria o mesmo sabor quanto essas, que foram tão poucas, mas com uma grandiosidade, pra mim... Enfim, assim foi, me envolvi na música, desde pequena, depois me aproximei muito mais de papai, e após seu falecimento, veio o convite para eu integrar a Velha Guarda.

Foi através da Surica, porque Seu Monarco tinha pedido a ela pra providenciar uma pessoa pra substituir Dona Eunice, que na época estava afastada para cuidar da saúde. E a Surica foi procurando, e ela também foi uma pessoa sempre muito próxima de nós. Surica praticamente foi criada por minha mãe, conviveu muito tempo lá em casa. E nós cantávamos juntas, ela cantava samba-enredo com meu pai. E um dia cheguei na casa dela, junto com minha mãe, e ela disse: 
- Ah, como não lembrei? Tinha que ser você!

Fiquei assustada:

- Mas, tinha que ser eu, o quê?

- Ah, é você, é você!

- Mas o quê?

Então ela disse:

- Monarco me disse pra procurar uma pessoa para integrar temporariamente a Velha Guarda, e tem que ser você.

Eu disse:

- Ah, eu não quero, é muita responsabilidade!

Ela repetiu:

- Você vai, não pode dizer não!

Eu pedi um tempo, conversei com as pessoas, todos me aconselharam a aceitar:

- Assim você ajuda a manter vivo o nome do seu pai.

Eu disse:

- Mas eu não substituo meu pai.

Eu falava para as pessoas.

- Não, mas não é assim... Toda vez que mencionarem o nome do seu pai, você vai estar ali pra representá-lo..

Enfim, me convenceram. Assim eu comecei com a Velha Guarda temporariamente... Há mais de dez anos. Quando Dona Eunice voltou, eles não me deixaram sair. E fiquei até hoje, com muito orgulho, porque participar da Velha Guarda da Portela é um orgulho muito grande pra mim. Só tenho a aprender a cada dia.

O repertório dos shows cabe mais ao Seu Monarco, ao Paulinho Figueiredo, que é o empresário, e às vezes ao Serginho. São eles que escolhem, mas nenhuma das músicas é estranha para nós. Desde pequenininha eu as conheço.

Ainda não ajudei a recuperar o repertório, porque na época que foram selecionadas as músicas pra gravar o CD Tudo Azul, eu não fui para a casa da Marisa Monte, onde a seleção foi feita. Mas quando eu vi o filme, o que eles falavam, lógico que eu lembrava das músicas. Porque, como eu disse no filme, nós cantávamos os sambas da Portela como brincadeira de roda, como cantiga de roda, estava muito presente e muito fixo. Às vezes começamos a relembrar... Seu Monarco até quer fazer uma reunião para buscarmos as "músicas do baú", como ele fala:

- Vamos buscar, que a Velha Guarda tem um baú muito rico, vamos nos unir pra lembrar.

Tenho certeza que a mente vai funcionar, e eu vou lembrar muito. Vai ser legal, muito bom.

É um pouco temerosa a idéia da continuidade, entende, mas ninguém é insubstituível. Eu acredito que a Velha Guarda, na sua trajetória, passou e passa uma mensagem muito forte, cultiva a raiz do samba. Quem vier, vem com essa intenção, de manter e dar continuidade a todo esse trabalho, que é feito. Eu acredito que ela vai se manter.

Sempre morei na antiga Rua Dutra e Melo, essa é uma depois da rua do Portelão, a Rua Clara Nunes. E atualmente ela tem o nome do meu pai, Rua 
Compositor Manacéa. Onde eu sempre morei, nasci e fui criada. Me casei e fui morar em outro bairro próximo, que é Rocha Miranda, mas eu quase não fico em minha casa, eu fico mais em Madureira. Ainda não cortei o cordão umbilical.

Eu tenho intenção agora de começar a explorar esse lado de compositora, vamos ver se ano que vem... Não mostro para ninguém as minhas composições, praticamente não. Depois que papai faleceu, eu também deixei um pouco, esse lado ficou bem adormecido. A lembrança era muito presente, muito forte. Passado algum tempo as pessoas começaram a perguntar:

- Você não compõe mais?

- Você não tem mais contato com a música?

Eu falei:

- Vou começar a rever.

E comecei a buscar. E agora, estou me interessando em ativar essa questão de cantar. Faço letra e música. Graças a Deus. Infelizmente não toco nenhum instrumento, até tentei, mas não consegui. Talvez, quem sabe? Num próximo momento, quem sabe eu aprendo a tocar cavaquinho, que eu gosto. Vamos ver.

Sempre desfilei na Portela. Todos os anos. Desde pequena, eu ia para a quadra com minha mãe, eu era bem pequena, tinha 6 anos. Eu me lembro de ter 6 anos, quando comecei a freqüentar a Portelinha...

Vi a Velha Guarda nascer, graças a Deus. Conheci todos, lembro. Inclusive meus tios, o irmão do meu pai e um irmão da minha mãe, Lincoln, foi um dos parceiros de Paulo da Portela, participava da velha guarda. Do início, da primeira formação, meus tios participavam, então a lembrança é bem presente. 
Wilson das Neves em sua residência. Acervo pessoal da autora, jan. 2011.

WILSON DAS NEVES

"Você pode melhorar aquilo que está fazendo sem deturpar, como diz

o Paulinho da Viola não me mexe no samba tanto assim, né?"

Lugares de Wilson das Neves:

1. Glória

2. São Cristóvão

3. Catumbi

4. São Cristóvão

5. Benfica

6. Copacabana

7. Botafogo

8. Jardim Guanabara

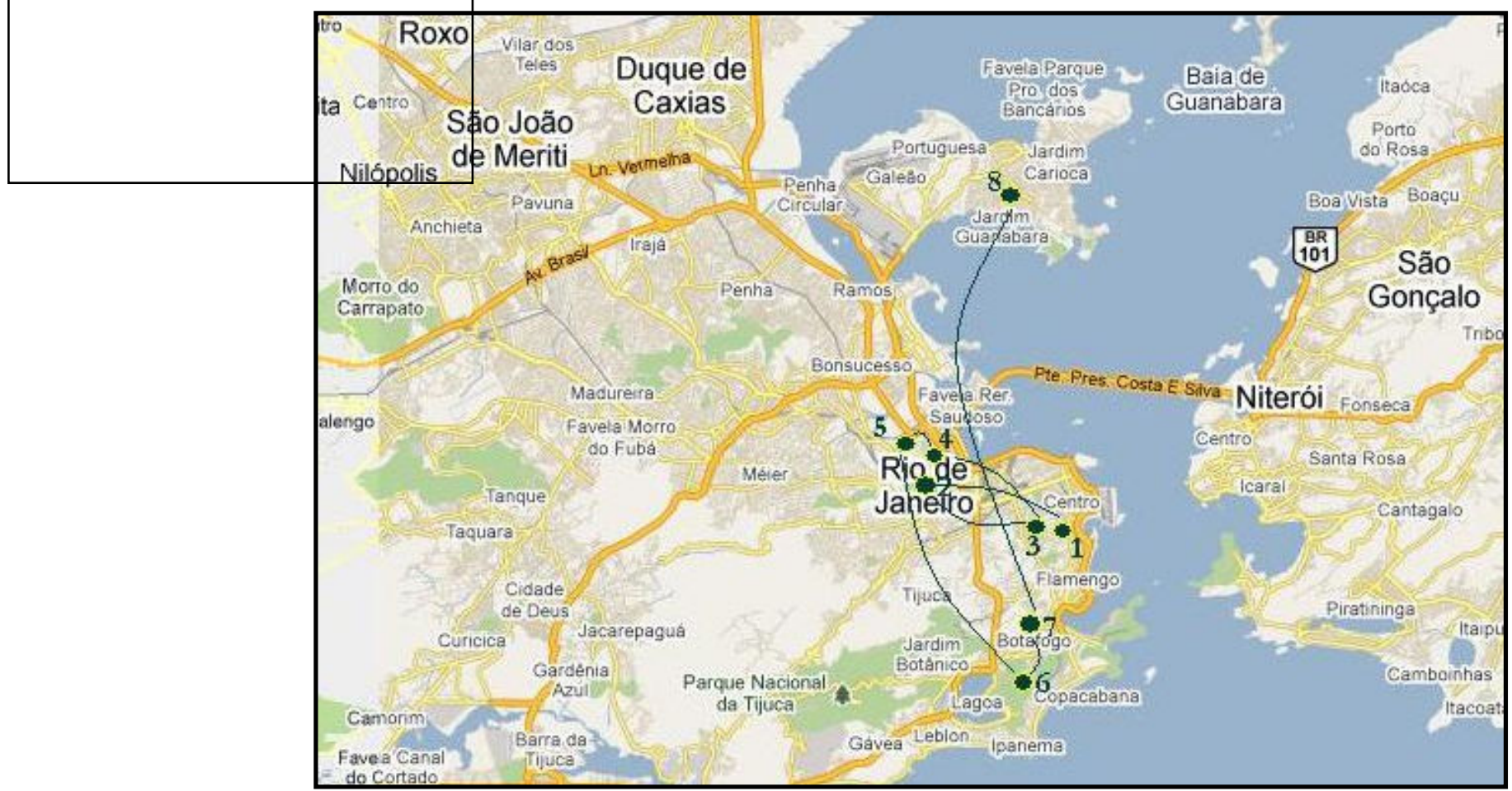


A escola de samba, para mim, perdeu a sua finalidade principal, que é fazer o quê? Formar sambista. Hoje se "importa": tem uma porta-bandeira boa lá na Unidos Não Sei De Onde, mandam buscar. Não tem mais aquele amor. Outro dia eu estava conversando com Nelson Sargento, que é meu parceiro, da Mangueira, que dizia que antigamente era feito com amor, hoje é feito com dinheiro. Então a coisa mudou muito, sabe? Se perdeu aquele prazer, aquela honra de carregar a bandeira da sua escola. Culpado disso é quem paga, não é? Quem começou com isso de importar foi o Natal da Portela. Ele levou uns dois mestres-salas do Império, contratava, pagava, e isso foi crescendo, foi mudando e as escolas todas começaram a fazer a mesma coisa para poder concorrer. Então esse amor pela escola morreu, só existe na velha guarda, na bateria e alguns compositores.

Não tem duas escolas, não, eles continuam lá, gostando da escola como antes. Os outros, que ganham dinheiro, também gostam, mas são profissionais. Todo mundo ganha dinheiro em escola de samba, menos o sambista, que paga para sair. Eu acho tudo errado, mas voltar atrás, não volta. Isso até acabar, porque daqui a pouco vai virar outra coisa. Vão botar efeitos não sei de quê e vai mudando, vai mudando, deixa de ser escola de samba pra ser show bizz.

Hoje só vem alegoria, cadê o povo? Aliás, um samba do Império, o Bumbum paticumbum, diz "escondendo gente bamba, que covardia!", quer dizer, o sambista ninguém vê! Vê carro alegórico, do tamanho de um prédio, com as mulheres lindas lá em cima, e daí? E cadê o samba? E cadê o passista? Não tem. Coisas importantes da escola a televisão não mostra, só mostra o que interessa a ela, o artista da novela, pra promover a novela; não mostra mestre-sala e porta-bandeira, a dança deles, o momento mais importante do desfile. E a bateria é o que segura, não tem baile sem orquestra, tem? Se a bateria parar, vira o quê? Mas eles dão valor à rainha de bateria. Será que lá no morro não tem uma crioula que era só dar um banho de loja nela e botar ela lá? Na hora que ela pode ser rainha, ela vira escrava de novo.

E não vale nada aquilo, mas as rainhas pagam pra sair ali. Elas se vestem e pagam pra sair, porque dá ibope, capa de revista. Ninguém presta atenção na bateria, ficam atrás da rainha de bateria, que às vezes até atrapalha. Você quer andar com a bateria e não pode, há milhões de câmeras, elas se exibindo... E a bateria, que é o que conta ponto? Atrapalha. Ninguém reclama porque quem manda é o Seu Fulano, e fica nisso.

Isso que está aí não é mais escola de samba. É tudo igual, passa correndo, parecendo que está tocando marcha, não se entende nada. Ninguém canta o samba do ano passado. Ninguém lembra mais, porque não tem conteúdo, não tem nada. É marchinha! Primeira, segunda e acabou, vem o refrão... É fácil, todo mundo aprende, mas não guarda. Aprende na hora, pra cantar, mas na hora de lembrar, vai cantar o quê? O de 1950. Escola de samba desfila feito boi: toc-toc-toc-toc-toc, e vamo, vamo, vamo, como relógio, as escolas não evoluem. Na evolução, as alas entravam umas nas outras, isso é que era evolução, e não tem mais. Então pra mim acabou, ou melhor, virou outra coisa. É tudo muito igual, a única coisa que muda de uma escola para outra é a cor da bandeira. Antigamente se uma escola era verde e branco, tudo era verde e branco. Um tom de verde mais claro, mais escuro, mas era tudo verde e 
branco. Hoje é um arco-íris... São todas iguais, não tem diferença. A única diferença é na cor da bandeira e na cor da escola.

Eles estão modernizando, mas modernizar não é deturpar, não é? Você pode melhorar aquilo que está fazendo sem deturpar, como diz o Paulinho da Viola - não me mexe no samba tanto assim, né? Isso já se vem falando, mas ninguém presta atenção. Cantam o samba e não sabem o que é que o Paulinho está dizendo: “eu aceito o argumento, mas...". É o que eu estou dizendo, eu aceito, mas não precisa ser radicalmente! Por exemplo, não pode ter instrumento eletrônico, é proibido, mas daqui a pouco vai ter uma orquestra lá. Se não botar funk, DJ, bota a bateria em cima de um carro, que é pra passar mais depressa, porque as escolas de samba estão sendo dirigidas por quem não conhece de samba. Conhece de administração e dinheiro, mas quem põe dinheiro quer mandar, quer ser o dono do negócio. Só que isso é de uma ignorância, porque para ser um bom administrador eu tenho que me cercar de gente em quem eu confie, que eu saiba que tem competência pra resolver o que eu não sei fazer. O pessoal acha que sabe tudo, é presidente, é carnavalesco, é compositor, junta o samba de um com o do outro ${ }^{50}$... Eu acho que é errado isso. Eu tenho uma concepção pra fazer um samba e você tem outra, quem é que vai julgar e aonde é que vai juntar? Mas os compositores não reagem nada, por causa do dinheiro.

O samba tem dez compositores, mas precisa de dez pra fazer um samba? Não precisa. Então o que você subentende ali? Um paga o prospecto, o outro paga a cerveja, o outro paga a alegoria, outro paga o ônibus pra levar a torcida e assim vai, e todos fizeram o samba. Aí tem dez no samba; quando ganham, aquele dinheiro é dividido pelos dez. Antigamente não era assim - eu tenho quarenta anos de Império Serrano, sei do que estou falando. A gente ia ao museu, à biblioteca, eles davam um tema e a gente ia lá, estudava.... Hoje tem uma fôrma, joga ali e sai, fica tudo igual.

Mas não vai voltar atrás, seria como querer acabar com o computador! É o que eu digo, as coisas são mal usadas. Você pode melhorar sem deturpar nada. Só que aqui tem um modismo. Alguém diz "é isso", e tudo é isso. Conjunto de pagode, por exemplo, tinha quinhentos: pirraça, com graça, sem graça, desgraça, sem desgraça, com preconceito, sem preconceito - quinhentos. Perdeu porque era tudo igual, não tinha diferença, a gente escutava:

- Quem é que está cantando?

- Não sei, conheço as músicas. Pra mim é o pirraça.

- Não, é o desgraça.

O Império tem uma gomazinha que agarra a gente, quando você vê já está lá. Digo sempre que nasci imperiano, apesar de o Império ser mais novo que eu: em 1947, quando foi fundado, eu tinha mais ou menos 8 anos, mas não era muito ligado. Minha mãe se tornou baiana da escola, então aquilo veio, só se falava em Império Serrano e acabei gostando, como clube de futebol. Foi a primeira escola de samba em

\footnotetext{
${ }^{50}$ Por exemplo, Lopes (1981, pp. 42-45) e Mussa \& Simas (2010, p. 74) mencionam - o primeiro com mais riqueza de detalhes - o episódio em que o carnavalesco Joãozinho Trinta, então no Salgueiro, copidescou o samba vencedor da disputa na escola para o enredo O Rei de França na Ilha da Assombração, apresentado em 1974.
} 
que eu entrei na vida. É muito engraçado escola de samba. Você se apaixona, passa a fazer parte da vida.

Eu era músico bem atuante, gravava todo dia, viajava muito, então não podia ir lá, mas era sócio. Quando finalmente eu me emancipei, parei de fazer aqueles trabalhos brabos de carnaval, aí eu passei a freqüentar a escola e a sair na bateria, tocando tamborim. Saí lá uns quatro, cinco anos, aí me escolheram para ser VicePresidente Cultural da escola, aí eu já não tocava mais, mas a minha ligação com o Império é na bateria. Fui presidente da ala de compositores, sou benemérito da ala de compositores, sou compositor da escola e, lógico, sou baluarte da bateria. Para lá é que eu carrego os meus filhos. Aprendi muito no Império Serrano, sobre a nossa vida de músico, como fazer e como não fazer, entende?

Sempre fui músico, nunca fiz outra coisa, não, e quando eu servi ao Exército, com 18 anos, eu comecei a estudar música. Aí quando eu saí do Exército já estava tocando, fazendo baile. Mas a experiência na escola vem desde criança. Eu ia lá pro candomblé do Joãozinho Dagoméia e os atabaques me fascinavam, aquela coisa, eu sempre gostei de percussão. É que eu tinha que ser músico mesmo.

Porque tem uns que são músicos. Minha neta, por exemplo: botei esse piano aí para ela estudar. Escuto tudo, menos o piano. Não estuda nada. Pode ser que meu bisneto vá tocar, porque nenhum deles é músico. Um filho meu está na fila de espera, o outro, Vinícius, pai dessas duas meninas, trabalha com futebol. É dessas empresas que compram e vendem jogador. É a mesma coisa com o samba: tem escritório para fazer samba-enredo. Você encomenda. Eles fazem dez, vinte sambas. Tem ala de escola de samba que paga carnê o ano inteiro. Estou dizendo a você que escola de samba acabou! Não é mais aquilo, e nem vai voltar atrás, se já tem escritório fazendo samba. De encomenda! Samba hoje é encomenda. No Império não tem encomenda, porque eles também não têm dinheiro pra pagar ninguém. Começa por aí.

Velha Guarda é o seguinte: existe a velha guarda da escola e a Velha Guarda "show"... O que eles dizem que é Velha Guarda da Portela, com o Monarco, aquilo ali é a Velha Guarda show. Mas velha guarda mesmo é a que sai na avenida com setenta, oitenta coroas dançando, entendeu? Não é porque é velha guarda que é compositor, às vezes não toca nada, mas desfila na escola, entendeu? É o mesmo amor, mas no show são dez, no máximo doze pessoas. No Império também tem, gravou um disco bonito, tem um repertório muito bom.

Entrei para a Velha Guarda do Império há algum tempo. Eu viajava muito e todo mundo perguntava:

- Das Neves não vem?

Tinha seu Fuleiro, Aniceto, Mano Décio, Carlinhos Vovô, Nilton Campolino, Tio Hélio, Djanira... Foram todos morrendo, só ficaram o Tio Hélio e o Campolino. O pessoal sempre perguntava:

- Mas cadê o Império?

Eu disse:

- Então vamos fazer, retomar.

E fizemos uma nova Velha Guarda. São todos velhos também: Aluizio Machado, Fabrício... E eu tive a idéia, não era pra eu ficar, só que pediram e acabei ficando. 
A Velha Guarda é complicada, de vez em quando as pessoas não levam muito a sério. E dirigir Velha Guarda é um problema: velho é cheio de mania. Eu não quero dirigir; se tem show, eu vou, mas tomar conta é complicado. Velho é pior que garoto. Pergunta pro Monarco! Pra dar uma idéia: a gente vai lá fazer show. O dinheiro tem que dividir certinho: vai dar quinhentos e vinte e três e cinqüenta pra cada um, tudo bem, vamos lá. Na hora de pagar, se fica faltando o trocado, o sujeito fala:

- Não, me dá meus três e cinqüenta

- Não, mas depois eu te dou.

- Depois não, eu quero agora!

Velha Guarda é assim.

- Eu quero meus cinqüenta centavos, me dá.

Aí tem problema, ele não entende que você não tem trocado, que o cara que pagou não te deu trocadinho. É bobagem, mas tem isso. Isso aporrinha, chateia. Não tenho paciência pra isso, não, trazer moeda de cinqüenta centavos... Na hora do show eles se empolgam... Mas são detalhes, assim. Roupa, por exemplo: a camisa é pra fora das calças.

- Ah, mas eu não quero, quero botar pra dentro!

Tudo é problema.

- Ah, mas eu não gosto, minha camisa eu só uso pra fora.

Bom, então ou todo mundo bota pra fora ou todo mundo bota pra dentro. Tem essas coisinhas. No fim já não fala um com outro, já fica emburrado, reclamando... Cheio de mania, cheio de sistema, não é? O Monarco conta que eles foram pra Brasília, isso há muitos anos, e chamaram para almoçar com o Presidente. Aí Seu Alberto Nonato - é Nonato, com "n" - falou:

- Não, mas eu não tenho compromisso com o Presidente, eu tenho compromisso com a Portela

Isso é o que eu estou sabendo, fora outras coisas que acontecem e que a gente não sabe.

Seu Alberto era muito engraçado, brancão, sambando, eu achava ele gozado pra cacete. Ele, Jair, na Portela eram todos meus amigos... Jair, Argemiro, Manacéa, Rufino, esse povo. Na Mangueira conheci Cartola, Carlos Cachaça, Jurandir, um monte deles. A Portela tinha uma ala de compositores braba. Mas você vê, nenhum deles faz mais samba-enredo. Por quê? Não adianta: se for dizer a eles como é que deve fazer, eles dizem:

- Então faz você.

Entendeu? Porque aquele pessoal da antiga, Lonato, essa turma, não está mais aí. Os mais velhos compõem o samba de meio de ano, mas samba de enredo não, nem samba de quadra. Porque precisa investir dinheiro em samba de enredo pra ganhar dinheiro, e samba de quadra não dá dinheiro. Eles não fazem mais, aqueles compositores antigos não fazem mais. Ficam de lado.

Sempre teve trânsito entre escola, sempre teve. Mas o compositor de uma não vai para outra, isso não tinha. Como é que eu vou falar "Mangueira, meu amor"? Isso era sujeira na roda. Você é Mangueira lá, Império é aqui, Portela é lá. É assim, não tinha esse negócio não. Agora eles mudam. Fazem um samba aqui, perdeu, vai para não sei onde. É assim... David Corrêa foi pra Mangueira, ganhou, foi pra Vila Isabel, ganhou, foi pra Imperatriz, ganhou, foi pro Salgueiro, ganhou, quando foi pro 
Império, dançou. Fez o samba, mas lá é ruim, hein? Pra todo lugar que ele foi ganhou, quando ele foi pro Império não deixaram, não. O samba dele não era o melhor, tinha melhor do que ele, e no Império é ruim de aceitarem esse tipo de coisa imposta. Bota um diretor de bateria no Império que não é da área pra ver como fica? Mas nem presidente fica, o cara se manca e vai embora sem ninguém falar nada. $\mathrm{O}$ Império é muito... É aqui, é daqui, não tem que chamar ninguém. Quem é de fora quer vir, venha, mas não vai levar nada.

O Império só não tem o dinheiro que os outros têm. O Império é uma escola democrática, o presidente é eleito pelo povo da escola. Todo mundo vota. Parece eleição de política. E na Portela é a mesma coisa, é eleito. Já nas outras escolas são consagrados... Aclamados... É diferente. Aí fica uma coisa meio desigual, não é? Porque você não tem esse respaldo... E eles não põem dinheiro, eles põem aval. Digamos que eu seja presidente do Império Serrano, vou comprar madeira lá, o sujeito quer cash, quer que eu pague à vista. Aí Castor de Andrade compra da mesma madeira, manda receber no escritório dele. E eles dão. Não é por intimidação, não: é o nome.

- Doutor Castor é homem poderoso

E tal, e pro Presidente do Império é:

- Que nada, amigo, se não pagar não leva!

A diferença é essa.

Se escola de samba não gerasse dinheiro eles não brigavam assim, desse jeito, pra ganhar samba-enredo. O único que não ganha dinheiro é o sambista. Esse vai lá, compra a fantasia, caríssima, e às vezes os caras dão até "volta", ninguém recebe fantasia nenhuma. Escola de samba agora é outra coisa, é show pra estrangeiro. $\mathrm{O}$ próprio brasileiro não tem direito a ver nada, porque paga uma fortuna pra sentar no camarote. Quando eles compram ingresso é pra concentração, o cara não vê nada, vê concentrando. Quem vai é japonês, é americano, alemão, inglês, e brasileiro que pode bancar. Mas não existe diferença, as escolas de samba são todas iguais. A única diferença é que uma tem e outra não tem - dinheiro. Só isso.

Mas é a mesma coisa que existir Vasco e Flamengo: não pode ter uma escola só, se não a Portela ia desfilar pra quem? Sozinha. Não ia disputar com ninguém. E a Mangueira, que é mais velha que a Portela? Só eram essas as duas poderosas, ganhavam tudo. Aí veio o Império Serrano, ganhou quatro anos seguidos. Já começou a encrenca, porque aí tinha rixa. O Império é a junção de três escolas de samba pequenas: Unidos da Congonha, Prazer da Serrinha e Unidos da Tamarineira. Porque não adiantava, três não chegavam a lugar nenhum. Salgueiro também: era Unidos do Salgueiro e Azul e Rosa do Salgueiro, uma coisa assim. Juntaram as duas, fizeram a Acadêmicos do Salgueiro. Paraíso do Tuiuti também: era Unidos do Tuiuti e Paraíso das Baianas, no mesmo morro. Juntaram e fizeram a Unidos do Tuiuti. Unidos de Lucas também. Vila Isabel não, Vila Isabel sempre foi Vila Isabel mesmo, Unidos de Vila Isabel. E o que mais? Mangueira também! Cada um tinha uma escola de samba lá em cima, juntaram pra fazer a Mangueira.

Tinha o morro, não era uma cidade que é hoje. Então a coisa era mais ou menos dividida. Uns faziam, outros faziam, tinham seus blocos, começava com bloco e ia virando escola de samba. Por um motivo ou outro:

- Ah, não gosto de lá não, vou fazer a bossa aqui. 
No fim chegaram à conclusão de que tinham que juntar. Eu não sei se a Portela juntou, porque a Portela era um bloco... A Portela não é de Madureira, não, ela é de Oswaldo Cruz. O Império também não é de Madureira, é de Vaz Lobo. O delegado de polícia é que botou o nome Portela, quando se tornou escola. Eles foram registrar, porque apanhavam quando saíam na rua, aí virou Portela, por causa do nome da estrada. Pergunta ao Monarco, ele conta essa história. Monarco foi criado ali desde garotinho... Sabe muito, acompanhou os bambas lá, aqueles compositores maravilhosos que tinha lá. Que a Portela tinha uma ala de compositores maravilhosa, o Império também tinha. Osório Lima, Avarese, Silas de Oliveira - o maior deles todos -, Nilton Campolino, seu Rufino, Aniceto, Seu Manel.

As mudanças no samba, isso é problema de mídia, de gente que foi dirigindo o samba pra isso, porque depois que a coisa foi gravada, o samba-enredo foi gravado, começou a ter dinheiro, então na rádio não tocava o samba quilométrico, como chamavam. O samba-enredo tem que contar uma história, você tem que contar por que aquilo; cada ala, ou cada quadro da escola, tem que contar o que vai acontecendo. O que estão cantando, está acontecendo. Escola de samba é o resumo da ópera. Só o Brasil faz isso, tocar, cantar, sambar, tudo ao mesmo tempo. Onde tem um espetáculo desses? Só aqui, e é o resumo da ópera, ópera é isso. Mas virou profissional, negócio de disco, aí a rádio não toca porque o samba é muito longo. Aí veio esse negócio de fazer samba de empolgação, que levante a arquibancada, mas se você prestar atenção nas letras dos sambas que estão concorrendo, falam a mesma coisa, do mesmo jeito. A sinopse não é pra você copiar, é pra você interpretar. Mas eles copiam, do jeito que o cara escreveu a sinopse o outro bota no samba. Fora as barbaridades que você ouve... Teve um samba no Império que o cara dizia: "lá em Guararapes, onde tudo começou...". Guararapes é o nome da guerra, começou o que? Aí você vai falar e o cara acha que você é que está errado, não tem discussão. Porque não é compositor, é comprôsitor. Aí geralmente você vê que sempre os mesmos ganham.

Silas de Oliveira ganhava tudo. Por quê? Porque era o melhor. E tinha cara bom lá, hein? Tinha cara bom, mas igual a ele não tinha. E você é culpado porque você é o cara? Pega as músicas dele, estão sendo cantadas até hoje aí. Já o do ano passado... Ninguém lembra! O samba empolgação, o samba de quadra, o samba que esquentava a quadra que era assim, um refrão, um verso, um refrão, um verso. E passou a ser o oficial, tiraram a história. Aí o camarada tem que falar em três estrofes uma história, aí ele fala o quê? Perde a inventiva, a pesquisa, a imaginação viajando pela história.

Getúlio Vargas foi quem liberou a escola de samba no Brasil, mas como contraproposta tinha que falar da História do Brasil. Hoje já tem astronauta, rainha do Egito, não sei o quê, isso não tem nada a ver com o Brasil. Eu sou nacionalista... Pato Donald, o que é que isso tem que ver com a História do Brasil? Hoje o Governo do Ceará bota o dinheiro, aí o filho do Governador sai trepado no carro, a mulher do cara, o neto... Aí é que eu digo: é uma covardia. Na hora que o negro lá do morro pode ser rei, aí você fala:

- Não, tu vai empurrar a minha alegoria, cara. 
É assim. E quem construiu aquilo? Foi ele, e ele não tem direito a coisa nenhuma.

Tem uma família de sabiá aqui em casa. Ah, aqui eu vou lá pro terraço, é um escândalo. Tem muito passarinho solto aí. Eu faço minhas músicas, gravando. Tem hora que pinta, tem hora que demora. Eu começo, mas não acabo, faço a música e dou pros parceiros, tenho muitos parceiros mesmo. De parceiro eu não estou mal, sou parceiro de Chico Buarque... Paulo Cesar Pinheiro, Aldir Blanc, Ivor Lancelotti, Claudio Jorge, Carlinhos Vergueiro, Nei Lopes, Nelson Sargento, Toninho Nascimento, Délcio Carvalho, fiz um pro Monarco botar a letra, mas ele não botou, o Elton Medeiros também não. Eu gravo na fitinha e dou pra eles. Canto, faço um cavaquinho sem vergonha, pra me acompanhar, e mando pra eles... Aí eles põem a letra. Quem dá o nome é quem põe a letra, geralmente. Às vezes pinta uma idéia, aí eu digo:

- Ó, tu põe a idéia assim, pra essa música.

O Nei é craque nisso. Falei pra ele fazer um samba em homenagem à Elizeth. Ele fez a letra. Em homenagem a Ciro Monteiro, ele fez, e à Velha Guarda do Império, que está nesse meu disco novo aí, que vai sair, dia 3 de dezembro, estou lançando. Pra gente fazer mais um samba. É uma música minha com Paulo Cesar Pinheiro que dá título ao disco. Dia 3 de dezembro no Teatro Tom Jobim, um dia depois do dia do samba. Dia do samba é dia 2. É a semana do samba, querem aproveitar isso para lançar meu disco. Estou gostando, está muito bom. Eu não corro atrás de nada não, deixo escorrer... Sou a matéria-prima, né não?

Nunca fiz samba-enredo não, Deus me livre, isso é pra arrumar inimigo de graça. Imagina eu fazer samba pro Império Serrano. Aí eu vou começar a escutar conversa fiada e eu não estou aqui pra investir, eu não ganho dinheiro pra investir em samba-enredo. No fim sabe quanto que eles gastam, cada um? Dez, quinze mil. Tudo é dinheiro. Por isso que eu digo, voltando ao princípio da conversa, escola de samba... Muda o nome. Pra mim não é mais, não. Por que é que eles botam a velha guarda no fim da escola? Pra não verem as coisas erradas, senão eles iam reclamar.

Eu não uso a escola. Eu eu sou músico profissional, acabei me tornando compositor, me deram oportunidade de mostrar minhas músicas, graças a Deus estou gravando, aí já fiz disco cantando, e tal, então eu não vou esquentar a cabeça. Tocaram pra mim um dia:

- Ah, seu das Neves, eles tão querendo que o senhor venha aí pra participar do júri, tão chamando os beneméritos...

Eu disse não. Tem um que não é compositor. Maurição é parceiro do samba, o outro é o realce. Eu, por exemplo, não tinha coragem de assinar uma coisa que não é minha. Também não vou deixar ninguém assinar o que é meu, não. O samba é meu, como é que vai enfiar o outro que deu o dinheiro? Não, não precisa dar nada.

Mas isso já vem desde Francisco Alves, que comprava samba. Nelson Cavaquinho vendia todos. Tem uma história do Nelson Cavaquinho com o Cartola, que eles só fizeram um samba juntos. Só um, conhecido. Aí ele fez o samba e Cartola botou a letra, e Nelson fez a melodia. Um dia o Cartola passou no Buraco Quente, tinha um cara cantando o samba deles dois, aí o Cartola falou:

- Ué, o samba é meu... 
E o outro ia dizendo:

- O samba é meu, é meu e teu!

Ele aí foi falar com Nelson:

- Que é que estão cantando o nosso samba?

E o Nelson falou:

- Já vendi a minha parte, agora tu acerta a tua.

Não é mentira não, Cartola contava isso. Nunca mais fizeram, foi o primeiro e último. Tava duro, dizia:

- Eu tô com um samba bom, aí, meu e do Cartola, quer comprar a minha parte?

O Nelson vendia, quantas músicas são dele e ele vendeu, ninguém sabe. Ismael e sua turma tinham dinheiro, não é? Os caras escutavam e...

- Isso é sucesso! quanto tá?

- 100 cruzeiros, paga uma sopa e tá tudo certo.

É a vida de sambista.

Isso de sambista se juntar, exigir, é uma coisa muito complicada. O povo brasileiro, a gente vive dessa maneira porque ninguém junta nada. Aqui cada um quer saber de si e ninguém quer saber de nada. Não importa se o vizinho está passando fome, isso aí é problema dele, daqui a pouco vai chegar aqui. Entendeu? Não tem essa consciência de que sozinho você não chega a lugar nenhum. A escola é a escola, não tem nada a ver com a vida particular de ninguém, que ninguém deixa. Todo mundo pensa "ah, mas a escola...", mas a escola não agrega ninguém. Antigamente se juntavam porque não tinha como, hoje tem um que banca, então não precisa de mais ninguém.

Antigamente se cotizavam. A comissão de frente da escola de samba antigamente, na Portela até pouco tempo, quem é que vinha na frente? Era a velha guarda. Antes, escola de samba tinha o livro de ouro, que era a contribuição dos comerciantes do bairro, que ajudavam com aquela importância pra fazer o carnaval, eles eram a comissão de frente. Porque eles tiravam o chapéu e diziam pro povo:

- Esse é o carnaval que nós pudemos fazer.

Essa era a finalidade da comissão de frente, não é isso que está aí. Por isso que eu digo a você: mudou tudo. Comissão de frente vinha andando, vinha mostrando a escola, geralmente a velha guarda, geralmente senhores, os administradores, diretoria, era isso. Hoje bota mulher grávida, bota mulher não sei aonde, o cara entra com uma caixa de som, é comissão de frente, mas não é autêntica. Você pode melhorar, mas não deturpar desse jeito. Mas eles acham que é tudo coreografia, e escola de samba não tem passo marcado, coreografia, a ala que fazia isso era a Sente o Drama, no Império, e só. E agora, comissão de frente dá salto mortal, e está apresentando o quê? Aqueles senhores que apresentavam a escola, e vinham andando, sambando. Geralmente usavam chapéu, paletó, gravata, e hoje o negócio está todo errado.

Faz outra coisa e diz o quê que é, mas não fica mexendo numa coisa que já é aquilo, não tem que mudar. Tem que melhorar aquilo, não mudar, isso sim. E quando a Viradouro botou a bateria trepada num carro? Como é que você vai tocar um instrumento? Tem que estar amarrado. O sujeito tocando surdo, o carro anda... Aí eles sentiram esse drama, ficava parado aquele carro, aí eles passavam por cima, 
saía, eles passavam pra cá... Quer dizer, bateria não pode parar, na bateria só se julgam três coisas: cadência, característica e não atravessar. Cada uma tem a sua característica, se ela começar assim tem que terminar assim, e não atravessou? Então é dez. Aí foi a Unidos do Cabuçu e disseram:

- Bom, a escola está bem: 9,8.

Isso é uma covardia! O que é que você viu pra tirar dois décimos? Então tira logo um ponto, sabe? Porque não tem o que tirar. Pra mim bateria já é hors-concours, porque são todas boas. Não existe bateria ruim, existe diretor de bateria ruim, incompetente, porque inventa coisa, quer aparecer. Mas não tem bateria ruim. Se elas pararem, acabou a festa. Não ganham nada e ainda fica o camarada atrapalhando o trabalho deles. Botam aquelas mulheres lá na frente, você querendo andar.

Mestre Marçal era diretor de bateria da Portela e disse:

- Não pode, quero andar com a bateria, mas tem aquela vagabunda!

Aí elas disseram que ele não gostava de mulher, ele respondeu:

- Não, eu gosto sim, mas não é na frente da bateria!

Saía empurrando:

- Quero andar com a minha bateria e não consigo!

Aí fica aquele buraco. Vem aquela mulher rebolando, pára tudo, fica clec-clecclec-clec-clec, tirando fotos, e você quer vir, mas como é que vai vir, cadê?

Natal levou Marçal para a Portela por causa de um pé de sapato. Isso aí é do meu tempo de garotinho, Marçal foi até capa de disco. Na hora de pegar o sapato deram dois pés direitos pra ele. Muito fácil de resolver, mas ele tomou aquilo como se estivessem dizendo que era aleijado. Aí ele foi falar com o presidente, que disse:

- Não cria problema...

E ele:

- Então fica com a tua escola aí.

Isso deve ter mais de cinqüenta anos. Aí ele entrou para a Portela, Natal quis empurrar uma cativa de diretor de bateria lá. Mas ele morreu imperiano, mesmo. A família dele era toda do Império, a mulher dele. Antes de morrer, voltou, veio de volta. Claro, porque ele não estava em escola nenhuma. Falei:

- Pô, vamos voltar pra casa.

- Ah, não, que os caras vão querer problema comigo, que eu larguei pra lá...

Que nada, chegou lá, o povo todo batendo palma pra ele. Mestre Marçal.

Agora o filho dele está aí. Marçalzinho é meu afilhado, e eu sou um bom pai. Ele está na Itália, vai pra Itália, esses dias aí. Ih, é o percussionista que mais trabalha com Martinho, trabalha com esses cantores todos aí, João Bosco e não sei quem, todo mundo chama, e tem o bloco dele, o Sorri Pra Mim, que sai da Vila Isabel.

E eu estou aí, no meu Império Serrano, não tem jeito, não dá, não tem como mudar, não. Tudo aqui é verde - essa imagem de meu pai Ossain, que eu ganhei, não é bacana? Um amigo lá de Belo Horizonte, chamado Alexandre Segundo, mandou fazer e me deu. Ele tem sempre um galho de folhas na mão.

Mas diga. 
Ivan Milanez durante apresentação da Velha Guarda do Império Serrano no Portelão. Acervo pessoal da autora, dez. 2010

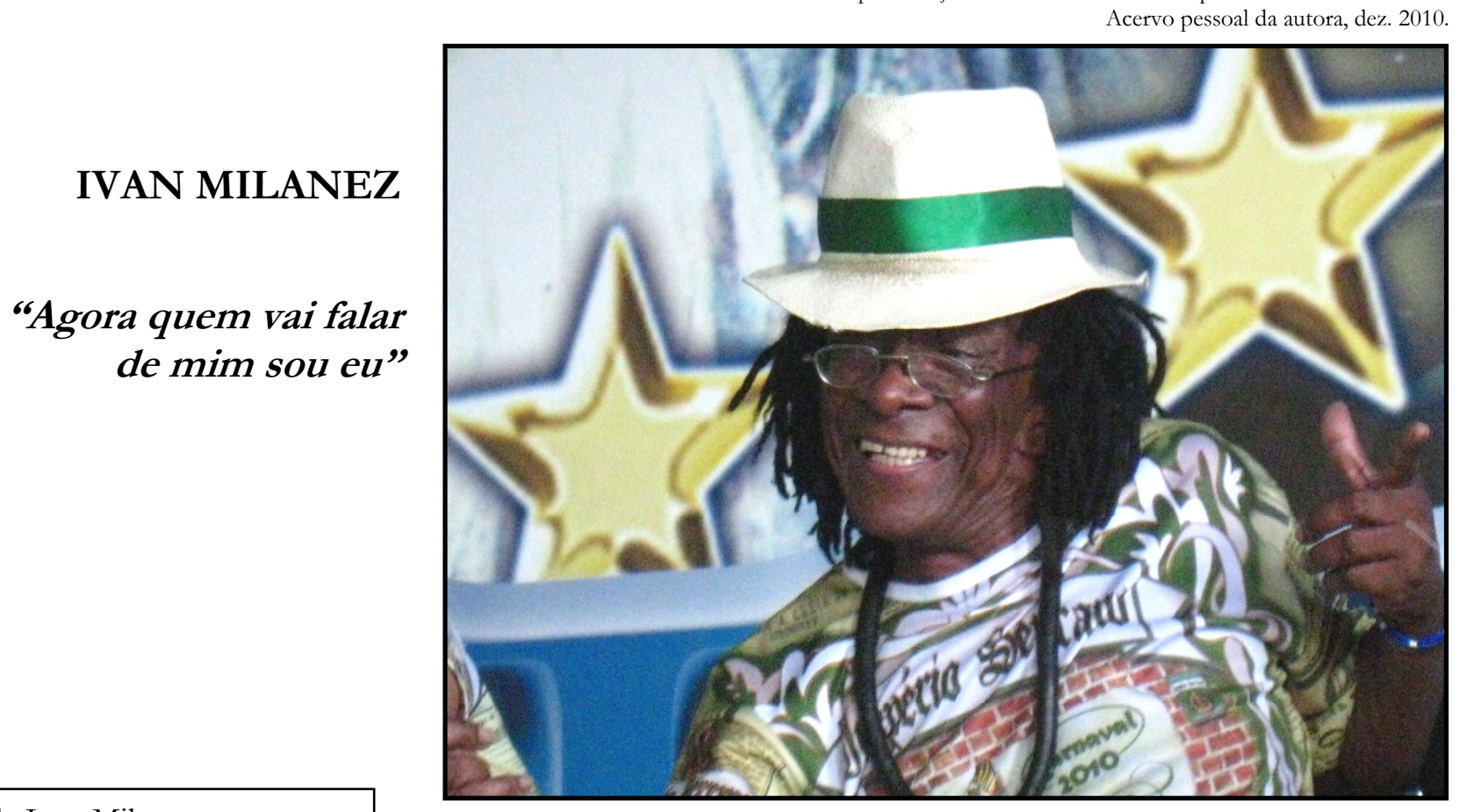

Lugares de Ivan Milanez:

1. Serrinha

2. Santo Cristo

3. Rocha Miranda (Largo do Sapê)

4. Madureira

5. Vaz Lobo

6. Colégio

7. Madureira

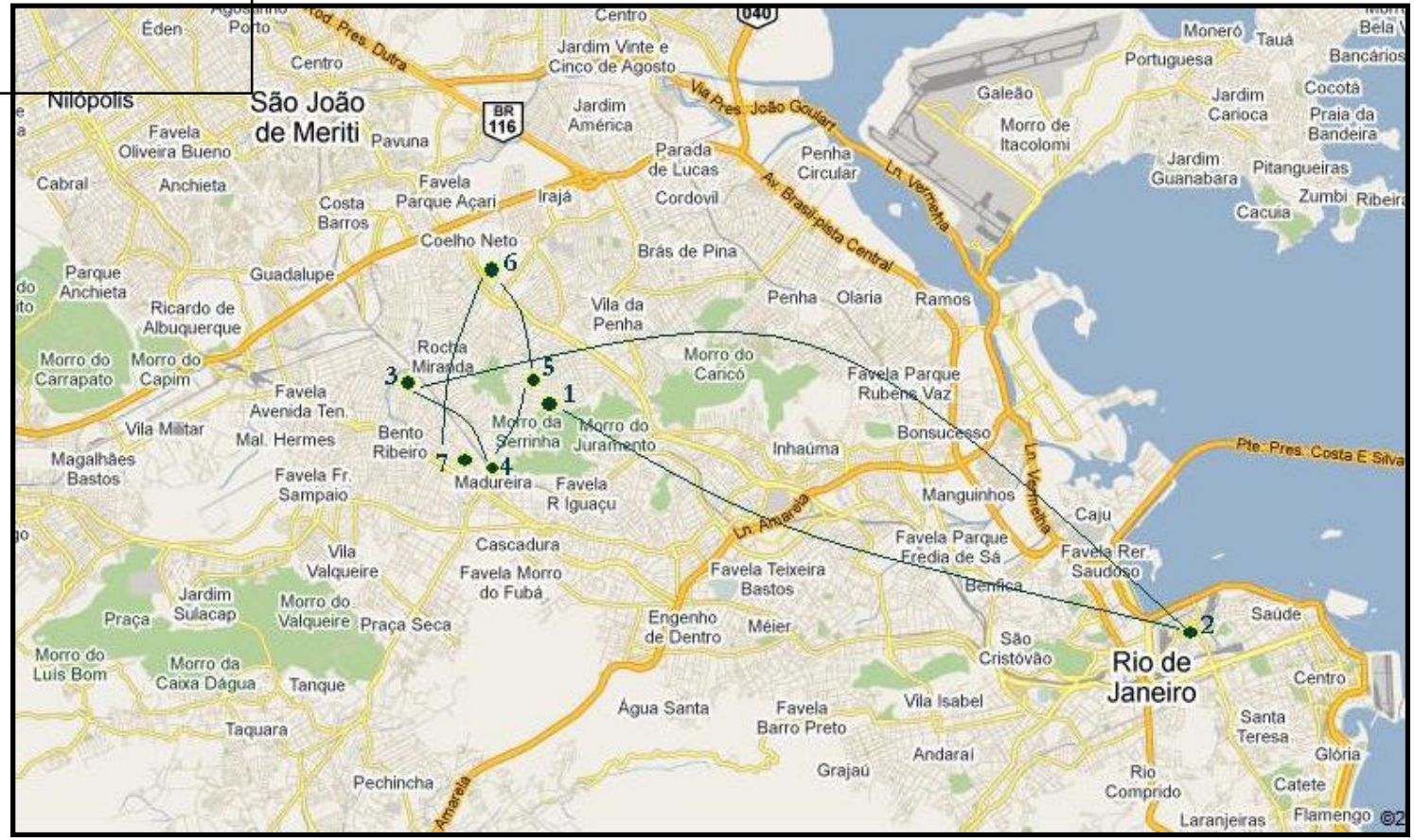


É importante começar lembrando a data de hoje, dia 2 de fevereiro, esperando que Iemanjá nos traga novas esperanças. A minha trajetória no samba começou praticamente de berço, porque minha mãe não era passista nem nada, mas ela fazia fantasia para o Império Serrano. Quando eu nasci, eu realmente não tinha nem noção do quê que era o Império Serrano, mas com o passar do tempo...

A gente ficava ouvindo meus pais, meus tios, vizinhos, inclusive eu morava na mesma avenida que a Dona Ivone Lara, que eu não consigo chamar de Dona Ivone Lara porque eu me acostumei chamá-la de tia Ivone Lara. Todo dia eu saía da minha casa, já ia tomar café da manhã na casa dela, e aí escutava as histórias, como é que foi fundado o Império, e isso a gente vai guardando na memória. E, com o decorrer do tempo, minha mãe, quando podia, me fantasiava pra desfilar. Numa determina época, ela me levava lá embaixo para ver sair as alegorias do Império, que era tudo feito lá em cima, de modo artesanal mesmo: o cara que é pintor é que fazia os desenhos da fantasia, o componente, tinha uma arte, entende? Tinha um tema, e aí, o que é que eles faziam? O tema era... Tiradentes. Era sempre História do Brasil em geral. Então os carnavalescos entravam nesse momento, tinha um que idealizava uma história. Cada escola tinha esse momento. Então ali, ele passava pro compositor, o compositor tinha livro, lá, ia ler, trabalhava, tirava aquilo e dali ele criava o samba. Bom, isso é a fase que eu conheci mais ou menos. Então comecei por aí, vamos dizer assim.

Minha vida em casa era normal, de irmãos éramos só eu e minha irmã. Minha mãe costurava para fora... Ficava lá com aqueles trapos, e ela tinha que trabalhar pra sustentar o casal, então não tinha muita regalia para fazer muitas coisas, não. Com meu pai a gente não teve quase contato. Aqueles negócios deles lá, mas intimamente era uma pessoa legal. Isso aí é uma coisa que eu não posso nem dizer como é que foi. Em relação a mim, não tenho muita coisa para falar, nem de ruim, nem de bom. Eu digo isso porque as pessoas, quando me viam, sempre relacionavam com as amizades que ele fazia. E dizem que eu sou do mesmo tipo de relacionamento; eu ouço, até hoje, que faço da mesma forma que ele fazia. Independente dos problemas dele.

Ele era imperiano. Fazia parte da fundação do Império, foi diretor de bateria, um dos primeiros. Até eu ia um pouco, muita gente nem se lembra. Ele era conhecido como Dinho. Naquela época não tinha esses negócio de mestre de bateria. No máximo o que tinha uma bateria eram dois dirigentes. Hoje em dia, na escola de samba, tem dirigente de tamborim, dirigente de palma, dirigente de etiqueta, tem dirigente de tudo, mas você olha para uma bateria de escola de samba, é o maior barato.

Minha mãe sempre falava que eu sempre gostei de estar envolvido, pegando nos instrumentos. Tinha muita roda de samba lá, na Serrinha, então eu era aquele garoto intrusão mesmo, eu via lá, aquelas rodas de samba do mestre Fuleiro, Silas de Oliveira, Ivone Lara. Eu era aquele garoto que chegava lá, pegava os instrumentos. Alguns mandavam parar, outros:

- Deixa o garoto...

E não sei quê.

- Ele vai bem. 
Tinha aquelas histórias assim, com meus colegas também, e às vezes eu tentava arranhar um violão. Só que depois de uma determinada época, tinha que estudar, tinha colégio, então não dava muito tempo para a gente ficar tão dentro de escola de samba. Só quando tinha visita, aí minha mãe me levava lá pro morro, para assistir aos ensaios, mas eu não desfilava, eu não era assíduo assim.

Era tudo muito rígido, tinha restrição de idade, ou tinha que acompanhar os pais... Os garotos que desfilavam, as crianças da minha idade - de seis, sete anos - às vezes, até os de dez anos de idade, normalmente eram filhos de diretor, e o diretor tinha uma facilidade maior de arrumar permissão pra desfilar. Então como que minha mãe fazia? Ela, como costurava um pouco para as alas, me colocava, botava uma fantasia da minha irmã, que era uma baianinha, ou qualquer coisa que tivesse na época, e botava uma fantasia, com a cor do Império Serrano, mas eu só ficava por ali, e ela me levava para Madureira, me lembro bem... E pra todos os efeitos, eu estava desfilando no Império Serrano!

A partir dali, cheguei a passar por outros lugares, desfilei em outros blocos. Eu sempre fui envolvido com samba de uma certa maneira. Inclusive desfilei em blocos fora mesmo de Madureira, fui convidado para um bloco

- Ah, convida esse garoto aí que ele é lá do Império Serrano.

Que eu fui morar em outro lugar, quando fundaram um bloco ali no Largo do Sapê. O Largo do Sapê, para quem não sabe, é em Rocha Miranda. Então tinha um bloco lá, como eu não podia desfilar no Império, com meus oito, dez anos, não me lembro bem... Mas lá podia, porque o desfile era só no bairro. Então não tinha esse negócio. Para desfilar, minha mãe juntava minha irmã e eu e ia para a avenida, ver o desfile. Mas a gente, mesmo, não desfilava, porque a gente não tinha idade pra isso. Quer dizer, praticamente eu comecei a me envolver com o Império a partir da maioridade. Antes não tinha muito envolvimento, mas sempre gostando, assim como curtia outras coisas, também.

Curtia outros tipos de música, com certeza, porque eu vivia todo o tempo ouvindo Império Serrano, indo para o Império Serrano, mas só que também gostava de ouvir outros ritmos musicais, até porque... Minha mãe disse que eu, quando dormia, acordava batucando, sonhava batucando. Quer dizer que... Essa minha relação com o ritmo já vem desse tempo. E olha que eu não ficava muito envolvido assim, não. Quer dizer que, então, eu ficava ouvindo, é claro, e muitas coisas eu sei da história do Brasil porque eu ficava igual àquele garotinho, assim, fingindo que não estou vendo nada, mas escutando tudo. Criança é assim, não é? Todo mundo:

- Ah, ele não tá prestando atenção.

Que nada, estava sim, prestando atenção, e lá eles contavam as histórias da fundação, de quem fez, quem não fez... Até que, dos meus 13 até meus 18 anos, eu não era envolvido diretamente com escola de samba em geral. Eu ia, quando me levavam, tia ou tio, ou amigo dos meus pais, mas naquela época não tinha aquela responsabilidade de ser assíduo.

E também eu estava na influência de tudo, porque era a época da minha adolescência. Na pré-adolescência eu peguei twist, aquilo ali era... Quando se fala que o brasileiro pega ritmo importado, naquela época já se pegava, tanto que o americano sempre foi, sempre existiu aquele imperialismo... A gente até não tinha noção, que muitas vezes a juventude de hoje tem. Logicamente que a gente era 
influenciado por esse ritmo que vem de fora, e eu estava no meio dessa rapaziada, como é que eu ia, naquele momento, pensar em ir para escola de samba, se todo mundo da minha juventude ia curtir rock, depois veio black? Veio uma porção de ritmos, a soul music. Até os meus 20 e poucos anos, eu ainda curtia esse lance.

Claro que eu estava sempre na escola de samba, a partir dos meus 20 anos. E eu ficava vendo, ensaiando lá, eles tinham me chamado, me convocado para sair no primeiro grupo de samba show do Império Serrano, aliás foi até um pouquinho antes de completar 20 anos, porque realmente, tinha ala de lá que não dava para a gente sair, até por questão financeira mesmo, que a escola não oferecia condições...

Aí fizemos, a gente saiu no conjunto Samba Show Imperial. Mas só fui me identificar mais com o samba quando o Império veio para a Avenida Ministro Edgard Romero ${ }^{51}$, onde era o antigo Mercadão de Madureira. O Império antes estava sem quadra. Mas nesse período eu não era muito assíduo por causa dessas outras influências, às vezes eu estava numa festinha, se formava uma festinha, todo mundo sabia que eu era Império Serrano, sempre era apontado como o "escurinho do samba". Quem falasse de samba vinha falar comigo, mas só que antes do samba eu também gostava de namorar, e minha namorada não ia para samba. Até porque, o negócio era a influência do ritmo importado, que era o rock, era o twist, aí veio a turma da Jovem Guarda, isso tudo nós curtimos, a gente da minha geração... Nessa minha época de adolescente, poderia ser até do samba, mas curtia muito isso também, porque eu era, como se diz, um produto da época, então eu participava disso, automaticamente.

É tudo problema de época, não é? Cada época é uma época, a gente não pode querer também ficar aqui detonando... Se o time não estivesse dando certo, aí teria que manter aquilo, mas como está dando certo, aí se fazem essas mudanças. Eu acho que são até bem-vindas, porque poxa, hoje em dia... Até eu peguei um bom período sendo diretor de bateria, ia à frente da bateria com bastão e um apito. Hoje em dia eu acho até complicado, para a gente que pegou essa época aí, a gente tem que fazer até um curso, porque agora pros mestres de bateria é tudo no sinal, dedo pra lá, dedo pra cá, mão pra cá, e nem a gente consegue entender. Antigamente era mais simples... Mas tudo é problema de momento, é produto de época mesmo. É legal também. Não tenho muito o que falar disso, não.

Hoje em dia eu desfilo todo ano. E também, há dez anos agora, eu fui convocado para representar, digamos, um grupo que já existia no Império Serrano, que era o dos fundadores da escola. Alguns anos atrás existia um grupo que representava o lado musical da velha guarda do Império, a Velha Guarda show. Então há dez anos, numa gestão da ex-presidente, ela pediu para convocar algumas pessoas. O Império e todas as escolas estavam formando Velha Guarda musical. Então, quando fomos convocados, tinha filho do mestre Fuleiro, outros eram sobrinhos do Seu Zacarias, que foi um dos fundadores. Eu, também, todos os parceiros que estão na Velha Guarda hoje. Quando não é filho de gente que participou desse movimento. Tem alguns que têm parentesco com alguém que fundou a escola. Então nos convocavam:

\footnotetext{
${ }^{51}$ De acordo com Valença \& Valença (1981, p.66), a inauguração da sede na Ministro Edgard Romero aconteceu em 23 de outubro de 1964.
} 
- Primeiro, vamos ver se o pessoal ainda está... Disposto a sair, que ainda tem gente viva aí que está em pé, aí. Vamos saber a disposição deles, nós não vamos já entrando assim, de cara que, nós não podemos, não estamos com...

Vamos dizer na gíria, não é?

- Não estamos com essa bola toda pra querer representar a velha guarda do Império Serrano, que nós não fundamos a escola, primeiro temos que perguntar aos primeiros, que fundaram.

Foi quando eles liberaram:

- Não, deixe que a gente está fazendo outras coisas, vocês fazem, representando...

Foi um dos fundadores que disse, que teve essa idéia de fazer a segunda gestão da Velha Guarda musical, que é a Velha Guarda show. Aliás, o Império, quando voltou com esse grupo, foi o primeiro grupo a denominar Velha Guarda show Imperial. Hoje em dia todas as velhas guardas estão falando, fazendo isso. Porque as pessoas, quando falavam assim:

- Ah, tem uma festa da ala, tem uma festa da velha guarda de tal escola em tal lugar.

Aí, coitado, o pessoal não sabia e confundia, achava que a gente ia fazer show nesse lugar. Então nós somos a Velha Guarda, mas representando o lado musical desses que foram os fundadores. Quer dizer, nós somos a parte, como se fosse, uma espécie de uma segunda geração da fundação do Império. Porque se for botar no caderno, todo mundo que está nesse grupo agora, praticamente nasceu junto com o Império, então tem muita coisa para dizer... Tem história pessoal, tem que ouvir falar, não é?

Velha Guarda show é diferente da velha guarda, eles acabam sendo a velha guarda para quem tá chegando também, sem dúvida. Agora, eu posso dizer assim, sou velha guarda justamente pra quem está chegando, mas ali tem velha guarda da escola de samba, que são outros. São as pessoas que vieram daquela época, da escola, os caras que vêm do tempo... Vamos dizer assim, para não deixar ninguém de fora: tem gente que fundou e tem gente que é da época da fundação. Tem essas coisas. Pessoas que vieram da época da fundação.

E as pessoas que são da época da fundação, são eles a velha guarda. Nós somos seguidores, a segunda geração... Quer dizer, somos velha guarda porque nós somos a segunda parte dessa velha guarda que já existia. Que toda escola, eu pelo menos quando eu era criança, quando estava estudando, ainda na fase de ouro, eu sempre ouvi falar em velha guarda, em ala de velha guarda. Sempre existiu, porque muita gente pensa que... Foi bom ter essa oportunidade de explicar às pessoas, para passar para outros, que a velha guarda, quando a pessoa que está fora, imagina assim: o cara que é da velha guarda, imagina um senhor muito sábio que vem... Isso é normal, não é? Mas não é muito isso não, porque de repente, quer dizer, a velha guarda de uma escola de samba, de uma agremiação, não necessariamente tem que ser idoso, não. Até porque, você de repente começa com 10 anos, até ajuda na fundação de escola, mas com 40 anos você está jovem ainda e já é um cara da velha guarda, porque começou com 10 anos. É um exemplo, para a pessoa entender.

E de repente chega um cara com 50 anos, começou lá com 50 anos de idade, ele não tem nem um ano de escola de samba. Mas você vê o cara e pensa "não, esse cara, 
esse aí deve ser velha guarda", vem com aquele chapeuzinho típico, "nossa, esse aí deve ser...". E se não está informado vai entrevistar:

- Pô, quem é aquele cara, aquele ali?

Às vezes o cara que tem 60, 70 anos, mas nunca saiu, é a primeira vez que saiu, não sabe nada. Então por isso que eu explico às pessoas: velha guarda na realidade, não é... É claro que a idade influi, sem a menor dúvida. Mas na realidade o que conta é o tempo que você tem na agremiação. Porque tem gente que começou tarde. Muita gente começou tarde, já começou bem adulto, pra lá de adulto. Quer dizer, o cara às vezes tem, por exemplo, o Império tem 53 anos, mas de repente, tem gente que chega lá no Império com 50 anos e não é velha guarda, nunca, e às vezes o cara com 30, quando ele fala, dizem:

- Pô, vem cá, mas você tem mais histórico do que ele para contar!

Será que deu pra entender? Já existia uma velha guarda, de show, musical, mas não é ala da velha guarda, que em todas escolas de samba sempre existiu. Porque se olhar direitinho, até uma escola praticamente recém-fundada, por exemplo... Porto da Pedra, a escola recém-fundada e o sujeito diz:

- Ah, não era pra ter velha guarda.

Mas tem, porque ela às vezes é oriunda de um grupo com outro nome. Se juntavam ali, faziam, até com outro nome. Então o cara coloca como velha guarda, porque até chegar Porto da Pedra... Já estou dando o exemplo da Porto da Pedra, que é uma escola praticamente recém-fundada. Vou dar um exemplo melhor: inventamos um grupo aqui. Qual é o nome do grupo... Vamos ver um nome aí qualquer. Flamenguistas Unidos. Daqui em diante, o outro monta uma escola de samba: Unidos do Flamengo, mas essa escola de samba veio oriunda de quem? Dos Flamenguistas Unidos. Então alguém pergunta:

- Ué, mas a Unidos do Flamengo nasceu, só tem um ano, como é que tem velha guarda?

Tem, porque ela veio daqui. É esse lance que as pessoas às vezes confundem, porque tem que ter tempo de escola. Não é questão de ser mais velho ou mais novo, que às vezes tem cara que é novinho e sabe muita coisa que a gente não sabe. Claro que no cômputo geral, é aquilo que eu digo, aqueles senhores, é lógico que podem saber mais, mas desde que não tenha ficado... Que tem gente que parou no ar. Não é necessariamente quem nasceu há mais tempo que sabe muita coisa, não, tem muita gente que está ali, estagnou e não sai mais, aí a pessoa vai bater de frente com o cara, porque, quando for perguntar alguma coisa, ele não vai saber.

Não tem um critério de quem vai ser da Velha Guarda, mas o cara observa:

- Bom, fulano já foi compositor da ala, já foi da bateria...

Foi convocado, tem história na escola. O critério é que tem que ter história na escola, por isso que eu falo: não basta ter 50, 60, 70 anos para ser Velha Guarda show. Mas numa ala de velha guarda, aí já tem esse critério. Com 20, 30 anos o sujeito não sai numa ala de velha guarda. Até os 30 anos não pode, dos 40 pra cima todas as escolas de samba têm critério, a maioria. Mas tem lá: velha guarda tem que ser a partir dos 40, quem já tem uma história, o cara que já vem desde os dez anos, então já tem uma boa história... Agora, por exemplo: o pessoal da minha geração que participa da Velha Guarda show, especificamente, todo mundo tem uma história 
como passista, a maioria já saiu na bateria, outros já saíram de mestra-sala, empurrando carro alegórico...

Eu já fiz tudo isso. Já fui de tudo. Bateria, saí de passista, fui componente da ala Sente o Drama, uma das primeiras alas de passo marcado das escolas de samba, participei da organização dessa ala no Império Serrano, aí veio todo mundo atrás. Hoje em dia tudo quanto é escola tem ala, mas vai ter sempre a lembrança dessa ala, porque foi a grande coqueluche da época, dos anos 1960, 1970, todo mundo queria... Naquela época dava para pular com uma mão só o muro, na plataforma da Central do Brasil. Mas agora não, a rapaziada está toda já caindo para lá dos 60... Depois do "enta" complica, né? Até o "inta" você ainda pode fazer tudo, agora, depois do "enta", já vem a idade do Condor. Com dor em tudo quanto é lugar. Passou dos quarenta, não tem muita chance não, tem que ir devagar, entende? Tem que aproveitar enquanto está na linha do "inta", porque no "inta" o cara ainda está bonachão, bonitinho. Eu me lembro, quando era mais novo, tinha uns 13, 14 anos, eu ainda não era muito envolvido com música - também comecei na música tarde. Vamos dizer, para dizer direito, imbuído mesmo, posso dizer que tenho 40 anos de samba, que é uma boa estrada também. Até porque eu nasci praticamente junto, na mesma época que a escola, então nem daria para ter mais... O Império é de 1947, então não tem como.

Necessariamente, quando se fala que tem tantos anos lá, é quando já está envolvido, participa de ala, mas tempo de adolescência, em geral, é correr com pipa, ir para festinha. Eu sou do tempo de festa americana, do cuba libre. Era tão americanizado que a gente não tomava cachaça, tomava cuba libre. A expressão não é portuguesa, então devem ter importado essa maneira de se divertir de outros lugares. Então a gente normalmente faz um cálculo assim, quando participa depois de adulto... Eu comecei a participar mesmo a partir dessa idade, 20, 25 anos, e por isso eu posso dizer que eu tenho 40 anos assíduo de samba. De samba em geral, quer dizer que eu também participei de muitas outras escolas de samba como convidado, desfilei no Estácio, na Imperatriz Leopoldinense, mas sempre desfilando no Império, até porque na nossa época, da minha geração, com a época mais moderna, a gente se interligava.

A geração anterior à minha era mais complicada, você tinha que sair naquela escola, e não tinha esse negócio de um falar com o outro, não. Eu me lembro quando eu ia visitar a minha tia, que era Portela. Ela era minha tia, mas sabia que o meu negócio era Império Serrano. Eu chegava todo prosa lá, e ela:

- Você tá muito bem, meu filho.

E depois:

- Queria até responder a tua benção, mas por enquanto... Você deixa mais um pouquinho... Se você tivesse com uma roupa azul e branco, até te abençoava.

Eles eram fogo! Lembro uma vez que um colega meu foi lá, no Império. A Tia Eulália era a primeira sócia do Império Serrano, e um amigo nosso, o Cizinho, que hoje está na Velha Guarda show do Império, teve uma época - depois que começaram esses intercâmbios, assim, ninguém se importava - mas teve uma época que ele desfilou bastante, ele também foi da ala Sente o Drama. Depois que ele foi da ala Sente o Drama ele passou a ser mestre-sala do Império Serrano, mas só que depois veio aquela história... Não existia isso, antes, o cara quando saía numa escola, 
saía até o fim. Já a nossa geração mudou tudo que vinha, porque veio a época do "quem dá mais", entendeu? Então o cara mudava mesmo, componente da escola, eu conheci, o cara precisava, e ia mesmo... Aí então uma vez ele conta que foi lá na casa da Tia Eulália, passou por lá:

- Pô, Tia Eulália, tudo bem com a senhora? Gostou dessa roupa?

- É, tá bonita essa roupa, mas num sei o quê que veio fazer aqui com essa cor aqui, com essa roupa.

Era azul e branco... É que a geração deles era mais... A nossa já foi diferente, que a gente era, com esse negócio de passista, todo mundo que ia fazer show no mesmo lugar se encontrava, então a gente fazia show junto com componentes de outra escola, se misturava mais. A minha geração é a da década das grandes mudanças, graças a Deus eu tenho felicidade de dizer que eu venho de uma geração de jovens que fizemos uma grande mudança no país, e talvez no mundo, que aí começou a era da Jovem Guarda, da Tropicália, do twist, dos Beatles, dos hippies. Quer dizer, nós pegamos uma boa época, entre a década de 1960 e 1980, vamos dizer até que a gente teve uma grande vantagem, acho que a minha geração teve, que eu falo até em termos mundiais. Porque a minha geração teve muita participação nessa mudança que foi a gente falar, porque antes a gente não podia falar, pegamos um tempo de Ditadura em que não se podia falar nada, e nós conseguimos brigar com isso, pra ter o direito de falar, de ouvir e de falar. Eu acho que essa geração que veio depois da nossa tem até que agradecer muito a nossa coragem.

Trabalho, eu já fiz vários... Trabalhei em oficina mecânica, em vários lugares, mas sempre pensando na música. Mas em tudo que eu fiz praticamente eu sempre fui autodidata. Aquilo que eu disse antes, minha mãe falava que minha avó dizia para ela que eu vivia batucando, não é? Dormindo... Então comecei, sempre procurava tocar percussão, aí teve uma época que eu conheci Roberto Ribeiro, no início da carreira, que eu não era nem músico... Vou dizer profissional, mas não sei se o termo legal seria esse. Eu não era dedicado, basicamente não tinha noção. Porque o meu lance, às vezes a gente fazia as rodas de samba e aí era piquenique, eles convidavam para tocar um pandeiro, para cantar um pagode, mas sem pensar em profissionalismo nenhum não. E depois que eu conheci Roberto Ribeiro, foi a primeira pessoa com que eu trabalhei dentro de estúdio, que eu nem sabia o quê que era estúdio direito, eu ficava admirado, ficava ouvindo Fundo de Quintal tocando na minha casa, a roda, já botava para tocar assim, isso eu já via... Mas à vera mesmo fui começar a partir dos 30 anos, entende? Que eu tocava, e tal, conhecia, foi quando eu fundei o Grupo Família, todo mundo ficava dentro da casa onde eu morei, morava junto com minha irmã. Como não tinha lugar pra ensaiar, nós ensaiávamos lá, aí eu fundei o Grupo Família...

Isso era em Madureira. Era o primeiro grupo organizado para acompanhar o Roberto Ribeiro, ele já no início de carreira. E aí, então, sugeriram que colocasse o nome no grupo, todo mundo deu várias idéias - aliás, eu sou bom nisso, sou criativo. Aí tinha um grupo foi formado por um cunhado do Roberto Ribeiro, três irmãos e um concunhado. E eu era amigo, eu convivia com eles, com a família, fazia aquela coisa, nós tínhamos um bloco, aí pediram e eu sugeri Grupo Família. Até porque, se a gente não era parente, a gente era compadre um do outro, de maneira que tinha um certo parentesco. 
Aí foi um tempo com o Roberto... Comecei a pensar, gravar em estúdio... Gravei alguns discos com ele, em estúdio. Os coros, coisa assim. Depois com o tempo, dei uma paradinha, e aí depois conheci Zeca Pagodinho. Foi quando eu trabalhava num estúdio aqui na Central, aí a gente gravava tudo. Se isso fosse registrado... Eu estou entre os caras, junto com meus amigos, somos das pessoas que mais gravaram fita concorrente de samba-enredo de todas as escolas de samba. Não tem uma escola de samba que eu não tenha gravado os sambas concorrentes, a maioria. Eu e meus amigos da época. Disco oficial eu não gravei tanto assim, gravei pouco. Gravei muito pouco. Mas para escolha de samba-enredo - das escolas, claro, aqueles sambas a gente gravava pra eles concorrerem nas escolas de samba, quem gravava era o nosso grupo.

A idéia desse grupo, o projeto com que o Robertinho começou a carreira, ele estava já porreta, começou logo arrebentando a boca do balão, então ele não esperava tanto assim e acabou tendo que fazer um grupo para ele. Contou para a rapaziada, aí todo mundo ficou naquela coisa de botar o nome do grupo, num sei quê, num sei quê lá, e como é que vai ser o grupo, aí eu sugeri: Banda Molejo. Depois é que fizeram o grupo Molejo lá, isso foi depois... Porque o pai de um dos componentes do grupo Molejo era um dos componentes da Banda Molejo, que era o Bira Hawai, e eu que sugeri esse nome. Ah, só que às vezes têm a memória curta, entendeu? Naquela época eu não tinha nem a intenção de registrar nada. Tanto o nome, Grupo Família, como... Hoje tem um bocado de gente aí com o nome, Grupo Família para uma porção de coisas. O único registro que eu tenho do Grupo Família é lá na SOCINPRO (Sociedade Brasileira de Administração e Proteção dos Direitos Intelectuais). Que todo mundo ia se registrar lá, então, era esse grupo que nós gravamos $C D$, e que acompanhava...

Essa é a luta que você sabe como é que é. Tem gente que já começa no primeiro gol, tem gente que tem que levar dez anos para fazer um gol, para ser sucesso. Então é uma carreira que eu não aconselho... Independendo do estudo. Tem que gostar. Claro que estudando é melhor ainda. Na minha época a gente tinha mais é que gostar e estudar mesmo. E sorte, que às vezes não é só o talento que te leva, se não tiver sorte naquilo...

Eu componho, mas comecei mais tarde também. Sabe por quê? Eu me identifiquei, eu estava muito como acompanhante dos cantores. Uma hora acompanhava o Roberto Ribeiro, às vezes acompanhava Almir Guineto, fiz batera para Alcione, Beth Carvalho, que era um tipo de free lance, assim. Então, eu custei muito a me mancar. Aliás, eu fazia algumas coisas, mas aquilo ficava por ali, entende? Mas eu não me tocava que isso era uma corrente boa. Eu ajudava até os parceiros a desenvolver o samba deles, andava, ia atrás. Mas não entrava na parceria, até porque eu achava que não era legal, apesar de que tem muita gente que fez isso... Tinha acesso, né? E eu tinha muito acesso, à maioria dos artistas. Mas eu nunca tive essa pretensão de fazer samba. Se o cara, de repente, colocasse, aí era... Mas eu não pedia. O cara dizia:

- Ó, eu vou colocar você.

Tá certo, eu vou gravando.

- Ó, fulano, eu gravo, mas tem que botar meu nome... 
Isso eu nunca fiz. Não sei nem se eu posso censurar quem aceita isso, sabe por quê? Porque existem coisas que você tem que pensar antes de censurar. Existem vários fatores: a necessidade, o momento. Dizem que na década de 1940 os compositores vendiam as músicas, por necessidade. $\mathrm{O}$ cantor chegava:

- Vou gravar você, se ele me der a parceria.

E essa porcaria é antiga, hein? O pior é que eles ficavam pensando que eram malandros. É sempre assim, vai passando a geração, a que vem sempre pensa que é mais malandra que a que passou. Aí eu penso, realmente, esses caras já aprontavam...

Na minha época, o pessoal já acordava mais, porque a gente se ligava mais no assunto dos escravos, escutava as histórias do tempo em que roubavam samba, roubavam música... Aí realmente, tinha gente que exigia, que tinha que dar parceria para entrar, para determinado cantor, que estava fazendo sucesso. De uma certa forma, era válido, porque de repente o teu barraco está... Você olha pro teto, parece até que não tinha teto, chovendo pra caramba, tinha que comprar telha. Isso é a necessidade, não é? Não é questão de fulano pegar, às vezes é porque o outro é pobre, são duas vertentes. Noutro dia bate na porta... E o quê que tem? Se o cara falar para ele assim:

- Olha, eu vou gravar a música tua, mas você tem que me dar parceria. Você sabe quanto é, os direito autorais?

E o cara:

- Não.

Às vezes ainda é passado para trás, porque ele não sabe de nada, para ele aquilo tudo é novidade. Compositor nunca entrou em estúdio, chega lá, fica deslumbrado, ele está precisando de um real, aí o outro chega perto dele:

- Aqui ó, você vai gravar com Alcione...

Ou com sei lá quem.

- Consegui, mas você tem que me dar a parceria. Mas vai assinar, direitinho, tal...

Dividindo a parceria.

- Não, claro, dou o samba, dou...

Só que a edição, vamos supor, é de R\$10 mil. Pô, o cara está ganhando muito! Você acha que ele vai pensar em não dar a parceria pro sujeito? É a necessidade de cada um, isso não comporta as pessoas estarem censurando.

- Ah, que eu não me vendo!

Eu já vi muitas pessoas dizendo isso e acabaram mudando de lado. Eu posso dizer que eu resisti muita coisa... De algumas coisas eu acho que eu pude abrir mão. Também não é nada de mais, eu dar parceria, não vou eu pegar parceria só porque eu tinha acesso. Eu achava isso exploração, o cara que me conhecia ali, para eu pegar as músicas dele, mesmo que desse para um cantor que era meu amigo gravar e eu dar a parceria. Mas só que depois eu fui olhando que eu poderia fazer isso também, entrando em um acordo com o cara, mas as pessoas já fazem...

- A tua parte foi censurada.

Muita gente faz isso de maldade mesmo, o cara não tinha noção.

- Pô, você que fez a música sozinho, num tem que dar parceria a ninguém! 
Mas para mim, em compensação, você estar com dinheiro é bom, a tua necessidade é que manda. Você não grava e não tem nem pão para levar para comer pros teus filhos. O canal, meu canal é você, é você está fazendo disco, aquele samba que eu vou ganhar R\$ 20 mil, mas se eu ganhar 10, para mim, está valendo 100, que às vezes ele pode fazer por 10 , e isso não é de censurar.

É claro que é um problema de não valorizar o compositor. É por isso que tinha que discutir esse negócio, dizer pra todo mundo:

- Gente, compositor faz isso porque não é valorizado.

Ele não teria que dar parceria a alguém se pudesse ganhar sozinho. Claro que tem esse problema de falta de... Valorização. Isso aí de agora, por exemplo, é uma coisa terrível. Você vê onze caras assinando. Eu sou do tempo que a minha ala de passista no Império Serrano, a gente que influenciava, não decidia, porque ainda não era assim, mas influenciava o samba quebrado, porque era um samba que era de bom estado, influenciava o resto da platéia, mas de compositor eram só dois, eram dois contra dois adversários, não se via... O máximo que se via numa parceria eram três pessoas. Hoje em dia tem 20 numa parceria! E às vezes, um parceiro hoje, veio falar comigo isso, disse:

- Pô, Milanez, você vê só, né? Sabe o que tá acontecendo? Ou a gente faz ou num faz, né, porque num tem jeito, tem que estar, é assim, num tem jeito. Veja, se você quiser fazer é assim.

Naquela época, os caras que faziam samba-enredo, a gente via aqueles caras fazendo realmente com carinho, e um compositor não saía de uma escola para ir pra outra. Depois que veio esse problema do LP de samba-enredo é que mudou muita coisa. Veio história de cronometragem, que a escola não tinha cronometragem para desfile, o pessoal saía descontraído, com prazer, ficava lá dando volta. Aí passou a ter... Passou a se gravar o samba-enredo, ainda não era nesse nível, era um amigo que tinha uma grana, dizia:

- Ah, vamos gravar o LP da tua escola.

E quatro se cotizavam e gravavam um LP. Depois que apareceu a gravação em CD, sumiu o vinil, até porque antes, no LP, eram duas faixas e a bateria. Aí, começou a surgir o $C D$, passou a ser gravado. Infelizmente, dizem que a mola-mestra do mundo é o dinheiro, e o dinheiro mexe com as pessoas. Começou o compositor também a gravar com outros interesses. Aí é que começou a aparecer parceria com o fulano que era o dono fábrica de sabão, aí botava, Seu Manoel Português, dono da padaria, agora é parceiro. E um cara, também, por si só, não tinha outro jeito. Os outros entravam, ele também tinha que entrar. Estou falando isso porque agora a gente reclama, todos eles, mas não tem como, ou você entra ou não entra.

Agora, não estou aqui para ficar teimando, reclamando disso, estou dizendo porque você vê, você vai conhecer esse pessoal que samba melhor, que não tem torcida... Porque agora tem isso. Pô, outro dia um sujeito teve a capacidade de me falar - o meu samba foi escutado no Império Serrano este ano, meu samba com meus parceiros, nós disputamos com o que ganhou - aí uma pessoa teve a capacidade de falar assim:

- Poxa, Ivan, faltou pôr um cantor bom.

Antigamente, naquela época que eu era garoto, não tinha esse negócio de ter um cantor, eu não quero um cantor bom. Cantor ajuda, mas não resolve... Pega um 
cantor bom... Então hoje em dia os critérios são diferentes. Ou você faz ou não faz, porque ou tem que ter um cantor bom, aí tem que ter dez ônibus... E você não tem dinheiro... Na época desse pessoal anterior, acho que não existia pagamento para se inscrever samba-enredo. $\mathrm{Eu}$ acho que não, tem que procurar pesquisar isso melhorzinho, porque eu não estou tão convicto disso, não, mas eu acho que não existia não.

E não é de hoje que tem, não, há bastante tempo tem. Isso aí depois é só ver, pesquisar, quando começou a gravar o samba oficial, é só ver a época, que foi a partir dessa época que começou esse negócio, aí você começou ver três, quatro compositores... Deve ser mais ou menos 1960, por aí. Até porque, o Grupo Especial das escolas de samba, que realmente entraram nessa direção, era muito... O carnaval passou a exigir muito mais grana, mais o papel bordado, para a rapaziada fazer o carnaval bonito. Então, às vezes tinha escola que passava dificuldade... Então, precisava ter um cara que conseguisse fazer esse negócio de gravar CD, que também ajuda. Só que, com isso, também vieram outras coisa que não poderiam acontecer, mas infelizmente é o que está aí.

Minha carreira é o seguinte: ainda é circuito de músico. Velha Guarda só é uma coisa nova pra mim. Eu não era participante do grupo, não tinha intenção de participar de grupo mais nenhum, era só carreira individual, como compositor, depois que descobri essa veia poética que eu nem sabia que tinha. Comecei a andar para esse lado, aí o pessoal começou a ver que eu cantava, e coisa e tal, comecei a fazer uns showzinhos por aí afora, foi até bom, porque eu não tinha jamais essa idéia, então para mim é... A Velha Guarda show foi uma coisa, assim, de satisfação, por eu ter sido lembrado, por ter sido filho de uma época. É mais uma questão de prazer. Agora, como carreira, não sei não... Até porque não posso dizer que já fui bemsucedido financeiramente como músico, porque não fui. Mas é uma coisa que eu sempre gostei, e que eu gosto de fazer, que eu já venho fazendo há vários anos. Mais de 30 anos de carreira...

Se fosse pelas coisas que eu percebi na música, que não consegui, eu já até teria até desistido, mas eu realmente faço uma coisa de que gosto, e em compensação a música me levou a alguns lugares que acho que se eu não fosse músico não teria chegado... Não trabalharia com pessoas, nem alcançaria lugares que alcancei, nessas minhas andanças aí. Com o dinheiro, por mais dinheiro que eu tivesse, eu não batia com essas pessoas que eu consegui trabalhar, muita gente com grana não conseguiu entrar. Tenho essa satisfação. Financeiramente, eu não posso dizer que tenho, não, porque eu já estou insistindo há bastante tempo. Mas é uma coisa que eu gosto, é aquele negócio que eu costumo dizer para as pessoas que perguntam:

- E aí, Ivan, como é que é, vai descansar?

- Eu não, bicho, tô vivo, eu num morri!

$\mathrm{Eu}$ estou aqui, estou vivo, estou fazendo as coisas dentro daquilo que for possível, de acordo também com meu talento, com as honras que eu tenho, com o poder que eu tenho. Eu posso subir, mas meu talento vai ficar para alguém que me copiar. Alguém aí me colocou como um dos melhores percussionistas do mundo e, no entanto, financeiramente, eu não funciono. Isso é o mais engraçado. Tem pessoas que começaram e com um ano já conseguiram sua independência financeira como 
músico, como cantor, como artista. Agora, a Velha Guarda show é legal. Enquanto eu puder, vou ficando, se de repente eu... Deslanchar pra outro lado, começa outra.

Quando me perguntam de sucessão na Velha Guarda, eu não vejo como sucessão, não... Sucessão para mim é outra geração que vem depois da minha. Bom, é claro que tem um grupo de pessoas que pode substituir o que está aí, isso aí claro que a gente sabe. Todos os compositores, cada um tem sua vida particular, não tem que ser... Ninguém é totalmente preso a esse negócio de Velha Guarda show, não tem que fazer só show com a Velha Guarda, cada um tem a sua vida, eu tenho a minha carreira como músico, como artista, o Wilson das Neves tem a carreira dele já bastante firmada como cantor, o Zé Luiz do Império, o Aluizio Machado, até porque eles também, não eram só músicos, tinha funcionário público que fazia alguma coisa porque precisa de grana, mas carreira como cantor e compositor, não necessariamente era da Velha Guarda show.

Esse grupo que está aí é só para manter uma coisa que já não existia mais dentro da escola, que todas as escolas tinham grupo de show, grupo para fazer show. O Império é que tinha parado, mas justamente foram os fundadores que vinham no grupo, então eles pararam. Nessa época era a Portela, até porque, você vê: a Velha Guarda show, para show, da Portela, só foi formada por ala, por componente da ala de velha guarda, que foi formada por compositores do tempo antigo da escola, então foi pegando os compositores mais antigos, tinha uma escadinha assim, tinha aptidão para compor e para cantar, que muitas vezes o povo ali da velha guarda nem conseguia fazer um grupo...

Isso eu soube, então pegavam os grupos. Na realidade, a Velha Guarda show se dá assim: pega-se componentes antigos, mas que eram compositores. A maioria não era da ala da velha guarda. Eles estão ali representado o lado musical da escola de samba, portanto, você pode ver que a maioria das escolas de samba que fizeram grupo de Velha Guarda, na música, a maioria é de compositores, gente envolvida com música, porque o pessoal da velha guarda, mesmo, a maioria tem paixão, sai com a escola, todo mundo se encontra, conta a história, quem fundou, coisa e tal, mas já o público de escola de samba é um pouquinho diferente, de velha guarda, para tocar é um pouquinho diferente, porque não tem o cara que vem da bateria, o cara que saiu de passista, o cara que cantava na noite com a rapaziada da escola, aquela pastora que puxava, mas isso era da ala da velha guarda, coisa que não...

Então eu não digo sucessão, eu digo substituto. Sucessão é outra história, tem que esperar o cara subir o morro, para botar outro. Porque você vê que a Velha Guarda que está aí, na Velha Guarda da Portela tem pessoas que estão lá que não são do tempo da escola, mas foram substitutos dos pais... O Serginho Procópio, filho do Osmar do Cavaco, a Áurea Maria, filha de Seu Manacéa, a Neide, do Seu Chico Santana, são pessoas que não eram da época deles. Aí sim, aí é sucessão. Agora, no nosso caso, no grupo, pode se arrumar um substituto. E também tem isso, não pode ser qualquer um, o cara pode ter sido compositor, dentro da escola, mas não pode... Dentro da escola tem que ter juízo, não é? Não vou chamar um cara que é de outra escola de samba:

- Ah, mas ele tem história...

Não quero história, a história dele é lá... Não é a questão de idade, é questão de tempo, ter uma história na escola. Às vezes o cara tem 30, 40 anos, mas: 
- Não, esse cara sai desde garotinho, ele ajudava a limpar o carro...

Tem que ter uma história, não é o sujeito dizer assim:

- Ah, eu tenho 50 anos.

Nada disso, pelo menos no grupo musical, não tem isso de:

- Ah, eu tenho 50 anos, eu já posso sair, eu toco muito, olha...

- Mas vem cá, qual é a história que tu tem nessa escola de samba? Esse aqui ó, tem 40, mas acontece o seguinte: ele pode ter começado a sair com 40, mas ele saiu na escola desde os 15 anos. Eu, que já estou com 60, tenho, e sabe por que ele tem também? Porque o pai dele fundou a escola, então tem tudo isso guardado, o histórico dele, ele é menino, mas ajudava a emendar, a encourar um tamborim, ele tem história, você, chegou com 50 anos, mas você fez o quê na escola?

É essa a explicação que as pessoas têm que ter, quando chegarem. Tem que saber, quando saem esses caras velhos, de velha guarda, qual é a história dele na história de determinada escola de samba, porque ele pode não ter nenhuma. Ainda mais agora, que aparecem esses macopebas nas escolas de samba...

As escolas estão com um problema muito sério, eu acho até que a gente tinha que tomar uma atitude. $\mathrm{O}$ cara vem, na incógnita, no intuito às vezes até de ajudar a escola de samba. Aí eles perguntam assim:

- Pô, porque é que fulano tá nessa, tá exercendo essa função aí?

O cara chegou agora e já está... Comandando.

- Ah, não, é porque ele tem acesso onde nós queremos.

Antigamente o cara chegava dentro da escola de samba e, para pegar algumas coisas, ele morava até, aí virava subúrbio. Ele ia ali, tum-tum-tum-tum-tum, ele sabia mais da escola de que você, naquela época. É a história do mau pesquisador: eu chamo mau pesquisador, que não era verdadeiro. Ia lá, estudava, então, na época desse pessoal, dessas escolas mais tradicionais, eu já garoto observava isso. Os caras chegavam lá e, poxa, o pessoal normalmente é de uma situação monetária, de uma classe, bem sacrificada. O outro chegava um dia, ia lá, fazia uma festa, arranjava sempre uma tia no lugar, não é? Então o cara começava, vinha "minha tia", aí então o cara bancava feijoada, bancava não sei mais o quê, mas só para testar, que esse pessoal da nossa geração anterior não tinha essa maldade, não. Então daqui a pouco o cara estava virando padrinho:

- Ah, porque ele é muito bom.

Na minha geração tem uma porrada, surgiu um montão deles, mas a gente aí responde:

- Ô, meu irmão, quer ajudar na minha casa, você pode botar o que tiver na metade, mas quem vai mandar na minha casa sou eu.

E hoje em dia ainda está havendo isso, que tem também em escola de samba, a pessoa chega lá, é diretor... Porque é formada em não sei o quê... Formada em várias coisas aí, e...

- Ah, não, tem que botar o cara formado nisso, com alguma coisa.

- Sim, pô, mas vem cá: antigamente eu acho que nossos pais, da escola de samba, num tinha ninguém formado não.

Mas é aquela história... E formado em quê que tem que ser? Formado em quê? Entende? Não sei disso, agora tem que ser um cara formado, e daqui a pouco eu estou vendo o cara com duas alas, antigamente o cara tinha duas, três alas, um cara 
só, porque tinha condições financeiras para custear. Mas essa coisa ainda existe. Você vai ao ateliê de uma escola de samba, vai pegar uma camisa, e de quem é a camisa? É do diretor do patrimônio de não sei o quê. Hein? Nunca foi à escola de samba e já é o diretor de não sei de quê. Ele já tem um ateliê, e a camisa é ele que tem. Às vezes pegar uma camisa já é difícil, chega um cara do nada aí, vira diretor, e daqui a pouquinho já tem uma fábrica de chapéu, para vender na escola. O cara só tem dinheiro, e o componente da escola, eu, lá: quê lá...

- Pô, quero comprar uma camisa, pra vender, com o nome da escola, num sei

E a gente descobre que o cara já é dono. Eu que sou de lá, não tenho esse direito. Aí descubro que o cara é diretor... Social, quando eu falo diretor social, estou falando pessoas que têm que impor já, ter aquela obra, até porque a bandeira foi ele que criou, é ele que fez a faixa, não vai ser capaz de dizer:

- Olha, é o seguinte: eu tô aqui com o meu, posso tirar aqui as camisas, com logotipo, que eu dou dinheiro... O tema da escola é o seguinte, olha: a fábrica é minha, as camisas fui eu que comprei...

Então a gente precisa chamar atenção das pessoas para ver esse lado. Vai perguntar ao seu Molequinho, que foi o primeiro fundador da escola, se ele tem alguma fábrica para vender alguma coisa, ou a algum parente dele se tem. Porque o Império foi fundado na mesma família. Vê se algum parente do meu amigo Helton, que é neto da primeira diretora, primeira sócia do Império Serrano, pergunta se ele tem algum lance lá, para ele vender umas camisas. Se fizer isso, nêgo vai cortar dele. Hoje, de repente, você descobre a fulana que veio num sei de onde, que é diretora social, e a fábrica é dela. Eu fiquei, assim, besta, de pensar que a gente fica fazendo samba, e para quem é que está fazendo? Não temos condições de, de repente, computar aquilo, e nós vamos, não temos grana pra isso. Aí você descobre que um cara que não pegou isso, que não era da família de ninguém, quando eu falo isso não falo do Império Serrano não, eu falo desses diretores de escola que apareceram. Foise o tempo. Se depender de mim, tem que botar isso para fora, tem que ter alguém para mexer com isso aí, que está demais. Está demais.

Como é que pode, você que criou, que ajudou a criar o negócio, você não fez com intenção de ter lucro financeiro, mas no momento em que você vê alguém com lucro, eu quero o meu também. Por exemplo, participei da recriação do Pagode do Trem, e hoje em dia eu tenho que perguntar se eu posso entrar. Eu estou até exagerando um pouco, mas um cara pega financiamento, o outro é porque botou uma firma... Até falei, mas aí:

- Pô, Milanez, pra fazer isso tinha que botar a pessoa que entende.

- Vem cá, mas quando nós começamos a reviver esse Pagode do Trem, num tinha professor fulano de tal...

Não tinha. Quer dizer, então, aí já foram perguntar:

- Mas você acha que o Milanez conseguiria segurar isso?

- Ué, Milanez, e as pessoas que estavam no início, não estão mais na direção?

Foram perguntar. Se nós levamos avante sem ter pesquisador, sem ter gente formado em negócio de finanças, aí nós conseguimos levar, depois que o negócio cresceu, acabou, aí a gente não tem mais condição para fazer. Dez anos, sem nenhum investimento, aí o fulano pegou R\$ 50 mil de financiamento em tal lugar, pegou uma 
barraca em tal lugar, e o nosso, nem um tabuleiro tem para levar um café, não é nem para ficar, mas pra tocar samba, pensar "eu gastei, mas estou sendo beneficiado de uma certa forma". Tem gente que não tem nada a ver mandando, com crachá, e estou aproveitando para dizer isso claramente.

Porque até se tiver que polemizar, eu quero mesmo. Tem coisas que eu tenho datas, posso não ter gravado, mas tem coisas que eu tenho datas de como começou. Eu, por exemplo, comecei o pagode dos Arcos da Lapa com um amigo aí... Há dez anos começamos o pagode dos Arcos, outro "pagode", assim, entre aspas, foi o primeiro pagode antes de começar, depois que começaram a ir outros parceiros aí. Hoje em dia eu diria que só está o Marquinhos de Oswaldo Cruz que criou, embaixo dos Arcos. Depois deu uma parada, um pouquinho, aí fui convidado, primeiro, para fazer esse pagode embaixo dos Arcos, um cara que é vivo até hoje, por isso eu posso falar à vontade. O cara que puxava lá está vivo até hoje. Por coincidência ele chamou o Marquinhos e nós juntamos as idéias, mas o primeiro convidado fui eu, e pouca gente sabe disso. Eu não falava nada, porque...

Bom, foi um amigo meu que me indicou. Ele participava de um movimento lá, do Lima Barreto, ali em Piedade, então ele me chamou, chamou o cara que foi procurar por ele, que era o Jair, dono de uma casa que chamava-se Arco da Velha. Foi lá e falou que estava querendo fazer um pagode embaixo dos Arcos, para tirar aquela tensão que tinha. Ele queria aproveitar que pegou a casa, então um amigo, que era um pintor renomado aí, envolvido com esse negócio da cultura do samba, do subúrbio, em geral, ele me indicou:

- Ó, o cara mais indicado pra falar com você é o Ivan Milanez, até porque tem muita estrada, faz um trabalho bacana...

Por coincidência ele também conhecia o Marquinhos de Oswaldo Cruz, tocou no assunto, aí o Marquinhos foi me procurar, eu digo:

- Tudo bem.

E fomos tendo as idéias. Com dificuldade, fizemos o primeiro pagode lá. Aquela coisa era deserta, aturamos aquilo ali pelo menos umas três semanas, depois o negócio estourou, de maneira que não dava nem para andar. Aí, o quê que acontece? Depois de determinada época, nós tivemos um probleminha, paramos, aí fomos para a Fundição Progresso, aí nêgo foi chegando, fazendo umas coisinhas, aí fui convidado também pra fazer uma roda de samba, a primeira roda de samba na Rua Joaquim Silva, era numa casa de produtos naturais. Então o Moreno, que é amigo nosso, também do Doutor Bigu, através do JR tinha um espaço que era da família dele, que vendia produtos naturais. Então, como não tinha nada, ele disse:

- Poxa, isso aí dava um espaço pra você fazer as coisas tuas, porque a esposa, as mulheres podem fazer a comida, coisa e tal, e a gente dirigia a roda de samba.

- Tudo bem, vamos fazer.

Fizemos por um tempo. Daí, não tinha nada na Lapa, a Lapa era deserta. O máximo, que de vez em quando eu era chamado ali, era para a Casa Brasil-Nigéria, para aqueles lados ali, tinha um amigo que dava uma explicada ali para uns universitários que quiseram aprender samba. Eles faziam aula de percussão na UERJ, mas queriam mais algumas coisas, aí me chamaram para dar umas dicas para eles. Eu digo: 
- É o seguinte: eu sou autodidata, eu sei que vocês que têm faculdade, têm professor de percussão de faculdade, como é que eu vou saber?

- Ah, mas só que lá, essas manhas aí, a gente num consegue fazer.

Aí ensinei a manha a eles. Aí é que está, voltando, lembrando a situação que falei do início de tudo com as escolas... Resumindo, e vou até incluir meu amigo, o Doutor Bigu que está aqui presente e eu tenho certeza que acompanhou isso tudo, essa evolução e essas confusões todas. A partir daí, depois apareceu uma casa lá chamada Semente. Antes tinha uma casa cubana, que era só de música, que tinha que marcar pra fazer samba, na Joaquim Silva, depois que eu fiz a primeira roda de samba, não tinha nenhuma casa de samba, depois surgiu essa casa chamada Semente, que foi onde apareceu esse grupo aí com a Teresa Cristina, que na realidade essa moçada ali da casa também tinha o nosso código, foi o primeiro... Hoje em dia dizem que foi lá que começou, e resultado: aí vem aquele, não vou dizer latifundiário, mas aqueles caras que montam, posso falar na gíria. O cara que está com o bolso cheio, que pode ganhar mais, ele vem com idéia, dizendo que a gente não tem idéia, daqui a pouquinho vem o cara, abre uma casa, mas nem eu mesmo posso entrar, fica aquele papo de tirar crachá, ninguém quer saber se fui eu que comecei aquilo.

Não precisa de nada: há alguns anos, a Rua do Lavradio também era abandonada. Aí o Rogério Bicudo, quando veio para o Brasil, começou a andar comigo, ele mais o Doutor Ricardo, começaram a idealizar que a gente fizesse uma roda de samba, ali na Rua do Lavradio. Não fizemos. O samba que fizemos, nós fizemos em homenagem aos grandes mestres, que ainda estavam vivos, graças a Deus, o Xangô da Mangueira, fiz uma homenagem a ele, mas com a intenção de fazer isso pelo menos de 15 em 15 dias homenageando os grandes. Porque os grandes mereceram muito. Os caras que fizeram a história do samba, não é? Nós somos um seguimento, a nossa geração foi um seguimento dessas pessoas. Então a gente estava querendo perpetuar isso.

Mas, quando estávamos fazendo isso, daqui a pouquinho apareceu associação:

- Num pode fazer, precisa ter...

Hoje em dia é diferente, a Rua do Lavradio. Casa tinha, antiquário, mas nem todos pretendiam fazer... Algumas casas começavam a fazer negócio de chorinho... Mas não roda de samba, absolutamente estava incluído o samba. São lances diferentes. Tudo é samba, mas só o que fez isso de roda de samba, popular, na Rua do Lavradio, nós começamos a fazer, mas aí começou a aparecer um monte de gente, ninguém queria nem botar o pé. Nesses alturas, o que acontece? O sujeito:

- Pô, tem grana envolvida...

E desenvolveu. A gente faz essas coisas sem pensar, a gente não pensa "bom, se eu fizer isso aqui eu vou ganhar dinheiro", a gente até esquece disso, o entusiasmo não deixa a gente pensar nisso. Aí, nessas casas... Se perguntar quem sou eu, não sabem quem sou eu. Às vezes você encontra uma pessoa que já diz:

- Pô, esse cara fez isso aqui, assim, assim, assim.

Mas não é uma coisa que vai saber, não tem documento para ver...

Hoje em dia todo mundo sabe, todo mundo agora apareceu. É a história do filho feio: enquanto o trem estava vazio, ninguém queria ser dono do Pagode do Trem. Agora, o trem cheio, todo mundo é dono. Quando o trem era vazio, que era 
quatro, cinco cabeças, ninguém tinha coragem de meter a garra. E na Lapa a mesma coisa, quando estava cheio de gente dizendo que tinha medo de parar numa roda de samba, nós conseguimos trazer essas pessoas pra cá, pro Centro. Ninguém tinha coragem, mas agora que o filho ficou bonito, apareceu. $O$ filho feio não tem pai.

Dessas casas todas, a que chega mais perto de respeitar o sambista hoje, na realidade, é o Carioca da Gema, que combina com as pessoas. Você vê, agora eles estão tentando sambista em todo lugar, quase tudo eles fazem assim. Mas não ocorre de ter alguém que tem escola nisso aí, eu acho que se você me vir uma vez na vida tocar numa casa lá da Lapa, ou cantar, ou qualquer história, é muito, porque eles só pegam trabalho pronto agora. Porque eles vão chamar o Tantinho da Mangueira, e não é porque o Tantinho da Mangueira tem história no samba, oriundo do grupo fundador da Mangueira, mas só porque ele está sendo comentado. Os caras não buscam, eles querem só o que está pronto, e é isso que eu estou falando. Aí de repente:

- Ah, vamos botar o Milanez ali nessa roda.

Agora, se tivesse uma faculdade, as mãos ficam mais fáceis, é o que o Paulo César foi que gravou, que disse, essa força.

Em relação às pessoas escutarem uma história aí, a meu respeito, eu tenho que dizer que, até um certo tempo, quando começaram a contar uma história minha por aí, eu ia e deixava rolar, pensava "ah, deixa pra lá", mas só que agora, de uns tempos pra cá, eu resolvi dizer que quem tem que falar de mim sou eu. Que eu não me pareço com ninguém, não sou igual a ninguém, sou igual a mim mesmo, então quem tem que falar de mim sou eu.

Não tenho disco gravado, mas vou gravar, vai ser solo. Não tem data marcada, isso aí é uma questão de... Mas tem um outro lado, que eu vou mostrar, é um registro... Claro que eu quero que dê certo, que o certo é isso que se diz: quem é que não gosta de carinho? 
Lindomar durante apresentação da Velha Guarda do Império Serrano no Portelão. Acervo pessoal da autora, dez. 2010.

\section{LINDOMAR}

\section{“Quero ter tempo para} curtir mais a vida"
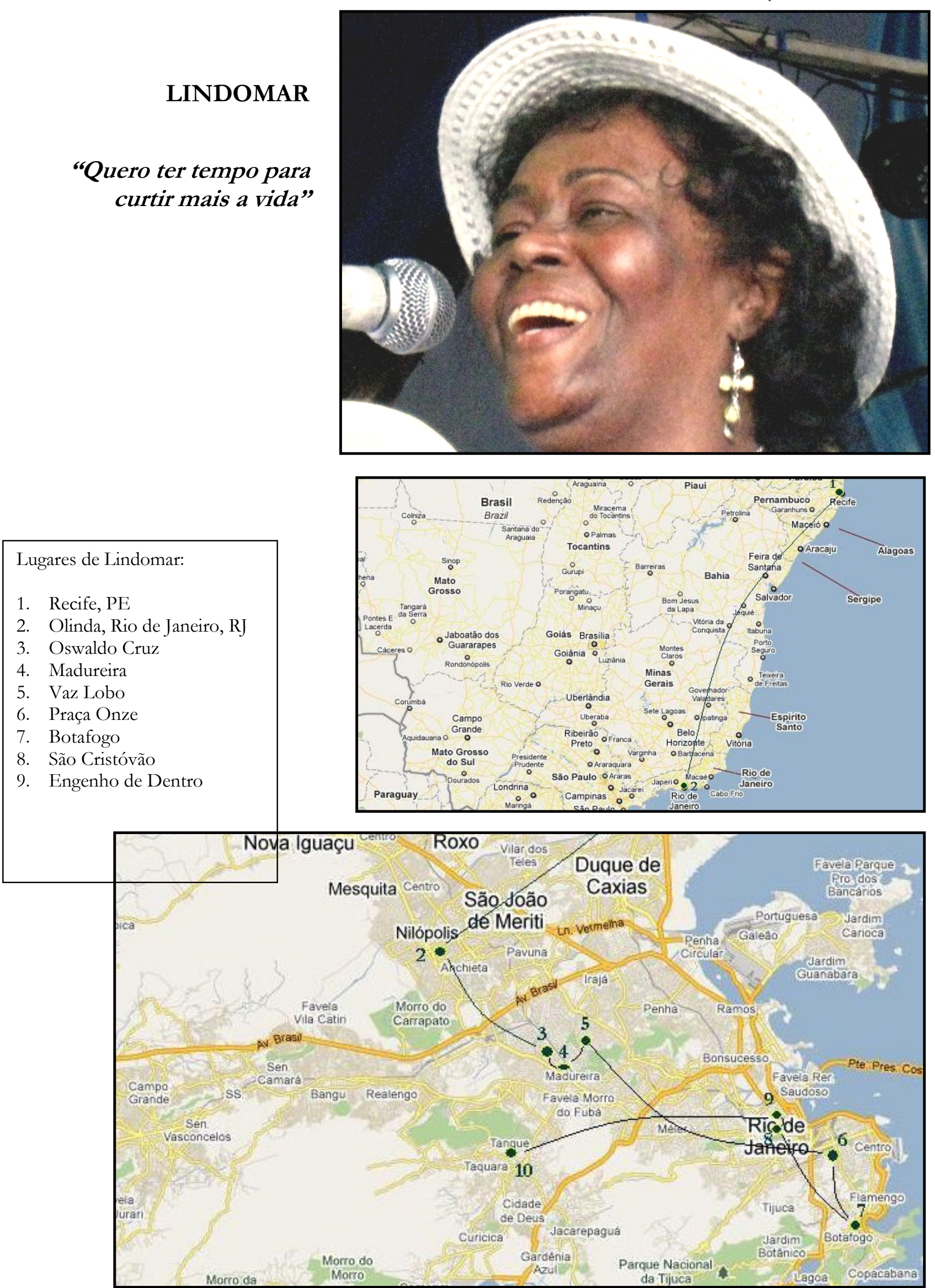
Meu nome é Lindomar Ferreira Fraga, nasci em 17 de fevereiro de 1941, em Recife, Pernambuco. Sempre fui costureira, modelista, estilista, idealista... Sempre estive na costura, desde os 6 anos de idade. Minha infância foi ótima: eu era muito mimada por toda a minha família. Minha avó, meu pai, minha mãe, todos me mimavam, porque eu era uma criança que não tinha muita saúde, o médico dizia que eu não ia passar dos 10 anos. Agora, aos 70, eu acho que ele esqueceu um zero.

Ah, porque minha família toda achava que eu não ia sobreviver, que o médico me desenganou. Eu tinha um problema de sinusite. E sei que foi passando, passando, e eu estou aqui até hoje, e a sinusite também não me atrapalha mais. Minha sobrinha, que é bem mais nova que eu, filha da minha irmã, nasceu também com sinusite e já operou duas vezes, mas graças a Deus eu nunca precisei operar, e vou vivendo.

Graças a Deus, tenho saúde. Quero continuar fazendo o que eu sempre fiz, a minha vida toda: brincando, rindo, cantando, com bons amigos, curtindo a minha mãe, que está com 92 anos... Curtindo muito a minha mãe, que todos os dias de manhã eu dou o remedinho dela, antes de sair, e qualquer lugar que eu vá, primeiro a minha mãe, porque essa é única. Eu acho que quem tem sua mãe tem que fazer tudo, até se puder carregar no colo, carregar. Ela mora aqui, na casa de baixo. Sou a segunda de sete irmãos, mas uma se foi, porque chegou a hora... Agora, comigo são seis.

E tenho meu companheiro, que agora está meio adoentadinho, também não me proíbe de nada... Eu viajo, eu vou ao samba, eu vou para o Império, vou fazer show, é só avisar.

- Que horas que você vai chegar?

- Olha, eu só sei a hora que eu estou saindo, hora de chegar...

E vamos vivendo. E tem também meu trabalho, que é a minha vida inteira, desde os 11 anos. Comecei a costurar com 6 anos; com 11 anos eu me formei em Corte e Costura, lá na Paróquia São Mateus de Oswaldo Cruz, na escola que tinha lá, na Rua Pinto Campos. De lá para cá não parei mais, até hoje, e vamos vivendo a vida. Quando tem uma chancezinha, eu vou dar um passeio, arejar a cabeça, que faz parte.

Eu vim de Recife em 1951 para 1952, e logo depois morreu o Chico Viola, Francisco Alves. Quando ele morreu, eu já estava morando em Oswaldo Cruz. Eu cheguei aqui no dia 13 de junho, dia de Santo Antônio. Aí, logo depois, em setembro, aconteceu aquele acidente com ele... Freqüentei muito a Rádio Nacional, a Rádio Tupi, era macaca de auditório, daqueles meninos todos, do Luiz Vieira, Paulo Bob, eu gostava muito da Marlene, e as minhas primas gostavam da Emilinha. Não brigávamos, não.

Então tinha o Cine Madureira, o Cine Alfa, o Cine Coliseu, nós íamos muito ao cinema, onde eles vinham fazer show, na matinê, pela manhã. Até o meio-dia, eles vinham para ali cantar, então aquilo ali ficava com aquela garotada, que hoje eu vejo esses negócios de funk, e me lembro muito... Cada um tem a sua idade, não é? E no nosso tempo era isso. Teve uma vez, quando eu morava em Oswaldo Cruz, tinha um circo, até quase em frente a onde o Zé Luiz mora, eu morava na Rua Pinto Campos e pedi à minha mãe para assistir ao show do Circo. E chegou quem? Paulo Bob, Nora Ney, Jorge Goulart... Nós éramos muito amigos do Paulo Bob. Ele, quando chegou:

- Não, vamos entrar, vamos entrar... 
- Não, nós viemos só ver a sua chegada.

- Não, entra, entra!

Nós entramos. Ah, pra quê. Assistimos ao show; quando chegamos em casa, minha mãe já sabia que nós estávamos lá dentro do circo. Eu e minhas duas irmãs levamos uma surra! E o nosso colega, que foi nos acompanhando, que morava na rua:

- Eu vou ficar sentado aqui, para escutar vocês gritando.

E eu não gritei! Minhas duas irmãs gritaram e eu não gritei, fiquei chorando, assim, baixinho, prendendo o choro, para ele não escutar.

Estava com 12 para 13 anos. Depois continuei freqüentando, até hoje eu escuto a Rádio Nacional, Rádio Tupi. O Império também estava na fita, mas era só quando minha tia me levava. Assim que eu cheguei de Recife, com 11 anos, fui para o Império. Era lá em cima. Lembro que era numa casa na Serrinha, a casa da Tia Eulália. Aí, às vezes, quando minha tia ia pra lá, eu ia junto. Era um terreno grande, chovia, e a gente subindo aquele morro e a água descendo.

Naquela época, no desfile, só tinha aquela corda cercando, então minha tia fazia uma ala para a gente, umas roupas verde e branco, que nós vínhamos encerrando a escola, ali no final. Depois foi lá para a Presidente Vargas, era aquele tablado, desfilava ali, depois descia. Depois foi para a Candelária, na Avenida Presidente Antonio Carlos. Eu lembro que teve um ano que o enredo era Dona Santa, rainha do maracatu, que foi ali, e teve outro ano na Antonio Carlos e nós ficamos todos sujos, porque tinha aqueles banheiros que não eram bem banheiros químicos, porque os negócios saíam pela rua... Olha, mas sujava todo mundo! Teve outro ano, isso já foi bem para cá, o ano do Oscarito, carnaval e samba, uma chanchada no asfalto que nós desfilamos ali no Catumbi, e a nossa concentração foi dentro do Túnel Martins de Sá. 1978 foi o ano em que Oscarito nos enterrou, também, quando o Império desceu, e na nossa frente, quem veio? A Ilha do Governador. Depois disso eu me casei e me afastei um pouco da escola.

Não tive filhos. Fiquei grávida três vezes, todas as três vezes foi de gêmeos, então engravidei de seis filhos, mas Deus não quis. A última que eu perdi foi um casal, eu estava com cinco meses. Até hoje eu tenho as roupinhas deles guardadas. $\mathrm{Eu}$ estava enorme, baixinha, bem gordinha, parecia uma bolinha. E continuo vivendo, enquanto Deus permitir, freqüentando o Império, freqüentando a nossa Velha Guarda. Porque chega a hora e Ele fala assim:

- Chega, tu já curtiu muito.

É, curti o Império bastante tempo, só dei uma parada quando me casei, porque com o meu primeiro marido não podia nem olhar pro lado: eu tinha 19 anos e ele 34 . Esse agora já é o segundo casamento, que eu sou viúva. Mas com o primeiro não podia nem falar em samba, não! Porque a mulher, naquela época em que eu casei, em 1961, a mulher não usava calça comprida, não raspava a sobrancelha, tinha que ser do lar. Mulher não podia trabalhar fora e eu já trabalhava na Avenida Marechal Floriano, no Centro, depois fui trabalhar na Rua do Rosário.

Sempre trabalhei em costura. Eu tomava conta de toda a fábrica. Depois fui trabalhar em Copacabana, quando a firma mudou para lá, mas sempre freqüentando o Império também. Não podia deixar meu Império. Depois, aí, eu fui trabalhar na Rua Antunes Maciel, em São Cristóvão, quando já estava morando em São Cristóvão. 
Ali eu trabalhei bastante tempo, tomava conta de 148 empregados, entre passadeiras, overloquistas, costureiras, acabadeiras... Porque tem a marcadeira e tem acabadeira. As pessoas acham que é a mesma coisa, mas não é: a acabadeira faz bainha, prega botão; a arrematadeira corta linhas, tira todo aquele apare, entendeu? Então eu tomava conta de toda a parte de corte, cortador, modelista... Nessa época eu não desenhava, eu costurava na minha casa, mas lá eu tomava conta, só. Como dizem que chefe é de índio, não é? Eu fazia parte da chefia, mas era muito bom. Os patrões gostavam muito de mim, me davam todo o apoio, o que eu dissesse ali dentro da firma era lei. Muito bom mesmo.

Mas eu já participava de ala, desde o início. Lembro do tempo do Fernando Pinto, em que nós saímos de índio, o enredo era Viagem encantada Pindorama adentro, várias coisas. Eu era baixinha, gordinha, bonitinha, ah, quando eu me lembro daquele corpinho, ha-ha! Que saudades... E teve também o de 1975, que era Zaquia Jorge, vedete do subúrbio, estrela de madureira e a nossa ala foi a ala do Palco Iluminado, então para as mulheres era biquíni, bustiezinho, e uma capa cheia de estrelas presa nos dedos, que fui eu que fiz, também, nessa época. No desfile de Pindorama adentro, em 1973, minha sobrinha foi a primeira porta-bandeira mirim, que muita gente não lembra, diz que não é verdade, mas tem a prova aí, que eu fiz a roupa dela e do mestre-sala. Foi toda de folhagem. Aquelas folhas recortadas, bordadas de paetê e aplicadas, a roupa todinha da porta-bandeira e a calça do mestre-sala - uma calça até abaixo do joelho, o meião e aquela casaca. Quer dizer, eu tento fazer, e tento curtir a minha vida, trabalhando, porque acho que isso faz parte da vida, não é?

Teve uma época em que meu irmão, Genival, era presidente da ala Mocidade Imperial. Aí depois ele casou e, por ciúmes da esposa, deixou a ala. Eu então peguei a ala e continuei, e fiquei com a ala Mocidade Imperial por mais de 10 anos. Teve $O$ mundo dos sonhos de Beto Carrero, teve Lampião e Maria Bonita... E eu fazia as roupas, também. Tinha componentes, eu organizava as reuniões, tinha que participar de ensaios, ter as camisetas para a hora do ensaio, tudo bonitinho, organizado. Eram 150 componentes. Depois a Neide dividiu a ala por dois, daria 75 componentes para cada presidente, que era o que se dizia ala grupada. E eu continuei com a ala.

Para a Velha Guarda eu entrei no ano de 1999 para 2000, quando o mestre Campolino me convidou. E eu dizendo que não, que não tinha tempo, mas ele:

- Não, você vai! Se você não for, mais a Nina, então não vai ter Velha Guarda.

Aí eu fui, convidada também pela Neide, que naquela época já era presidente, e o Valdeci, que era lá da diretoria da Neide.

- Ah, vamos.

Aí fomos, eu e tia Nina. Nós íamos muito a ensaio, à Rádio Nacional. Era muito engraçado, quando nós começamos... Para tirar carteira da Ordem dos Músicos, saía correndo Campolino, com as pernas compridas! Ia na frente, eu no meio, correndo atrás dele, porque as outras duas - tia Nina e Nini - andavam mais devagar, e eu tinha que saber por onde é que ele ia entrar, qual era a rua onde ele ia. Eu dava uma parada, chamava, olhava para trás...

Depois que a Nini se afastou, aí foi que veio a Balbina. Ela não está desde o início, mas é neta da Tia Eulália, então a Neide achou que ela devia entrar, porque ela viveu a vida toda - toda não, porque ela foi do colégio interno, conforme ela diz, que eu também nem sabia, e não ficava direto na escola, depois que ela saiu do colégio 
interno que ela participou mais. Então ficou muito conhecida, porque ela é muito assim, muito alegre, uma pessoa assim... Então Portela, Império, todo mundo conhece ela. Tanto que as pessoas acham que ninguém me conhece, eu também... Porque eu fico, você vê, na minha casa, aqui dentro. Vou ao Império, fui no domingo, que teve eleição, quer dizer, as pessoas não me vêem muito. Quem me conhece há muitos anos sabe quem eu sou, mas não que eu viva dentro do Império. Mas fiquei na Velha Guarda, e sempre que tem reunião estou, nunca faltei, a não ser em caso de doença. Quando tem apresentação, show, ensaio, eu estou, não falto, não posso faltar... Fecho tudo, digo às minhas meninas:

- Olha, amanhã você não vem.

Para não ficarem sozinhas, que eu não gosto. Atualmente, tem duas trabalhando aqui, mas eu já tive mais de dez aqui dentro de casa. Agora eu estou trabalhando menos, a gente vai ficando mais velha, aí eu acho que vai perdendo a vontade. Você chegava aqui em casa com uma bolsa de tecido; quando saía, já saía com a roupa toda pronta. Era, eu tinha uma amiga que dizia que era minha afilhada, a Meire, ela ia à loja de tecido, trazia a bolsa:

- Ai, minha madrinha, eu quero essas roupas para hoje, que eu vou viajar amanhã.

Ela chegava assim, mais ou menos uma hora, uma e meia, que ela sabe que meio-dia eu paro para almoçar, pego uma hora. Aí nós ficávamos até meia-noite, uma hora da manhã, ela levava toda a roupa! E não era assim, um conjunto, não. Era blazer com saia, blazer com calça, era muita roupa. Hoje eu fico imaginando como eu fazia aquilo tudo, e sozinha. Porque nesse caso, as meninas não me ajudavam. Com roupa de freguês eu não gosto que me ajudem, porque eu boto defeito em tudo. Sou muito perfeccionista, aí eu já sentava na máquina desmanchando alguma coisinha que não tinha me agradado.

Quando eu era criança, eu adorava cantar. Cantava no circo, cantava no parque, porque tinha aquelas garotas:

- Ah, vamos cantar?

E eu estava sempre cantando. Cantava, deixa eu ver, assim:

Hoje não te quero mais

Eu preciso de paz

Já cansei de sofrer

Vives na rua jogado

És um fósforo queimado

Atirado no chão

Tu para mim és ninguém

Procure um outro alguém

Que te ajude a viver

Pouco importa

Se sofres assim

zombaste de mim

Precisas sofrer

Em vez de tentares a sorte

Procuras a morte

És a gorjeta deixada

Em um botequim 


\section{Foste cruel para mim}

Não te lembras agora

Hoje não me interessa

Se sofres assim

Ah, muitas coisas! Isso já era aqui no Rio. Eu gostava muito da música da Nora Ney, Ângela Maria, Alcione, sempre cantava, assim, mas não era profissional. Aí depois nós fomos lá, para a Ordem dos Músicos, fizemos um ensaio, isso já na Velha Guarda musical, porque para tirar a carteira tem que fazer o teste, se não, não tira. Aí eu fiz o teste, passei e me deram a carteirinha. No Império eu cantava, assim, no meio do povão; no palco não.

Tenho a carteira da Ordem dos Músicos e também... Passaporte. O samba me ajudou muito, não só na Velha Guarda, porque no samba nós temos muitas oportunidades de conhecer lugares onde o pessoal comum não vai. Por exemplo, fui a teatros, fui a shows, convidada, assim... Porque o pobre mesmo não anda em determinados lugares, a não ser que seja convidado. Então com o samba, a gente vai, determinadas pessoas, se separa aquele grupo, então vai.

Estou indo sempre a São Paulo, no SESC, que eu adoro. Fui ao SESC Pinheiros, logo depois que houve aquele acidente com o metrô, e quando nós estávamos cantando, terminamos de cantar, entrou a Dona Ivone Lara e foi uma falta de sorte nossa, que naquele momento um carro - guindaste, parece - bateu no fio de alta tensão e teve um apagão em São Paulo. Nós estávamos lá embaixo, não sei quantos andares abaixo do solo, que é o teatro do SESC Pinheiros... Estivemos umas três ou quatro vezes no SESC Pompéia, em vários. Onde mais? Três Rios, eu acho que já fui umas três vezes, ou quatro, e outros lugares também. E se eu estivesse em casa, não teria ido a lugar nenhum, ia daqui lá para o mercado... Vida de dona de casa, a pessoa diz que nunca tem tempo para nada, mas nós é que fazemos o nosso tempo. $\mathrm{E}$ eu quero ter tempo para curtir mais a vida, com 70 anos, mas estou achando que ainda não curti nem metade do que eu tenho direito.

Gosto de cantar, mas não penso em cantar sozinha. Só com a Velha Guarda, penso em cantar sempre junto com eles, e continuar com minha vida, porque eu estou com a carteira da Ordem dos Músicos, mas não sou uma artista. Eu faço parte de um grupo. E todo grupo tem que ter consciência de que aquilo ali é um elo. Aquela rodinha, fora do elo, não é nada. A não ser que a pessoa se proponha alguma coisa. Se a pessoa não tiver outra vida, outra situação. Porque a minha vida é aqui, é a costura. Como o Zé Luiz que é compositor, cantor, ele agora está fazendo a carreira dele solo, que eu acho lindo isso, o Wilson das Neves também, quem mais? Aluizio Machado, Ivan Milanez. Mas eu não tenho essa... Só se Deus permitir. A nossa vida muda, assim, de uma hora para outra, então quem sabe?

Ah, o que eu mais gosto é a convivência com os companheiros, aquelas horas que a gente passa na van, aquela coisa, aquela ansiedade:

- Ah, vamos encontrar tal hora, tal dia.

- Olha, você não chega atrasado!

Quando chega atrasado, um abre o braço:

- Por que é que está abrindo o braço?

Não temos lugar certo para ensaiar. O primeiro ensaio, de fotos e de canto, foi na casa do Cizinho, em Vaz Lobo. Tem umas fotos muito bonitas, não sei se o Zé Luiz tem. Foi muito bonito, com Mestre Campolino, que ainda estava vivo... Ele ainda 
durou um pouquinho. Chegou a participar, quando nos apresentamos no Espaço Cultural Sérgio Porto, na Rádio Nacional, na casa do Cizinho e outros lugares em que nós passamos. Ele ficou um ano e pouco, não deu nem dois anos, que o moço maior, lá de cima... Chegou a hora dele e ele foi chamado. Então eu gosto mais dessa parte assim, do ensaio, aquela parte do encontro, e vamos com que roupa, aquela música:

Com que roupa eu vou

Ao samba que você me convidou...

É isso, na Velha Guarda tem que estar todo mundo impecável, chega todo mundo desarrumado, e aí é o que eu chamo que chegou a hora do transformista. Chega todo mundo de qualquer maneira; daqui a pouco, está todo mundo impecável, para se apresentar. Eu acho isso muito bacana.

Eu gosto muito de cantar samba-enredo. Gosto de cantar aquela música:

Vem, vem ouvir!

O Império tocou, reunir

Vem, vem ouvir!

O Império tocou, reunir

(Não fique assim)

Não fique assim desanimada

Seu amor vai dizer

Que você é uma louca apaixonada...

Muito linda. Tem aquela, que nós não botamos no disco, Baleiro-bala.

Baleiro-bala

Grita o menino assim

Da Central a Madureira

É pregão até o fim

Baleiro-bala...

Acho bonito isso também. Aquela Zaquia Jorge, acho linda, também, e as músicas do Roberto Ribeiro, que são uma coisa espetacular. Tem essa, Menino de 47, que é linda, maravilhosa. Olha, o Império teve - não tem, mas teve - uma safra de sambas muito bons, quer dizer, era uma das escolas que tinha os sambas mais bonitos. Não é porque eu sou imperiana que eu falo; isso é dito por várias e várias pessoas, que agora eles não fazem mais daqueles sambas tão lindos, conforme se fizeram.

Eu acho que o jovem hoje tem outra cabeça. Porque os sambas, a maioria dos sambas do Império Serrano, eles reviviam muito a História do Brasil. Conforme mesmo a Balbina cita, muitas vezes ela ganhou 10 na escola porque ela começava a lembrar dos sambas do Império, porque contava a História do Brasil... Tem um samba do Aluizio Machado, não sei se eu vou lembrar dele agora...

Até as estações do ano

Já perderam seu valor

Primavera no outono

E faz frio no calor

Até as estações do ano

Já perderam seu valor

Primavera no outono

E faz frio no calor

Tem muito mais 


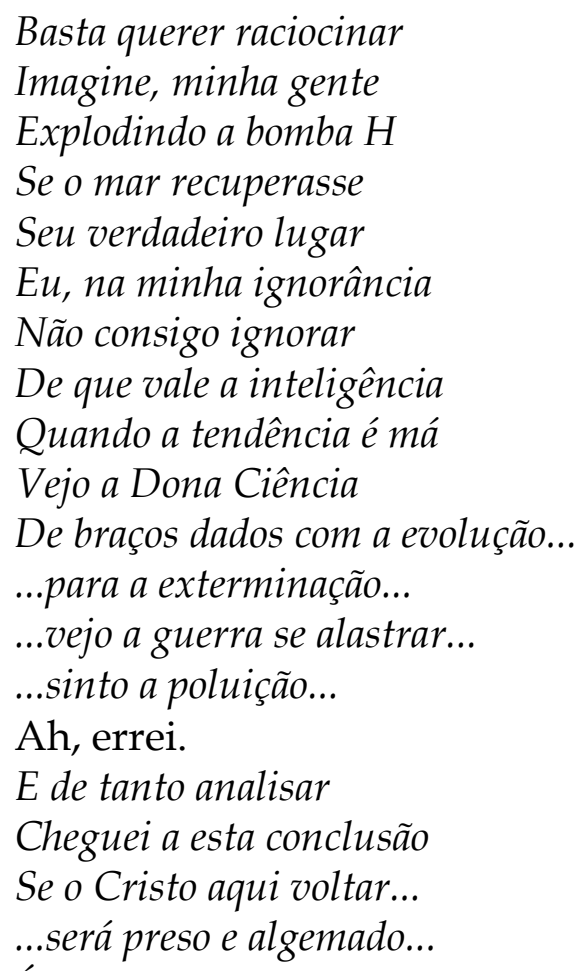

É mais ou menos isso. Então, esse samba, ele já fez tem muito tempo, e é o que está acontecendo hoje. Nós não sabemos quando é inverno, quando é verão; não sabemos quando é outono, não sabemos quando é primavera. Está uma confusão... Não é isso que está acontecendo? E esse samba vem falando disso tudo.

Eu não fazia parte da velha guarda da escola, apesar de que eu me dou com todos eles, porque eu conheço, do Império Serrano; não conheço de conviver na casa. Mas Campolino me convidou, porque eu fazia parte do Departamento Feminino, Departamento Social, mas não do departamento musical, que não tinha, entendeu? Só tinha velha guarda do Império, que as pessoas que estão fora dizem que Império é a única escola que tem três velhas guardas: velha guarda da escola, ala dos Cabelos Brancos e ala musical. Mas no fim é uma coisa só, é Império Serrano.

A velha guarda tem presidente, secretários, tudo ali dentro do grupo deles. Promovem atividades, eles visitam muito as escolas, se reúnem, tem a Associação das Velhas Guardas. E eles se encontram, todo domingo tem evento. É impressionante, porque inclusive eu trabalhei para a velha guarda do Império e atualmente estou trabalhando para a da Renascer de Jacarepaguá. Então elas chegam aqui correndo, querem roupa, porque tem uma saída para ir à escola tal, mas é todo domingo e sábado. Eu digo:

- Gente, não sei como é que vocês agüentam tanta cerveja!

Mas bebem muito. É bom, porque é uma idade em que as pessoas pensam que a pessoa está no final e realmente não está. A pessoa está continuando, vivendo, é como agora, que eu escutei falar que é a melhor idade, e realmente. É uma idade que não tem compromisso de casa, de marido, tudo aquilo. É um compromisso com ela mesma, com o samba, e não é só mulher, tem homem e mulher. Às vezes é o casal que vai, estão casados, ou vivem juntos há muitos anos, e estão juntinhos ali, vivendo a vida. E eu acho isso muito bonito.

Olha, eu acho que as pessoas discriminam muito o Império Serrano. É uma escola que, quem é Império, é Império mesmo. E quem não é, gosta de outra escola, 
tem o Império como segunda escola. Então nós temos consciência disso, todos os imperianos têm consciência disso. Tem pessoas que gostam do Império, porque o Império Serrano é uma família. Se você chegar lá, você vai se juntar, vai se reunir com a gente, parece que você já conhece todo mundo ali há muitos anos, ao passo que você chega em outra escola de samba, você fica, assim, reservada, e passa. Ali você está dentro de casa, você chega e está à vontade, vai para cá, vai para lá, aí uma te conhece, apresenta. Eu, quando levo alguém, todo mundo que passa:

- Ah, essa aqui é fulana, é minha colega, é minha amiga...

E fica, para se unir, para juntar ali, que é para a pessoa gostar. Eu faço sempre assim, não só eu, como outras pessoas também.

E vou ainda, domingo mesmo eu fui votar... Essa eleição agora, do Império, foi assim, tapa-buraco. Porque o que é que aconteceu? O Presidente renunciou. Nós estamos em cima do carnaval, temos que fazer tudo correndo. Quando eu digo "nós", são eles, que eu posso ajudar em alguma coisa, mas eu não vivo lá dentro do Império. Então teve essa eleição tapa-buraco e, dependendo do que esse presidente agora fizer... Porque em junho ou julho vai ter outra eleição, depois do carnaval. Aí virão outros candidatos e esse candidato vai poder se reeleger.

O outro candidato era o neto da Tia Eulália, o Helton. Eu votei e saí, mas soube que a contagem de votos foi pau a pau. Eles encerraram com 204 votos cada um, todos os dois. Quer dizer, foi uma zebra... Aí o que é que aconteceu? A Vera, que o esposo dela já foi presidente do Império, há muitos anos - não estou lembrada o nome dele - e ela freqüenta também, há muitos anos, ela foi eleita, por quê? Porque ela era mais antiga que o neto da Tia Eulália, que é um rapaz novo. Mas ele tinha boas pessoas por trás dele também, carnavalesco e tudo, mas ficou a Vera, que como é mulher, vamos dar um voto de confiança, porque o importante nisso tudo é o Império. Mas eles também fizeram um acordo: quem ganhasse ia ajudar o outro. Entendeu?

Porque o quê que se quer ali dentro, agora? Que o Império volte para o Grupo Especial. Eu estou achando um pouquinho difícil, mas estou rezando para que aconteça, ele volte para o lugar dele. Olha, eu acho que a escola desceu porque as pessoas, ali, no Império, não querem se juntar, porque a Serrinha, o Cajueiro, o Cais do Porto, o pessoal dali, da Resistência, não aceita ninguém de fora. Eu acho que a pessoa para ter uma ajuda tem que ter alguém de fora, com força, com dinheiro, que o que manda agora é o dinheiro. Aí as pessoas dizem que nem é tanto dinheiro, que a Vila Isabel ganhou o Carnaval, com aquele carnaval bem pobre, não é? E o Império veio muito bem este ano, muito bem. Agora, para ficar em $6^{\circ}$ lugar no Grupo de Acesso, isso não foi justo. Nós entramos na avenida com garra, estávamos muito bem. Tinha defeito? Tinha, quem que não tem? Mas acontece que, como é Império Serrano, eles botam defeito maior. Isso entristece, eu acho que foi por isso que o Presidente se cansou. Ele estava há seis para sete anos, já estava na segunda gestão. Fez quatro, depois entrou com mais quatro, porque ganhou, foi reeleito.

A desavença entre escola de samba? Império, Portela, Salgueiro, Mangueira, as Velhas Guardas que trabalham juntas - que às vezes nós fazemos show todas juntas - é abraço, é beijo, aquela amizade, sabe? O negócio é lá na avenida, ha-ha! Na avenida é que é a disputa mesmo, mas mesmo assim, se encontra, se fala, freqüenta 
uma a casa da outra, eu é que não tenho tempo. Só assim, coisa muito... Aí eu saio, mas fazer visitinha é difícil.

Trabalho o dia inteiro, dia e noite. Faço desde a capa do colchão até o vestido de noiva. O que chegar aqui para eu fazer, eu faço. Agora eu trabalho para uma clínica, que vai ser inaugurada em Botafogo, trabalhava para a Ordem dos Advogados, trabalhei muitos anos, fazendo toda a roupa do CAARJ (Caixa de Assistência dos Advogados do Rio de Janeiro), centro médico, administração, tudo. Não só daqui, do Rio, como de fora - Petrópolis, São Paulo, Brasília, Recife, esses lugares todos. Vinham as medidas e algumas meninas vinham para a sede, que é no Castelo, nós íamos, meu irmão tira medida delas, e nós confeccionamos e mandamos. Isso é terno de segurança, terno dos meninos que trabalham lá na Secretaria, faço tudo, calça social, camisa social, paletó, o que vier, o negócio é trabalhar. 

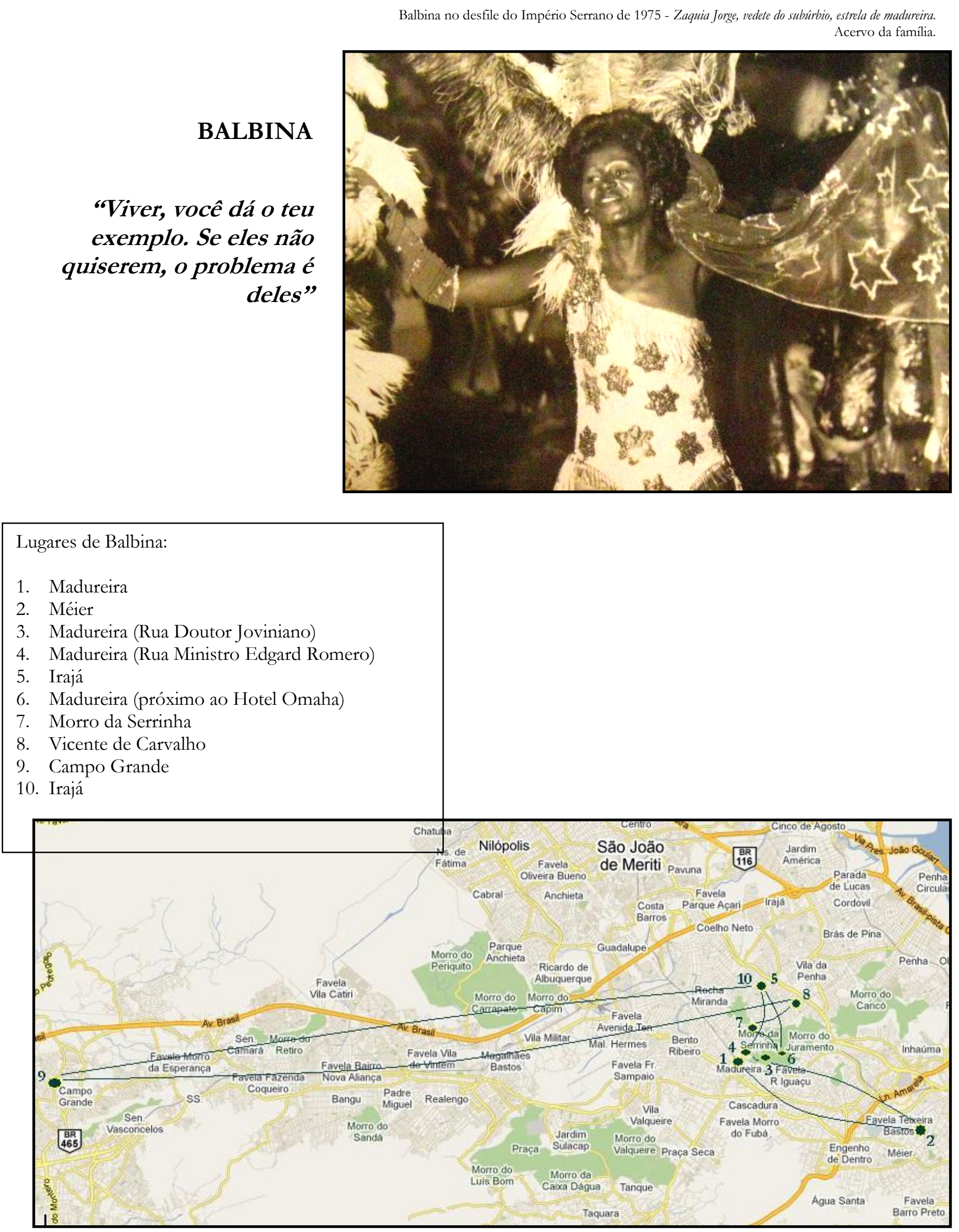
Eu sou Balbina de Oliveira Thomé e estou com 73 anos. Tenho orgulho de dizer a minha idade, porque chegar a 73 anos trabalhando, como eu trabalhei, é uma glória. Minha mãe não chegou, ela não passou dos 30 e poucos; meu pai também morreu cedo.

Fui criada no Asilo Infantil Nossa Senhora de Pompéia, um colégio de freiras, na Rua Cirne Maia, no Méier, um bairro que eu adoro, porque ali foi a minha infância. Nasci em Madureira, mas fui para o Méier com 5 anos de idade, que meu pai tinha falecido, e meu avô, como era uma pessoa conhecida na sociedade carioca, no Distrito Federal... Era próximo das famílias do Desembargador Mário Piragibe e Peixoto de Castro, famílias ilustres, que eram. Eu era afilhada da neta do doutor Peixoto de Castro, e esse colégio de freiras, de que eles eram os benfeitores, era para as crianças necessitadas, que não tinham seus pais, ou que não tinham possibilidades. Senti tristeza, porque eu queria estar com meus primos, mas foi bom. Hoje, tenho a responsabilidade que as freiras me deram; minha mãe tinha que trabalhar, então foi ali que eu aprendi. Mas a minha família, aqui fora também, me dava assistência - uns, não é? - e ia visitar.

Eu fui mandada para o colégio das freiras junto com minhas irmãs Gina Higina - e Marina, que mora em São Paulo. Eu digo sempre que São Paulo, pra minha irmã Marina, foi uma grande coisa. Quando ela saiu do colégio das freiras, foi para a mansão da minha madrinha na Praça da Bandeira, na Rua Santa Amélia, e estudou mais um bocadinho... Depois foi para São Paulo, Guarulhos, com uma amiga. Aqui no Rio ela não tinha dado sorte, mas ela era muito inteligente, então fez prova para a Justiça do Estado de São Paulo e passou. Ficou trabalhando lá, se casou, comprou casa, fez a vida dela lá, se aposentou. Eu gosto de São Paulo, eu vou sempre fazer show lá, com a Velha Guarda show, e eles morrem de rir:

- Olha ela com a bengala!

E eu fiquei no colégio interno, junto com a minha outra irmã. Nós estudamos bastante, porque no colégio de freira, você só passava se soubesse! O nosso primário foi muito bom. Ah, mas eu ficava doida quando se falava no Império Serrano, lá no colégio... Mas a gente não podia nem olhar, negócio de samba, porque era religioso, católico, não é? Eu ainda novinha, com 10 anos, não podia desfilar, porque antigamente criança não desfilava. Os pais levavam para ver os desfiles, levavam farofa, botava colchão, esperando a escola de samba desfilar, e as crianças comendo farofa. Os farofeiros, chamavam. Os pais, os mais velhos, segurando as crianças, e as crianças querendo ir. Só depois é que veio a autorização do Juizado de Menores, mas tinha que ter documento, tudo direitinho. Quando eu fiz 14 anos é que eu pude sair, quando saí do colégio interno, com o primário completo. Ah, eu disse:

- Eu vou sair!

Aí minha tia:

- Não, vai sair juntinho com elas, com as mais velhas!

Não saía como mocinha, sem juízo, não. Minhas tias mais velhas arrumaram minha roupa, e saí. Meu primeiro desfile foi em 1952, que eu saí do colégio e já era carnaval. O enredo homenageava Ana Néri. Estava toda feliz, nunca tinha saído! Mas era aquele temporal desesperado! Nós não desfilávamos assim, como hoje; era no tablado, uma passarela de madeira, que ficava ali perto da Praça XV, na Presidente 
Vargas, por ali. Era de madeira, não era esse carnaval não, os jovens têm que saber disso, respeitar as pessoas mais velhas que sofreram. Não tinha corda, aí o povo invadia as escolas de samba - a polícia vinha com aqueles cavalos, era a polícia cavalariça. Os policiais metiam o cavalo e o pessoal corria pra trás! E quando a polícia saía, o pessoal, pra ver a escola, corria na frente! A gente sofria, no carnaval, sofria! E o tablado assim, a gente subindo, cantando, e lembro de umas casinholas onde a comissão julgadora ficava.

O Império Serrano é filho do Prazer da Serrinha, que era a primeira escola de samba da Serrinha, em Madureira. Houve uma desavença no Prazer da Serrinha, que era uma boa escola, e a família Oliveira, que é a minha, foi uma das primeiras, com a família Santos e outras, de estivadores do Sindicato do Cais do Porto, que se reuniram e fundaram o Império Serrano. O primeiro presidente, João de Oliveira, João Gradim, era meu tio, irmão do meu pai. Eulália Nascimento de Oliveira, a Tia Eulália que faleceu, que todos conheceram, era minha tia. Antonio Fuleiro, mestre Fuleiro, era da família Santos. Essas, mais a família Feliciano, se juntaram ali na Serrinha. Eu tinha 10 anos, ainda estava no colégio de freiras.

Mas antigamente... Uma coisa que as pessoas jovens têm que saber é que o Brasil ainda não era desenvolvido quando eu nasci. O Brasil estava ainda se encaminhando pra o desenvolvimento, com Getúlio Vargas. Eu nasci na década de Getúlio Vargas, aquele grande presidente, que até hoje eu honro esse nome. No colégio interno eu estudava bem, porque antigamente não existia escola pública. Quem estudava, na época, eram pessoas de famílias que tinham um poder aquisitivo mais ou menos. O pobrezinho, como nós, que nascemos no morro, lá na Serrinha, não tinha escola pública, era só escola paga, e tinha muita em Madureira.

Nós estudávamos no que eu falo fundo de quintal, que tinha aquelas professoras, pobrezinhas, que davam aula para a gente na casa delas. Na Serrinha teve muita. Na Rua Itaúba, que hoje se chama Rua Mano Décio da Viola, tinha Dona Dulce, várias professoras de fundo de quintal, que davam aula para a gente aprender a ler. Mas na década de Getúlio Vargas, de 1930 para cá, foi que apareceram as escolas públicas, que todo pobre passou a estudar. Só não estudavam se não quisessem, ou se os pais não tivessem essa sabedoria.

No colégio a gente cantava muitas coisas, na igreja, e tinha que cantar bem, com órgão. O Império, em 1952, quando eu comecei a desfilar, eu novinha, com 14 pra 15 anos, magrinha - eu ainda sou magra, não é? E era mais ainda! - a gente subindo, cantando - e eu sempre gostei de cantar, por isso que eu sou da Velha Guarda show do Império. Eu sei que a gente ia subindo, cantando:

Ana Néri, corajosa enfermeira

A heroina brasileira

O ilustre professor

Doutor Oswaldo Cruz

Grande pesquisador

Carlos Chagas e Miguel Couto

Vulto de glórias mil

Na medicina do Brasil

Laureano, Caiado de Castro

Miguel Couto e outros mais

Ana Néri, corajosa enfermeira 


\section{A heroina brasileira... 52}

E eu toda de Ana Néri, aquela cruzinha vermelha. Mas o temporal! O temporal que caía - relâmpago, raio, trovoada! A gente na chuva, mas a gente cantando. O que é que houve? Anulou o Carnaval, foi anulado. Aí a guerra! Porque antigamente, as escolas de samba brigavam. Não era briga de pau. Entravam no tablado com amor, com gana de a escola ganhar. Não tinha nada que ninguém ganhasse dinheiro, não, não tinha dinheiro. Pra quê, que anulou o Carnaval? Portela e Império, eram as duas que tinham a quizumba! Mas a gente é amiga... É como futebol, a quizumba de Flamengo e Vasco - não brigava, mas ah, era aquilo! Portela desfilava em Madureira, a gente desfilava em Madureira, uma queria fazer melhor que a outra. Mas era bom, era um incentivo! Porque, se não tiver incentivo? Ih, você deixa tudo correr frouxo, como se diz na gíria. As duas eram boas. Quando o Império ganhava, a Portela fazia samba de deboche. Ha, ha! Era! Aí anulou o Carnaval e na Portela fizeram um samba pro Império!

Não foi Portela

Que anulou

Não foi Mangueira

Também não foi, não senhor

Esta escola

Para mim, é um mistério

Não digo o nome, deixo isso a seu critério...

Depois repetia:

Não foi Portela

Que anulou

Não foi Mangueira

Também não foi, não senhor

Esta escola fica perto de Madureira...53

Que a gente era entre Madureira e Vaz Lobo.

Saiu representando, em 52

Ana Néri

Ha, ha!

A corajosa enfermeira...

Aí o Império fez um samba. Noel Canelinha, que faleceu, era um dos melhores mestres-salas das escolas de samba. Ele e Joel, de Vaz Lobo, fizeram o samba. Eu:

- Como é que é que vocês vão fazer?

Eu mocinha, danadinha... Eles não debocharam, foram com potência, com educação. A Portela fez de deboche, mas o Império, Noel, fez naquela, devagar... Na moral. Ele fez aquele assim:

Nós não somos Jequitibá

Nem Peroba, nem Jacarandá

Nós podemos provar

Venha no Império Serrano e verás, vem apreciar

\footnotetext{
52 Optou-se ao validar esta transcriação, por corrigir as letras dos sambas citados por Balbina, já que eram pontuais. Nos casos em que ela não cantava o samba inteiro, foram reproduzidos apenas os versos cantados.

${ }^{53}$ Sérgio Cabral transcreveu a letra completa: "Não foi Portela / que anulou / não foi Mangueira / também não foi, não senhor / Essa escola / Pra vocês é um mistério / Não digo o nome / Deixo isso a seu critério / Mais uma chance eu vou lhe dar / Essa escola fica perto de Madureira / saiu representando em cinqüenta e dois / Ana Néri, a corajosa enfermeira". (1974, p. 124).
} 
Vem apreciar, e vais ver

O samba é com perfeição, podes crer

E cada uma fazia o samba para a outra! E depois, quando se encontravam... Então tinha aquela vontade, era amor, as escolas eram com amor... Agora não! Não me leve a mal, pode botar o que eu estou dizendo! Eu estava falando para a minha filha, estou ficando cansada disso. Porque você, para uma escola de samba desfilar, você já está bem sabendo quem é que vai ganhar, quais são as escolas que vão ganhar, que são as dos banqueiros de bicho! Eles se meteram, mas não existia banqueiro de bicho!

O samba era bom quando eles não existiam, essa briga que eles têm! E as pessoas que vão julgar, às vezes já estão sabendo. Se uma tira 5, elas já vão com aquele papel para tirar os décimos. Isso não adianta, não dá prazer de você ir para a avenida, brincar, sabendo que a escola que vai ganhar é a dos banqueiros de bicho.

Depois, no outro ano, foi $O$ último baile da Corte imperial, na Ilha Fiscal, ali na Marinha, na Praça XV. Tem gente que não sabe nem o que é Ilha Fiscal, eu sabia, que eu ia lá com a minha tia, ver, para fazer o enredo, de vez em quando passeava. Foi o segundo ano que eu saí no Império.

Foi o último baile

Do Brasil Imperial

Foi realizado

$\mathrm{Na}$ antiga Ilha Fiscal

Os ilustres visitantes homenageados

Partiram para seu país distante

Com êxito brilhante, emocionados

Sua Majestade, o Imperador

Ao lado da Imperatriz

Diante de tanto esplendor

Sentia-se alegre e feliz

Jamais acreditaria

Que o seu reinado terminaria

Que mesmo a Corte não pensando assim

A monarquia chegava ao fim

O pessoal dos Fuzileiros Navais, da Marinha, ficava... Aplaudia o Império, o Império era muito bonito! O Império foi a escola que veio para moralizar as escolas de samba, porque elas eram discriminadas. Foi a primeira escola de samba em que um presidente subiu, que foi Lutero Vargas, filho de Getúlio. Ouviu a gente cantando lá em cima, no alto do morro, aquilo bonito, ele subiu as escadas para ver, na Serrinha, na Rua Balaiada, onde eu nasci. Para ver. Porque era organizado, o Império era uma coisa muito organizada. Mulher, na quadra, ficava de um lado, homem de outro. Não tinha mistura. E minha tia gostava de ver a gente toda bem vestida. Se fosse com lencinho na cabeça, Mestre Fuleiro não deixava entrar na quadra. As mulheres todas bem calçadas.

O Império foi a gente que fez! Quando houve a união dos banqueiros de bicho todos, nas escolas de samba, isso era lavação de dinheiro! Foi na Ditadura, quando eles foram presos na Ilha Grande. Eu não sei como esse povo não se manca! Eles juntaram, aí botou uma tal de Liga, eu digo: eu?! Carnaval era muito bom nas escolas de samba, muito bom mesmo, mas eles acabaram com a graça das escolas de samba. 
A Portela também era boa, agora a gente fica aí, hã! Vai desfilar no Carnaval, já sabe quem vai ganhar: Beija-Flor. Eu conheci aquilo laranjal, aquilo tudo era granja. Em Nilópolis, a Beija-Flor ensaiava numa casa perto da linha do trem, de cerca, assim.

No ano em que morreu... Olha aqui, eu marco tanto, a minha mente, ela foge e não foge, eu tenho uma coisa assim, que a doutora disse:

- Quando ela fugir, você não aceita!

Lá, em Nilópolis, quando Francisco Alves morreu, em 1950 e poucos, não foi? Chico Viola, o rei da voz. Beija-Flor era nova, era escolinha. Eles não sabem, esses de agora, mas eu sei. Naquele tempo, que eu ia no trem, para lá, só tinha laranjal, boi... Beija-Flor não tinha nada, ainda era aquilo, assim, como Madureira também, tinha boi na linha do trem, laranjal, e eu ia lá para Nilópolis.

Eu tinha um avô de criação, português, dono daqueles gados todos. Era marido da minha avó, mãe da minha mãe, que era negra, uma cabocla, muito bonita, índia misturada com negro. Saiu aquela cabocla bonita. O português adorava a minha avó, Seu João. Seu João era dono daqueles gados, daquelas plantações todas, e a gente ia, minha irmã mais velha ia mais. Eu fui num grupo, com o Império, na minha ala, a ala das Caçulas, que foi a primeira em que eu saí - Helena e Ester eram as diretoras... E Liette, que ainda está viva, duas estão vivas. Nós fomos a convite dos compositores, para jogar o samba. Nem existia banqueiro, essa gente! Eu? Isso é com vocês, agora!

Ih, o trem era ruim, naquela época! Aquele trem ruim, aquela estação com uma casa antiga. Nilópolis. Nós fomos - a gente moça quer andar, não é? A gente gosta de andar. Chegamos lá, esse compositor que convidou a gente, era para a gente cantar o samba dele: eles convidam para cantar o samba na quadra para ajudar, para vencer o samba, mas a gente não era da escola. Aprendia e jogava o samba deles na quadra. E fomos, aquele trem que não vinha nunca! Ha-ha! Eu me lembro, nós chegando na quadra... Não esqueci o samba, não. Para você ver, coisa antiga eu não esqueço. A velhice, coisa antiga tu não esquece não, tu esquece a presente, a coisa mais presente. A velhice não esquece o passado não. Eu não esqueci nada. $\mathrm{O}$ samba deles era assim, porque quando o Francisco Alves morreu, ih, parou tudo, era uma novidade, flores. Aí o samba deles era assim:

Flores e mais flores

Gente em quantidade

Lágrimas sentidas

Eu vi derramar

Foi um quadro triste

Nunca visto outro igual

A terra cobria o corpo de Francisco Alves

O rei da voz, que chegava ao seu ponto final

A terra cobria o corpo de Francisco Alves

O rei da voz, que chegava ao seu ponto final

Ave Maria

Ave Maria

La-ra...

Esse pedacinho eu esqueci. Acho que foi em 1954, homenageando Francisco Alves.

A cidade inteira emudeceu 
Que da terra desaparecia

$\mathrm{Eu}$ ia ter cabeça para fazer um samba desses? Estou mentindo? Mas é, foi assim. E o Império era muito bonito. As alas no Império não deixavam ninguém ver as roupas, só via no dia, para ninguém copiar. Ih, nós ficávamos assim, todo mundo ficava esperando passar um de cada ala, para a gente ver a ala que era mais bonita, que elas caprichavam. O Império Serrano foi a primeira escola a botar prato e agogô. O prato era o falecido Calixto, João Calixto, que era Polícia Federal, marido da Olegária, que foi a primeira destaque, que mora na Ilha do Governador, ainda está aí, viva. O meu irmão veio, Caobi, que faleceu há muitos anos, mais velho... Ele veio como destaque de Peri e a Olegária de sinhazinha Ceci, por quem o Peri se apaixonou... O Guarani, me lembro bem, homenageando Peri e Ceci. Eu me lembro que o maestro Peruzzi, quando viu a gente, o Império com essa beleza, o samba bonito, um tipo de valsa, ele botou em valsa, ficou bonito à beça. Como era?

Homenageando

Ao derrotado Peri

Tendo lutado com a onça enfurecida

Pra ofertar a seu amor

Com risco da própria vida

Amor que nasceu sem vaidade

E seria levado pela tempestade

Procuramos homenagear

Olha a história!

A José de Alencar

Evocando seu passado de escritor

De ricas obras foi autor

Exaltamos o Guarani

Que é inspirado no amor de Peri

Pela fidalga Ceci

Que é inspirado no amor de Peri

Pela fidalga Ceci

Lá-lá-lalaiá

Lá-lalaiá

Lalaiá-laiáraiá

Assim Carlos Gomes, célebre maestro

Musicou O Guarani

Homenageando ao devotado Peri

Tendo lutado com a onça enfurecida

Pra ofertar a seu amor

Com risco da própria vida

E a gente dançando valsa.

Amor que nasceu sem vaidade

E seria levado pela tempestade...

Depois chegou Silas de Oliveira, que já era, também, fundador. O pai de Silas de Oliveira, Seu Assumpção, foi um dos primeiros professores de fundo de quintal na Serrinha, ele dava aula para as crianças, ensinava a aprender e a ler. Silas veio, naquele ano, 1964, com a... Que eu canto, que o pessoal pede:

- Balbina, canta! 
Aquarela brasileira. Antigamente não tinha gravadora para escola de samba, não tinha nada disso, a gente que cantava mesmo, no meio, eles traziam o papel para a gente ler. A gente, que tinha voz, que era conhecida deles, ficava com eles, no meio da quadra, jogando o samba para eles aprenderem. Era a falecida Elaine ${ }^{54}$, minha prima, mulher do Silas de Oliveira, que a minha família, as mulheres quase todas cantam, têm voz. A Elaine, esposa dele, eu, tia Eulália - ela era mais de idade, mas sempre teve harmonia na voz, ela tinha aquela voz boa, bonita -, a gente ficava cantando, com eles, a bateria baixinha para as pessoas aprenderem o samba, primeiro. Depois é que a bateria subia. Eu me lembro, Aquarela brasileira, era um samba grande, não é? Então era com papel. Como é? Está vendo a minha cabeça? A doutora manda puxar. É assim... Passeando, vastos seringais... Timbó...

Estava no Ceará, terra de Irapuã

De Iracema e Tupã

Fiquei radiante de alegria

Quando eu cheguei na Bahia

Bahia de Castro Alves, do acarajé

Das noites de magia do candomblé

Depois de atravessar as matas do Ipu

Assisti em Pernambuco

À festa do frevo e do maracatu

Brasília tem o seu destaque

$\mathrm{Na}$ arte, na beleza e arquitetura

Olha que cabeça!

Feitiço de garoa pela serra

São Paulo engrandece a nossa terra

Do Leste, por todo o Centro-Oeste

Era eu, e a mulher dele, e minha tia!

Tudo é belo e tem lindo matiz

O Rio dos sambas e batucadas

Dos malandros e mulatas

De requebros febris

Brasil, essas nossas verdes matas

Cachoeiras e cascatas

De colorido sutil

E este lindo céu azul anil

Emolduram em aquarela o meu Brasil

Lá-lalalaiá / lá-lalalaiá

Vejam, esta maravilha de cenário

Ele bebia...

É um episódio relicário

Mas tinha cabeça!

Que o artista, num sonho genial

Escolheu para este Carnaval

E o asfalto como passarela

Será a tela do Brasil em forma de aquarela

Passeando pelas cercanias do Amazonas

\footnotetext{
${ }^{54}$ Valença \& Valença (1981, p. 20) informam que o nome da mulher de Silas era Elane dos Santos.
} 


\section{Conheci vastos seringais}

E no Pará, a ilha de Marajó

E a velha cabana do Timbó...

Ah, bonito pra caramba! E ele bebia cachaça! Ele com a caixinha de fósforo, era ele e Mano Décio, mas aí já tinha polêmica, também. Porque os compositores, se são bons, querem um fazer melhor que o outro. Silas sempre foi humilde, muito humilde. Por isso, Deus deu essa grandeza a ele. E os outros que ficavam, era aquele despeito!

- Hmm, professor...

E eu:

- Professor mesmo!

Eu discutia.

- Professor mesmo, ele é o melhor!

Ha-ha! Tanto ala como compositor, tinha disputa. Porta-bandeira era Jacira, minha prima também, filha da minha tia Conceição. E essa não gostava de samba, minha tia Conceição nunca gostou, nunca foi. Era Jacira, Josélia, filha da tia Eulália, Irani, filha da prima da minha avó. Eram as três porta-bandeiras. Everaldo foi o primeiro mestre-sala, com Culinho, e o outro terceiro eu não lembro. Ih, o Império era muito bom, escola de samba era muito bom! E a gente lá, toda arrumada, bonitinha. Ah, e eu gostava:

Não foi Portela quem anulou...

Ha-ha! O Império foi bom, foi a escola que limpou, e aqueles estrangeiros que vinham para ver, subiam... E foi melhorando. Porque era uma bagunça, escola de samba! Eu tinha 10 anos, e o pessoal falava, os maridos não deixavam as mulheres saírem, não. Os maridos casados, as mulheres não saíam, eles não gostavam, só se saísse com eles. Assim mesmo, era aquilo. Porque antigamente a mulher não trabalhava fora, a mulher casada, o homem tirava logo, não podia trabalhar. Só quando elas tinham peito, mesmo. Mas o homem era assim. Agora não, que a mulher agora é "liberdade, liberdade, abra as asas sobre nós"! Ha-ha! Mas é, menina, e o Império está aí, nós estamos aí na luta, para ver o que é que vai dar, não é?

Fui trabalhar na Companhia Fiação do Rio de Janeiro, na Borborema, aos 14 anos, com carteira assinada, quando eu morava com meu tio, que foi quem me tirou do colégio interno. Mais tarde fui para o SENAI, na São Francisco Xavier, para o curso de Artes e Ofícios. Dali eu saí, me casei com 20 anos, Jussara nasceu. Casei, vim morar com minha sogra em Irajá, meus dois filhos já tinham nascido. Depois meu tio comprou uma casa, lá na Ministro Edgard Romero, na escadinha, em frente à Serrinha, descendo. Quando eu fui embora daqui, separada, meu marido morreu do coração. Jussara tinha 7, Jucemar, meu filho, tinha 5 pra 6. Enquanto eu estava lá, eu já não estava com as crianças, trabalhava em casa de família. Na casa da professora, em Ipanema. Aí fiz minha casa no alto do morro, na Serrinha mesmo, onde eu nasci. Fiz minha casa onde o Império Serrano tinha a quadra, no nosso terreno, da minha avó e do meu pai. A quadra do Império caiu, minhas tias fizeram a casa lá, para alugar, eu apanhei o pedaço que era do meu pai, fiz a minha casa.

Ali foi que eu fiz a prova para a Prefeitura, passei, fui trabalhar na Secretaria Municipal de Saúde. Graças ao colégio de freiras, eu e minhas irmãs aprendemos muito. Está aí: sou funcionária pública do município, fiz concurso, não entrei pela 
janela com vereador nenhum! Eu fui pro Maracanãzinho, sentei lá, na época que passou a ser Estado da Guanabara, com Carlos Lacerda, primeiro Governador, quando o Distrito Federal, capital da República, foi embora. Muita gente era federal, aqui, e foi para Brasília. Aqui ficou sem funcionário, então eles abriram o concurso, a inscrição. Eu fiz. Também, minha filha, corri atrás, que eu sou danada! Passei com nota boa, e tinha gente à beça com nota menor do que eu entrando. Mas eu falei:

- Tem gente aí, que tirou uma notinha, ó aqui quanto eu tirei.

Era 9 vírgula não sei quanto.

Ah, e quase esqueci da santinha. Pensão antigamente era difícil, levava anos, custava. Era IAPI, IAPTEC, IAPC... Meu marido era IAPC, comércio. Custava a sair, e eu trabalhava em casa de família. Um dia, lá na Serrinha, tinha um moço que tinha Nossa Senhora de Fátima, um rosário de Fátima, ele fazia a procissão... Era na Rua Operário Sadock de Sá, em Madureira, mas ele passava pelo bairro todo. Naquele dia eu tinha feito a prova, tinha passado, mas não me chamavam, tinha gente entrando com menos nota do que eu.. O pessoal com a procissão, eu com aquela fé, eu falei, eu cantava também, porque eu sei as músicas da igreja, da época do colégio. Nossa Senhora passando, ele tocando aquela música bonita, aquela banda de música, aquele pessoal, a procissão, eu falei

- Minha Nossa Senhora, eu preciso de um emprego seguro! Eu tenho minha filha, meu filho, eu preciso desse emprego!

Eu trabalhava em casa de família, depois que eu tive os dois, que o casamento acabou... Sempre eu pensei nos meus filhos. Comecei a cantar, a banda de música tocando, me deu aquela coisa, ele tocando:

Virgem mãe, Aparecida

Nossa vida e nossa luz

Dai-nos sempre nesta vida

Paz e amor

Oh, paz e amor no bom Jesus...

$\mathrm{Eu}$ ainda soltei a voz - agora estou com problema na garganta. Eu cantando com aquela fé, rezando: “Ai, minha Nossa Senhora, me ajuda, amanhã eu vou lá, para ver isso!" De manhã, quando eu acordei, que me deu aquela coisa, pensei "Vou lá!". Me arrumei e fui. Menina, tudo foi aberto para mim! Eu trabalhava em Copacabana, falei a história para a minha patroa, para sair cedo, ela:

- Vai, Balbina, vai!

Eu saí de Copacabana para ir para lá. Tudo se abriu, as portas, até o contínuo:

- Não entra aí, fica aí, faz de conta que você já estava...

O expediente já estava acabando, só quem estava dentro seria atendido. Eu entrei, falei com a chefe. Contei, conversei com ela:

- Eu quero trabalhar não é por vaidade, não, eu tenho dois filhos, meu marido morreu, tô viúva há tanto tempo com dois filhos.

Ela na mesma hora ela chamou o contínuo:

- Vem cá, Celino.

Era ele que tinha me deixado entrar.

- Vem cá, olha os documentos dela todinhos, você manda bater tudo, passa pra ela o dia para ela fazer exame. 
Botou para eu fazer exame médico, marcou tudo, aí as portas se abriram. Foi Deus. Que felicidade, menina! E entrei ganhando gratificação, nem todo mundo ganha lá. Todo mundo, o pessoal:

- Balbina, você trabalha no gabinete do Secretário de Saúde?

E eu:

- Ah, foi Deus, minha filha. Fiz concurso e não me chamavam, e os outros entrando, pedi a Deus, Nossa Senhora Aparecida, Ele me ajudou.

Fui trabalhar na maior Secretaria! Departamento financeiro da SUSEME, Superintendência de Serviços Médicos, lá na Presidente Vargas, como é aquela rua do Castelo? Sem ser a Presidente Vargas, no Castelo, aquela do Piranhão. Rua Afonso Cavalcanti... Eu inaugurei aquilo! Eu trabalhava no Andorinha, o prédio que pegou fogo, na Rua Graça Aranha com a Almirante Barroso. Ali era a zona, era baixo meretrício. Aí quando construíram o prédio da Prefeitura, nós botamos o apelido de Piranhão! Nós fomos para lá:

- Vou trabalhar no Piranhão!

E é conhecido até hoje como Piranhão. O prédio de trás, do PREVI-RIO, é Cafetão. Eu levava os processos para lá, arrumava tudo, trabalhando no Piranhão, 914.

E outra coisa que as pessoas não sabem: eu sou do tempo da Ditadura, da Revolução! Quando eu saí da fábrica, da Companhia Fiação do Rio de Janeiro, enquanto eu não arrumava emprego, fui trabalhando em Ipanema, Leblon... Eu trabalhava nos melhores lugares da Zona Sul. Em certos lugares eu não gostava de trabalhar, mas eu ia, trabalhava pela agência de emprego. Eu ia lá, eles me conheciam, tinham meus documentos todos, faziam o levantamento, para ver quem é a pessoa. Eu só trabalhava em casas assim. Trabalhei na Rua Nascimento Silva, em Ipanema, no prédio do lado do palacetezinho de Humberto Castello Branco, antes de ele ser presidente. Ele muito calmo... Eu passava, muito mocinha, bonitinha - estava viúva, mas bonitinha, que eu fiquei viúva com 25 anos - ele debruçado assim, eu descia do prédio onde eu trabalhava, no apartamento do Dr. Ivan, um grande advogado, na Nascimento Silva com a Garcia D’Ávila. Eu passava muito levada, ele brincava comigo:

- Já vai, escurinha? Vai pra onde?

E eu:

- Ah, vou lá pra a Praia do Pinto, cantar pagode!

A Praia do Pinto, na Lagoa, ali. Por isso que eles tiraram a Praia do Pinto de lá, era na Lagoa Rodrigo de Freitas. Cortava a Garcia D'Ávila e a Nascimento Silva. Eu ia pro pagode na Praia do Pinto, Cruzada São Sebastião. Dom Helder Câmara foi quem lutou para fazer e botou o nome de Cruzada São Sebastião, que as pessoas não queriam que a CEHAB (Companhia Estadual de Habitação do Rio de Janeiro) e o BNH (Banco Nacional da Habitação) fizessem os apartamentos... Eu sempre fui assim, eu fui criada em colégio de freira, eu queria aprender tudo, queria saber tudo. Aí ele lutou, porque os riquinhos não queriam a Cruzada São Sebastião, não, porque era pobre que vinha da favela, ali da CEHAB. Dom Helder Câmara era Arcebispo da Cidade do Rio de Janeiro, ele lutou muito, aquele homem, para o pessoal da Praia do Pinto. Esse pessoal que depois veio aqui para a Avenida Brasil, cidade alta, era tudo 
da Zona Sul. Aí o homem fez os apartamentos e disseram que tinham que vir pra cá, para cima. Era ali.

Dia 31 de março foi a Revolução de 1964, não esqueço nunca. Ficou a Ditadura, o povo saía para a rua, aquele caminhão do Exército, no Castelo, eles vinham assim, o povo pelas galerias, por baixo dos prédios, o povo vinha gritando, eles jogavam o povo para correr, o povo jogava troço no caminhão do Exército, era lá, a gente lá de cima olhando isso. Assistia tudo. Daqui a pouco o Exército está pela outra galeria, na Cinelândia. E o pessoal gritando para acabar a Ditadura. O Exército tomava tudo. Aí a gente ficava lá de cima olhando:

- Ih, o caminhão do Exército!

A gente vendo, daqui a pouco vinham os estudantes da faculdade, tudo. Eu ficava lá de cima vendo, e quando a gente descia:

- O trem parou!

O trem parava:

- Ai meu Deus, como é que a gente vai para casa?

Era! O trem parava, a Central do Brasil, o povo quebrava, o Exército na rua. E estava a polícia do Exército, que vinha nas casas para apanhar as pessoas... Para ser preso. E o pessoal brigando, saindo na rua, no Castelo, Cinelândia... Lá, porque tinha muita faculdade... Ih, fábrica parava! Eu acompanhei tudo isso, que eu trabalhava no meio... A Ditadura terminou... Não podia falar nada não. Governo militar, Castello Branco foi levado para assumir Brasília.

Naquele dia eu não dormi, que a gente morava do lado, a gente no quarto dos empregados, a gente via na calçada dele a polícia do Exército, ninguém passava na calçada dele, tinha que ir por baixo. Eu:

- Ih, o cabeção tá todo policiado!

A minha colega, Romana, que era empregada do Castello Branco, ela foi lá me abraçar, falar com a minha patroa, Dona Maria José, que ela foi junto para Brasília... Ela era do Norte, uma escura, não tinha família aqui, não. Veio e...

- Balbina, o vôo da gente já está marcado para ir para Brasília.

Daqui a pouquinho vinha o pessoal da Cruzada São Sebastião, fazendo festa. Eu vi tudo! Aquela que hoje é igreja era o cinema na Praça Nossa Senhora da Paz. Quando ele foi embora, no carro, acenou para a gente. Aí eu digo:

- Romana agora está bem...

Mas morreu, não é? Como é que ele morreu, foi no avião? Na Serra das Araras, não foi? Todo mundo morre ali. Roberto da Silveira, Governador, não sei se o avião caiu ou se foi o carro. E o Castello Branco também foi avião. Eu fico: Hmm, Getúlio Vargas deu tiro - mentira! Deram tiro nele. O que é que há? O Repórter Esso, a gente escutando, aquele debate no rádio, não tinha televisão, não. Aquele rádio lá em casa de tio João, que foi o primeiro presidente do Império Serrano, João Gradim, estivador do Sindicato, genro de Seu Elói. A gente escutando, Carlos Lacerda atacando muito, atacou muito! Ele era muito guerreiro, mas a gente não esquece. A gente escutando, naquela noite, ele:

- Quando Getúlio sair, tem que lavar o Palácio com aguarrás!

Foi por isso que ele nunca ganhou eleição. Eu era novinha, mas eu era envolvida, porque eu fui do colégio interno, tinha que ver tudo. O Cais do Porto inteiro era Getúlio Vargas, foi ele que resolveu tudo do Cais, para melhorar a 
situação... Todo mundo escutou. Outro também, que brigava com Getúlio, era Brigadeiro Eduardo Gomes. Quando era eleição a gente saía pro Getúlio, Eduardo Gomes nunca foi eleito. Ele era racista, de pobre e de negro. Negro não votava nele, o pessoal:

- Vota no Brigadeiro!

Mas Getúlio ganhava de lavada, de montão. O Brigadeiro também massacrava o Getúlio, que era um homem humilde. Mas aquele suicídio do Getúlio eu não engoli nunca!

A gente estava trabalhando, na fábrica, na Borborema... Ele foi o homem que nos deu maior direito, ao trabalhador. A fábrica de tecidos é barulhenta, ela tem várias máquinas, com vários movimentos. E os barulhos são diferentes. Eu trabalhei na fiação, dobração e maçaroca. No SENAI, eu aprendia todas as máquinas, qualquer máquina que faltava alguém eu cobria, porque eu sabia trabalhar em tudo, eu era profissional. Eu me lembro, eu novinha, a gente trabalhando, escutando aqueles negócios de política, aquele Gregório, segurança do Getúlio, e a gente trabalhando triste por causa dessa coisa... Daqui a pouco o rádio tocando:

Tararará-tará

Tarárarará-tarárarará-tarárarará-rará

Tá-tá-tá-tá-tááá

- É com tristeza que nós levamos ao Brasil a triste notícia: acaba de suicidar-se, no Palácio do Catete, o Presidente Getúlio Dornelles Vargas.

Ahh! A fabrica parou. O barulho foi assim, estalou. O pessoal chorava, a gente desesperada na fábrica. Getúlio foi o pai dos pobres, o resto foi conversa fiada! Passei por eles todos, Getúlio, Dutra, Café Filho, quem mais? Passei por mais. Eu digo de votação, depois vieram esses homens que os militares botaram, mas que nós botamos foram esses. Juscelino Kubitschek, também morreu de desastre. Não é estranho? Eles morreram de desastre, de tiro, se matou, matou nada! E ninguém investigou...

Agora uma coisa, que eu estou me lamentando, é que o povo brasileiro está muito, como é que a gente fala? Aceitando tudo, agora. Não pode ser assim, não, tem coisa que a gente tem que botar o dedinho da gente, porque depois que a gente quiser botar o negócio está formado e firme. Você vê aí, Cuba! Que país horrível! A gente vê um programa aqui, no canal 13, que programa bom. Eu não fico só vendo besteira não, passa coisas do mundo inteiro. Gente que coisa horrível, isso é bom para o pessoal não ficar falando que comunismo... Que tristeza, meu Deus, para comer tem fila. E outras coisas piores! Eu digo para as pessoas verem canal de instrução, não ficar vendo só bunda. Gente, mas Cuba dá pavor, e eles ficam com Fidel Castro, adorando... Como é que é, Jussara? Com caderninho para comer! Menina, eu fiquei assim! Agora ficar vendo dança da bundinha... A Ditadura não foi tanto, Ditadura é aquilo lá! Tudo racionado. Nem água quente, luz, um frio... Meu Cristo Redentor, e depois ficam dizendo que é bom. Tem que ver esse canal, canal 13, mostra África... Eu trabalhei bem durante a Ditadura, entrei em 1967, minha filha está bem, minha neta... Ela também te ensina. Viver, você tem que ser assim, você tem que dar o teu exemplo, se eles não quiserem, aí o problema é deles.

Ah, mas a vida é assim, minha filha, o Império foi isso. O Império Serrano era muito bonito, e a gente cantava muito. Tinha harmonia! $\mathrm{O}$ diretor de harmonia exigia e a gente cantava onde a gente chegava, e o Império foi crescendo mais ainda, vindo gente de fora pra sair no Império por causa do capricho e da moral. Antigamente era 
a Tia Eulália que botava ordem... Ih, mas por causa de namorado tem sempre briga de mocinha, não é? Uma quer bater na outra, quando a gente é mocinha... Ela botava a gente de castigo, a gente era suspensa. Teve um ano que eu briguei lá dentro, briguei assim. Ela disse que eu não ia poder ir, que àquele ensaio eu não ia... Eu digo:

- Não vou não, é? Não vou não?

Saí um ano na Portela! Fui para a Portela, que era inimiga. Que eu tenho meus amigos, lá, também. A Portelinha era umas duas ruas depois da fábrica de tecido, Borborema, ali. Minhas amigas, que trabalhavam comigo, umas eram Portela, e a gente ia aos pagodes na Portelinha. O Portelão, que veio depois, era a garagem do ônibus Madureira - Tiradentes, linha 355. Ih, eu não saía lá da Portela. Eu estava sozinha, namorava o Dinho, da bateria da Portela. Mas foi isso, e o Império foi isso, era moral. Tia Eulália não gostava. Mulher que ficava xingando palavrão, bebendo demais, Fuleiro chamava atenção:

- Menina, Dona Moça!

Dona Moça, ele chamava.

- Dona Moça!

Quando a gente estava fazendo qualquer coisa errada. Foi isso, o Império. Seu Elói Antero Dias era genro do tio João, pai da minha tia, que casou com tio João, ele foi um dos fundadores do Sindicato do Cais do Porto, dos estivadores, presidente do Sindicato, ele também era Império. Morava perto da Portela, criando os filhos, mas ele era Império. Ele foi um, também, que ajudou muito a fundar o Império Serrano, ele adorava meu tio, genro dele. Foi Seu Elói Antero Dias, João de Oliveira, Mestre Fuleiro, Molequinho, Seu Zacarias... Seu Zacarias morava aqui, nesta rua. Lembro bem. Manolo, era avô daquele menino que era diretor de bateria do Império que este ano não saiu. O Átila! Todo mundo, eu conheci tudo através do Império, porque a minha família fundou, onde eu nasci, saiu lá de cima, porque vai melhorando e a quadra caiu, nesses temporais que vai dando nos barrancos do morro, caiu a quadra.

Aí o Império ficou ensaiando no Madureira Tênis Clube, ali ao lado do Distrito de Madureira, antigamente tinha, agora não tem mais. Depois foi que fizeram o Mercado de Madureira. Só o Império ensaiava nesse lugar, porque o Tênis Clube era metido, não entrava preto, nem gente pobre, a maioria de brancos, e brancos de situação. Só o Império Serrano ensaiava lá, a gente bem arrumado, aquilo bonito, sabe? Só o Império Serrano. Moacir Cabeça Branca, que morreu do coração, foi quem botou o Império dentro do Tênis Clube, para ensaiar, ele foi também presidente... Eu digo: lembraram do Império e esqueceram o Moacir, que também lutou muito para o Império ficar lá naquela quadra, era o Mercadão de Madureira, aquilo sujo. O Império conseguiu, estava sem quadra, o administrador de Madureira, não lembro o nome dele - antigamente tinha prefeitinho, administrador. Moacir, como a família dele foi uma das primeiras do Mercadão de Madureira, também ajudou, senão o Império não teria lugar para ficar. Na Ministro Edgard Romero, no Hotel Omaha, ali era uma casa velha, o Império ensaiou naquele quintal, ficou sem quadra, aí depois que fez o Mercadão.

E outra coisa, aquele viaduto ali, Negrão de Lima, não ia ser Negrão de Lima, quando começou a fazer. Ia ser Salomão Filho. Diz que Madureira era aquela Madureira ruinzinha, ainda é, mas não era como agora. Antigamente tinha muito 
gringo, o nome desse era Salomão. Vendia ouro, naqueles tempos que vendiam ouro na porta, batendo a palma assim, e com aquele sotaque:

- Madame! Quer comprrare?

E o pessoal em Madureira com aquele ouro, aqueles cordãozão, eram os gringos, Abdala, o pessoal botava apelido naqueles gringos, e eles vendiam fazenda:

- Vai comprare? Pagare quatro vezes...

Em algumas famílias as mulheres não pagavam, coitados. Vendia aquele ouro, e elas não pagavam: quando ele chegava na porta para cobrar, mandavam as crianças dizerem que não estavam, que estavam doentes, que estavam no hospital, no hospício, se fantasiavam de malucas, eles corriam! Era, Madureira tinha isso, elas com o cabelo em pé e eles corriam, coitados. Olha, os gringos sofreram muito, hein? Sofreram muito naquela fase em Madureira, elas diziam que estavam malucas e botavam os gringos para correr. Compravam ouro, roupa de cama, não tinha cartão, não tinha prestação, aí as mulheres compravam dos homens até ouro, aquele ouro bonito... Coitados dos gringos.

Aquelas lojinhas todas, ali, eram de gringo, depois do Mercado. Ali na Rua Conselheiro Galvão, ali na esquina, eu me lembro bem, a família Duba era dona de quase todos aqueles armarinhos de Madureira. José Duba. Eu digo, eh, Madureira? Ninguém me engana não, José Duba foi presidente do Madureira Atlético Clube... Aquilo tudo é da família Duba, até lá embaixo, passando o Mercado na Rua Conselheiro Galvão, onde é o Madureira Atlético. José Duba era dono de fazenda, tudo de gringalhada. O pessoal chamava o viaduto de Salomão Filho. Eles que lutaram, essa gente, para Madureira melhorar, não tinha viaduto! Os ônibus iam lá pela Rua Oliva Maia, lá por dentro. Para ir para Jacarepaguá e Cascadura, tinha que ir pra lá para poder pegar do outro lado de Madureira, ou então lá para Bento Ribeiro, onde tinha cancela.

Carnaval não era esse luxo, era aquela vontade, gosto. Agora é para aparecer na televisão, é mulher botar a bunda com fio dental, rebola, aquela mulher que está rebolando é que eles pegam bem, não é como antigamente. Parece até que a gente está indo para o matadouro dos bois. Não vejo nada naquilo, um lugar horroroso, tudo bem que eles fizeram para ganhar dinheiro, né? Eu não acho graça naquilo. Eu vou porque eu sou Império e a minha voz faz falta. A escola de samba, não pensa que é só roupa bonita e bunda, não. É harmonia, a pessoa cantar. Porque se você passar e não cantar, de quê que adianta? Então eu vou, eu digo, eu vou, mas esse ano eu também já não estou muito, por causa da artrose, eu tenho que operar e está doendo muito. Eu já estou cansada, também. Depois de 73 anos, eu já fiz tudo. Tudo que Ele me deu foi muito bom para mim. Mas a minha força de vontade, Ele me deu força! Fiquei viúva com 25 anos, tive dois filhos...

Ah, a mulher que tem muito filho, eu não sei por que, que essas mulheres são malucas! Já tinha isso tudo, tratamento, tinha remédio para você não ter mais, não sei por que encher a casa. Minha mãe teve 11! Eu fiquei traumatizada. E morreu novinha. Mas a pobreza, de antigamente... Eu digo pro pessoal que nós agora não somos pobres! O pobre agora tem tudo, aquela época não tinha nada, gente! A minha mãe com 11 filhos e não tinha tratamento para não ter mais! Eu jurei que eu não ia ter, eu não ia ser igual à minha mãe. Eu tenho revolta até hoje, não gosto quando eu 
vejo mulher cheia de filho. Cruz-credo... Gente, agora tem coisa para você não encher a casa.

Agora o pobre tem mais posse. Tem escola pública, tem médico, antigamente não tinha! Pobre era pobre de marré deci, com diz aquela música. Tinha casa que não tinha rádio na minha época. Casa, agora, é telha de alumínio; antigamente era telha de zinco. O pobre, se ele souber levar a vida, nós que trabalhamos, nós que temos emprego, direitinho, se você souber levar a sua vida, prestar atenção na hora de trabalhar com o dinheiro, você não fica mal, não. Eu nunca ganhei rios de dinheiro, não. Eu sempre procurei trabalhar bem com meu dinheiro, não gastar meu dinheiro em besteira, eu sempre falei isso, ainda digo um palavrão: eu não vou trabalhar para comer e cagar, não. É assim que eu digo. Aí trabalha, compra comida... E na minha casa não faltou comida, mas você tem que saber tudo direitinho, como fazer.

Eu fui para o conjunto Votorantim, ali perto da Serra do Mendanha, subindo depois da Vila Kennedy, na Avenida Brasil, na CEHAB. No meu conjunto só tinha polícia, funcionário público, dos Correios, não tinha bagunça, não. Eu vendi por causa do meu filho, ele dá muito trabalho, eu não podia ficar lá sozinha, e tudo da gente é no Irajá, os dois nasceram aqui... Eu fui para a CEHAB. Aí quando aconteceu o acidente com ele, ainda fiquei uns tempos lá. Ele tinha 25 anos, agora está com 51. Eu, aí, vim-me embora. Mas nunca deixei de pagar a CEHAB. Para você ver aí, como o dinheiro, para quem tem juízo, cresce. Depois que aconteceu isso aí com ele, foi que eles me transferiram para eu ficar mais perto de casa. Fui trabalhar no posto de saúde lá do Mendanha. Perto da minha casa, e tinha redução de carga horária.

Eu trabalhava dia sim, dia não. E eu nunca ganhei muito, mas sempre tive. Meu apelido era arquiteta na CEHAB.

- Chegou a arquiteta!

E eu:

- Não, não quero assim, não! Minha casa eu quero assim.

Eu gosto de casa modelada, tudo sou eu. Agora, tem gente que já não gosta de pagar, é por isso que vive sempre enrolado. É o que eu digo: gente, o banco manda até coisa aí, para a gente apanhar empréstimo, se quiser... Mas é isso, a gente tem que ter aquela moral; mas não, quer ficar na bagunça bebendo, eu digo, eu posso beber, eu bebo minha cerveja, eu não gosto de dever a ninguém. Tudo direitinho, minha casa. Fui passear, passeei, minhas tias têm casa em Sepetiba, eu ia para lá... Sabe o que é que eu fiz? Fui passear, aí estou vendo o pessoal loteando um terreno, levando o povo para ver. Eu lá, vou ver um terreno aí. He-he. Fui lá na casa da minha prima, do meu colega, que morava lá e faleceu também, um grande amigo meu. Falei assim para o vendedor:

- Gostei desse terreno, vou comprar esse terreno.

E ele:

- A senhora vai comprar?

- Eu vou vir aqui amanhã, comprar esse terreno.

Comprei, em Sepetiba. E fiz minha casinha, também em Sepetiba. E a de Campo Grande eu vendi. Gente, é bom andar limpo, andar direita. Se você for mau pagador numa coisa, você vai ser sempre, você não vai ter responsabilidade com nada. Eu pagava colégio dos meus filhos, ganhando pouco, meu marido deixou um salário mínimo. Nunca fiquei devendo a ninguém, é a primeira coisa que a gente fala 
aqui em casa: pagar as dívidas, primeiro. Essa casa quando eu quiser eu vou, digo que é a minha lama, porque em Sepetiba está tudo poluído, a praia, mas eles estão botando os esgotos, trabalhando, sabe? Mas eu sento, que tem seresta lá, os vizinhos são amigos, é bom... Aí, depois que eu vim para cá, tornei a vir, fiz o espaço do meu filho ali, e minha filha aqui. Eu?! Por isso que a minha pressão é 12 por 8 . Ah, vou sim, vou para Sepetiba. Fiz meu barraquinho lá, mas aqui vendi o de Campo Grande, porque são dois andares e terraço. Ih! Que eu digo: gente, presta atenção, hein? Pouco dinheiro, se você souber, você segura. E nunca andei molambenta. Tenho tudo que eu quero. Eu sou Balbina, eu digo: não, eu hein?

Quando eu era criança, minha filha... Os médicos, psicólogos, com quem eu trabalhava na administração, eles falam que a gente em criança, quando escuta coisas, sente, traumatiza. Uns não, uns pegam aquela ofensa pro bem, não é? Você aí aprende: "eu vou mostrar que eu não sou aquilo". Eu sou assim, bato meu pé, assim. Eu quando era criancinha, minha mãe me deixou com 12 anos, meu pai com 5 . Depois a gente vai para ficar com tios, ou alguém... Eu escutei muita coisa, eu tive humilhação represada. Tio não é mãe, nem pai. São poucos tios que amam aquele sobrinho que é órfão de pai e mãe, que se faz pai, que se faz mãe pra eles. Sempre tem uma coisa que eles soltam.

As crianças todas gostam de mim. Eu digo, deixa meus melequinhos! Ah, mas eu gosto deles. Nunca se diz uma coisa que vai machucar uma criança, pelo amor de Deus, mas eu tive isso. Aí eu jurei, meus filhos não vão ouvir isso! Deus vai me ajudar. Quando eu fazia, assim alguma coisa errada, ouvia... Minha tia Neném, madrinha da minha filha, me ensinou muita coisa boa, quando me chamava a atenção, que eu fazia alguma coisa errada que eu não sabia, eu era inocente. No colégio você é inocente, no meio de meninas, de freiras, a gente não sabe nada daqui de fora... Mas a outra, não sei se por ignorância, casada com meu tio, morava na frente, e vinha, que elas se davam. Quando minha tia estava brigando comigo, meu Deus, Jesus - eu converso com Deus -, o Senhor sabe a dor que a pessoa sente. Eu com 14, 15 anos, trabalhando. Cheguei, o emprego estava me esperando na Rua Borborema, Companhia Fiação do Rio de Janeiro. Eu trabalhando, eu não ganhava mal, não, que eu estudava no SENAI, estava como profissional, tinha as que não eram, que iam limpar chão.

- Ah, isso é gente que não tem onde cair morta.

Que a gente não tinha pai, não tinha mãe. Minha mãe não deixou, tinha a casa lá em cima, que era do meu pai, mas ninguém queria ficar lá em cima, que era alto do morro. Só as mais, que precisavam mesmo, ficavam lá em cima. Eu ouvi muito isso:

- Vocês não têm aonde cair morta.

Eu jurei que ia me casar, mas se eu tivesse filhos, eles não iam ouvir isso! Eu tinha um ódio, fiquei traumatizada. Eu recebia por quinzena: uma quinzena era minha, uma quinzena era da casa. Lógico que eu estava comendo, vivendo, e a tia Neném me ensinou logo no primeiro pagamento. Eu nem sabia o que é que era Caixa Econômica Federal, não conhecia, e na Caixa Econômica de Madureira ela me ensinou a abrir caderneta:

- Quando você tiver o seu dinheirinho, o que sobrar, você bota aqui. Aqui teu dinheiro vai ter juros... 
E eu andava com paletó de visom. Paletó de visom é aquele de pele, francês, só gente que tinha dinheiro, madame, é que usava. Eu andava bem vestida, eu era uma das mocinhas mais bem vestidas do Império e lá de Madureira, Serrinha. Eu via modelo, aquela loura, Marilyn Monroe, sei lá. Aquele paletó de pele... O pessoal do Sindicato do Cais do Porto, os estivadores, ganhavam bem. Naquela época, todo mundo queria namorar os homens do Cais do Porto, em Madureira. A minha tia tinha, o marido dela, elas iam para a festa, na estiva, no Sindicato, elas botavam aquele paletózão de francesa, e eu botava meu bolerinho. Ha-ha, bonitinha! Aprendi a poupar. Foi minha tia, Neném, mulher do Tio Molequinho, que me ensinou a poupar. Nunca mais eu deixei de ter uma cadernetinha, tive todas. Ha-ha! Já saí da Caixa Econômica Federal, já tive BANERJ, Unibanco, aquele Banco Nacional, tudo!

Quando eu trabalhava na Graça Aranha, no $10^{\circ}$ andar, no financeiro da SUSEME, eu dizia:

- Olha, meu serviço tá todo prontinho, eu vou lá em baixo, vou resolver um problema lá embaixo.

Aí eles ficavam todos lá, na janela, quando eu descia do prédio:

- A portuguesa preta já vai!

Eu caía de rir. Meu chefe me chamava de Bibi, falava assim:

- Onde cê vai, hein? Eu acho que você não é Bibi, você tá com a portuguesa preta!

Sabe o que é que eu fazia? Eu ia lá no BANERJ aquele central, eu conhecia gerente, todo mundo, que eu trabalhava há muito tempo, recebia lá também. Eu chamava o gerente, naquela inflação que engolia o nosso dinheiro.

- Vem cá!

- Senta aqui, Bibi!

- Vem cá, se eu botar tanto na caderneta, este mês, vai dar no mês que vem quanto, hein?

Aí eles calculavam lá, na máquina, que não tinha computador, e eu lá, aí eles diziam... Eles me conheciam porque eu era da saúde, era Estado naquela época, a Prefeitura veio depois da fusão do Estado do Rio de Janeiro, que passou a ser Estado e Prefeitura, antigamente era só Estado. Eu trabalhava no departamento financeiro e depois fui para licitação, que é onde se compravam as coisas para hospitais, tudo. Ele vinha, eu ganhava gratificação:

- Minha gratificação eu vou aplicar.

E ele:

- Aplica, Bibi, que vai dar tanto em cima dela!

Ah, eu botava meu dinheiro lá, o dinheiro que sobrava... E eu dizia para eles, eu tenho sangue de português mesmo, eu tenho, da África portuguesa, meu avô era filho de angolano! Angolano gosta de dinheiro. Olha, o pessoal ria.

- Bibi, quanto foi a inflação?

- Ele disse que a inflação desse mês subiu não sei quanto, meu dinheiro rendeu não sei quanto!

Fazia, ainda faço, ainda fico assim com a Jussara. Décimo terceiro agora, a gente vai receber em agosto, metade. Eu já estou assim para ela: bota lá, a metade. Foi assim que eu nunca mais pedi dinheiro emprestado a ninguém. Hmm, aprende a 
viver com pouco dinheiro, gente! Eu aprendi. Ainda comprei meu terreno em Mauá, Magé. Comprei outro terreno lá. O pessoal:

- Olha lá, a portuguesa preta!

Eu ria muito com eles. Agora todo mundo se aposentou, até o meu chefe. Nem Oswaldina, que era da $\mathrm{OAB}$, eram as secretárias da $\mathrm{OAB}$. A gente tem que fazer isso, minha filha, aprender a lidar com pouco dinheiro. Eu vejo gente aí, que recebe um dinheirinho, troca o móvel! Eu não vou trocar móvel nenhum, eu compro móvel bom... A minha estante ali, a minha neta Ana Paula não tinha nem nascido. Eu morava na Vila da Penha. Está aí, bonita, aquela estante.

Eu sou espírita e sou católica. Sou católica por causa do colégio interno. E ajudo as minhas criancinhas, ajudo no que eu posso, na Rua César Zama, no asilo das velhinhas, lá no Lins, a gente levava tudo... Eu dôo pro Instituto Nacional do Câncer, para os cegos, aqueles meninos de Olaria, os meninos vêm aqui buscar todo mês, por quê? Porque Deus me ajudou, me deu força. E Deus me deu força, quando aconteceu isso com meu filho, foi uma coisa terrível... Foi acidente de carro. Uma coisa terrível. Eu não desmaiei, não gritei, eu fiquei assim, mas Deus me dando aquela força:

- Vai, Balbina, vai!

Porque tem mulher que desmaia, não vai nem ver, né, coitadas. Deus me deu. Isso que agradeço muito a Ele, eu não vou a igreja nenhuma não. Eu digo: Deus está no coração da gente, não é em igreja. Muita gente está lá dentro, não dá uma coisinha para um pobre caído, e ainda debocha. Eu não. Eu aprendi, eu acredito em Deus, Ele sabe, Ele me deu muita força para tudo. Às vezes eu xingo, não sei quê, e eu digo:

- Ai, o Senhor me desculpa, eu estava nervosa, sabe?

A gente cantava com as freiras. Cantávamos os hinos da igreja. Minha família, principalmente minha mãe, minhas irmãs, nós temos esse tipo de voz. A gente sempre gostava de cantar, assim, eu Marina e Gina, as outras irmãs eu não sei, do segundo casamento, que minha mãe teve 11 filhos. Mas a gente, do primeiro, a gente gosta de cantar. Foi isso, mas sempre cantei no Império, no Asilo, aí estou na Velha Guarda, me convidaram, eu acho que foi Neide que mandou me chamar. Porque eu sou fundadora do Império, tinha gente na Velha Guarda que não tinha nada a ver com o Império e botaram na Velha Guarda, e as pessoas que são Império mesmo, desde pequenas, não estão. A falecida Neide, ela sempre gostou da gente. Um dia ela chegou perto da minha prima:

- Eliana, diz à Balbina para vir aqui, que eu quero falar com ela.

Ela gostava também muito da minha filha, que costurava muito com ela. Minha filha ficava lá no ateliê e eu gostava muito dela, era uma mulher de fibra igual a mim, eu gosto de gente assim. Ela mandou chamar minha prima Eliana, neta da Tia Eulália, que queria falar comigo. Aí eu fui, quando eu cheguei lá, ela falou:

- Balbina, você agora vai para a Velha Guarda show.

E, antes disso, o samba do Silas eu que jogava na quadra... Eu fui sair com 14 anos, já tive ala no Império, minha ala era o nome mais bonito, mais certo que eu achei, e a gente saía bem vestido: Mistura de Raças, cada um comprava sua roupa, não tinha nada de levar vantagem, de comprar, dizer que foi um preço... A maioria eram todas amigas. A Leila Diniz saiu na frente da minha ala em 1972, no Alô Alô, 
Taí, Carmem Miranda, saiu na capa da revista. O pessoal foi para a França e eu não quis ir...

\section{Uma pequena notável}

Cantou muito samba

É motivo de carnaval

O Império ganhou primeiro lugar

Pandeiro, camisa listrada tornou a baiana....

Meu marido participou de uma das primeiras alas fundadas do Império, Milionário. Ele saía muito bem vestido, meu marido. Outra que aparece nas fotos antigas, Simplícia, essa foi com 96 anos que ela faleceu. O nome dela, a minha avó parece que adivinhou, ela era uma simplicidade. Naquela época, o negro, que morava na Serrinha, a maioria era no morro. Essa minha tia, ela já tinha a casinha dela na Rua Itaúba, agora Mano Décio. Ela já tinha a casinha dela, porque o marido dela já era da Light, mas ela era uma simplicidade, não era como pessoas que têm as coisas e querem se exibir. Ela não. E eu pensava: "Vovó botou o nome certo". Ela tinha a roupa comum, a casa dela limpinha, ela não diminuía ninguém... A única que já tinha casa ali - quem tinha casa ali embaixo, já diziam que era rico - era igual carro. Antigamente pobre não tinha carro, hoje em dia pobre compra carro, troca carro. Lá em Madureira aquele que tinha carro as pessoas já sentiam que era rico. Era! Eu sabia o nome de todo mundo que tinha carro. Seu Adamastor, não esqueço nunca, ele que fazia a passeata para o Império, porque antigamente o grito da escola era passeata de carro, com todo mundo vestido, as alas iguais para ver qual era a ala que estava mais bonita, vestidinho, e o carro, cantando as músicas pelo bairro... Era, no bairro, era o grito de carnaval da escola. Agora...

Isso já vinha mudando. Ali foi tudo junto, já vinha mudando. Mudou mais quando veio o negócio de escola de samba de bicheiro. Bicheiro não, bicheiro é quem trabalha para eles. Banqueiros. Foram eles, eles tiraram todo o brilho das escolas de samba. Eu digo, foram eles! E foi na Ditadura, ainda digo isso.

Eu acho que a velha guarda é uma coisa boa para as pessoas relembrarem, as pessoas de idade, mas as velhas guardas agora não têm quase nada que relembra coisas antigas das escolas de samba... Tem a Velha Guarda show, não é? Mas para mim é uma coisa comum. Não estou vendo nada, é uma coisa comum. É um grupinho que canta, que leva o nome da escola, mas não vejo muito não. Na Velha Guarda show, uma faleceu até agora, a irmã da Nina, que estava doente há um tempão, e eu não escuto falar em botar ninguém. Se uma fica doente, partir, como a outra, tem que colocar outra pessoa, não é isso? Mas pessoas da velha guarda da escola, não pessoas de outra escola, por questão de coleguismo! Isso é que foi o errado, em certas Velhas Guardas. Tinha que entrar pessoas que eram antigas da escola; por questão de amizade, de sei lá eu de quê, eles pegam e botam pessoas que não tinham nada a ver com a velha guarda da escola. Tinha muita gente na escola, que podia estar na Velha Guarda show, e canta! Porque é uma Velha Guarda show, para fazer show. Se as pessoas não dançam e não cantam, por que estão lá? Vai para a velha guarda comum. Tem a velha guarda, que são as senhoras que saem no carnaval, não é isso? Eu não, que eu sempre fui assim, não ia para a velha guarda comum, que eu gosto de cantar, sambar, pinto, bordo.

Mas aqui a gente tem que gravar, você tem que ter boa voz, você tem que ter uma voz que agüenta um agudo, tem que ver isso também! E estava na escola há 
muitos anos. Não vi isso na Velha Guarda show do Império, houve esse erro! Eles não botaram pessoas antigas que cantam, que dançam, que têm história na escola desde criança. Velha guarda é aquele que tem história, tem um histórico no meio, porque se não você não pode estar numa Velha Guarda show da escola. Que história você vai contar? Você quando nasce não tem um histórico? Não tem que ter? Para conhecer, de onde você veio, como é que foi criado, no quê que tu era danado, ali, saiu, foi estudar, não tem que ter?

Então, uma velha guarda, até a comum, tem que saber se aquela pessoa desde moça estava na escola, é uma história. Vem gente estranha, que não tem nada a ver com a escola, nunca foi da escola e entra para a Velha Guarda. Isso não está certo! Quantas que são criadas ali, que cantam... Política, polêmica. Isso não pode acontecer. Tem muita que eu digo: ué! Essa daqui nunca foi da escola, vem aqui com pose, não pode! O Império tem tantas... Quando foi para o Mercado de Madureira, não tinha telhado, o Império estava sem quadra, depois o trem entrou... Mocinhas, mulheres, na hora do ensaio, quando chovia, para poder ensaiar, ficavam com vassoura tirando água, para a gente poder ensaiar. São essas que lutam pela escola! Pessoas que chegam, sem mais nem menos, ainda querem chutar a pessoa antiga! Quer ser mais na escola que a pessoa antiga, não pode.

Todas as escolas têm isso. Quando vê, elas entraram ontem, querem mandar mais que aquela que sofreu com a escola. Não pode! Eu não aceito. Eu sou ariana. Já digo mesmo, ariana é danada. Eu não aceito nem no quintal da minha casa, ninguém fala mais alto de que o tom primeiro, que é meu. Tem que ir a pessoa mais velha, ela conta a história, ela sabe. Outra vez que foi um sofrimento, que o trem saiu do trilho e entrou na quadra, as meninas, aquelas senhoras trabalhando com o bombeiro, $\mathrm{o}$ trem dentro do Império, aquela tristeza... O Império sempre passou essas coisas. E pessoas que chegam aqui, no bem bom, querendo ter mais posição... Eu digo, eu não aceito. Eu, negativo! Agora, nas escolas de samba existe isso. $\mathrm{O}$ mal é esse. E você que é antiga na escola, que sabe, lutou pela escola, nós que sofremos com os deboches da Portela... A Portela debochava do Império à beça, a gente menina! Não podia brigar, não é? Que a família do Império nunca gostou da briga de rua, não. As mães, os pais, apanhavam as mocinhas:

- Vamos embora!

A gente sofreu feito não sei o quê.

Ah, eu já falei para eles: eu não vou vir mais não! Eu não vou dançar na avenida para maluco bater palma!

Para mim, o melhor são as lembranças. A escola de samba não está com mais nada, gente. Antigamente tinha o Teatro Municipal, não tinha? Tinha aquele show, no Teatro Municipal, desfile de Miss, enchia, para entrar era ruim! Agora, está tudo jogado. Nem Miss mais, desfila no Municipal. Tudo vai se acabando, não é? E escola de samba também vai se acabando. Aquela história boa, não tem mais não.

Hoje em dia as pessoas são muito ambiciosas por dinheiro, né? O povo mata, arruma confusão, fofoca, por dinheiro. Não está valendo mais não! A escola de samba, agora, é o dinheiro, é isso. Dinheiro e a posição, de aparecer. A pessoa não está na escola porque gosta da escola, não, quer aparecer! Eu não, gosto da minha escola, foi lá na minha casa que eles fundaram, eu não quero aparecer! Se vem uma câmera de televisão, eu saio correndo! E eu digo, meu Deus, o que é isso? Nada, 
agora... É tudo vaidade. Não é mais aquilo de dentro da gente. Não, um empurra o outro, e eu: cruz-credo! Escola de samba, minha filha, não tem mais aquilo que tinha.

É igual ao Teatro Municipal, não tem mais nada! E todo mundo botava aqueles vestidos, n'era? Quem não podia entrar ficava lá fora, esperando chegar, as Miss saltarem, para ver, que gente pobre, que não tinha dinheiro, não podia entrar. $\mathrm{Hmm}$, agora as baratas voam lá! Vai acontecer com escola de samba. Escuta o que eu estou te dizendo. Aquela passarela lá, aquele Sambódromo, vai chegar um tempo - já não está muito cheio, como era, naquele tempo era cheio - Hm! Você vai ver, aqueles gatos pingados, o pessoal pedindo pelo amor de Deus para eles entrarem. O povo está enjoado também, e essa chatice, é um disse-me-disse... Escola de samba é lucro. Que se danem os outros! Eu não, que o meu dinheiro eu não dou.

Agora, com esse negócio de internet, como é que é? Que eu estou velha, não quero nem saber. Vende a fantasia pela internet, não é? Depois as pessoas pagaram, chegam e não encontram! Já teve. Escola de samba não está com nada não, enganando os outros, quando a pessoa chega na avenida, cadê? Cai fora! Eu digo, ah, antigamente não era isso, era uma beleza, era a beleza, mesmo.

$O$ pessoal não ensaia, estraga a harmonia, bota ala que não tem nada a ver com a escola. Vende, para a Zona Sul, como é? Comunidade Zona Sul. O que é que escola de samba daqui vai ter comunidade Zona Sul? Ah, eu num agüento isso, é dinheiro... Eu? Digo, ih... Estou porque é o meu Império e eu gosto de cantar, e para sair de casa um bocadinho, mas não está com nada. É uma vaidade terrível. Que você está vendo que aquilo não vai dar certo, mas a vaidade... He-he! Digo, eu não, quando estou na Velha Guarda eu canto, jogo a minha voz. Que eu gosto de cantar. Eu gosto é disso, nunca quis ser profissional mesmo, nunca quis. Mas canto, comum.

Ó, comprei um cavaquinho! Vou aprender. Minha neta, falei para ela: vamos arrumar um conjunto. Eu toco, ela aprende cavaquinho, eu toco teclado, que eu gosto de piano também, que é da época do colégio interno. Eu ia entrar para a aula, quando eu vim-me embora, que me tiraram de lá. Eu sei as primeiras notas: dó-ré-mi-fá-sollá-si-dó. Volta: dó-si-lá-sol-fá-mi-ré-dó. Eu digo: vamos fazer aqui uma... Tá aí o cavaquinho, agora vou comprar o teclado, o teclado é meu.

O enredo da Portela quando eu desfilei foi aquele, quer ver? Foi.. Ai, peraí.

Dom João VI magistral

Ao passar pela estrada da Bahia...

Não. Tenho que lembrar!

Com destino ao Rio de Janeiro

Quando aqui desembarcou

Com toda a família real...

Não foi esse não, foi... Foi de dança, que eu saí na Portela.

No dia do seu casamento

A Ordem da Rosa ele criou

A Corte estava engalanada

Era um lindo cenário

De raro esplendor...

Eu cantava e o pessoal gritava, assim, no Império:

- Balbina, tá cantando! É Império!

Aí que eu cantava mais:

As ilustres personagens 
Prestavam homenagem
Ao par imperial
Desde o ato religioso
Das alianças e do bolo
A valsa nupcial
A orquestra animava a festa
No salão da Corte imperial
Lararárará, lararárará
Lararárará, lararárará
Lararárará, lararárará
Lárarará-larará-rará
Era o samba da Portela. A Portela ganhou, aí o pessoal cantava assim pro
Como é bom ganhar
Como é bom ganhar
Não adianta você chorar 55 Império:

O Império já teve época que tinha ala com 4 pessoas, minha tia botava, essa ala da comunidade foi Tia Eulália que armou a primeira. Nós ganhamos Estandarte de Ouro...

A gente cantava bastante, fazia evolução. Na avenida, o Império com pouquinha gente, a gente ali brincando. Eu digo, essas aí não brigaram nada pelo Império não. A gente ali cantando, bonitinha, todas novinhas, da Serrinha, Congonha, da Grota... Todas as comunidades de Madureira, Cajubira, tudo! Então a ala ficou enorme. Encheu a avenida, a ala da Comunidade, da gente. Eu era a diretora, vinha organizando, fazendo evolução, nessa época, ajudando né? Vim com a roupa de diretora de ala. E elas cantavam, evoluíam, era bom. Aí, primeira coisa: Estandarte de Ouro, ala da Serrinha. Olha, tem história. Samba tem história. Agora, eu gosto muito de muitos sambas, das escolas de sambas. Tem cada samba lindo, não é? Cada uma tem sempre aquele mais bonito, que fica na história. Não sei eu posso falar...

$\mathrm{O}$ da Mangueira. Na época que eu estudava no SENAI, quase em frente à Mangueira, na São Francisco Xavier, eu subia aquela galeria e já estava na quadra da Mangueira. De vez em quando eu ia para lá. Dona Zica, Dona Neuma, as filhas da Dona Zica, também, as garotas, tinha umas que estudavam comigo também no SENAI. Eu gostava de um samba da Mangueira, ainda gosto, vou te mostrar. Olha que samba lindo, da Mangueira, que eu guardei. Está na voz do Jamelão. Eu ia para lá... Não tinha aquela quadra, era pobrezinha aquela ruazinha da Mangueira, e a quadra era aquela quadrinha antiga, agora é que tem a quadra. Mas eram os mangueirenses de coração, minhas colegas, meus colegas, tudo Mangueira, que estudavam lá também... Esse samba da Mangueira, até hoje eu gosto, Primavera (Cântico à natureza). Gente, que samba bonito! Eu escutava cantar, eu cantava também! Muito bonito.

Antigamente, os sambas ficavam na história. Agora você não sabe o sambaenredo do ano passado. Antigamente não, e não tinha nem esse grandão, esse discão.

\footnotetext{
${ }^{55}$ Valença \& Valença (1981, p. 66) contam que Mano Décio da Viola também se desentendera com a diretoria do Império depois do carnaval de 1963, indo para a Portela. A ele atribuem a autoria e a divulgação do deboche Como é bom ganhar, que teria circulado pelas ruas de Madureira em 1964.
} 
Mas era cada samba bonito! Salgueiro, Portela, Mangueira, Império... Aquele samba bonito! Agora as escolas fazem samba mixuruca, horrível. Olha que sambas bonitos, antigos! Ah, que é isso! Agora não tem porcaria nenhuma! Olha que coisa linda, Casa Grande e Senzala... na seresta eles estavam cantando, domingo, eles vieram me buscar. Lá no Irajá, aqui nesse conjunto.

Macunaíma, tempo em que eu ia para a Portelinha, passava pela linha do trem, atravessava... É esse agora, Primavera, muito bonito! Olha aí, o primeiro passo artrose.

Brilha no céu o astro rei com fulguração

Muito bonito, eu saía do SENAI, ficava. É o primeiro passo... Cadê minha muleta? Eu largo ela em qualquer lugar... Mas eu sou firme.

...garoa

Molhando a terra...

Bengala, muleta, tudo a mesma coisa. Será que está lá na cozinha? Olha que coisa bonita:

\section{...magistral}

A primavera...

Menina, eu tenho que voltar ao médico. Terça-feira, eu tenho. Agora eu vou, dia 23, para eles verem, que a prótese chegou... Ele gosta de internar domingo. De manhã a pessoa opera, se não fica lá, fica ruim, você ficar lá. Aí:

...inspiradora de amores

Oh! primavera idolatrada

Sublime estação das flores

Eu sambava na Mangueira!

Oh! primavera adorada

Inspiradora de amores

oh! primavera idolatrada

Sublime estação das flores 
Zé Luiz como integrante da Velha Guarda do Império Serrano. Acervo da família de Balbina de Oliveira Thomé.

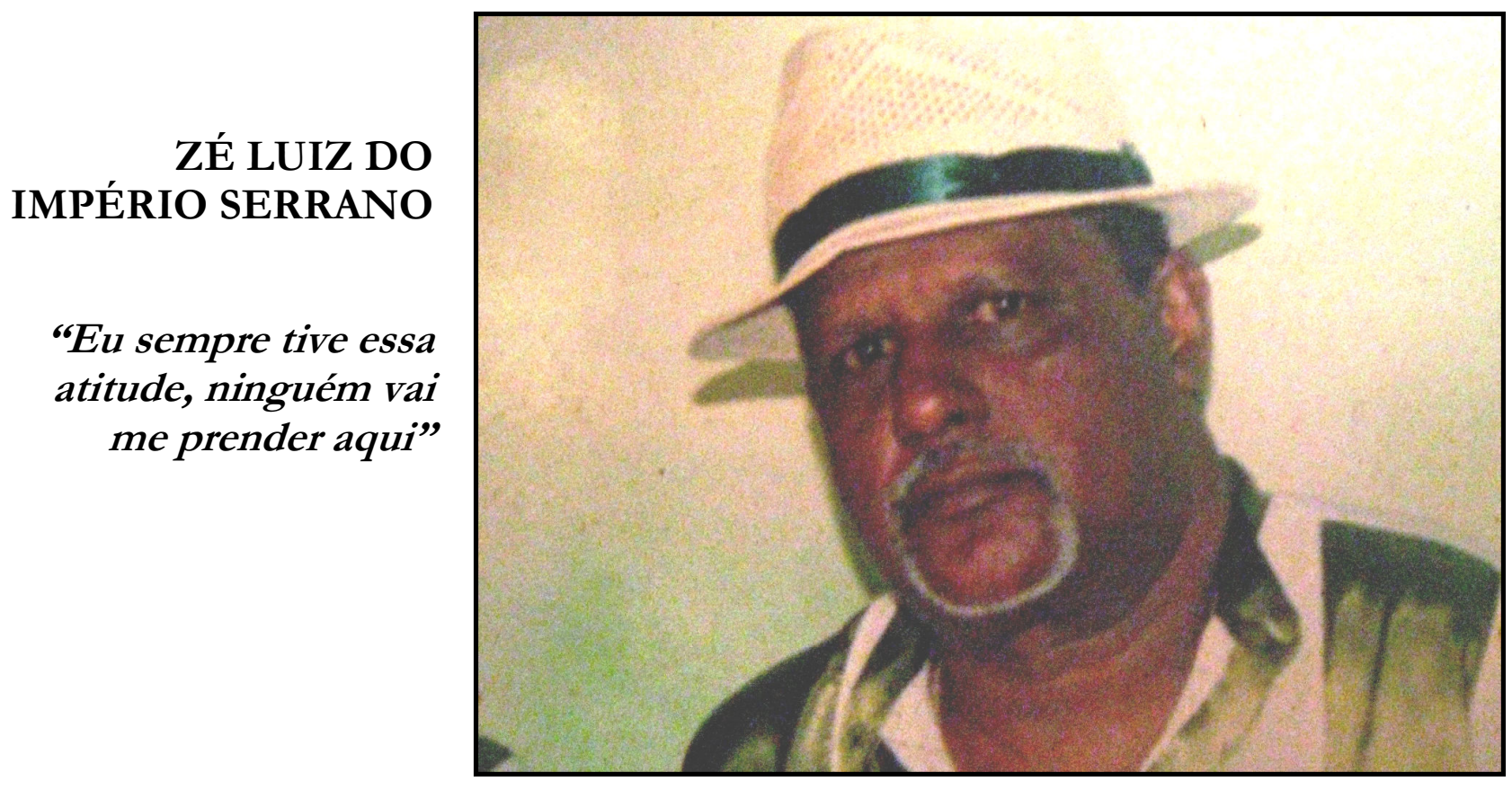

Lugares de Zé Luiz:

1. Santa Teresa (Largo das Neves)

2. Jacarepaguá

3. Pilares

4. Praça Mauá

5. Oswaldo Cruz

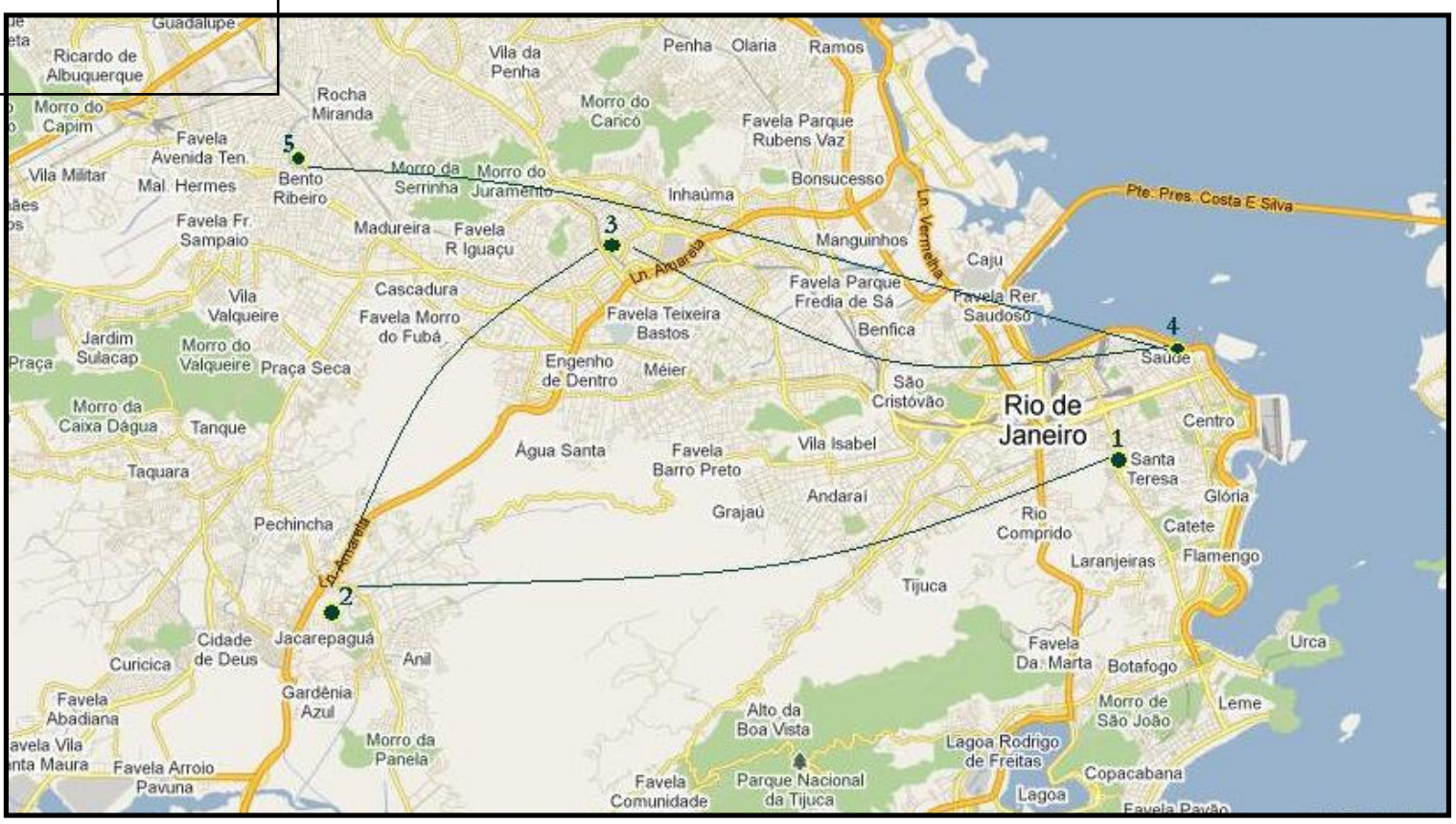


Sou José Luiz Costa Ferreira, Zé Luiz do Império Serrano. Acho importante lembrar minha infância, porque a época em que eu nasci foi justamente a época em que o Rio de Janeiro era a capital cultural do país, em 1944. Nos meus dez primeiros anos de vida, morei em Santa Teresa e era muito próximo ao carnaval do Rio. Era só descer com o bondinho, em cinco minutos eu já estava na Avenida Rio Branco, no Tabuleiro da Baiana ${ }^{56}$, e tudo acontecia ali. Nas rádios, no tempo que antecedia o carnaval, era música pra todo lado: samba, marcha, aquela coisa todinha, Rádio Nacional... Passei por toda essa experiência auditiva. Em casa, meu pai também apesar de eu não ter conhecido bem - era músico amador. Então o meu próprio ambiente de início de vida já propiciou uma ligação muito forte com a música, e eu tenho essa lembrança muito boa.

Meu pai faleceu quando eu tinha 4 anos. Tenho uma vaga lembrança, mas sabia que era músico, tinha bateria em casa. Ele era baterista. Percussionista era um nome novo. Antigamente era músico de um modo geral, não tinha muito essa coisa de percussão, que era mais formação de grupo: grupo de choro... Tinha músico que acompanhava os cantores, mas no máximo era um pandeiro, um tamborim. A coisa percussiva de escola de samba não existia muito, nas gravações. Era outro tipo de samba. A vida em casa... Era uma família pobre, grande, mas aquela pobreza com dignidade. Éramos sete filhos, então até um certo tempo deu para viver em Santa Teresa, mas depois, com a especulação imobiliária, que acontece, de repente foi ficando difícil, os filhos crescendo, também, então tivemos que sair, fomos para Pilares.

Eu tinha estudado na Escola Municipal Santa Catarina, no Largo das Neves, onde nasci; depois passei um semestre na União das Operárias de Jesus, em Botafogo. Quando minha família se mudou para Pilares, fui para o internato. Foi uma experiência muito boa pra mim. Lá estava todo mundo misturado. Eu era interno por causa da minha condição, mas tinha órfão, internos por diversos motivos, filhos de pessoas desquitadas, até classe média. Era bem tranqüilo. E eu tive uma base escolar boa lá, fiquei dos 9 aos 13. Minha mãe achou melhor:

- Vai lá, porque lá você vai aprender uma profissão.

E, realmente, para ter uma disciplina de vida. Até tinha formação técnica, mas eu não cheguei a fazer. Fiz o Fundamental, depois eu vi que, também, não era obrigado a ficar. Aquilo podia me encaminhar para outra coisa, mas eu queria mesmo era curtir futebol, estudar e ficar com a família. E lá era Latim, Francês, coisa que não se dá mais. Você era obrigado a ler mesmo, nem todo mundo tinha saco, mas era obrigado. Eu já gostava de ler, então a obrigatoriedade só me incentivou mais. Tinha também atividades culturais, sessão de cinema... Eram filmes mexicanos e americanos - musicais ou faroestes - em sua maioria. Foi muito legal. Foi lá que eu assisti pela primeira vez Cantando na chuva, lembro bem. A partir dali, tomei um gosto por cinema e literatura que cultivei bastante ao longo da juventude.

Saindo do internato, fui para o subúrbio em Pilares. Dali é que começou realmente a necessidade de trabalhar cedo, pra ajudar, e parei os estudos. Na verdade eu era muito irrequieto. Mesmo com a necessidade, na nossa casa, nunca foi

\footnotetext{
${ }^{56}$ Estação terminal de bondes entre a Av. Treze de Maio e a Rua Senador Dantas, no Centro do Rio, demolida na década de 1960 quando foi construída a Av. República do Chile (Cf. Rodriguez, 2004, p. 154).
} 
exigido que eu trabalhasse, porque eu era caçula, mas eu tinha sempre uma vontade de querer ser independente. Eu olhava os outros, e pensava: "pô, fulano já faz isso...". Então foi muito precoce essa coisa minha de trabalhar, por vontade própria, e foi muito bom, porque fui trabalhando e ganhando meu dinheirinho. Enquanto meus amigos...

Tem uma história que eu sempre gosto de contar, porque na idade que eu parei de estudar, meus amigos continuaram os estudos. E eu tinha que trabalhar, mas era o dono da bola. Trabalhava no horário integral - enquanto uns estudavam de manhã, outros de tarde - e eu sempre sacaneava essa turma, que a bola era minha, eu é que ganhava dinheiro, às vezes eles ganhavam do pai, mas aí eu falava:

- Ah, não vou emprestar a bola, não.

De pirraça mesmo...

Aí eu acabava cedendo e todo mundo saía feliz. Eu sempre fui muito querido pela garotada da minha época por causa dessas coisas. Eu às vezes fazia aquilo, mas depois o coração amolecia, porque sábado e domingo eu estava com eles também. E antes eu fazia parte dessa turma, mas com o negócio de trabalhar eu ficava proibido, pensava "pô, lá vão aqueles sacanas pro futebol, e eu aqui ralando".

Eu era aprendiz de metalurgia, mas era coisa, assim, para ocupar o tempo mesmo. O que aprendi mesmo na oficina não foi a técnica da profissão: os mais velhos me ensinavam sobre o comunismo. Eu não entendia direito, com 13 anos, e eles me davam os jornais - Granma e Voz Operária - para ler. O Sindicato dos Metalúrgicos era muito ativo no Brasil. Fiquei nessa oficina dos 13 aos 17 anos, até a época em que eu ia ter que servir ao Exército. Trabalhei esse tempo como menor, porque naquela época menor trabalhava. Até tive muita oportunidade de outros empregos, mas a oficina era mais perto de casa. Depois servi ao Exército e fiquei um tempo naquelas de "vou trabalhar onde?", sem ter alguma experiência profissional, porque nessa oficina eu não cheguei a ser um profissional, eu era ajudante, e não era o que eu queria fazer. Nessa época, quando fui trabalhar na Mesbla, perto da Cinelândia, convivi com gente do teatro e do movimento político da década de 1960 . Foi quando encontrei uns amigos que tinham sido meus colegas de turma, quando criança, que abriram um curso desses, supletivos.

E eles me descobriram:

- Tá fazendo o quê?

Eu falei:

- Pô, tô trabalhando ali na Mesbla.

Eu acho que era lá.

- Quebrando um galho aqui.

- Rapaz, vamos pra lá, tô com um cursinho lá, não quer estudar?

E meus ex-colegas passaram a ser meus professores. Era uma bagunça, a gente levava um pouco na sacanagem, porque:

- Pô, a aula tá chata, vamos tomar uma cerveja?

Mas foi legal, também, porque eu consegui estudar, e através deles... É até gozado:

- Tem uma empresa nova recrutando pessoal pra trabalhar aí, a Embratel.

Eu confundi Embratel com Brastel, que era uma loja de eletrodomésticos:

- Brastel? 
- Não, é Embratel, não é Brastel, não.

- Pô, vamo lá, então.

Empresa de telecomunicações. Não sabia nada, não sabia o que era telecomunicação, na época; nem eu nem ninguém... Isso era em 1966, 1967. Aí eu entrei em 1968 e fui ver o quê que eram aqueles equipamentos todos, aí é que eu fui entender o que era telefonia, telecomunicações, e o Brasil também estava entrando naquela fase de "Pra Frente, Brasil", coisa dos militares... Os militares foram responsáveis por essa coisa da integração, o Projeto Rondon, as telecomunicações pra todo o Brasil. Porque tinha uma equipe, realmente, de pessoas que eram muito capazes, do Instituto Militar de Engenharia, esse pessoal. Era outro lado do que estava acontecendo. Tinha aquele lado de os militares serem olhados de uma forma pelo momento político, mas teve esse outro lado, da capacidade técnica, das estatais que foram criadas, e a Embratel foi muito importante nessa integração. Fui me aperfeiçoando, fui vendo o que era aquilo, a dimensão que ia ter aquilo de juntar o Brasil através das telecomunicações, aí aprendi tudo e acho que eu dei minha contribuição lá durante um bom tempo.

Fiquei de 1968 a 1997. Em 1996, 1997 eu já sabia que era uma das empresas que iam ser privatizadas. Mas foi legal. Um grande aprendizado. Tenho o maior orgulho de ter trabalhado lá e colaborado, de alguma maneira, para que hoje o pessoal veja televisão lá em Currais Novos, no Rio Grande do Norte, aquelas coisas. Assisti a muita coisa bacana através do meu trabalho, viajei muito... A gente tinha que fazer curso, então eu fui para lugares onde, quando botava a televisão na praça, todo mundo se arrumava para o evento:

- Olha, vai ser ligada hoje a subestação da Globo.

Foi a emissora que teve mais transmissor. No lugar, o pessoal sentava todo na praça, botava uma roupa bonita pra ver o Jornal Nacional e a novela, era um negócio bacana. E peguei um tempo em que eu viajava e o pessoal mandava trazer uma carta para entregar, porque não tinha telefone, tinha só um Posto Telefônico no lugar, então tinha que marcar hora pra falar. Era comovente... Você vê que uma coisa que eu nem sabia o que era, quando eu estava dentro eu vi a importância social daquilo. Depois, com a privatização, acabou aquele romantismo, mas foi muito bacana.

Quando eu me casei, já estava trabalhando. Casei um pouco tarde, que eu tive bastante tempo de zoar muito por aí... E a música também, porque eu trabalhava, mas já tinha gravado, então consegui conciliar, sempre bem aconselhado e vendo como é que era esse negócio de música. Nunca larguei o trabalho, então tinha condição de curtir as duas coisas. Até porque, às vezes, a pessoa tem uma visão de o sambista ser um cara que ganha muito dinheiro, mas aquilo é muito efêmero. Às vezes até ganha mesmo, igual jogador de futebol, e a pessoa pensa que aquilo vai durar a vida toda, mas está despreparada. Eu vi muito acontecer isso, aquele sucesso rápido e a pessoa depois não saber administrar aquilo, que um dia podia acabar. Então eu sempre fui muito cuidadoso, mas curti muito essa coisa de música. E também continuei a trabalhar. Com uns 30 e poucos anos é que eu fui me casar, constituir família.

Morava sozinho, sempre morei. Eu tenho muita irmã, e de vez em quando:

- Tu tá fazendo o quê?

- Não, tô passando uma dificuldade... 


\section{- Vem morar aqui.}

Mas nunca fui. Tinha que morar sozinho e, quando eu fui trabalhar nesse lugar já passei a ter uma condição melhor. Não se ganhava pouco; trabalhar numa estatal, naquela época, como a Embratel, a Petrobras... Quer dizer, tinha um padrão dentro do qual dava para viver bem... Eu morava sozinho, morei aqui e ali, até que eu me fixei em um lugar maravilhoso, de que tenho saudade até hoje: a Praça Mauá. Morei ali bem perto da Pedra do Sal ${ }^{57}$. Ainda está lá o prédio. Fui morar ali por comodidade, também, porque a Embratel era ali. As empresas de telecomunicações, Embratel, Telemar, IBM, tudo era ali naquela região. Fiquei alguns anos lá, até... Conhecer Dona Vilma. Começamos a namorar, ela morava aqui e eu morava lá, sozinho, aí eu falei:

- Ah, vamos juntar...

Foi quando nasceu a minha filha Aida, e nós viemos morar aqui em Oswaldo Cruz. Moramos do lado de lá da linha do trem primeiro, e depois eu consegui, com a aposentadoria, vir pra cá e... Já estava a casa apertada, com dois galalaus. São dois filhos, um menino e uma menina. Jorge nasceu no dia de São Jorge, 23 de abril, e me inspirou a fazer Malandros Maneiros, parceria minha com Nei Lopes. Não tem gente que tem musa? Pois Jorge foi meu "muso". Viemos pra cá, tive a oportunidade de investir no meu sonho - o sonho de todo mundo era ter uma casa, não é? Construímos aqui, estamos aqui até hoje, adoro o lugar... Mas às vezes fica grande demais. Minha filha já não mora mais aqui, se casou, é formada em Jornalismo. Então, estamos por aqui, e é muito legal. Um imperiano morando em Oswaldo Cruz.

Isso no início era muito brabo, era gozado. Brabo, porque... A Portela no auge, e o Império também, eram das grandes escolas de samba, e eu ficava até meio envergonhado de sair vestido de Império Serrano, porque tudo aqui era Portela. Então era meio gozado, ter um imperiano numa rua cheia de fundadores, filhos de fundadores da Portela. Um imperiano era um estranho no ninho. Mas eu sempre tive muita amizade, eu adoro aqui, todo mundo. E o que existia era uma disputa, mas era um negócio saudável. Depois, acabava o carnaval, o Fuleiro era compadre do Nozinho, que era irmão do Natal, que era... E o outro era tio de não sei quem que morava lá. Até hoje existe esse parentesco muito grande entre, pelo menos, essas três escolas: Império, Mangueira e Portela. Esse conjunto habitacional que tem aqui, veio muita gente da Mangueira morar aqui, então virou terra de sambista mesmo.

Em Madureira, Oswaldo Cruz, se misturam as três bandeiras, numa relação bastante curiosa fora do carnaval. No carnaval não, cada um vai lá brigar pelo seu, mas é uma disputa bastante amistosa. Ainda mais agora, que essas três escolas sofrem um processo de exclusão, com as mudanças no carnaval. Acabou o samba de quadra - antes era terreiro, mas depois que a primeira escola cimentou e botou iluminação, passou a ser quadra. Veio carnavalesco, samba-enredo, que começou a dar dinheiro, e isso gerou uma situação de exclusão que fez com que elas se tornassem muito mais unidas. Até porque, coincidentemente, são as únicas que não têm aqueles patrocínios. As escolas sofrem muito com isso, e as comunidades

\footnotetext{
${ }^{57}$ Monumento histórico e religioso no bairro da Saúde, perto do Cais do Porto do Rio de Janeiro, por onde se pode subir para o Morro da Conceição. A Pedra do Sal foi tombada em 20 de novembro de 1984, originando-se o processo de texto do historiador Joel Rufino dos Santos (Cf. verbete "Pedra do Sal" na página Wikipedia, http://pt.wikipedia.org/wiki/Pedra_do_Sal, último acesso em 27 de dezembro de 2010).
} 
também abandonam um pouco. A Portela, por exemplo, perdeu toda essa comunidade, porque houve um movimento de fora pra dentro... Então a comunidade se afastou da escola. A Portela não desfila mais em Oswaldo Cruz. Era um hábito muito saudável de todas as escolas: no dia seguinte ao carnaval, fosse qual fosse o resultado, a escola desfilava no bairro. Então muita gente perdeu esse encantamento, e quem veio dirigir a escola não teve mais respeito pela comunidade. A Mangueira e o Império ainda têm, queiram ou não, porque a comunidade toda mora... Embora a sede do Império fique aqui, os componentes são da Serrinha, Vaz Lobo, Congonha, Cajueiro, São José e todos aqueles espaços ali. A grande massa de pessoas que freqüentam Mangueira e Império ainda mora por ali.

Eu tinha um tio por afinidade que foi fundador do Império, o tio Zacarias. Quando eu morava em Pilares, ele levava meus dois primos fantasiados para a mãe, que era uma baiana fundadora da Unidos da Tijuca. Ele já era imperiano, porque trabalhava no Cais do Porto, mas a mãe dele era tijucana e saía na Unidos da Tijuca. Ele levava os sobrinhos lá, para mostrar as fantasias dos moleques que saíam na ala mirim da escola. As fantasias eram guardadas com o maior segredo, para que outras escolas não imitassem, mas tinha esse hábito de levar para tomar a bênção da avó. Eu achava aquilo bonito e já era amigo da família.

Onde eu morava tinha os Caprichosos de Pilares. Era uma escola tradicional, também, que eu freqüentava, cheguei a ser diretor, mas o coração mesmo era imperiano, então eu vinha era para Madureira. Já freqüentava o Império, mas nunca entrei para nenhum segmento da escola... Só entrei depois, para ser compositor. E nunca gostei muito desse negócio de disputar samba-enredo, meu negócio era mais samba de meio de ano. E pela minha própria convivência e atividade, o pessoal já começava a me convidar, fui começando a gravar e... maneira...

- Pô, entra aqui pra Velha Guarda, vem fazer parte aqui, ajudar de uma outra

Ter outras funções na escola. Claro, sendo compositor, mas as escolas de samba, já naquela época, não tinham muita atividade recreativa, como samba de quadra, porque passou a ser tudo em função de samba-enredo... A freqüência nas escolas de samba começou a ser só a partir de junho, voltada para o samba-enredo. Mais um motivo para cada vez afastar mais o pessoal da comunidade. Não fazia mais sentido você ir para as escolas de samba, porque sabia que tudo estava voltado para o enredo ser escolhido. Começou aquele negócio de disputa de samba-enredo. Mas eu sempre estive lá, desfilando na velha guarda, embora não tão mais presente. Só assim, quando tinha uma festa... Eu acho muito bonitas as festas da velha guarda, uma vai visitar a outra, essas coisas. É um hábito...

- Olha, hoje é festa na quadra de não sei quem.

Então elas se visitam - a velha guarda tradicional, que eu acho muito mais importante até do que a Velha Guarda musical. A Velha Guarda musical é importante pelo registro... Mas essa velha guarda, ela é muito mais forte, muito mais... Quer dizer, veste mais a camisa, você vê, os senhores e as senhoras fazem questão de estarem muito bem vestidos... É muito bonito.

Para entrar na velha guarda tem que ter uma idade, é até natural, se tem idade na escola é porque também tem uma idade de vida, não é? Acaba sendo a mesma coisa. Eu saio há 30 anos no Império, então eu não tenho 30 anos de idade, já devo ter 
50, então naturalmente aquela pessoa já vai se encaminhando, porque já não vai sair numa bateria... A outra já não, a ala das baianas, por exemplo, é uma ala que está entrando em extinção, porque não tem mais baiana com velocidade para disputar, desfilar numa correria de samba. Então algumas forçam a barra, mas é uma coisa muito delicada, porque passam mal realmente, e as baianas velhas não vão deixar de beber a cerveja delas também, não vai ficar ninguém fazendo concentração, como jogador de futebol, para o desfile. Pelo contrário, elas enchem a cara mesmo de cerveja e vão desfilar, então tem escola em que já estão até recrutando pessoas mais novas pra saírem de baianas. Senão vai acabar, porque é uma exigência que as escolas tenham alas de baianas, mas cada vez se perdem componentes e espaço também, porque a ala de baiana hoje já não é o foco da escola de samba.

Hoje todo mundo quer ver é bateria e rainha de bateria. É o que interessa à mídia. É tudo a mesma coisa... Tudo a mesma coisa não, eu digo isso porque é o que o turista quer ver. A ele não interessa que a ala tal tenha 50 anos, ou que a baiana, ou que aquele lá é o Seu Zé das Couves, que fez o primeiro bloco para virar escola... Isso aí só vai lá no release para divulgação, mas nem o cara que está comentando o desfile sabe disso, nem a televisão e nem principalmente o patrocinador, o que está pagando pelo horário, estão muito interessados nesse negócio..

Com relação à velha guarda ter passado para a parte de trás dos desfiles, existe aí uma controvérsia. Não é bem assim, não, porque a velha guarda vinha como comissão de frente da escola, como quem diz:

- Eu estou aqui apresentando o que eu fiz.

Vinham os veteranos da velha guarda. Isso era a função da velha guarda. Mas aí começou a valer ponto a comissão de frente. Mas se vem todo mundo sendo a mesma coisa, vai ter que dar 10 pra todo mundo, não é? Então aí virou um negócio, igual carnavalesco, apareceu lá coreógrafo, porque está valendo ponto aquilo, então a velha guarda não foi lá pra trás porque quis, nada disso. Inventaram que valia ponto, que estava muito igual. E eu concordo, se mudou a escola de samba eles tinham que mudar algumas coisas também. E para a velharia, pelo contrário, foi muito bom. Eu, por exemplo, se eu estou lá atrás eu já bebi todas as minhas cervejas. Pelo menos no Império Serrano tem esse tipo de comportamento, aquilo ali é pra você desfilar, claro que vai ter o respeito, mas existe a brincadeira.

Essa formalidade que ia ter lá na frente, de todo ano você ter que vir sério, sendo o primeiro, aí depois é que você vai poder beber sua cerveja, vai poder brincar... Pô, é justamente o contrário, eu acho, do que os velhos queriam. Pela seriedade da história, sim, começou assim, os educadores, como Paulo da Portela, uma pessoa mais exigente, queriam assim. A Portela tem essa postura até hoje, de ser uma escola rígida em termos de comportamento. Império e Mangueira, não, o pessoal é bem liberal, então essa coisa da velha guarda ir lá pra trás foi legal, e bem representada, que hoje essa velha guarda tradicional vem em cima de carro, e eles gostam de brincar, então acho que tem esse lado também. Quer dizer, perdeu uma coisa, essa representatividade de ser o primeiro a ser mostrado, mas em compensação ganhou lá atrás, de brincar, porque o cara mesmo fala:

- Eu gastei um dinheiro...

Que eles gastam, e é linho, não é barato, não. Pelo menos no Império Serrano, ninguém queria outra coisa, a não ser vir bem vestido. 
- Pô, botei isso aqui pra quê? Pra ficar 15 minutos aí dando até logo? Não vou curtir?

O pessoal reclamava um pouco disso, então eu acho que é legal ter essa posição de vir lá atrás. Porque virou uma coisa obrigatória, que ganha ponto, então, já pensou? Um velhinho lá de 80 anos ter um negócio ali, cair, e...

- Perdeu ponto!

Então houve um senso, uma discussão, que foi favorável a isso. Eu não acho que o que está aí melhorou em nada. Virou circo, aquilo ali para mim não quer dizer nada, se o cara sair de dentro de uma caixa... Aquilo não é samba, é outro espetáculo. Vale para ponto e é bonito, tem certas coisas que são, plasticamente. Hoje o que interessa é o tamanho do carro, a rainha de bateria, a melhor comissão de frente, isso são os quesitos mais respeitados. Sou contra, mas vou fazer o quê?

No Império Serrano já existia uma Velha Guarda musical, formada por Tio Hélio, Fuleiro, os fundadores... Nilton Campolino, Carlinhos Vovô, essa foi a primeira formação. Já existia, mesmo no tempo da Velha Guarda da Portela, mas o pessoal do Império não é muito disciplinado para essa coisa. Tinha qualidade, mas não tinha alguém que chegasse:

- Olha, vamos organizar...

Sabe? Os velhinhos de lá eram mais rebeldes que os velhinhos de cá. Então, quer dizer, chegou um tempo que o pessoal começou a cansar, não teve grande duração. E depois, alguns dos remanescentes dessa Velha Guarda... Campolino, que era uma espécie de guru para mim - eu andava muito com ele e ele gostava muito de mim - falou:

- A Neide voltou agora...

Que foi uma ex-presidente que o Império teve.

- ...e eu falei com ela que a nossa Velha Guarda acabou, tá todo mundo aí, e a gente quer formar de novo, quê que tu acha?

Nesse tempo eu já era velha guarda, Wilson das Neves também... Aí, falou comigo, com Wilson:

- Então vamos recrutar aí...

E o difícil foi isso, recrutar as pessoas que tinham uma tradição, uma história com a escola, e mais ou menos alguma habilidade para cantar. Foi muito complicado, porque não tinha realmente, essa... A Portela já vinha há anos, com essa formação. E já tinha acabado esse negócio de pastora, justamente por causa do samba-enredo, já não existia mais samba de quadra. Eu tive que recorrer a pessoas mais antigas e gravações pra formar um repertório, porque nem as pessoas se lembravam dos sambas, de quem eram os autores... Mas nós conseguimos, depois de algum sacrifício, começar a ensaiar, e quando veio, também, veio logo estourando. Conseguimos fazer um $\mathrm{CD}$, com muito sacrifício, porque ninguém aqui do Rio ajudou - a verdade é essa. Foi preciso o pessoal lá de uma ONG, a Cachuera! (Associação Cultural Cachuera!), lá de São Paulo, se interessar pelo projeto.

A Velha Guarda do Império Serrano só tem um disco. Tem uma gravação de show ao vivo, da primeira formação, mas não chegou a sair em disco, era o programa Ensaio... E também algumas participações. $O$ resto tem shows, tem disco do Campolino com Mestre Aniceto, Fuleiro com Mano Décio da Viola, algumas coisas assim, mas como formação, Velha Guarda mesmo, não. Só tem esse que foi feito há 
alguns anos, e distribuído pela Biscoito Fino. Ainda deu tempo de chegar numa hora... A da Mangueira, já tinha sido criada, não sei, mas acho que sim. Depois da da Portela.

Só faltava a gente mesmo, e... Salgueiro, que também não teve muita chance de formar uma boa Velha Guarda, porque o Salgueiro é uma escola mais nova, de 1953, quer dizer, muitos elementos da Velha Guarda do Salgueiro - Geraldo Babão, Noel Rosa de Oliveira, Anescarzinho - não tiveram tempo... E nós não tivemos essas pessoas da primeira formação, mas tivemos o Campolino, que não participou do disco - não teve tempo, também -, mas deu uma orientação, e as pessoas que estavam ali também tinham história, o filho do Mestre Fuleiro, eu, Ivan Milanez, Balbina, Wilson das Neves, todo mundo tinha uma história na escola. E ficou legal, o repertório, foi legal de montar. Como o Império tem muito samba-enredo famoso, nós tiramos os sambas-enredo, porque já tem muito registro, então nós pegamos mais os sambas de terreiro. E aí houve um consenso muito legal, com os sambas menos conhecidos e mais bonitos - opinião minha. Eu falei:

- Olha, é melhor gravar isso agora, porque os outros já foram muito gravados.

Tanto é que um dos sambas mais conhecidos do Silas, que é de terreiro, Meu Drama, nós não gravamos. Houve lá umas briguinhas de vaidade, porque ninguém podia, dos componentes, botar samba seu. Era para registro mesmo do que foi. Porque a gente está aqui, vivo, ainda grava, mas esses sambas não... Era pra ser uma história, realmente. Aí houve uns choques de vaidade, entrou um samba do Aluízio Machado como marca da geração nova, mas todo o resto foram sambas só do pessoal da antiga mesmo. E como era eu que dirigia, eu dei minha opinião de que não era legal, que ia começar a ter briga de interesse.

- Meu nome tá aí, meu samba tá aí...

E isso a gente sabe - eu pelo menos sei - que isso não dá dinheiro. O disco é caro... Naquela época nem estava tão próximo, mas eu sabia que o CD ia acabar, que o mercado fonográfico ia ficar cada vez pior, mas as pessoas não entendiam isso, era a vaidade de ter um samba no CD da Velha Guarda. E eu falava:

- Isso é bobagem, se eu quisesse, tem samba meu aí, eu ia botar, o Wilson das Neves também, mas prefere fazer disco dele próprio, de carreira. Acho que fica muito mais legal a gente fazer isso, pra não ter esse tipo de conflito entre a gente mesmo... Agora, no show sim, no show, cada um, além de cantar os sambas do disco, da Velha Guarda, pode cantar seus sambas.

Aí foi dada essa idéia, e todo mundo:

- Não, realmente fica mais legal.

Paulão 7 Cordas, também, que foi o produtor, concordou e passou isso pro pessoal. De repente eu fazer uma regravação de Todo menino é um rei, não tem nada a ver, embora Roberto Ribeiro tenha sido imperiano, mas tiraria toda a característica da história que a gente queria contar. E ficou muito bacana, embora caro, que na Biscoito Fino os discos são caros... Mas não deixa de ser legal, não é? Nós agradecemos, realmente, a quem botou o dinheiro para montar o disco, que foi a Cachuera!, lá de São Paulo, que fez o investimento. E a Biscoito Fino, houve um interesse, porque, queira ou não queira, eles têm um acervo de qualidade. Mas as pessoas reclamam:

- Não vejo o CD de vocês em lugar nenhum

Eu falo: 
- Vai pela internet, porque nas lojas vai ser difícil encontrar.

E tem também a pirataria, porque não adianta. Zeca Pagodinho mesmo já falou com a gente:

- Pô, minha maior vontade era que o meu disco custasse R\$ 5,00. Não custa isso e ainda é pirateado.

Então, quer dizer, tem esse lado, de que raramente alguém tem o CD original da Velha Guarda do Império Serrano por isso, vai ter quem curte mesmo a coisa... Mas o lado ruim é esse, que não ficou o que a gente gostaria de atingir, a massa do público. E também o apadrinhamento: ninguém se ofereceu pra ser o mecenas do Império Serrano, embora tenha a Dona Ivone Lara, o João Bosco, tem pessoas que a gente sabe que são imperianas, mas não teve alguém, assim, que comprasse o nosso barulho. Nós não tivemos a nossa Marisa Monte da vida, para fazer isso aí, mas tudo bem, a gente está lá, satisfeito com o que foi feito.

Eu comecei a sair da Velha Guarda do Império pelo desgaste, normal, e já antevendo esse negócio de substituição, porque todo mundo tem opinião no grupo. Eu já estava vendo que nós perdemos Toninho Fuleiro, perdemos outra pastora, a Tia Nini, aí o grupo foi diminuindo, mas a formação básica estava boa. 11 pessoas está de bom tamanho, mas ia ter que ter uma renovação, e pelas opiniões que vinham, aparecia um negócio de interesse, de amizade...

- Chama fulano.

- Pô, mas fulano?

Aí eu vi que ia começar a entrar em choque, porque a minha liderança ali era natural, não foi nada imposto. Tanto é que as pessoas no início aceitavam, como o Wilson das Neves, mas o Wilson:

- Não, eu também não tenho muito tempo...

Aí a coisa ficou toda na minha mão, e é muito chato você não querer ser ditador, mas às vezes tem que dizer:

- Chega, então vão fazer vocês lá...

É que nem o Romário falou:

- Pô, sentei, tô aqui, você entrou agora e já quer vir pra a janela? Não, vamos puxar o currículo... Então vamos respeitar um pouco!

Já estava começando esse tipo de confronto que eu não queria. Porque algumas pessoas achavam que fazer parte da Velha Guarda já era um status que se dava a eles, e é, mas não passaram pela coisa como deveria ter sido historicamente:

- Ó, eu comecei daqui, fui, fui...

Comecei a ver, assim, não chegava a ser insubordinação, mas:

- Não, a gente sabe fazer...

Quer dizer, começou a se criar um desgaste normal, e eu, não querendo defender nem atacar ninguém, ficava na minha. E sempre tinha que ir, porque era eu que organizava, e era um dos vocalistas. Sobravam poucas pessoas que faziam isso, a gente não tinha uma banda constituída, nem a Portela tem, ninguém tem. Então tinha que ter músico de apoio para fortalecer o show, e isso tudo é dinheiro, aí o pessoal já comentava:

- Pô, o cara que vai tocar violão vai ganhar a mesma coisa que a gente?

Aí eu pensei "é, já chega, está na hora. Já deu desgaste, então eu vou parar por aí”. E deixei. Esse negócio da substituição é justamente isso, porque vai passar por 
esse tipo de problema também. O cara vai ser convidado e vai ficar na expectativa de que vai fazer... Hoje mesmo saiu no jornal, eles gravaram com Zeca Pagodinho, uma música com a Dona Ivone... Todo mundo lá, é legal. Isso só me traz orgulho de ter contribuído para isso, mas eles têm que saber usar isso de o Zeca ter chamado a Velha Guarda. Ele chamou porque é uma música da Dona Ivone, então tem que saber que a instituição é muito mais forte do que essa formação de Velha Guarda. Porque é Império Serrano, o nome está acima de qualquer coisa. Foi muito difícil passar isso pra eles todos. E eu já estava um pouco cansado, queria ter tempo pra cantar meus sambas por aí. Mas foi legal, foi muito bom até aqui.

Essa Velha Guarda musical se formou há dez anos, por aí. Eu sou muito cético em relação a essa terceira geração. A não ser que se faça um disco com a formação nova, ou com alguns outros elementos, mas obedecendo à proposta inicial, porque ainda tem muita coisa para ser apresentada, como teriam a Portela e a Mangueira também.

Tantinho, por exemplo, com Xangô da Mangueira, Nelson Sargento, Jurandir da Mangueira, faziam parte da primeira formação da Velha Guarda da Mangueira, mas eles saíram justamente porque começou a ter esses choques de opinião, de visão. Depois Tantinho conseguiu fazer dois discos maravilhosos sobre a Mangueira, que não tinham nada a ver com a Velha Guarda. Então há muita coisa aí, eu posso gravar um disco cheio de samba... Até queria fazer isso, não só do Império, de samba que eu sei que - não é nenhuma pretensão - só quem vai saber sou eu, Tantinho, Sérgio Cabral, Ricardo Cravo Albin ou Elton Medeiros, porque tem pessoas que estão aí que são desse tempo, conhecem samba, entendeu? É coisa de tradição oral mesmo. Mas tem muita coisa ainda para ser gravada e registrada, então o trabalho sobre isso não pára nunca. Agora, sobre formação, aí fica mais complicado, porque, nem todas as pessoas vão ter esse mesmo tipo de observação que a gente tem.

As mulheres, na velha guarda, sempre tiveram uma participação importante. O Império eu acho que é até inovador nisso, também. A velha guarda do Império não tinha mulheres, e acho que foi a primeira a ter. Eu acho legal, porque várias vezes acontece de serem da mesma casa, mulher e marido, e os dois serem de velha guarda. Uma sai lá, o outro aqui, então por que não fazer parte do próprio segmento ali? E a mulher, claro, tem um papel, em qualquer setor, mas ainda mais no samba... Ela é a mãe do samba, realmente, ela tem a história bonita da cozinha, dessa coisa da arrumação, que eu via, da quadra... E não é um serviço depreciativo, era uma coisa que elas também gostavam de fazer, botar a escola bonita, enfeitar, ter uma participação, e além do mais tem o lado artístico disso, que era o canto.

As pastoras eram muito mais importantes que qualquer coisa, para um compositor. Com a voz delas, com o tom de voz, que tinha que ser delas, aquele tom pra cima, era que se engrandecia o samba do compositor. Então nenhum compositor ia querer chegar na quadra e ver que não tinha pastora. Essas pastoras é que iniciaram isso tudo aí, são hoje a velha guarda, são as matriarcas do samba, como Dona Ivone, que é a grande representante que tem aí, como foi Dona Neuma, Tia Zica, Tia Zezé do Salgueiro, Tia Alice, Doca, Tia Eunice, essas pessoas com as quais eu tive o prazer de conviver. É uma pena que tenha que ter essas duas velhas guardas, uma musical, que cria realmente um tipo de inveja feminina... A masculina já é, claro, mas a feminina, realmente, se cria um negócio: 
- Eu canto mais do que ela!

- Eu sambo mais do que ela!

Essas coisas todas... Mas só pode ter duas, três, e não houve nenhuma votação. E aí é meio complicado, mas nada que depois, quando a coisa está bonita, não se entenda que foi para o bem da agremiação. Acho que todas elas gostariam de estar lá também, até por uma questão de direito, de ter feito parte, de ter lutado... A única coisa que eu lamento é que eu acho que todo mundo da velha guarda tinha que estar lá, em cima do palco, tanto homem como mulher, fazendo parte daquele momento. Mas, de qualquer maneira, se elas lá no fundo sentirem, elas estão sendo homenageadas, estão fazendo parte daquilo.

E a coisa da religião, no Império, tem toda a relação, a batida da bateria do Império, por exemplo, é totalmente diferenciada, justamente pela religiosidade que existia, que sempre existiu na Serrinha, nas comunidades, em Congonha, Tamarineira, Cajueiro... Era macumba, jongo, candomblé, e essas coisas todas envolvem tambor, não é? Então tudo isso tem esse tipo de batida que na escola, no samba, você já vê o andamento, a característica da escola. O Império tem muito isso, e todas as escolas aqui, do Rio, têm alguma ligação com santo. O do Império é São Jorge, que por incrível que pareça é mais famoso que o santo oficial da cidade, que é São Sebastião. Desculpa, mas São Sebastião fica no segundo plano, porque São Jorge, agora, virou até moda.

São Jorge sempre foi o santo venerado, pelo Rio de Janeiro, pelo carioca, e principalmente pelo Império, então há essa coisa do envolvimento do santo, bem representativo mesmo, dentro da quadra, essa veneração. Além do preceito de as pessoas serem dedicadas àquele culto ali, àquela coisa. $\mathrm{O}$ Império continua mantendo essa religiosidade dele, um pouco distribuída entre umbanda, candomblé e um pouco do jongo, que não chega a ser uma religião, mas é um tipo de procedimento de quem vem mais do norte do Estado, aquela coisa mesmo de escravo, bem africana, realmente... E essa mistura deu no Império Serrano, então você sente na batida, no tipo de andamento, muita africanidade.

Outras escolas também são como o Império, mas não têm essa espontaneidade porque são escolas que passaram a ter dono, a verdade é essa, entendeu? E não sou eu que estou falando, está aí, é público. São Paulo tem uma coisa muito engraçada: as escolas têm dono, mas porque têm dono mesmo. É a escola de Seu Nenê, porque foi Seu Nenê que fez no terreno dele, e vai passando de pai para filho. Isso é legal, mas nem esse tipo de administração dá certo. Mas pelo menos lá tem dono, não houve uma apropriação, de alguém que veio e comprou, como aqui. E dizem que foi o próprio sambista que deixou isso acontecer, mas não é, é que a coisa foi tomando um gigantismo. E na verdade o artista, não é porque seja pobre, seja favelado, é porque ele não sabe tomar conta disso. O cara não pensou: "eu vou me tornar administrador, pra tomar conta da minha escola de samba." Não estava nem aí. Mas os mais sabidos, eles já vinham administrando alguma coisa, então sabem como é que toma conta de dinheiro, ainda mais esse tipo de dinheiro, assim, mole. Então tomaram conta, realmente, e os sambistas falaram:

- Legal, minha escola é campeã, tá bonita, né?

Nessa ilusão eles foram... 
A postura do Império Serrano vem de um outro tipo de fundação. Seu Paulo da Portela era um disciplinador, queria todo mundo alinhado, para valorizar o sambista, e isso é legal, e em qualquer escola existe. Agora, o tipo de cabeça do sambista imperiano é um diferencial, que os outros também tinham, mas passaram a não ter. Aí a gente já vai cair num outro problema, do negro, de ser subserviente e achar que chegou um cara que sabe mais do que ele, então o cara é que é o bom, e ele, coitado, não sabe nada, então precisa ser obediente a ele, essas coisas. Vai cair nisso, claro.

Mas, vamos parar o discurso por aí e deixar apenas como uma rebeldia normal que a escola tem, pela sua própria história. Candeia, embora tivesse sido seguidor de Paulo da Portela, se rebelou contra justamente aquilo, que ele não queria ser escravo de ninguém, então fez a escola de samba Quilombo, da qual eu também participei, sou fundador, junto com Nei Lopes, Wilson Moreira, Luiz Carlos da Vila, Flávio Moreira, Waldir 59 e Rubem Confete, formamos a ala de compositores do Quilombo.

Quer dizer, eu sempre tive essa atitude, ninguém vai me prender aqui. Se eu achar que adoro isso aqui, a cor da camisa que eu estou defendendo, é legal; se não estou achando legal, eu dou palpite mesmo, vou achar que não é assim. Acho que tem que ter atitude. 
Noca da Portela em frente à sua residência. Acervo pessoal da autora, dez. 2010.

NOCA DA PORTELA

“Os sambistas precisam de escola. A escola precisa de sambistas"

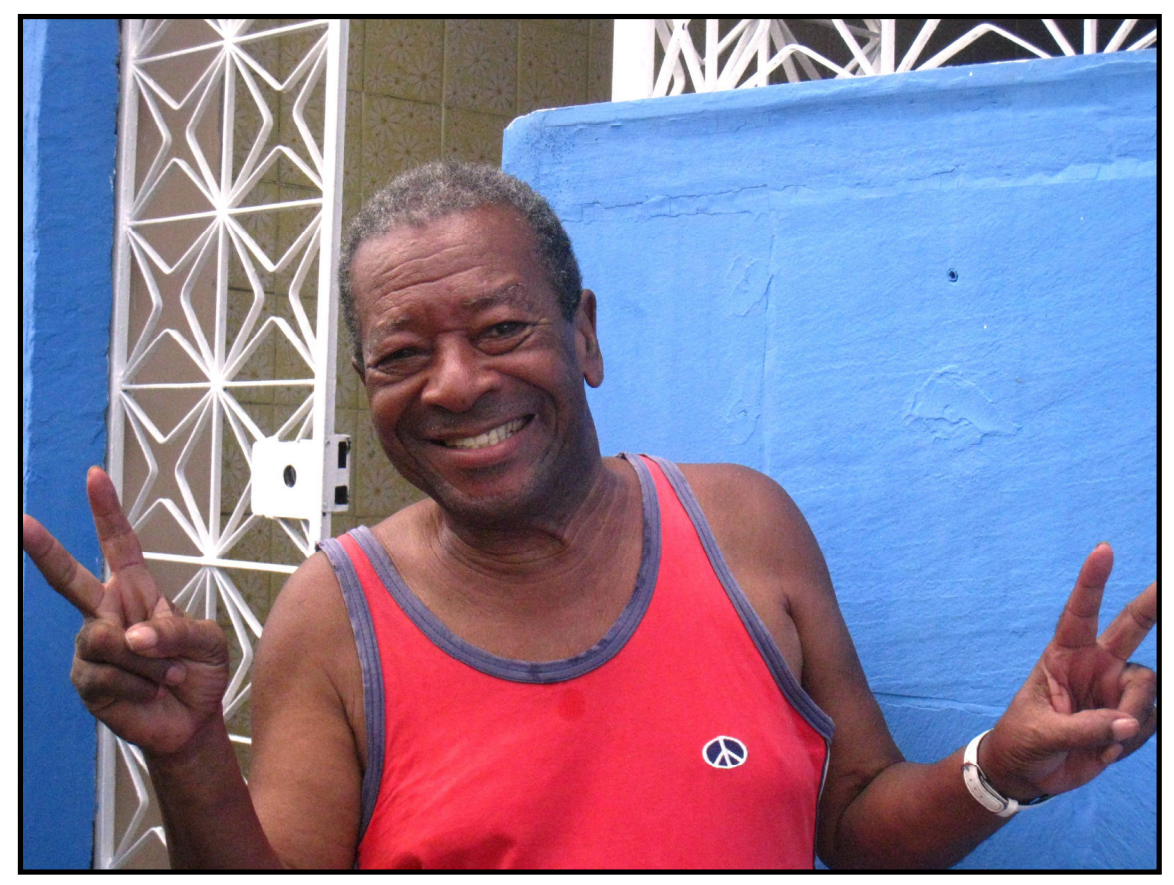

Lugares de Noca da Portela:

1. Leopoldina, $\mathrm{MG}$

2. Catete, Rio de Janeiro, RJ

3. Praia de Botafogo

4. São Cristóvão

5. Engenho Novo

6. Engenho de Dentro
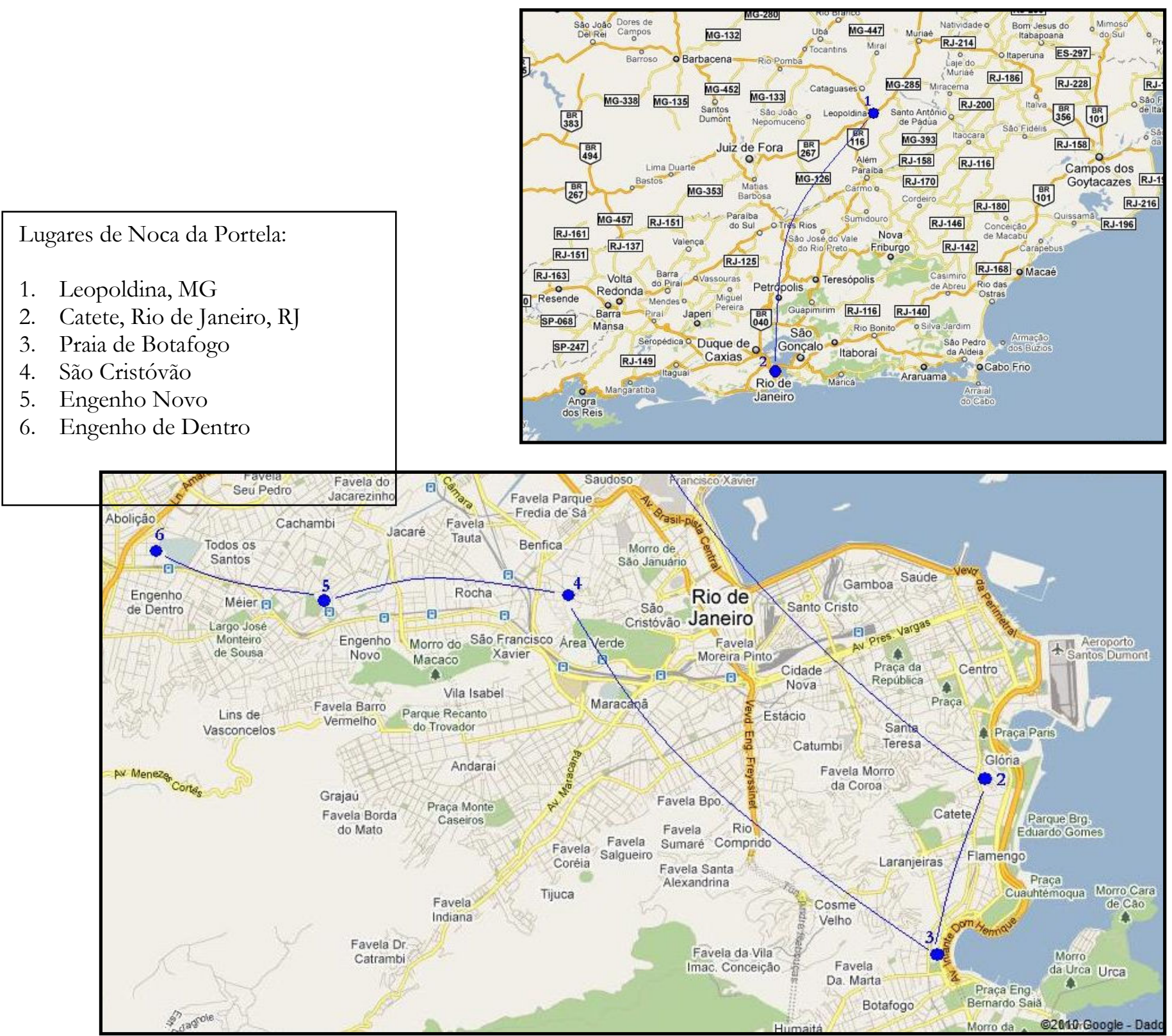
Entrevista demorada... Primeiramente é um prazer muito grande, a gente estar aqui de novo, depois de oito anos, dando continuidade a essa entrevista, não é? A minha história são 55 anos de samba, 77 anos de vida. É uma história de lutas, de respeito às pessoas, de talento; o ser humano não chega a lugar nenhum se não tiver talento. É uma das coisas principais de quem quer fazer uma escola de samba... A vida já é uma escola, e o samba também é uma escola, onde você aprende os procedimentos, para saber se expressar diante das pessoas, respeitosamente, então eu me orgulho da minha trajetória e de fazer todo o possível pra que essa história seja contada. Gosto de ser um cara do bem, me orgulho de ser um sambista do bem. E é a velha guarda do samba que traz isso adiante, esse sacrifício. O samba é uma profissão de guerreiros. Tem que ter vontade de ser sambista, porque se for ser sambista sem nenhuma vontade também não vai a lugar nenhum.

Eu não sou carioca, sou de Minas Gerais - Leopoldina, Minas Gerais - e fui morar no bairro do Catete, no Rio de Janeiro, ainda criança, com 5 anos. Ali tinha uma escola de samba e com 14 anos eu concorri pela primeira vez, e não é que eu ganhei? Não é que eu tirei nota 10? Minha primeira nota $10 \ldots$ E aí eu descobri realmente que tinha talento para aquilo.

Morei em Botafogo também, participei do bloco Foliões de Botafogo. Era a maior ala de compositores de qualquer agremiação. É! Seus componentes foram pessoas ilustres, todos tinham brasões: Geraldo Babão, Anescar, Elton Medeiros, Paulinho da Viola, Mauro Duarte, Noca, Walter Alfaiate, Niltinho Tristeza, Adélcio de Carvalho, Cachinê. Era, assim, uma ala de compositores de deixar todo mundo orgulhoso. Tinha que ter interesse da mídia em mostrar isso, para a jovem guarda que está aí saber que numa ocasião, em tempos idos, existiu um grupo desses, que agora é escola de samba. Aliás, foi a pior coisa que eles fizeram, transformar aquela família em escola de samba. Como escola de samba eles não... Não acontecem. Escola de samba tem enredo, tem alegorias, tantas coisas, tem quesitos que vão ser apresentados no desfile, e o bloco não, era só a alegria e a motivação, cantavam uma porção de sambas lindíssimos...

Tristeza, por favor vá embora...

Era de lá. Foram tantos sambas lindos, que aconteciam ali e depois iam pro disco, e quando virou escola de samba, sumiu, foi por água abaixo. Agora tem um projeto, em Botafogo, para que volte novamente o bloco Foliões de Botafogo, e vamos tentar fazer uma nova ala de compositores, convocando grandes compositores, para reviver essa grande escola. A história do samba é linda, é cheia de idéias e amizades, coisas de pessoas do bem que têm essa capacidade de captar isso, colocar isso em prática.

Antes de eu ir para a Portela, fui morar em São Cristóvão, com meu irmão mais velho, que tinha uma casinha lá. E lá tinha a comunidade do Tuiuti. Lá é que eu comecei ser feliz, porque conheci a minha esposa, a Dona Conceição, e já estamos com 55 anos de casa. Ela é uma parceira, companheira da melhor qualidade, que sempre me ajudou; eu agradeço, deveras, a Dona Conceição, por ser esse homem consciente, esse chefe de família, essa pessoa que respeita a família primeiramente e os companheiros, os parceiros. Nós tivemos quatro filhos lá e agora a família está crescendo, já tenho seis netos, bisnetos e coisa e tal. Mas lá existiam três escolas de 
samba: Paraíso das Baianas, Unidos do Tuiuti e uma agremiação chamada... Brotinhos. Aí eu me reuni com a rapaziada:

- Ô, cara, por que três agremiações num lugar só?

Igual ao que acontecia no Salgueiro, na Serrinha... Mas se fizesse uma só, ficava fortalecida e a comunidade não se dividia. Assim fizemos, em 1955, e sou um dos fundadores do Paraíso do Tuiuti. Essa agremiação me deu muita alegria, fui ganhador de muito samba-enredo lá.

Naquele tempo, aqui no Rio de Janeiro, tinha a Festa da Penha, no mês de outubro, e cada agremiação montava a sua barraca. Infelizmente acabou, mas era uma grande festa... Deveriam voltar essas coisas boas, não é? Precisava progredir, mas preservando. Não custa nada, mas as autoridades, infelizmente, não têm essa capacidade de reconhecer que a cultura é uma coisa muito importante para qualquer povo. E preservar as coisas culturais, não só do Rio, mas desse país, é importantíssimo para as novas gerações. O novo Brasil, essa juventude que está aí, que serão os Nocas de amanhã, os Monarcos, os Nelsons Sargentos...

Numa Festa da Penha, um ano desses, o Paulinho da Viola passou na barraca - a comunidade ia toda para a barraca da escola, era uma espécie de um piquenique, sob a égide do samba. Paulinho então passou lá e eu estava cantando o samba que ele tinha ganhado na Portela em 1965. Só fez um, ganhou um e a escola foi campeã e ele nunca mais fez samba-enredo para disputar. Então, eu estava lá cantando e ele aí parou, ficou me olhando - eu já trabalhava na feira, inclusive a mãe dele, Dona Paulina, era minha cliente. Ele foi se chegando, com o Chiquinho, o irmão:

- Oi, você não é o... Aquele... Noca, lá da feira?

- Sou eu merrmo!

- Quê que tá fazendo aí?

- Aqui é minha comunidade, o Tuiuti, rapá.

- Puxa vida, só tem samba bonito, tava ali de longe, escutando... Agora, como é que você aprendeu esse... Esse samba aí, lá da Portela?

- Primeiro, eu adoro a Portela. E tem um feirante amigo meu, que tá aqui também, chamado Matraca. Ele é diretor de harmonia lá da Portela. Ele me ensinou esse samba e nós estamos cantando, em homenagem à Portela e agora a você, que tá chegando aqui agora. Rapaziada, o Paulinho da Viola tá aqui!

Ele novinho... Era Memórias de um Sargento de Milícias:

Era nos tempos do Rei, quando aqui chegou

Um modesto casal, feliz pelo recente amor

Leonardo...

Um samba lindíssimo esse do Paulinho, tinha 48 linhas e todo mundo cantava com uma alegria.... Agora os caras fazem samba com 22 linhas, mas ninguém canta mais porque não faz sentido. É rir pra não chorar. Não tem melodia, não tem sentido, não tem poesia, não tem nada, aí só serve pro cara passar no desfile, depois na quarta-feira de cinzas, alguém pede:

- Canta o refrão do teu samba, da tua escola?

- Ih, rapaz, esqueci, não lembro!

Mas antigamente não era assim. E virei amigo do Paulinho, não é? Então, nessa época a Portela tinha a maior ala de compositores e as pessoas indicavam pro Seu Natal:

- Seu Natal, no lugar tal tem um grande sambista, lá, compositor maravilhoso! 


\section{E Seu Natal:}

- Manda buscar, lá, pra Portela, trazer pra nossa Academia...

O Paulinho ia fazer a peça Carnaval para Principiantes com Paulo José, Dina Sfat, inclusive o Elton Medeiros estava. Aí, como sempre toquei um violãozinho razoavelmente bem, ele me chamou para tocar violão na peça, com grandes sambistas - Mauro Duarte também estava, e outros grandes sambistas, inclusive do Tuiuti. Então, fizemos essa peça em 1966, aí depois o Paulinho, conversando com o Seu Natal, falando das coisas lá da Portela... O violonista era o Jorge do Violão, mas ele adoeceu, ou coisa parecida, e o Paulinho falou:

- Tem um cara lá no Tuiuti, rapaz, toca um violão bem! Compositor maravilhoso.

Aí o Paulinho veio e me convidou. Aí no dia que eu fui apresentado, lá na Portela, cheguei na Portelinha, lá em Oswaldo Cruz, na Estrada do Portela nos fundos, e o presidente da ala era o... Candeia. Mas antes o Paulinho me levou pro Seu Natal:

- Seu Natal, aqui, esse é o Noca.

- Ah, tá legal, e de onde é que esse menino é?

- É lá do Tuiuti.

- O que é isso?

Aí eu - ha! - eu falei:

- Tuiuti é uma comunidade onde tem uma escola que eu sou fundador, chamada Paraíso do Tuiuti.

- Mas você chama Noca do Tuiuti?

- Não, só Noca.

- Então de hoje em diante você vai ser o Noca da Portela.

O Candeia, que era o presidente da ala dos compositores, veio e disse:

- Pra fazer parte, você vai ter que provar que é compositor. Tô com tempo, até de noite, só vou sair daqui na hora que você fizer um samba. Toma, pega papel e caneta e vai lá.

Aí eu fui e meia hora depois eu tava de volta com dois sambas feitos.

- Cê já voltou?

- Tá aqui.

E mostrei os dois sambas pra ele, era Portela Querida e um outro, ele aí ficou me olhando, desconfiado, só de lembrar já começo a rir...

Eu sou portelense, e me sinto feliz

Quem fala mal da Portela não sabe o que diz

Aí, você imagina, começar logo com um samba desses, louvando a escola? Depois disso eu fui fazer meu primeiro samba-enredo só dois anos depois, em 1968. Seu Natal escutou e disse:

- É esse mesmo, nem precisa fazer disputa.

Seu Natal metia medo em todo mundo, mas assim mesmo eu pedi que a disputa fosse feita normalmente, porque achava aquilo injusto, não é? Seu Natal ficou muito contrariado:

- Ó, se você perder na quadra, com o samba, você vai ser responsável pela derrota da Portela!

- Quê isso? 
Nessa época eu já morava lá em São Cristóvão. Aí o Cabana, que era compositor do samba concorrente, chegou, alugou dois ônibus, encheu a quadra lá da Portela, deu dinheiro a eles... Quando nós chegamos não tinha nada, não tinha banda pra entrar, só entramos os compositores. Aí tomamos um massacre na quadra que eu nunca tinha visto aquilo. A quadra inteira cantou o samba deles e o nosso perdeu, do jeito que o Seu Natal tinha previsto. Eu nem queria voltar lá, com medo do Seu Natal. Mas aí eu tinha feito o samba Portela Querida... Depois de um tempo começou a tocar na rádio, virou primeiro lugar na parada, e no mesmo ano o Paulinho da Viola lançou Foi um rio que passou em minha vida. Então, a Portela com duas músicas na parada.... Seu Natal ficou feliz e acabou passando. Essa é uma das alegrias, mais alegrias que tristezas, que eu tive. E essa é a história da minha ida para a Portela.

Depois disso... O samba Portela Querida, por exemplo, é um samba de quadra. Infelizmente não está mais presente nas escolas essa tradição. Samba de quadra era uma aprendizagem pro cara ser realmente um grande compositor. Tanto é que grandes sambas da Portela, que foram gravados pela Beth Carvalho, pela Alcione, pelo Paulinho da Viola, pelo Martinho da Vila, pelo Roberto Ribeiro, foram sambas de quadra da escola de samba. As pessoas esqueceram esse patrimônio, essa riqueza cultural que é o samba de quadra. Pra você fazer o samba-enredo, nas escolas dos tempos idos, você tinha que passar pelo samba de quadra. E através do samba de quadra, tinha conhecimentos da escola. Quase ninguém nem sabe disso na escola:

- Qual o orixá que comanda a sua bateria?

É...

- Qual o orixá que comanda a sua escola?

Os caras, os meninos de hoje não sabem isso. Eles fazem sambas agora que contrariam o orixá. Sabe o que acontece? O samba atravessa na avenida, a harmonia vai pro espaço, porque o cara não pediu licença, não sabe nem o orixá que comanda a bateria. Todas têm seu orixá, você sabe disso? Toda escola tem o seu orixá, toda agremiação, e você aprende essas coisas fazendo samba de quadra. Toda bateria tem o orixá e o compositor nem sabe disso, por não ter mais o samba de quadra, que era uma espécie de vestibular, não é? Agora não tem mais isso, então o cara entra na escola de samba totalmente perdido, aí quando ganha é um desastre na avenida, porque contrariou o orixá... A comunidade toda sabe quem comanda. E tem acontecido isso, por não ter essa preliminar para o compositor ter intimidade com a agremiação, entrar nessa família. O samba é coisa de família! Vem da Tia Ciata, aquela família dos primeiros sambas, com o Ismael, que fez do Estácio a primeira escola, uma família, e isso tem muito a ver com a negritude. O samba era negócio de negros, todos nós sabemos disso. E tinha seus rituais, suas mandingas ou coisas parecidas. A pessoa que entra num lance desses tem que ter um mínimo de conhecimento, para que possa desempenhar bem o seu papel nas suas composições, entendeu? Então, a história do samba tem coisas que têm que ser ditas, as pessoas têm que tomar conhecimento dessas coisas, mas pouca gente tem conhecimento.

O que mais eu posso dizer? A Velha Guarda da Portela, com todas as outras velhas guardas, é a maior referência. Porque a intenção dessa Velha Guarda foi mostrar os grandes compositores da Portela que não tinham oportunidade de se mostrar. O Paulinho da Viola, que é o patrono, começou a juntar os grandes mestres. 
Eu aprendi muito com a Velha Guarda, quando eu cheguei lá estavam se organizando, então eu tive a honra, o prazer e a felicidade de conhecê-los no auge da sua força de compor. Eu aprendi muito, virei - modéstia à parte - um compositor consagrado, até porque eu prestava atenção, e aprendi realmente, com Chico Santana, Alberto Lonato, Manacéa, Monarco, Casquinha, e tantos outros da Velha Guarda, que me ensinaram bastante. Serei eternamente agradecido a eles. Eu mesmo não participo dos shows da Velha Guarda da Portela, mas é claro que estou entre os compositores que têm história na escola. O meu negócio é sozinho, se eu fosse para a Velha Guarda, seria pelo ideal. O Monarco me acha muito novo, não quer me passar o bastão. Mas eu também trabalho pela escola, levo o nome dela para frente.

Surgiram outras Velhas Guardas, mas, por exemplo, na Mangueira, não fizeram a Velha Guarda que deveria ser feita, com Cartola, Nelson Cavaquinho, Carlos Cachaça, Xangô, Darcy da Mangueira, que já se foram. Também no Salgueiro não formaram uma Velha Guarda com Anescar, Geraldo Babão, Noel Rosa de Oliveira, Zuzuca, e tantos outros. Eles não conseguiram formar essa Velha Guarda que seria a referência legítima da escola. Com exceção da Velha Guarda do Império, que realmente é formada por compositores - o Aluizio Machado, o Ivan Milanez, compositores realmente - a Velha Guarda das outras escolas de samba é denominada Velha Guarda show: são músicos, mas aí não tem referência, é outra coisa. E a Velha Guarda da Portela é o espelho, é a referência, como a do Império também, agora. Até hoje, a Velha Guarda da Portela, sem desfazer das demais, é a mais conceituada, que ainda tem lá compositores como o Monarco, o Casquinha, estava agora vendo o Serginho Procópio, do cavaco, todos compositores ainda representantes do bom elenco de grandes compositores da Portela.

Mas está começando a ficar difícil, os grandes compositores estão falecendo e a gente está, assim, sem opção, sem saber como é que vamos dar continuidade a isso. Por isso é que vem a preocupação de formar grandes compositores. Nós - eu, Monarco, Casquinha - nos preocupamos com essa falta, estamos felizes com o Serginho, filho do Osmar do Cavaco, e outros compositores que estão agora lá na Velha Guarda. São meninos que a gente tem que incentivar e prestigiar, pra que eles se tornem também grandes compositores, como nós somos. Ali parecia uma Academia, só entrava outro quando morria um componente, existia regulamento, mas agora a gente está começando a se preocupar porque não estão aparecendo sucessores à altura da história que esses grandes mestres formavam.

Os grandes compositores eram revelados pelo samba de quadra, que acabou. Então a juventude, a jovem guarda do samba não tem referência. Eu, quando cheguei na Portela, tive que bater continência pra mais de vinte - hoje quem entra na escola não bate continência pro Noca, pro Monarco. Entende? Chegam, como se diz, acabaram de subir no ônibus e já vão querendo sentar perto da janela. É! E ainda tiram onda:

- Eu ganhei do Noca!

- Ganhei do Monarco!

Ao invés de dizer:

- Pô, tenho o maior orgulho, disputei uma final com Seu Noca, com Seu Monarco, e eu ganhei, mas tenho que respeitar a obra deles. 
Não, eles ficam com marra. Ainda tem alguns que dizem que a gente não está com nada, já era, já fomos, e coisa e tal, somos do passado, não do presente. Porque eles não aprenderam que tem um samba de quadra, onde eles têm de saber que existe orixá, que comanda a bateria. Isso são coisas de... Negritude, porra! Sem preconceito de cor - o samba é de todos, do branco, do preto, do mulato, do amarelo - agora, tem que ter talento. Tem que ter sabedoria pra compor um bom samba, tem que ter autocrítica, porque antigamente não tinha jurado. Hoje eles colocam o jurado para escolher o samba, já com a nota dada, o cara senta ali fazendo papel de boneco, nas escolas de samba atuais. Já vem com o presidente falando assim:

- O samba que tem que ganhar é esse.

Aí você vai lá, faz o papel de palhaço... Antigamente era o contrário, o compositor chegava a dizer pro presidente:

- Não, o melhor samba é do fulano. Eu tenho amor à minha escola, eu quero o bem da minha escola. Meu samba é bom, mas o do fulano de tal é melhor.

Era assim. Aí ficam esses sambas que todo mundo canta até hoje, não é? Memoráveis sambas. Os deles não... É assim que a banda toca. Isso me deixa muito preocupado. Tem que voltar imediatamente o samba de quadra. Ontem, no festival de samba de quadra, escutamos sambas lindíssimos, bem feitos, com letra, com poesia, com... E a maioria dos compositores era de escola de samba! A Portela? Passou o rodo! Ganhou o primeiro, o segundo e o terceiro. Onde tinha dinheiro, a Portela levou tudo. Só tinha prêmio pra três, os três foram da Portela, e o presidente tem que tomar conhecimento disso, as pessoas da escola:

- Tá vendo, samba de quadra, os caras foram lá, raparam tudo!

E a gente jogando esse tesouro fora... Entendeu?

Se existe ruptura entre a Diretoria e a velha guarda da escola? Em todas elas! A velha guarda não representa mais nada para a escola de samba. As velhas guardas não são escutadas, não têm direito a opinião. Isso é um absurdo, é perigosíssimo, porque vai virar só negócio de Sapucaí, acabou ali e não tem mais nada, vai ter que trocar o nome. Colocar S/A, como fez o samba do Império. Sociedade Anônima. Não é uma escola de samba? O nome é escola de samba. Escola, quer dizer, é o lugar onde você aprende, não é verdade? Hã! Como é que você não aprende mais nada, você já entra, cai de pára-quedas, se diz compositor, você não é contestado, você não é jurado, você não é obrigado a dar demonstração, realmente, de que tem talento pra exercer essa profissão de compositor... Então, não é mais escola de samba. Essas coisas têm que ser faladas. Infelizmente a Globo, quando chama os caras lá, não chama pessoas com essa coragem, com essa sabedoria, eles não fazem isso, eles levam os caras lá, sem nenhum conhecimento de causa... Então, reclamam:

- Ah, escola de samba não tem mais!

E os garotos:

- Pô, o quê que eu vou fazer na escola de samba? Eu vou pro meu funk lá, que lá estamos unidos!

E nós vamos perdendo essa essência do grande compositor, e daqui a dez, vinte anos, não tem mais representante digno.

Dificilmente, sem base, o cara avança. Pra tudo na vida tem que ter base, até pra construir uma família! Mas tem que saber o que é uma família, pra poder administrar essa família, não é? Ensinamento, colocar o amor diante de todas as 
coisas. Se você chegar no escuro, aí... Impor uma coisa que não existe, se você não aprendeu o básico, como é que pode? Se não tiver o básico, como é que pode dizer que é alguma coisa? Como é que eu vou dizer que eu sou um intelectual, se eu não tive essa base? Eu não sou um intelectual, eu sou uma pessoa que tem sabedoria, eu sou uma pessoa politizada, a escola da vida me deu ensinamentos extraordinários, entende? Eu posso debater e dialogar com qualquer pessoa que chegar e, modéstia à parte, me sair bem. Mas eu tive um ensinamento, eu tive escola. E a escola de samba ensina à beça, inclusive a compor. A maioria dos sambistas nasceru com o dom de compor, mas tem que fazer esse básico, e esse básico é na escola de samba.

Lógico, tem que harmonizar a letra! Ter noção de rimas, e se possível rimas ricas. Tem que ter uma noção musical, pra fazer uma melodia correta, para não criar um choque entre duas notas, entendeu? A poesia bem rimada, com sabedoria; precisa saber usar as palavras. Como ensinava o meu mestre Ataulfo Alves:

- Noca, primeiramente, pra fazer um bom samba, você tem que descobrir uma frase que todo mundo quer expressar, mas não sabe como. Um exemplo: "Amélia não tinha a menor vaidade, Amélia é que era mulher de verdade". O samba todinho tá nisso, nessa frase só.

- É mesmo, mestre, puxa vida, que sabedoria.

O Noel Rosa falava coisas bonitas, apesar de ser um intelectual, mas era um cara popular, o povo entendia o que ele dizia, hein? Aquilo ele não aprendeu na faculdade, não! Aquilo ele aprendeu na escola da vida. Saber usar as palavras, saber usar a divisão, saber um assunto que interessa a todos; a música não é nada mais do que um assunto que interessa a todos. Quer ver um prato cheio, aí? Falar sobre o mensalão do DEM. Quer prato melhor de que esse? Hein? Dizer que tem grana na meia, na calcinha e na cueca... Ha-ha! É só você dizer:

- Uma grande idéia: Eureka!

Pronto, já começou, já começou a valer:

- Tem grana nessa meia, na calcinha e na cueca.

Pronto. Entendeu? Então música é uma coisa de jogo de palavras, você joga com as palavras, aí depois você vai ter que ver a melodia, então você tem que ter um mínimo de noção melódica. Depois: você tem que correr atrás das rimas, se possível for, das rimas ricas, palavras pouco usadas. Vai lá no dicionário, e tal, e vê essa palavra, o quê que significa, aí você vai achar palavras bonitas, que dão o mesmo sentido, e vai chamar atenção. Tem palavras que a maioria do povo nem sabe que existe, mas vai olhar no dicionário e tem. Apesar de que os compositores de dicionário mesmo são os da elite, que o compositor de samba cria palavras. Cria verbos. Eu fiz um verbo pro Cacique de Ramos:

Olha, meu amor, esquece a dor...

Vou caciquear

Sou caciqueando, são verbos que a gente cria. Essa palavra caciqueando não existia, mas virou verbo: vou caciquear, você caciqueia, ele caciqueia, e por aí afora. Eu fui campeão cinco anos lá no Cacique, garota! Disputei seis anos, ganhei cinco. Agora é que eu não tenho ido, porque o Cacique perdeu aquela razão de ser, não é? O Cacique saía com 10 mil caciqueandos pela rua, depois foi caindo, foi caindo, aí Beth Carvalho levantou o Cacique, através do pagode, e parece que eles estão se recuperando novamente, correndo atrás da tradição, fazendo isso que está faltando, 
que é samba de quadra. Quarta-feira, está tendo samba de quadra lá no Cacique. Quer dizer que eles estão resgatando aquele básico.

Modéstia à parte, além de ser um cara politizado, um compositor politizado, eu sou um cara preocupado com o futuro do samba. Hoje eu tenho coisas, essa casa é minha, comprei. Foi o samba que me deu. Tudo isso que está aqui, essa família grande, essa coisa toda, tudo isso, esses troféus, essas medalhas, está faltando espaço na parede. Eu não posso ser ingrato ao samba, sabia? Eu não posso virar as costas pro samba, em momento algum. E tem que lutar, apesar das ingratidões, da falta de respeito, das sacanagens que existem, eu não posso virar as costas, tudo que eu consegui na vida foi o samba que me deu, entendeu? $O$ sambista precisa ser, realmente, um defensor do samba, e primeiramente tem que ser politizado. A política está em todos os lugares das nossas vidas, não é? Dentro da sua casa, no seu trabalho, na condução que você pega, tudo... No ar que você respira tem política, e sem inspiração você não canta. Então, essas coisas infelizmente faltam ao sambista, a consciência do que o samba representa pra todos nós. Eu costumo dizer, estou com 77 anos, puxa, mas bem de saúde. Se o samba alimenta o meu corpo e a minha alma, eu sou um cara saudável. Dificilmente eu vou ao médico, quando eu vou lá, ele diz assim:

- Tá fazendo o quê aqui, rapaz? Abre vaga pra outro, você tá ótimo!

Eu digo:

- Doutor, você não tá me enganando não?

- Não, que nada, rapaz, você tá beleza pura, vai embora!

Então isso é uma felicidade, a saúde é uma coisa preciosíssima do ser humano. Não adianta você ser milionário, riquíssimo, coisa e tal, e faltar o principal, que é a saúde.

A casa do samba, eu estou conseguindo isso, com o Presidente da República. Eu fiz músicas para as duas campanhas do Lula. No fim do ano passado, Dona Marisa Letícia fez uma surpresa no aniversário dele. Aí me convidaram, eu cantei um monte de músicas e no fim, quando me apresentei, o Lula ficou emocionado. Depois passamos mais de três horas conversando.

- Noca, sabe que a gente até que é parecido? Eu vim também de longe, no pau-de-arara, o caminhão quase tombou...

Aí eu falei assim:

- É, Presidente. A única diferença é que eu vim de Leopoldina andando quase o caminho todo a pé!

Aí ele perguntou como estava o samba. Eu falei que não estava muito bom, porque o Governador Sérgio Cabral não me atendia. E o que eu queria era pedir para construir a casa do samba. Na mesma hora o homem passou a mão no telefone, aquele direto, assim, ligou pro Cabral, dizendo que eu não estava conseguindo ser atendido. O Cabral disse que não recebeu nenhum recado, mas aí o Lula passou pra mim, e eu mandei na lata:

- Pode demitir a secretária e o assessor, porque eu tô deixando recado e não recebo resposta.

Eu queria estar lá do outro lado pra ver a cara do Cabral! No dia seguinte tocou o telefone, queriam marcar uma audiência, mas disseram que ele não podia atender. 
O Prefeito Eduardo Paes também levou esporro:

- Poxa, Noca, podia me ligar direto, mas falar com o Presidente?

- Eu tentei, mas ninguém me atendeu...

Aí eu consegui um pouco mais de $\mathrm{R} \$ 80$ mil para organizar apresentações de samba no Terreirão e na Lapa. É pouco! Quando vem o gringo pagam mais de um milhão! Eu aí fiquei de pagar $\mathrm{R} \$ 500,00$ para cada um que cantasse algumas músicas. O negócio é que espalharam um boato que eu tinha R\$ 600 mil na mão e estava repassando só $\mathrm{R} \$ 500$ para cada um. É de uma ignorância isso! Agora estou até querendo desistir e devolver o dinheiro, é mais fácil.

A casa eu não quero dizer que é minha, não quero essa casa pra mim, mas eu falei brincando com o Presidente, ele perguntou:

- Como é que... E o samba?

Eu digo:

- Presidente, o samba não tem casa.

- Como assim?

- Não, é que o samba mora andando.

Ha-ha! E ele:

- O quê? Ô Noca, o quê?

- Presidente, o samba mora andando.

A gente conversando e ele na hora ligou pro Sérgio Cabral:

- O sambista vai ter.

Eu estou lutando pelo sonho do Cartola, que eu tive o privilégio de ser amigo dele e trabalhar com ele. Também o Ataulfo, o Nelson Cavaquinho, o Candeia, todos os sambistas do passado sonhavam que nós teríamos um dia uma casa, onde nós pudéssemos nos reunir. Fazer os nossos velórios, fazer nossas festas de aniversário, fazer o samba ser forte e unido. Parcerias, reivindicações, para isso tudo tem que ter uma casa... Você está me entrevistando aqui, dentro da minha casa, você não pode fazer isso na rua, andando, não pode, tem que dar uma parada, coisa e tal. Eu mandei inclusive um e-mail pro Presidente, mandei: "Presidente, obrigado, em nome do samba, o atendimento do Governador foi... O melhor possível, ele disse que vai se empenhar pro samba parar de morar andando, vai ter a sua casa, e é um compromisso que ele assumiu. Depois o senhor fortalece aí". Duvido que ele já não tenha ligado, com aquela voz rouca, falando assim: pessoal?

- Escuta aqui, companheiro Cabral, como é que tá a casa lá, do samba, do

Ele cobra, com certeza ele cobra. Então, com isso, a minha missão já está cumprida, não precisa fazer mais nada pelo samba, eu entrego:

- Olha aí, a casa tá aí, é de vocês, fiquem aí agora, se organizem, reivindiquem uma rádio pra vocês aqui dentro, um canal de televisão, uma gravadora, um selo pra vocês poderem gravar as músicas de vocês, que eu já lavei minhas mãos, minha missão já está cumprida.

Claro que eu vou lá prestigiar, mas não quero ser dono de nada, não quero ser candidato a nada. Eu quero sim, que a História conte isso no futuro: "Existiu no ano tal um cidadão chamado Oswaldo Alves Pereira, mais conhecido como Noca da Portela, que a vida inteira foi de luta pelo bem-estar do sambista, pelo respeito que ele tem pelo sambista, pelas coisas que um sambista necessita". Acho que esse vai ser 
o prêmio que eu vou ter na vida, realizar o sonho de muitos outros companheiros que se foram. Com toda a certeza, a torcida lá no alto está grande pra que isso aconteça realmente, está todo mundo:

- Até que enfim, chegou um cara consciente das nossas necessidades.

Está lá o Cartola comentando com o outro:

- Tá vendo, aquele menino? Olha lá, tá segurando a nossa bandeira, lá embaixo...

O pessoal antigamente se encontrava na Penha, mas acabaram com isso. Realmente é pra dispersar, isso é feito com intenção, com toda a certeza. Numa festa em que todos sambistas eram solidários, onde você encontrava nêgo da Mangueira, do Salgueiro, do Império, todo mundo se abraçava e contava novidade, comia no mesmo prato, bebia no mesmo copo, entende? E eles acabaram com isso. Então, precisa disso, de uma casa, para que nós possamos voltar a ter esse ajuntamento de pessoas de todas as escolas, de todas as cores, de todas as idades, e um se preocupando com o outro, não é?

O caso do Walter Alfaiate, por exemplo. O Walter está no hospital, com a maior dificuldade pra pagar as despesas hospitalares que ele teve e ainda está tendo. É um desespero danado, a filha dele desesperada, coisa e tal... Nós, nessa casa, temos que ter uma conta bancária nossa, uma caixinha, onde cada um botasse um dinheirinho do seu show, pra quando acontecesse isso... Mas está aí o sambista sendo enterrado como indigente. Precisa reivindicar a aposentadoria, como nós que estivemos em Brasília agora, eu Nelson Sargento, Délcio Carvalho, Wilson Moreira, Agenor de Oliveira e outros, as pessoas antigas, as cantoras também, pedimos uma sessão no Senado, para reivindicar, foram todos os senadores.

Eu, graças a Deus, sou malandro, sempre paguei direitinho, coisa e tal, sou organizado. Minha assistência médica, pago todo mês, meu INPS não pago mais... Hoje eu estou aposentado, eu posso ficar sentadinho aqui, sem fazer nada pra ninguém, e tranqüilo, quando eu subir pro segundo andar, furar a fila, está tudo certo aqui, entendeu comadre? Não vou querer vaquinha pra me enterrar, pra pagar os custos médicos. Mas a maioria dos sambistas, infelizmente, por não ter essas coisas de um alertar o outro, de um conversar com o outro:

- Ô cumpadre, como é que tá a sua aposentadoria? Ô, meu irmão, é melhor... Tu já tá... O sucesso não dura eternamente, a saúde também não é eterna, só Deus tem esse poder, nós estamos sempre numa luta aí...

Então vamos começar, e se tiver uma casa dessas, também vai ter disco, vai poder colocar no roteiro da Riotur. Lá na Inglaterra, lá em Portugal, no mundo inteiro, através do governo, o pessoal tem que saber que tem uma casa de samba aqui, tradicional. Bota a casa do samba aí muito longe:

- Quem é que freqüenta a casa?

- Monarco, Noca, Délcio Carvalho, Nelson Sargento, todo mundo está lá!

É um atrativo, não é verdade? Então, como é que se faz isso? Se organizando. Tendo consciência do que representa o samba pra todos nós. Mas o pior dessas coisas todas, quando você consegue uma oportunidade como eu consegui, rapaz, isso deixa a gente indignado, eu não vou machucar meu coração por causa disso, mas, jogar uma oportunidade de ouro dessas fora? Eu consegui recurso pra fazer um concurso novo e o pessoal começou a dizer que eu ia levar por fora... É de uma burrice do 
tamanho de um elefante, de uma baleia! São cabeças totalmente sem nenhuma noção do que é o trabalho. Normalmente são pessoas recalcadas que saem falando isso, não são pessoas que têm consciência do que representa uma coisa dessas. Mas a gente vai continuar lutando, o velho Noca é filho de Xangô. Xangô é justiceiro e não brinca em serviço - hã! É meu orixá, tem lá na Portela: São Sebastião, Ogum, o Império é o quê? É Ogum. São Jorge... Não estou certo? Os caras têm que bater tambor, antes de bater o pé tem que bater tambor, pra respeitar as entidades que tem na escola.

Um dia a Clara Nunes encomendou pro Candeia um samba que falasse da alma feminina. Ele aí fez a melodia de Mil réis e me telefonou:

- Ô Noca, esse negócio de alma feminina eu tô fora. Você bota a letra, que o meu lado feminino é sapatão!

Eu ainda falei:

- Poxa, mas você tem feminino até no nome...

- É, mas você também tem, e o seu é tão poderoso quanto o masculino.

E mandou a melodia. Eu aí fiz a letra:

Hoje tu voltas aqui, com o semblante a sorrir

Esperando que eu te receba e te dê muitos beijos de amor

Esquecendo, afinal, o que entre nós se passou

Foi você quem errou...

É um samba lindo mesmo. Clara acabou nem gravando, mas aí o Candeia decidiu gravar e mudou um pouquinho a letra: em vez de ser a mulher "sentida" falando, ele mudou para "perdida":

Tentarei te esquecer, perdida

Perdida, porque não honraste o homem...

Pra ele era isso:

- Se ficasse feminino eu não ia conseguir assinar.

O Candeia era tão machão que pegava as prostitutas, levava para a cadeia, botava todas nuas e jogava jato de água fria nelas. Saíam todas correndo quando ele chegava. Candeia era muito engajado também:

Negro, acorda, é hora de acordar...

... todas as raças já foram escravas também

Deixa de ser rei só na folia...

Esse era outro que se preocupava muito com a situação do sambista, procurava resistir. A Quilombo, escola de samba que ele fundou, com Nei Lopes e outros, era isso, para proteger o sambista, para proteger a cultura do negro. Candeia se engajava politicamente, e eu participava da escola também.

É isso, a vida do sambista é riquíssima. Alguém que nunca estudou também pode ensinar muita coisa... Nelson Cavaquinho, por exemplo, fez até o terceiro ano primário e olhe lá, porque ninguém podia completar nem o segundo grau, porque não tinha dinheiro, isso era para a pessoa da classe média, e todos nós vínhamos da classe baixa. E Deus deu esse privilégio, da inteligência, da sabedoria, ao sambista, e são missões. Eu digo que estou cumprindo uma missão, essa coisa que vem lá do alto, é uma dádiva, não só para mim, também para tantos outros que tiveram a dádiva de ser mensageiros do homem lá em cima, não é? Pra ensinar, ser professor.

$\mathrm{Eu}$ tenho amigos professores, médicos, que dizem que nós, que eu, sou professor da vida, eu sei mais do que ele, que estudou e fez faculdade nos Estados 
Unidos. Tem um professor lá no Fundão, o Doutor Roberto Medronho, um dos melhores professores de lá, que reúne os alunos e diz assim, do meu lado:

- Escuta aqui, esse aqui é o Seu Noca da Portela. Eu quero que vocês conheçam, porque é o meu professor. Eu sou professor de vocês, mas...

Aí os caras ficam sem saber:

- Professor de quê?

- De vida. Hoje eu ensino, mas muita coisa eu aprendi que ele me ensinou, e que não está nos livros, está nas coisas da vida, nas histórias. Eu passo esse ensinamento a vocês e vocês vão aproveitar pro futuro, viu?

Aí eu digo:

- Pô, Professor, não faça isso!

- Não, mas eu tô sendo sincero, eu não posso mentir pros meus alunos, eu aprendi muito contigo, poxa!

Ele é um dos caras mais importantes, está sempre na televisão, tem um programa na Rádio Globo, e é meu parceiro de música, do bloco Simpatia É Quase Amor. Ganhamos oito sambas no Simpatia, ganhamos seis no Barbas... É compositor, meu amigo, e através da música nós nos tornamos amigos, confidentes e parceiros, não só na música, mas fora da música. Todo ano eu faço um grande show pros alunos dele, lá no Fundão, e os alunos ficam, assim, felizes, dizendo:

- Pô, Seu Noca, o Doutor, o Professor Medronho tem um respeito, uma admiração pelo senhor, que o senhor nem imagina, e passa as coisas que ele aprendeu com o senhor pra gente...

Ele bota em matéria! Samba, por exemplo, ele bota em matéria, entendeu? Mostra lá um samba com o Noca:

- Olha só a poesia, a diferença desse samba pra esse, esse é do Noca. Aqui, olha a letra, vamos aprender, vamos saber o que é a poesia, o que é jogar com as palavras...

São tantos ensinamentos, não é? Ele tira proveito disso, coloca até tema de família, política. As coisas que acontecem com a gente aí, nessa caminhada, são coisas muito importantes de passar para as novas gerações, é por isso que eu quero lutar pra que o samba de quadra volte em todas as escolas de samba.

Quando eu fui Secretário de Cultura do Estado, eu trouxe de volta o samba de quadra, fiz um concurso em todas as escolas de samba, nas quadras, e dei prêmio, por isso quando vem um dinheiro desses, na época eu gastei $\mathrm{R} \$ 200$ e poucos mil, eu tirei como Lei de Incentivo, patrocínio, para premiar os cinco primeiros, e todo mundo ganhou. Teve escola que as pessoas vieram:

- Puxa, Seu Noca, podia ser só um dinheiro pro primeiro, mas o senhor deu pros cinco!

Lá na Mocidade, por exemplo, o compositor que ganhou era um senhor que há 30 anos não fazia, nunca mais tinha feito samba de quadra, e quando teve essa oportunidade fez um samba belíssimo. Aí ele falou:

- Puxa, Seu Noca, o senhor não sabe a alegria que o senhor está me dando, eu ficava pensando dia e noite, "puxa, nunca mais fizeram samba de quadra", e pra mim deu oportunidade de mostrar o meu talento...

É assim mesmo, o cara chorando, era época de final de ano, todo mundo com seu dinheirinho. 
- Seu Noca, e tem mais: sabe há quantos anos eu não faço o Natal pra minha família? Que não tem uma castanha na mesa? Uns oito anos, que eu não tenho dinheiro, e este ano vai ter um Natal na minha casa, pros meus netos, meus filhos.

O campeão na época levava R 5 mil.

- Seu Noca, puxa vida, eu vou endireitar meu barraquinho, vou fazer o Natal... Abaixo de Deus, só o senhor.

Eu digo:

- Não faça isso, rapaz!

- Não, precisou o senhor ir pra uma Secretaria pra a gente ter uma oportunidade de mostrar isso, Seu Noca. Esse disco aqui, que o senhor está me dando, aqui, vai ser a festa do meu Natal esse ano!

Coisas assim, de deixar a sua sensibilidade totalmente destroçada, você fazer a felicidade das pessoas, e assim foi em todas as escolas. E teve também a rapaziada nova que ganhou, na Viradouro, na Unidos da Tijuca, um dia eu estava chegando no aeroporto, o cara chegou:

- Seu Noca, eu tô indo lá pra Belo Horizonte!

Ele é músico, compositor de Rio das Ostras.

- Seu Noca, através daquele concurso que o senhor fez, o senhor abriu as portas, eu tô mostrando agora meu talento, tô viajando hoje!

- Mas, o que é isso? Você é de que escola, rapaz?

- Unidos da Tijuca, quem ganhou o samba lá fui eu!

- Poxa vida, você me desculpa, mas é tanta gente, poxa, meus parabéns!

- Não, eu é que tenho que dar os parabéns pro senhor, o senhor me deu uma oportunidade, tô indo agora pra Belo Horizonte! Vou lá, tô compondo, tô fazendo, me deu vontade de compor depois daquilo, ganhei, aí consegui mostrar minhas músicas, já gravei música à beça.

E eu digo:

- Meu Deus, que é isso, rapaz!

- É, Seu Noca, e só me descobriram porque eu ganhei o concurso.

Aí você fica pensando: por que as pessoas que estão no poder não prestigiam essas pessoas? Por que as autoridades não prestigiam a comunidade pra descobrir talentos, por que as escolas de samba, que tinham uma mina de ouro, que era a Ala dos Compositores, não têm a iniciativa de descobrir novos talentos? Estão se acabando os grandes compositores. Os caras estão indo pra um samba desses, fácil de ganhar dinheiro, esquecendo que a poesia é que tem que prevalecer. A poesia, a coisa mais bela do mundo é a poesia do samba de verdade, a poesia pura, sem mistura. $\mathrm{O}$ cara não tem necessidade de ser um intelectual para fazer rimas ricas, e isso tem a ver com os governantes, eles têm que manter essa chama acesa, das coisas poéticas que o nosso Rio de Janeiro, que o Brasil todo tem, você anda por esse país afora e escuta.

Eu fui umas vezes em Teresina, pensei que lá não tinha samba. Cheguei lá, em cada esquina tinha uma roda de samba, sambas maravilhosos, e o desfile de escolas de samba deles tem alegorias que muita escola do Grupo de Acesso daqui não tem. Lá em Teresina! E a cultura deles é o samba, e a maioria do país não sabe. Belém do Pará tem o carimbó, a Bahia tem o axé, Pernambuco tem o frevo, Maranhão tem o bumba-meu-boi, Manaus tem, todos têm o seu ritmo próprio, e Piauí não tem. 
Eu sou ídolo lá. É! A escola mais antiga, chamada Nossa Cara, tem 40 ou 50 anos, é a maior escola e nunca tinha ganhado um título, porque não tinha ala dos compositores, nem tinha compositor, tinha samba, mas samba-enredo não sabia fazer de jeito nenhum. Aí, fui fazer um show lá, inclusive foi com esse médico que eu falei, o Doutor Medronho, que diz que eu sou professor de vida dele. Chegando lá, os caras da escola de samba, o presidente da escola de samba, foram todos me receber no aeroporto, fizeram uma festa, aí o presidente da Nossa Cara me chama num canto:

- Poxa, Noca, nós fazemos tudo pra ganhar o Carnaval!

- Por que não ganharam ainda?

- Noca, falta o principal, que é o samba! Nossa ala dos compositores é formada só de intelectuais, eles fazem um samba com uma dificuldade danada! Botam palavras que o povo não sabe nem cantar! A língua fica presa!

E eu digo:

- É mesmo?

- Deveras, Noca! A maior alegoria é a nossa, a melhor alegoria, a melhor fantasia é a nossa, mas falta o principal, o samba.

É a escola da elite lá.

- E qual é o tema?

- Não, não é tema, não, é falar da Nossa Cara.

Eu digo:

- É merrmo, é? É só isso?

- É.

Aí eu fui pro hotel:

- Logo mais você vai lá que eu vou dar o samba pra você.

E fiz:

A Nossa Cara tem a cor da nossa raça

Que não disfarça tudo que esse povo é

Uma mistura de bravura e de bondade, apesar da tempestade

É um jequitibá de pé

O meu sentimento veste duas fantasias:

É Pierrô durante a noite

Arlequim durante o dia

A minha casa tem...

...tem arruda e tem magia

E o samba é companhia na alegria e na dor

Tem uma luz em frente ao quadro de Maria

Pois Jesus também foi feito do jeito que eu sou

Eu sou café, mandacaru e Raoni

Sou chimarrão, sou ouro em pó e bem-te-vi

Sou Pantanal e sou guerreiro desde 22 de abril

O criador me batizou: Brasil

Pronto, acabou o samba. Aí eles foram campeões. Eu estava com Monarco e Walter Alfaiate na Costa do Sauípe, que todo ano a gente faz show lá na competição de tênis, e daqui a pouco o celular fez esse barulho, esse toque de batucada que ele tem tcha-ca-tum-ba, e eu fui atender e o barulho de batuque continuou, aquela gritaria, e eu digo: 
- O quê que é? Alou? Quem tá falando?

- Ô Noca! É aqui de Teresina!

- Mas o quê que houve? Morreu quem?

- Noca, fomos campeões!

- Quê isso, rapaz!

- Sério, Noca! Agora só falta você, onde você está?

- Na Costa do Sauípe, fazendo um show logo mais, pro Guga!

- Ô Noca, semana que vem, dá pra vocês darem um pulinho aqui?

- Vocês que sabem...

- Não, me dá seu nome aí que eu vou comprar uma passagem, você vem pra cá festejar! Afinal de contas, 50 anos sem ganhar nada, é brincadeira, né?

Luiz Carlos da Vila, antes de morrer, gravou esse samba ${ }^{58}$. Luiz Carlos da Vila, conheceu? Foi cedo, esse foi. Acho que tinha 50, 51 anos.

${ }^{58}$ Cor da minha raça (Noca da Portela, Toninho Nascimento e Tranka) é a faixa 3 do CD Uma festa no samba, de Luiz Carlos da Vila, lançado em 1997. [faixa 25 do CD anexo] 
Zé Katimba em Niterói. Acervo pessoal da autora, dez. 2010.

"Sou vitorioso, graças a Deus, ao samba è̀ mulher"

Lugares de Zé Katimba:

1. Guarabira, PB

2. Praia do Poço (entre Tambaú e Cabedelo), PB

3. Largo da Batalha, Niterói, RJ

4. Morro da Formiga, Rio de Janeiro, $\mathrm{RJ}$

5. Morro de São Carlos

6. Morro do Adeus

7. Indicação aproximada no Centro da cidade: sem residência

8. Morro do Adeus (perto da quadra da Imperatriz Leopoldinense)

9. Cachambi

10. Niterói
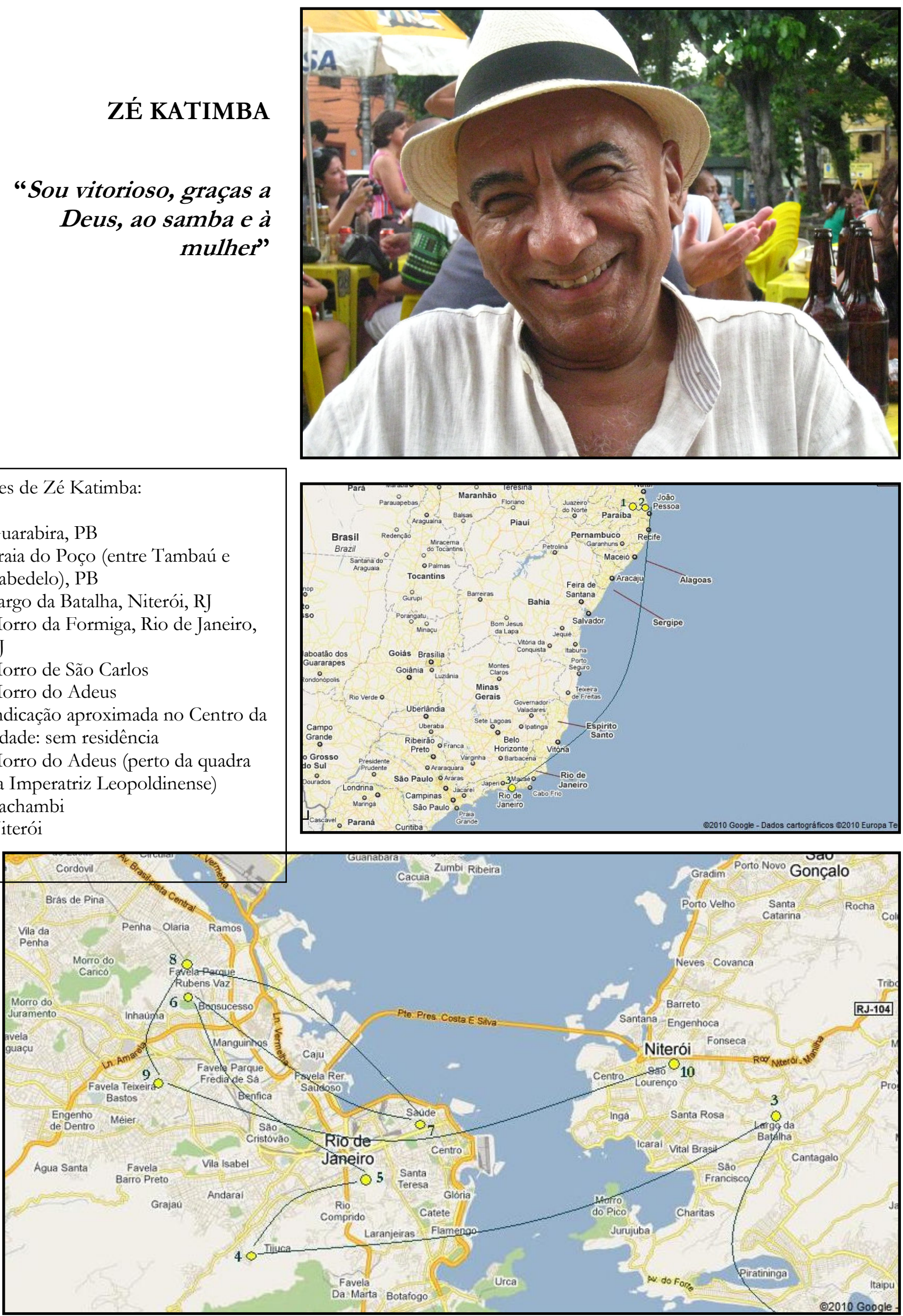
Na vida, você vale pelo que você tem ou pelo que você é. Eu sou. Não abro mão da minha dignidade, da minha verdade, daquilo que percebo nas pessoas. Eu acredito muito no ser humano, e quero ter vida longa pra continuar acreditando que logo, logo, vai começar uma mudança, vamos ter um mundo melhor, porque a juventude de hoje tem uma oportunidade muito grande. É apertar um botão e falar com o mundo, ter informações, estudar, às vezes a facilidade desvia um pouco, mas também faz parte do ser humano amadurecer. Tenho certeza de que as próximas gerações vão ter um mundo melhor.

Sou um cara de 76 anos com muita garra, disposição e vontade. Tenho certeza de que o tempo que eu durar, até o último instante, terei essa garra, essa vontade de passar informações e, principalmente, de aprender. Minha verdade pode não ser a de outras pessoas, mas cada um tendo informação pode agir à sua maneira. Quero aprender muito com as pessoas - crianças, velhos, adultos, até quem não teve oportunidade de freqüentar uma escola nem nada, às vezes com eles se aprende muito. Tenho essa vontade de realizar, de cantar, de compor, de amar, ser amado, respeitar, ser respeitado. Não abro mão do meu caráter. Acho que isso talvez seja um pouco de sabedoria de Deus.

Não me acho nem carioca nem paraibano, sou um brasileiro. É uma mistura: a Paraíba me deu a vida que tive com os meus pais na infância, o sofrimento, que foi uma base que me ensinou muito. Mesmo miudinho, eu aprendi muito. O Rio de Janeiro, a cidade grande, me deu também dificuldades, exatamente por não saber muita coisa, não ter informações. Hoje eu tenho condições de viver no Rio de Janeiro, em São Paulo, em qualquer estado do Brasil, porque a Paraíba e o Rio de Janeiro me deram essa moral.

O samba e a mulher têm me dado as maiores alegrias da minha vida: através do samba conheci pessoas que me deram filhos, e filhos que fazem samba, que são da música também. Sou uma pessoa muito feliz. Quando fico um pouco triste, vou fazer um samba. Começo a cantarolar e aí a tristeza vai embora, às vezes até aparece um amor. Não sei se eu suportaria as coisas todas que suportei - doença, câncer, disritmia, diabete - se eu trabalhasse em outro ramo. Talvez a atividade mais próxima do meu trabalho seja a Comunicação, também uma coisa divina. No mundo as coisas só mudam através da arte, da comunicação. Acho que só se eu trabalhasse na comunicação, ou até na educação, que infelizmente não é uma profissão reconhecida financeiramente, eu estaria realizado. E a mulher, que é um ser especial, maior, forte - eu sou fã da mulher; é a mulher que me deu tudo. Nas minhas letras não há nenhuma palavra de desafeto à mulher: tudo que eu possa fazer para exaltá-la ainda é menor que a minha dívida. É uma admiração imensa que sinto pela sabedoria, a sensibilidade, a luz da mulher, da recém-nascida à mais velha.

Gosto de lembrar tudo, até das coisas mais difíceis, das coisas mais sofridas. Assim eu vejo como eu consegui sair das situações de uma forma, que hoje poderia ser outra, mas transmito para os meus filhos, ou para as pessoas mais jovens, uma saída alternativa. Acho que as coisas boas são ótimas de lembrar, mas as coisas difíceis, como dividir a água com o gado, a seca, a fome, a desgraça, a escravidão dos senhores donos de terra no Norte e Nordeste, coisas pelas quais eu passei muito miúdo, desde que eu comecei a andar até os 10 anos, quando saí da minha terra, são 
importantes também. Eu vi muita coisa triste, e ainda existe muita coisa triste por lá: falta de emprego, falta de vergonha, falta de reconhecimento das pessoas, isso tudo é terrível. Mas acho que se eu consegui, junto com as pessoas do bem, como a Nely, minha amiga, a Simone, minha assessora de imprensa, o meu livro, a minha biografia, acho que isso vai ser uma contribuição para a sociedade paraibana, talvez do Brasil, sem pretensão. Precisamos recordar, mas ficar sempre atentos para que as experiências sirvam como lição e não como um sofrimento, criando outro problema que pode nos fazer perder um pouco da sensibilidade para as coisas boas que podem vir. Eu gosto de falar de tudo, eu gosto de ler tudo, de ver, e principalmente sentir.

Meu pai fazia literatura de cordel, então a minha herança musical com certeza é do meu pai. Era para eu fazer forró, mas tive contato com o samba. Descendo o morro para pegar água na lata, carregando a lata d'água na cabeça, feito a Maria - "lá vai Maria..." - a gente, a molecada, ia batucando na lata, cantando samba - esse foi meu primeiro contato e a partir daí nunca mais eu me afastei do samba, nem o samba de mim.

Só fiz um samba que fala da mãe, da mulher, de modo geral. Além da minha mãe, a professora é uma figura que me marcou e me ajudou muito. Era uma menina de 17 anos, que não era professora, não era formada, ensinava numa parede, num pedaço de madeira pendurado na fazenda, em Guarabira. Ela ensinava sem ter muita base, mas foi ali que eu aprendi, a partir dali é que eu comecei a ler, aos 9 anos, mesmo sem entender direito o que estava lendo. Nunca sentei num banco de escola, nunca tive escola nenhuma, nada, nunca tive um professor diante de mim. Essa menina foi muito importante, ela e minha mãe, que me deu a vida, que me gerou.

Minha mãe morreu cedo, morreu rápido, o câncer veio e a levou embora muito rápido. Eu vi a minha mãe... Apodrecer. Foi muito triste, não tinha nenhuma condição de tratar, não tinha o avanço de hoje, nem tinha condições financeiras. Minha mãe morreu no hospital em Laranjeiras, foi operada e não cicatrizou, porque era diabética. Eu era muito... Muito pequeno. Meu pai morreu logo depois da minha mãe, também de câncer. $\mathrm{O}$ do meu pai foi no pescoço, o da minha mãe foi no intestino e na coxa. Morreram muito rápido. Não tenho muita lembrança de datas, porque eu fiquei um pouco doente, um pouco maluco. Filho único, perdi as duas famílias, meu pai e minha mãe, e fiquei sozinho, sem nenhuma referência, sem nada. Não foi legal. Venci essa tristeza porque encontrei força, uma luz, que digo que é Deus. É uma luz que me protege, me guia. Consegui uma grana e fiz um tratamento, aí fiquei legal, mas esqueci tudo que eu tinha aprendido, não sabia mais escrever nem ler, e comecei a batalhar tudo de novo. Ainda era um menino.

$\mathrm{O}$ amor dos meus pais era imenso. Foi uma coisa muito linda que eu vi, esse amor, o dengo, o chamego, aquele carinho, aquela conquista de todos os dias, todas as horas. Meu pai foi um grande amante e minha mãe também, e se amaram muito.

Quando eles morreram, eu tinha amigos de rua, fui menino de rua. Depois eu fiquei descacetado, dormia no trem, vendia bala, engraxava sapato... Às vezes eu ia para a zona, fiz uma amizade com Pildes Pereira, dona do mangue da Avenida Presidente Vargas, que chegou a ser presidente da escola de samba Vila Isabel. Eu era querido por todos e era o único moleque que entrava lá. Acho que eu tinha uns 12 anos, e limpava os quartos para arrumar mais um dinheiro. Mas eu era muito miudinho - sou pequeno até hoje! Às vezes eu dormia lá e amanhecia com muita dor 
de cabeça, porque tinha muita creolina. As mulheres tinham relações e se lavavam com água e creolina, enxugavam e iam ter relações de novo. Aquele cheiro era forte, porque eram muitas, e muitos quartos.

Depois eu fui trabalhar com artefatos de couro, na Artefatos de Couro BeijaFlor, na Praça da República, número 46, que não existe mais. Aprendi lá com o Rodolfo, que era o dono, e depois trabalhei em todas as casas de artigo fino. Lancei em 1958 essa bolsa tira-colo, para a Seleção Brasileira - se tivesse registrado estaria trilionário. Trabalhei em todas as casas de artigo fino, na época em que se usava muito couro de crocodilo - eu cortava e emendava sem deixar marca. Foi um período muito legal, mas quando acabava o Natal, acabava o emprego, porque mandavam todo mundo embora. Depois veio o courvin: outros fabricantes compravam aquelas coisas que desenhávamos no artigo fino, desmanchavam e cortavam o courvin. Com isso, uma bolsa que custaria hoje $R \$ 200,00$ a $R$ \$ 500,00 eles vendiam por $R \$ 5,00$ a $R \$$ 10,00, do mesmo modelo. Aquilo desempregou muita gente, então eu desgostei e fui cuidar só da música. Eu já fazia música, mas larguei tudo e fui viver só da música, mesmo sem estar gravando. Levei muito tempo, uns dez anos, para gravar minha primeira música. Fui para São Paulo, corri atrás das coisas, ficava de um lado para o outro, até que um dia eu consegui.

Tem duas coisas que eu não lembro muito: de data e de telefone. Mas isso foi há muitos anos. Limpei caixa de gordura, fossa, fiz faxina, lavei carro, fiz o diabo. Teve uma época em que eu tinha vergonha de pedir dinheiro, então eu pedia ficha de telefone, dizendo que era para telefonar para arrumar um emprego, e aí todo mundo dava... Às vezes me davam um dinheiro também. Aí eu chegava na padaria e trocava a ficha de telefone por pão. Mas essa coisa da dificuldade dá uma base de vida, e você não pode desistir, não é? E nem achar que o caminho fácil é melhor, porque você não tem um final feliz - não vai ficar velho para contar a história.

Hoje, então, com a velocidade que a vida tem... Eu lembro que quando eu era garoto, acontecia alguma coisa nos Estados Unidos e levava seis meses, quando andava muito bem levava três, quatro meses, para chegar uma notícia aqui. Hoje a coisa está acontecendo, você vê na hora, tem uma reunião fechada e sai um cara ali, aperta um botão e joga na internet. A coisa ainda está sendo decidida e já está no mundo, todo mundo vendo, todo mundo sabendo daquilo. Então a gente precisa é de união, de acreditar mais no ser humano, porque toda essa coisa da evolução, da internet que é uma coisa fantástica, pode por outro lado ser uma coisa maligna. Mas tem o homem que programa, é o homem que faz, é o homem que decide. Eu acredito no ser humano.

Foi na Imperatriz Leopoldinense que eu gravei a minha primeira música, que era um samba de terreiro. Sou um dos fundadores da Imperatriz, em março de 1959, e ali as coisas foram acontecendo, os sambas foram surgindo, sambas de enredo, sambas de quadra. Um acontecimento marcante foi a novela Bandeira 2, já em 1972, escrita por Dias Gomes e que contava a minha vida, com Grande Otelo no papel de Zé Catimba (nessa época era com "c") e Jacira Silva no papel da minha mulher. Ela era a porta-bandeira da escola e Grande Otelo era o compositor principal. Depois as coisas foram acontecendo, as portas foram se abrindo e comecei a gravar mais, veio uma parceria com Martinho da Vila que dura até hoje - ele é o meu parceiro mais constante e sou o parceiro mais constante dele. Martinho foi fazendo projetos e 
lançando nos países que falam a língua portuguesa. Estive em Angola e foi um sucesso - quando eu começava a cantar, as pessoas cantavam junto, porque as músicas já eram tocadas, já eram conhecidas. E isso foi se alastrando pelo mundo, hoje eu tenho a minha obra espalhada no mundo todo, por volta de 800 músicas gravadas por muitas estrelas daqui, do Brasil, e no exterior também.

Lembro da Imperatriz com muita alegria, porque tudo que começa é difícil, mas você vai com todo o gás, cheio de tesão, coloca a sua energia numa coisa que começa pequena, para que ela cresça. Eu deixei a minha vida, a minha mocidade na Imperatriz, porque comecei puxando corda e fui passista, mestre-sala, presidente de ala, empurrador de carro, fiz alegoria, fiz samba... Depois teve a novela, ganhei alguns sambas-enredo, sucessos que deram campeonato à escola. Fui também vicepresidente numa chapa, depois o Luizinho Drummond, que era o presidente, se afastou e fiquei sendo presidente da escola. Então eu fui de fundador a presidente, passando por todas as funções, e isso também é está no livro, é uma história única não pelo mérito, mas pela sorte, o destino. Sou o único sambista que tem essa trajetória: da fundação de uma escola chegar até a presidência, e com o maior número de sambas-enredos ganhos, com toda uma carreira de sucesso, mestre-sala sempre com nota 10, passista reconhecido, presidente da ala de compositores. Sou um vitorioso, graças a Deus.

Continuo apaixonado, até hoje, mas a escola vai crescendo muito e vai mudando. Tudo na vida é assim, se você quer montar um negócio pra ter um lucro pequeno, o risco é pequeno. Se você monta uma empresa para ter muito lucro, você pode ter muito lucro, mas o risco também é muito grande. Com um grande amor, o risco também é muito grande. E a Imperatriz cresceu, ela também tinha muitos problemas e com algumas coisas eu não concordava. Como eu não poderia dar jeito e não queria me indispor com as pessoas, que ainda são meus amigos, eu me afastei um tempo, fiquei de 1999 até 2009 afastado da escola. Inclusive em 2008 eu desfilei na Portela, a convite do Monarco e da Velha Guarda da Portela, saí num carro na Portela, e no ano seguinte fui homenageado pela Imperatriz, na avenida, foi legal. Aí voltei, estou lá, mas a Imperatriz sempre foi um pedaço da minha vida, porque a minha história musical toda está na Imperatriz, a minha história de vida está toda ligada à Imperatriz. E o meu livro é isso, é minha vida, e conta os 50 anos de fundação da Imperatriz. Eu não posso desvincular, é como boca e batom, peixe e mar, não é? Não posso desvincular, porque uma coisa está ligada à outra.

No início, antes da fundação da Imperatriz, era uma coisa muito forte, as pessoas não podiam freqüentar outra escola, era barra-pesada. Mas depois não, já na fundação da Imperatriz, ser parceiro de alguém da Portela, o compositor da Mangueira fazer samba com o da Imperatriz, o do Império Serrano com o do Salgueiro, isso já tinha passado a ser uma coisa quase normal. Só na hora do desfile, cada um vai defendendo a sua bandeira; acabou o desfile, depois de divulgarem o resultado, começa tudo de novo, o que vale mesmo é o samba, a amizade. Até porque, sem união, nada feito. A gente precisa, cada vez mais, de muita união, de muita compreensão, ceder um pouco para tentar melhorar esse mundo.

Também ajudei com um movimento grande de valorização da Leopoldina. As pessoas se orgulhavam de morar em Madureira, da Portela pra cima, se orgulhavam de morar na Tijuca, em Copacabana, no Leblon, em Ipanema, mas na zona da 
Leopoldina nem pensar. As pessoas tinham vergonha, às vezes negavam que morassem lá. Mas com esse trabalho que eu fiz, político, social e musical, que foi se alastrando pelo mundo, eu fiz com que hoje o pessoal tenha um orgulho muito grande de morar no subúrbio da Leopoldina, porque ela ficou badalada, conhecida, a novela deu um empurrão muito grande, já que era gravada em Ramos. Outro dia eu encontrei com Ângela, mulher de Wilson Moreira, compositor de muito sucesso. Ela me abraçou emocionada, dizendo:

- Você é nosso orgulho, você fez com que o povo da Leopoldina se sentisse orgulhoso de morar na Leopoldina, através do teu trabalho, da tua contribuição.

E eu venho assim, fazendo a minha vida, não sou mais honesto nem mais sincero que ninguém, mas procuro fazer as coisas com verdade. Porque sem verdade não há tesão, não tem garra. É basicamente essa a minha vida.

Um dia eu falava com Martinho da Vila por telefone e ele disse:

- É, meu compadre, o nosso tempo passou.

Antigamente o samba não dava dinheiro, e era feito tudo na base do amor. Quando não tem dinheiro, a coisa fica um pouco mais... Controlada. Mas quando entra o dinheiro, o poder, descamba tudo. Para fazer um samba, ficou mais ou menos assim: dois compositores se juntam e fazem o samba. Aí entra um sujeito para pagar a carne e a bebida, para fazer festa nas comunidades, nos bares, para juntar uma torcida e levar para a quadra. Entra outro para pagar os prospectos e o aluguel dos ônibus; outro que paga o ingresso, a entrada do pessoal na quadra e a cerveja lá dentro. E todo mundo entra na composição. Então hoje é normal você pegar um samba e ter seis, oito compositores, porque aqueles que entram, entram pra aparecer. Quem tem grana, os donos de empresa, que têm uma situação boa, querem aparecer como compositores. Depois largam aquele compositor, quando não ganha mais, e se juntam com outras pessoas. As escolas de samba têm que prestar atenção nisso.

Agora o carnaval passa e uma semana depois você não lembra mais de nada. Do quê que você poderia lembrar? Do samba, porque a escola não é Grêmio Recreativo Escola de Alegoria, não é Grêmio Recreativo Escola de Carnavalesco, nem de Diretoria. É de samba. Grêmio Recreativo Escola de Samba. Então você canta samba de quando você nem era nascida, e você canta o samba inteiro, com alegria, é um samba bonito, porque ele foi feito dessa forma, com amor, com inspiração, com carinho, e foi escolhido pelo povo, pela comunidade. Agora não existe mais isso, exatamente porque o samba que tem mais torcida, mesmo aquele que não é nem legal, ganha. Você entra com um samba teu, você e mais um parceiro, mas você vai cantar e não tem um puxador oficial, você mesmo canta ou um amigo vai ajudar, e na quadra não tem ninguém cantando, a quadra está vazia. Aí chega um outro samba que é uma merda, um samba ruim para cacete, mas tem quinhentas, seiscentas pessoas cantando o samba de trás pra frente, de frente pra trás, numa alegria. Com isso você até fica iludido, achando que é aquilo, e não é. Eu poderia até fazer um samba, com essa idéia de mais uma vez dar a minha contribuição, pelo prestígio que tenho no mundo do samba, de a minha palavra ter eco, e reclamar, poder falar, sabendo até que vou perder, mas reclamar; mostrar, mais uma vez, dar a minha contribuição pra tentar mudar isso. Até faria, mas se fosse apenas para fazer mais um samba, não faria. Se fizesse, seria na Imperatriz. 
A Portela é a minha segunda escola. Ali eles me deram carinho, me deram apoio. Não que as outras não tenham dado, mas ali foi que me colocaram no carro, foi que me premiaram, me prestaram homenagem, enfim, tenho grandes recordações, fui tratado com muito carinho, com sinceridade. Minha primeira escola é a Imperatriz, e a minha segunda escola de paixão é a Portela. De portelense, compus com o João Nogueira, com o Monarco, não lembro se cheguei a fazer samba com outro portelense, mas samba-enredo não. Só na Imperatriz e, quando estava afastado, fiz um samba para a Viradouro. Estava me recuperando do câncer e me deu saudade de fazer um samba. Estava afastado da Imperatriz e, como a Viradouro é aqui perto... Moro em Icaraí e a Viradouro é pertinho, em 15 minutos estou na quadra, então foi uma questão de estar perto e matar saudade de fazer um sambaenredo, de escutar um samba.

No samba todo mundo me conhece, em todas as escolas, em qualquer lugar que eu chegue, me tratam bem... Sou considerado. Considero todo mundo também.

Vou agora gravar um CD de que Martinho da Vila vai participar cantando e produzindo, só com músicas minhas e dele, pelo selo do Candongueiro (casa de samba de Niterói), que está começando. Vamos chamar Beth Carvalho e Paulinho da Viola para fazer participações e o disco deve ser gravado em um show de três dias, de sexta a domingo, depois voltaremos para o estúdio, para os ajustes finais. Acho que vai ser um grande acontecimento. Mais uma vez, o samba me coloca numa posição maravilhosa, vou dando minha contribuição ao Candongueiro, que é uma casa de resistência do samba, no Brasil e no mundo. Estou fazendo parte dessa história, inclusive dediquei um capítulo do meu livro ao Candongueiro.

A parceria com o Martinho começou há muitos anos, quando fui assistir a um show dele, que tinha estado doente e ao sair do hospital fez esse show no teatro João Caetano. A gente já se conhecia de jornal, de revista, mas não tínhamos intimidade. A essa altura eu já tinha ganhado dinheiro e jogado o dinheiro fora, por não saber aplicar. Eu estava sem grana e - ironia do destino - cheguei no show e a Russa, exmulher de Martinho, me pediu pra ajudá-lo. Naquela época ele era o maior vendedor de disco do país. Eu fui para a casa da Russa no dia seguinte, feliz da vida, porque era fã do Martinho e nunca tinha gravado nada com ele.

Primeiro, ficamos quinze dias em silêncio absoluto, nenhum dos dois falava nada. Depois de duas semanas começamos a trocar palavras e acabamos fazendo um samba, e estamos até hoje. Há bem pouco tempo, em abril, fizemos dois sambas: um em homenagem a Dona Ivone Lara e outro que Simone encomendou para seu próximo disco. Agora vamos fazer esse trabalho, do CD, e tem também um DVD a ser gravado no Morro da Urca, com as estrelas todas que gravam Zé Katimba: Simone, Alcione, Beth Carvalho, Fundo de Quintal, Diogo Nogueira, meu filho Inácio Rios, Almir Guineto, Lecy Brandão, Jair Rodrigues, Elza Soares, Martinho da Vila, Zeca Pagodinho, além dos sambas-enredo pelos puxadores, mestre-sala, portabandeira. Isso e o lançamento do livro formam um grande projeto, que vai ser muito legal e deve acontecer, porque tem uma empresa interessada em financiar.

Hoje eu estou aí com o livro na rua, um livro bonito, escrito pelo Fernando Paulino, com um texto maravilhoso e um acabamento que, dentre os de samba, acho que é dos mais bem apresentados. E é uma história boa, uma história única, porque eu, por destino, por sorte, fui construindo uma carreira, uma história interessante. 
Fui o primeiro compositor de samba a ter um samba em novela, o primeiro a diminuir o tamanho do samba, que tinha 60 a 65 e eu diminuí para 18 a 20 linhas (coisa que depois passou a ser o padrão), fui o primeiro a gravar com uma ala de tamborins dentro do estúdio, enfim.

Tenho um trabalho que é reconhecido no mundo. Isso já é uma coisa boa, pra mim. E eu acho que o meu livro, essa minha biografia, vai dar um suporte maior, vai divulgar esse trabalho, dar a minha contribuição para os próximos sambistas. Não que vá dar dinheiro, pode até dar algum dinheiro, mas não é assim, coisa de fortuna. Vai dar mais prestígio que outra coisa, porque nós vamos lançar nos países que falam a língua portuguesa, o Martinho já faz esse projeto de todo ano lançar disco na Comunidade dos Países de Língua Portuguesa, então a biografia vai me dar um prestígio maior, as pessoas vão conhecer, saber mais da minha vida. Pode abrir outras portas, pode surgir um filme desse livro, pode surgir um documentário, um curta, pode sair um especial para uma novela, enfim... Vamos deixar por conta de Deus.

Se Deus quiser, em breve voltarei para Guarabira, minha terra, para ser homenageado. Quando saí de lá, aos 10 anos, eram umas poucas casinhas, barracos, e hoje já é uma cidade grande, com 60 a 70 mil habitantes. O Governo da Paraíba quer me homenagear, então estamos negociando para colocar o livro, minha biografia, no Ensino Médio. Acho que vai ser uma contribuição para que as pessoas batalhem, nunca desistam, porque as coisas são difíceis, mas valem a pena.

Nunca faço uma música pensando que ela vai ser sucesso, ou que vai me dar dinheiro. Eu basicamente faço as canções pensando numa coisa legal, numa mulher, num amor. Eu vou mais para a sensualidade da mulher, para a grandeza da mulher. Não tem como, enquanto existir um coração batendo num peito, vai existir esse retorno, é certo. Vai sempre bater na cabeça de alguém, porque tanto faz o sem informação nenhuma, sem escola, sem nada, como o intelectual, bem informado, ele tem o mesmo sentimento, não é? Todo mundo tem o mesmo sentimento. $O$ amor, quando atinge, o sujeito fica burro. Quer dizer, ele fica mais sensível, mais aberto e se mostra melhor. Às vezes ele fica naquele pedestal, mas aí quando está amando, se mostra por inteiro. É essa coisa do amor, a força, o poder da mulher.

Eu queria viver de música, eu queria ouvir a minha música tocando no rádio, eu não tinha nem noção se dava muito dinheiro, se dava pouco dinheiro: meu desejo maior era ouvir alguém cantando a minha música, tocando no rádio. É assim até hoje. Se me dá dinheiro ou não... Normalmente dá, não é? Quando a música é gravada por uma estrela, a divisão do dinheiro da venda é igual, porque é dividido por faixa, mas a música que está tocando ganha 10, 12 vezes mais, porque ganha como execução, você tem condições de ser homenageado, de cantar, de se apresentar, enfim... Tem um retorno financeiro maior. Pela quantidade de obra, e pela quantidade de obra no mundo, pelo reconhecimento da obra, eu deveria ser milionário, mas está dando para viver... Sobreviver. Mas eu não estou ligado nisso, estou ligado em fazer uma música de que eu goste. Como tem dado certo, eu fico feliz... Você quer ouvir a mais recente, que eu fiz com Martinho, para encerrar?

Eu já tinha a música. E aí eu fiz uma primeira, e depois... Eu nem escrevo nem sei tocar, nem conheço, não sei uma nota musical. Às vezes eu gravo a melodia; às vezes ela fica gravada na cabeça. Quando ela vem e fica, tenho quase certeza que ela 
é sucesso. Essa letra é mais uma coisa que a gente diz, não é? A maioria das pessoas, dos apaixonados ou não, às vezes numa transa dizem:

- Minha puta...

Quer dizer, tem o mangue, tem a flor do mangue, tem o lodo, o engodo.

A Simone encomendou para o próximo CD e DVD, e meu filho Inácio vai tocar ${ }^{59}$. Em primeira mão pra você:

Eu quero você na minha veia

Porque você é o meu sangue

Desejo ser seu sem engodo,

Ser o vegetal do seu lodo

E você, a flor do meu mangue

Você é uma lua cheia

Que lá no meu céu se descamba

Porém não é só minha musa

Na minha cabeça cafuza

Você é o meu próprio samba

Riqueza da minha rima

$O$ verso da poesia

Gostosa gastronomia

A minha ideologia

E de Olorum, obra-prima

Meu Deus como eu quero você

Eu quero você na minha veia

Porque você é o meu sangue

Desejo ser seu sem engodo,

Ser o vegetal do seu lodo

Você, a flor do meu mangue

Riqueza da minha rima

$O$ verso da poesia

Gostosa gastronomia

A minha ideologia

E de Olorum, obra-prima

Meu Deus como eu quero você...

\footnotetext{
${ }^{59}$ Na minha veia (Zé Katimba e Martinho da Vila) é a faixa 4 do CD Na veia, lançado por Simone em 2009. [faixa 27 do CD anexo]
} 


\title{
CONSIDERAÇÕES FINAIS
}

\author{
Tempo me disse que só com tempo \\ A gente chega lá. \\ Zé Luiz do Império Serrano e Nelson Rufino, Tempo ê.
}

Passados três anos desde o início deste trabalho, o balanço é, sem dúvida, positivo. De inquietações genéricas, desenhou-se um universo de pessoas e sambas muito reais. Cada pessoa se referindo a muitas outras, quase sempre parentes por sangue ou afinidade; cada samba ecoando uma série que tende ao infinito de outros que vieram antes ou depois. Parece que agora, que é imperativo chegar ao fim, seria o momento ideal para começar a pesquisa, como se tivesse sido possível olhar pela fresta de uma grande porta, que pede para ser aberta.

Retomando o problema colocado no início, recorro uma última vez a José Sávio Leopoldi, que descreve e sintetiza a situação contraditória vivida pelas escolas de samba, quando ela ainda recentemente se esboçava:

...a própria agremiação vivencia uma contradição básica na tentativa de
conciliar dois aspectos que acompanham a definição de seus elementos
característicos: de um lado, valorizando os atributos e os agentes do mundo
do samba, ela procura ressaltar a sua autenticidade (no sentido de ser
reconhecida como expressão da "cultura popular brasileira"), aspecto que se
encontra na base das formulações fantasiosas e que, talvez por isso mesmo,
constitui a garantia da sua promoção pelas agências interessadas em destacar
nela a "pureza" das manifestações populares; de outro lado, em vista das
condições atuais da apresentação pública, que a impeliu ao crescimento
desmesurado e à plena aceitação dos segmentos alheios ao seu contexto - em
cuja influência identifica sintomas de uma "efetiva" ascensão social - a
Escola de Samba submete-se a transformações que tendem a distanciá-la de
sua imagem original (LEOPOLDI, 1978, pp. 132-133).

Se parece claro que as escolas de samba vivem essa contradição desde sua gestação, também é certo que suas proporções passaram a ser outras a partir da gravação dos primeiros discos de samba-enredo no final da década de 1960, processo que passou a mais diretamente "mexer no samba", como disse Wilson das Neves citando o Argumento de Paulinho da Viola.

Ao mesmo tempo em que as mudanças na estrutura das escolas de samba se fazem sentir dentro e fora da avenida, o caso da velha guarda excluída do desfile em 2005 demonstra que há limites para as concessões que os setores identificados como tradicionais da escola podem suportar. A grande repercussão desse episódio e as imediatas medidas de reparação evidenciam a gravidade atribuída àquela situação atípica, que decorre do objetivo de vencer o carnaval. Nesse caso, a observância aos quesitos de julgamento externo da escola significou, 
paradoxalmente, na avenida, a exclusão simbólica da memória, da história da escola, do que ela teria, portanto, de mais essencial. Pelo que se observa em algumas das narrativas, é importante que a escola vença, mas o mais importante é respeitar a tradição.

Uma hipótese que não foi possível ainda explorar foi a de que as Velhas Guardas musicais, esses repositórios de ensinamentos e sambas ligados às raízes das escolas, teriam surgido justamente no momento em que a contradição das escolas se exacerbou, coincidindo também com a crise das escolas consideradas "hegemônicas" até a década de 1970.

O olhar da velha guarda, voltado para dentro e para o passado da agremiação, poderia ser complementar ao olhar voltado para fora e para o futuro, característico da escola que se organiza em torno do defile de carnaval, não devendo com isso as duas instâncias serem vistas como polarizadas ou opostas apenas. Há negociações permanentes e, inclusive, a indicação de caminhos alternativos. Feijoadas e sambas de quadra foram apontados por sambistas como hábitos que permitiriam resgatar a atmosfera na qual um dia se formaram as escolas de samba do Rio de Janeiro: a do respeito aos valores coletivos e da convivência entre jovens e velhos, com ascendência destes sobre os primeiros.

Outros dos espaços por onde as Velhas Guardas musicais têm novas possibilidades de permanência para seus repertórios, além dos registros gravados, são as rodas de samba, blocos de rua e apresentações musicais de artistas que buscam nas Velhas Guardas uma referência, uma inspiração.

Mais que grupos da escola, ou de pessoas do samba, as velhas guardas são o samba em pessoa. 


\section{REFERÊNCIAS}

- Bibliográficas

ALENCAR, Edigar de. Nosso Sinhô do Samba. Rio de Janeiro, Ed. Civilização Brasileira, 1968. Editora, 1980.

O Carnaval carioca através da música. Rio de Janeiro/Brasília, Francisco Alves

ALMEIDA, Renato. História da música brasileira. F. Briguet \& Comp. Ed., 1926.

ALVITO, Marcos. As Cores de Acari. Rio de Janeiro, Fundação Getúlio Vargas, 2001.

CADERNO DE TEXTOS DO CURSO Samba, Festa e Cultura Popular, Rio de Janeiro, $2002-2^{\circ}$ semestre.

ANDERSON, Benedict. Comunidades imaginadas: Reflexões sobre a origem e a difusão do nacionalismo (tradução de Denise Bottman). São Paulo, Companhia das Letras, 2007.

ANDRADE, Mário. Ensaios da música brasileira. São Paulo, Livraria Martins Ed., 1962.

ARAÚJO, Paulo Cesar de. Eu não sou cachorro não: música popular cafona e ditadura militar. Rio de Janeiro, Record, 2002.

ARRUDA, Maria A. do Nascimento. Mitologia da mineiridade: o imaginário mineiro na vida política e cultural do Brasil. São Paulo, Brasiliense, 1999 (1990), $1^{\text {a }}$ reimpressão.

AUGRAS, Monique. O Brasil do samba-enredo. Rio de Janeiro, Editora Fundação Getúlio Vargas, 1998.

BLOCH, Marc. Apologia da história, ou, O oficio de historiador (tradução de André Telles). Rio de Janeiro, Jorge Zahar Ed., 2001.

BOSI, Ecléa. Memória e sociedade - lembranças de velhos. São Paulo, Cia. das Letras, 1994.

BURKE, Peter (org). A escrita da história: novas perspectivas (tradução de Magda Lopes). Rio de Janeiro, Record, 1992.

CABRAL, Sérgio. As escolas de samba do Rio de Janeiro: o quê, quem, como, quando e por quê. Rio de Janeiro, Fontana, 1974.

. As escolas de samba do Rio de Janeiro. Rio de Janeiro, Lumiar Editora, 1996.

CALDEIRA, Jorge. A construção do samba. São Paulo, Edições Mameluco, 2007.

CANDEIA FILHO, Antonio \& ARAÚJO, Isnard. Escola de samba: árvore que esqueceu a rair. Rio de Janeiro, Lidador/SEEC, 1978. 
CANETTI, Elias. Massa e Poder (tradução de Sérgio Tellarolli). São Paulo, Cia. das Letras,1995.

CARVALHO, José Murilo de. A formação das almas: o imaginário da República no Brasil. São Paulo, Companhia das Letras, 1990.

CASTRO, Maurício Barros de. Zicartola: política e samba na casa de Cartola e Dona Zica. Rio de Janeiro, Relume Dumará, Prefeitura, 2004.

CAVALCANTI, Maria Laura Viveiros de Castro. Carnaval carioca: dos bastidores ao desfile. Rio de Janeiro, Ed. UFRJ, 2008 [1994].

CERTEAU, Michel de. A escrita da história. Rio de Janeiro, Forense Universitária, 1982

CUNHA, Maria Clementina Pereira (org.). Carnavais e outras f(r)estas: ensaios de história social da cultura. Campinas, Editora da Unicamp, CECULT, 2002.

DICIONÁRIO Houaiss da língua portuguesa. Rio de Janeiro, Objetiva, 2001.

DICTIONNAIRE Le Robert pour tous. Paris, 1994.

ELIAS, Norbert. Mozart, sociologia de um gênio (tradução de Sergio Goes de Paula). Rio de Janeiro, Jorge Zahar Ed., 1995.

FAOUR, Rodrigo. História sexual da MPB: a evolução do amor e do sexo na canção brasileira. Rio de Janeiro, Record, 2006.

FAUSTO, Boris. O pensamento nacionalista autoritário (1920-1940). Rio de Janeiro, Jorge Zahar Ed., 2001.

FENERICK, José Adriano. Nem do morro nem da cidade: as transformações do samba e a indústria cultural. São Paulo, Annablume/Fapesp, 2005.

FERREIRA, Felipe. O Livro de ouro do carnaval brasileiro. Rio de Janeiro, Ediouro, 2004.

GALVÃO, Walnice Nogueira. Ao som do samba: uma leitura do carnaval carioca. São Paulo, Editora Fundação Perseu Abramo, 2009.

GARCÍA CANCLINI, Nestor. Culturas Hibridas: estratégias para entrar e sair da modernidade (tradução de Heloísa Pezza Cintrão e Ana Regina Lessa; tradução da introdução de Gênese Andrade). São Paullo, Editora da Universidade de São Paulo, 2008 (1997), $4^{a}$ ed.

GINZBURG,Carlo. Ohos de madeira: nove reflexões sobre a distância (tradução de Eduardo Brandão). São Paulo, Cia. das Letras, 2001.

GOLDWASSER, Maria Julia. O Palácio do samba: estudo antropológico da Escola de Samba Estação Primeira de Mangueira. Rio de Janeiro, Zahar Editores, 1975.

GONZÁLEZ, Juan Pablo \& ROLLE, C. "Escuchando el pasado: hacia una historia social de la música popular". In Revista de História, USP, n 157, 2007, pp. 31-54.

GUIMARÃES, Francisco. Na roda do Samba. Mec/Funarte, 1978. 
HOBSBAWM, Eric. A Era das Revoluções (1789-1848) (tradução de Maria Tereza Lopes Teixeira e Marcos Penchel). Rio de Janeiro, Paz e Terra, 1977.

HOBSBAWM, Eric \& RANGER, Terence (orgs). A Invenção das Tradições (tradução de Celina Cardim Cavalcante). Rio de Janeiro, Paz e Terra, 1984.

HOLANDA, Sérgio Buarque. Raízes do Brasil. Rio de Janeiro, José Olympio Editora, 1982. (org). História Geral da Civilizaçãa Brasileira. São Paulo, Difel, 1985.

JOHNSON, Paul. Napoleão. Rio de Janeiro, Objetiva, 2002.

LE GOFF, Jacques. História e memória. Campinas, Editora da Unicamp, 2003.

LEOPOLDI, José Sávio. Escolas de samba: ritual e sociedade. Petrópolis, Vozes, 1978.

LEVI, Giovanni. "Usos da biografia”. In FERREIRA, Marieta de Moraes \& AMADO, Janaína. Usos e abusos da história oral. Rio de Janeiro, Editora Fundação Getúlio Vargas, 2001.

LEVILLAIN, Philippe. “Os protagonistas: da biografia”. In RÉMOND, René (org.). Por uma história política (tradução de Dora Rocha). Rio de Janeiro, Editora Fundação Getúlio Vargas, $2^{\mathrm{a}}$ ed, pp. 141-184.

LOPES, Nei. O samba na realidade: a utopia da ascensão social do sambista. Rio de Janeiro, Codecri, 1981.

. O negro no Rio de Janeiro e sua tradição musical: partido-alto, jongo, chula e outras cantorias. Rio de Janeiro, Pallas, 1992. Palavra, 2003.

Sambeabá: o samba que não se aprende na escola. Rio de Janeiro, Folha Seca/Casa da Partido-alto: samba de bamba. Rio de Janeiro, Pallas, 2005.

MARIANO, Agnes. A Invenção da baianidade. São Paulo, Annablume, 2009.

MATOS, Claudia Neiva de (org). Ao encontro da palavra cantada: poesia, música e voz. Rio de Janeiro, 7 letras, 2001.

Terra, 1982.

Acertei no milhar: samba e malandragem na época de Getúlio. Rio de Janeiro, Paz e

MATTA, Roberto da. Carnavais, malandros e heróis: para uma sociologia do dilema brasileiro. Rio de Janeiro, Jorge Zahar Ed., 1997 [1979].

Universo do carnaval: reflexões e imagens. Rio de Janeiro, Pinakotheke, 1981.

MATTOS, Rômulo. A aldeia do mal: o morro da favela e a construção social das favelas durante a Primeira República. Dissertação de Mestrado em História Social. Niterói, Universidade Federal Fluminense, 2004. 
MEIHY, José Carlos Sebe Bom. Carnaval, Carnavais. São Paulo, Ática, 1986. - A colônia brasilianista: história oral de vida. São Paulo, Nova Stella, 1990. . Manual de história oral. 5 ed. São Paulo, Loyola, 2005.

"Notas sobre a moderna 'tradição oral': tropicalização do deserto e o fabulário árabe no imaginário brasileiro". Revista Brasileira de História Oral, nº1, v. 10.

2008. “'Ser árabe na cultura brasileira: construção de identidade”. Tiraz, n5, São Paulo,

MEIHY, José Carlos Sebe Bom \& HOLANDA, Fabíola. História oral: como fazer, como pensar. São Paulo, Contexto, 2007.

MERRIAM-WEBSTER'S collegiate dictionary. 10th ed. Massachusetts, 1996.

MORAES, José Geraldo Vinci. "Modulações e novos ritmos na oficina da História”. In Revista Galega de Cooperación Científica, España, n 11, 2005, pp. 49-56.

"História e historiadores da música popular no Brasil". In Latin American Music Review, vol. 28, n², 2007, pp. 271-299.

MUSSA, Alberto \& SIMAS, Luiz Antonio. Samba de enredo: bistória e arte. Rio de Janeiro, Civilização Brasileira, 2010.

NAPOLITANO, Marcos. Seguindo a canção: engajamento político e indústria cultural na MPB (1959/1969). São Paulo, Anna Blume/FAPESP, 2001.

. História \& Música: história cultural da música popular. Belo Horizonte, Autêntica, 2002.

- A sincope das idéias: a questão da tradição na música popular brasileira. São Paulo, Fundação Perseu Abramo, 2007.

NEVES, Wilson das. "De pajé para curumim" (entrevista concedida a Curumim). In Revista Continuum (Itaú Cultural), nº 24, jan./fev. 2010.

NORONHA, Luiz. Malandros: notícias de um submundo distante. Rio de Janeiro, Relume Dumará, Prefeitura, 2003.

ONG, Walter J. Orality and Literacy: the technologizing of the word. New Accents. Nova York, Routledge, 2006 (1982).

ORLANDI, Eni Puccinelli. As formas do silêncio: no movimento dos sentidos. Campinas, Editora da UNICAMP, 1997, $4^{\mathrm{a}}$ ed.

PATAI, Daphne. História oral, feminismo e politica (tradução de Fernando Luiz Cássio e Ricardo Santhiago). São Paulo, Letra e Voz, 2010. 
PAULINO, Fernando. Zé Katimba - que grande destino reservaram para você!. Niterói - RJ, Panorama, 2009.

PINHEIRO, Paulo César. Histórias das minhas canções. São Paulo, Leya, 2010.

POLLAK, Michael. "Memória, esquecimento, silêncio". Estudos Históricos, Rio de Janeiro, v. 2, n. 3, 1999.

PORTELLI, Alessandro. "Sonhos ucrônicos: memórias e possíveis mundos dos trabalhadores". Projeto de História, São Paulo, PUC, n. 10, dez. 1993. 1997.

. "O que faz a história oral diferente". Projeto de História, São Paulo, PUC, n. 14, fev.

RIDENTI, Marcelo. Classes sociais e representação. São Paulo, Cortez Editora, 1994.

RODRIGUEZ, Helio Suêvo. A Formação das Estradas de Ferro no Rio de Janeiro - o resgate da sua memória. Rio de Janeiro, Sociedade de Pesquisa para Memória do Trem, 2004

SANDRONI, Carlos. Feitiço Decente: transformações do samba no Rio de Janeiro (1917-1933). Rio de Janeiro, J. Zahar / Ed. UFRJ, 2001.

"Adeus à MPB". In: CAVALCANTE, Berenice et al. (orgs.) Decantando a República: inventário histórico e político da canção popular moderna brasileira. Rio de Janeiro, Nova Fronteira, 2004.

SANTHIAGO, Ricardo. Cantora negra na música "dos brancos"? História oral de vida artística. Dissertação de mestrado, DH/FFLCH-USP, 2009. . Solistas Dissonantes: História (oral) de cantoras negras. São Paulo, Letra e Voz, 2009.

SARLO, Beatriz. Tempo Passado: cultura da memória e guinada subjetiva (tradução de Rosa Freire d’Aguiar). São Paulo, Cia. das Letras, 2007.

SEVCENKO, Nicolau. Orfeu extático na metrópole. São Paulo, Cia. Das Letras, 1998.

SILVA, Eloíza Maria Neves. Histórias de vidas de mulheres negras: estudo elaborado a partir das escolas de samba paulistanas. Dissertação de Mestrado em História Social. São Paulo, FFLCH/USP, 2002.

SILVA, Marília Trindade Barboza da \& MACIEL, Lygia dos Santos. Paulo da Portela: traço de união entre duas culturas. Rio de Janeiro, Funarte, 1979.

SILVA, Marília Trindade Barboza da \& OLIVEIRA FILHO, Arthur Loureiro de. Pixinguinha: filho de Ogum Bexiguento. Rio de Janeiro, Gryphus, 1998.

SLIM, Hugo \& THOMPSON, Paul. Listening for a change: oral testimony and community development. Philadelphia: New Society Publishers, 1995.

SODRÉ, Muniz. Samba, o dono do corpo. Rio de Janeiro, Mauad, 1998. 
SOIHET, Rachel. A subversão pelo riso: estudos sobre o carnaval carioca da Belle Époque ao tempo de Vargas. Rio de Janeiro, Editora Fundação Getúlio Vargas, 1998.

TATIT, Luiz. O século da canção. São Paulo: Ed. Ateliê, 2004.

TINHORÃO, José Ramos. Música Popular: um tema em debate. Rio de Janeiro, JCM Editores, 1969.

Editores, 1969.

- O samba agora vai: a farsa da música brasileira no exterior. Rio de Janeiro, JCM . Os sons dos negros no Brasil: cantos, danças, folguedos: origens. São Paulo, Art Editora,

1988.

. História social da música popular brasileira. São Paulo, Editora 34, 1998.

. Os sons que vêm das ruas. São Paulo, Editora 34, 2005.

TODOROV, Tzvetan. Les abus de la mémoire. Paris, Arléa, 2004.

TOTA, Antonio Pedro. Samba da legitimidade. Dissertação de mestrado, DH/FFLCH-USP, 1980.

VALENÇA, Rachel Teixeira \& VALENÇA, Suetônio Soares. Serra, Serrinha, Serrano: o império do samba. Rio de Janeiro, Livraria José Olympio Editora, 1981.

VASCONCELOS, Ary. Panorama da música popular brasileira, vol. I. São Paulo, Ed. Martins, 1964.

VARGENS, João Baptista M. \& MONTE, Carlos. A Velha Guarda da Portela. Rio de Janeiro, Manati, 2001.

VELHO, Gilberto. Projeto e metamorphose: a antropologia das sociedades complexas. Rio de Janeiro, Jorge Zahar Ed., 1994.

VIANNA, Luiz Fernando. Geografia carioca do samba. Rio de Janeiro, Casa da Palavra, 2004.

VIANNA, Hermano. O mistério do samba. Rio de Janeiro, Jorge Zahar Editor, Editora UFRJ, 1995.

WISNIK, José Miguel. Machado Maxixe. São Paulo, Publifolha, 2008.

ZALUAR, Alba \& ALVITO, Marcos (orgs.). Um século de favela. Rio de Janeiro, Editora Fundação Getulio Vargas, 1998.

\section{- Em outros suportes}

\section{Álbuns (em vinil ou CD*)}

PORTELA. A Vitoriosa Escola de Samba Portela. Sinter, 1957.

JAMELÃO. Escolas de Samba. Continental, 1957.

PORTELA E IMPÉRIO SERRANO. Samba no chão. 1962.

PORTELA. Grandes Sucessos E. S. Portela. Copacabana, 1963.

IMPÉRIO SERRANO. Samba, oração do morro. Copacabana, 1963.

MENSAGEIROS DO SAMBA DA PORTELA. A vez do morro. Polydor, 1966. 
VELHA GUARDA DA PORTELA. Portela, passado de glória. RGE, 1970.

PORTELA. Minha Portela querida. Rio de Janeiro, Odeon, 1972.

MONARCO. Monarco. WEA, 1976.

ALVAIADE, ALVARENGA, DUDUCA DO SALGUEIRO, ISMAEL SILVA, MANO DÉCIO DA VIOLA, NELSON CAVAQUINHO, NOEL ROSA DE OLIVEIRA, WALTER ROSA. Encontro com a Velha-guarda. Philips, 1976.

CANDEIA. Axé: gente amiga do samba. WEA, 1978.

MONARCO. Terreiro. Eldorado, 1980.

VELHA GUARDA DA PORTELA. Grandes Sambistas: Velha Guarda da Portela. Kuarup, 1986.

VELHA GUARDA DA PORTELA. Homenagem a Paulo da Portela. Nikita Music, 1988.

VELHA GUARDA DA MANGUEIRA. Mangueira chegou. Nikita Music, 1989.

ZECA PAGODINHO. Samba pras moças. Polydor, 1995.

NEI LOPES. Zumbi - 300 anos canto Banto. Saci, 1996.

WILSON DAS NEVES. O som sagrado de Wilson das Neves. CID, 1996.

LUIZ CARLOS DA VILA. Uma festa no samba. Velas, 1997.

VELHA GUARDA DA MANGUEIRA. Velha-Guarda da Mangueira e convidados. Nikita Music, 1999.

GUILHERME DE BRITO, MONARCO, NELSON SARGENTO, WILSON MOREIRA. Velhas companheiras: Mangueira e Portela. Nikita Music, 2000.

VELHA GUARDA DO SALGUEIRO. Velha-guarda do Salgueiro. Sum Records, 2000.

VELHA GUARDA DA PORTELA. Tudo azul. EMI, 2000.

DICRÓ. Dicró no Piscinão. Universal Music, 2002.

TIA SURICA. Surica. Rob Digital, 2004.

VELHA GUARDA DA VILA ISABEL. Sou Velha-guarda, muito prazer. MZA Music, 2005.

ZÉ LUIZ DO IMPÉRIO SERRANO. Zé Luir Selo Candongueiro, 2005.

VELHA GUARDA DO IMPÉRIO SERRANO. Um show de Velha-guarda. Biscoito Fino, 2006.

TANTINHO DA MANGUEIRA. Tantinho, memória em verde e rosa. Independente, 2006.

ARLINDO CRUZ. Sambista perfeito. Deckdisc, 2007.

TANTINHO DA MANGUEIRA. Tantinho canta Padeirinho da Mangueira. Independente, 2009.

WILSON DAS NEVES. Pra gente fazer mais um samba. MPB Universal, 2010.

SIMONE. Na veia. Biscoito Fino, 2009.

* quase todos disponiveis também em wnw.sambaderaiz.net.

\section{Páginas da internet}

www.army.mil/info/organization/unitsandcommands/commandstructure/theoldguard/. Sobre a Velha Guarda do Exército dos Estados Unidos.

www.apoteose.com

compositoresdaportela.blogspot.com

daniellathompson.com

www.dicionariompb.com.br. Dicionário Cravo Albin da Música Popular Brasileira on-line. 
www.folha.uol.com.br.

www.globo.com

www.gresportela.com.br

www.imperatrizleopoldinense.com.br

www.imperioserrano.com

liesa.globo.com. Liga Independente das Escolas de Samba do Rio de Janeiro.

maps.google.com.br. Google Maps.

www.neilopes.blogger.com.br. Meu Lote, blog do compositor e pesquisador Nei Lopes.

www.opandeiro.net. Portal do Professor Marcos Alvito.

osamba.net. Jornal O samba é meu dom.

pratoefaca.blogspot.com. Blog especializado em samba.

www.portelaweb.com

www.samba-choro.com.br

www.sambaderaiz.net. Acervo de álbuns de samba disponíveis para audição on-line.

www.sambariocarnaval.com. Acervo de sambas-enredo on-line, com discografia desde 1968.

socandeia.blogspot.com. Blog dedicado à memória de Antônio Candeia Filho.

\section{Entrevistas}

ÁUREA MARIA. Áurea Maria de Almeida Andrade. Velha Guarda da Portela. Entrevista realizada em 27 de julho de 2010, Rio de Janeiro/RJ.

BALBINA. Balbina de Oliveira Thomé. Velha Guarda do Império Serrano. Entrevista realizada em 21 de julho de 2010, Rio de Janeiro/RJ.

CARLOS MONTE. Diretor Cultural da Portela. Entrevista realizada em 19 de julho de 2010, Rio de Janeiro/RJ.

IVAN MILANEZ. Velha Guarda do Império Serrano. Entrevista realizada em 2 de fevereiro de 2010, Rio de Janeiro/RJ.

LINDOMAR. Lindomar Ferreira Fraga. Velha Guarda do Império Serrano. Entrevista realizada em 27 de julho de 2010, Rio de Janeiro/RJ.

MONARCO. Hildemar Diniz. Velha Guarda da Portela. Entrevista realizada em 29 de janeiro de 2010, Rio de Janeiro/RJ.

NOCA DA PORTELA. Oswaldo Alves Pereira. Compositor da Portela. Entrevista realizada em 29 de janeiro de 2010, Rio de Janeiro/RJ.

SERGINHO PROCÓPIO. Sérgio Procópio da Silva. Velha Guarda da Portela. Entrevista realizada em 20 de julho de 2010, Rio de Janeiro/RJ.

TIA SURICA. Iranette Ferreira Barcellos. Velha Guarda da Portela. Entrevista realizada em 19 de julho de 2010, Rio de Janeiro/RJ.

WILSON DAS NEVES. Velha Guarda do Império Serrano. Entrevista realizada em 11 de outubro de 2009, Rio de Janeiro/RJ.

ZÉ KATIMBA. José Inácio dos Santos. Compositor da Imperatriz Leopoldinense. Entrevista realizada em 9 de maio de 2009, Niterói/RJ.

ZÉ LUIZ DO IMPÉRIO. José Luiz Costa Ferreira. Compositor do Império Serrano. Entrevista realizada em 17 de julho de 2010, Rio de Janeiro/RJ. 


\section{ANEXO - Vozes registradas (roteiro para escutas)}

Abaixo estão listados os sambas e trechos das entrevistas que foram compilados no CD anexo, permitindo uma escuta direta dos sons gravados que originaram algumas das questões principais expostas ao longo desta dissertação.

1. Velha Guarda, de Dicró e Pongá. Faixa 3 do álbum Dicró no Piscinão (2002). [Observar as falas que servem de contextualização, no início e no fim]

2. Homenagem à Velha Guarda da Portela, de Monarco. Faixa 1 do álbum Terreiro (1980).

3. Para o bem do nosso bem, de Alvaiade. Trecho da faixa 2 do álbum Grandes Sambistas: Velha Guarda da Portela (1986), com o comentário final de Casquinha.

4. O samba nunca foi de arruaça, de Monarco e Ratinho. Faixa 11 do álbum Samba pras moças (1995).

5. Menino de 47, de Molequinho e Nilton Campolino. Faixa 2 do álbum Um show de Velha Guarda (2006).

6. Meu lugar, de Arlindo Cruz e Mauro Diniz. Faixa 1 do álbum Sambista perfeito (2007).

7. O meu nome já cain no esquecimento, de Paulo da Portela. Trecho da faixa 6 do álbum Homenagem a Paulo da Portela (1988), com o comentário final de Monarco, seguido da "resposta musical" cantada por ele na entrevista.

8. Nosso nome: resistência, de Nei Lopes, Sereno e Zé Luiz do Império. Faixa 1 do álbum Zumbi - 300 anos canto Banto (1996).

9. Coração em Desalinho, de Monarco e Ratinho. Trecho da entrevista de Monarco.

10. Monarco. Trecho da entrevista.

11. Serginho Procópio. Trechos da entrevista.

12. Esta Melodia, de Bubú da Portela e Jamelão. Serginho Procópio cantando na entrevista e gravação dos Mensageiros do Samba da Portela na faixa 1 do álbum $A$ vez do samba (1966).

13. Surica. Trechos da entrevista.

14. Áurea Maria. Trechos da entrevista.

15. O samba é meu dom, de Wilson das Neves e Paulo César Pinheiro. Faixa 1 do álbum $O$ som sagrado de Wilson das Neves (1996).

16. Wilson das Neves. Trechos da entrevista.

17. Ivan Milanez. Trechos da entrevista.

18. Lindomar. Trechos da entrevista.

19. Balbina. Trechos da entrevista.

20. Sambas de deboche e samba-enredo da Beija-Flor em homenagem a Francisco Alves cantados por Balbina durante a entrevista.

21. Primavera (Cântico à natureza), de Alfredo Português, Jamelão e Nelson Sargento. Balbina cantando durante a entrevista e faixa 7 do álbum Escolas de Samba (1957).

22. Malandros maneiros, de Zé Luiz e Nei Lopes. Faixa 6 do álbum Zé Luiz. (2005). 
23. Zé Luiz. Trechos da entrevista.

24. Mil Réis, de Candeia e Noca da Portela. Trecho da faixa 2 do álbum Axé: gente amiga do samba (1978).

25. Cor da Minha Raça, de Noca da Portela, Toninho Nascimento e Tranka. Noca da Portela cantando na entrevista e trecho da faixa 3 do álbum Uma festa no samba (1997).

26. Zé Katimba. Trechos da entrevista.

27. Na minha veia, de Zé Katimba e Martinho da Vila. Zé Katimba cantando e trecho da faixa 4 do CD Na veia (2009). 